\title{
A Study of Best Practices for the Recruitment and Retention of Resident Directors
}

\author{
Patricia L. Cendana \\ West Virginia University
}

Follow this and additional works at: https://researchrepository.wvu.edu/etd

\section{Recommended Citation}

Cendana, Patricia L., "A Study of Best Practices for the Recruitment and Retention of Resident Directors" (2012). Graduate Theses, Dissertations, and Problem Reports. 274.

https://researchrepository.wvu.edu/etd/274

This Dissertation is protected by copyright and/or related rights. It has been brought to you by the The Research Repository @ WVU with permission from the rights-holder(s). You are free to use this Dissertation in any way that is permitted by the copyright and related rights legislation that applies to your use. For other uses you must obtain permission from the rights-holder(s) directly, unless additional rights are indicated by a Creative Commons license in the record and/ or on the work itself. This Dissertation has been accepted for inclusion in WVU Graduate Theses, Dissertations, and Problem Reports collection by an authorized administrator of The Research Repository @ WVU.

For more information, please contact researchrepository@mail.wvu.edu. 


\section{A Study of Best Practices for the Recruitment and Retention}

of Resident Directors

\section{Patricia L. Cendana}

Dissertation submitted to the College of Human Resources and Education at West Virginia University in partial fulfillment of the requirements

for the degree of

\section{Doctor of Education}

in

Educational Leadership

Joy Faini Saab, Ed.D., Chair

Russell K. Dean, Ph.D.

Ernest R. Goeres, Ph.D.

Christopher L. Plein, Ph.D.

Richard T. Walls, Ph.D.

Department of Educational Leadership Studies

\section{Morgantown, West Virginia}

July 2012

Key words: Resident Director, Recruitment, Retention, Residence Hall

Copyright 2012 Patricia L. Cendana 


\section{ABSTRACT \\ A Study of Best Practices for the Recruitment and Retention of Resident Directors}

\section{Patricia L. Cendana}

A resident director is an entry-level, student affairs professional staff member that resides within a college or university residence hall. The resident director provides developmental experiences for students who live in on-campus housing. The resident director interacts with students around the clock throughout the semester. Unlike other entry-level professional staff, who return to the sanctity of their home at the end of the work day, the resident director's responsibilities for the welfare of their students do not end until the semester is over and the students have moved out. Resident directors assume responsibility for insuring that all residential needs, in terms of quality of life in a college or university residence hall, are fulfilled. They make sure that the residence hall environment is conducive to academic success. They are responsible for ensuring that the residence hall experience is a positive one that contributes to the personal growth of the students.

College and university residence life programs employ the greatest number of entry-level student affairs professionals, which includes resident directors. Success for these young professionals early in their career increases the likelihood of later career success (Collins \& Hirt, 2006). However, the burnout rate of housing staff members is unusually high. "There is a growing concern at many institutions that recruiting and retaining entry-level housing staff has become an overwhelming challenge" (St. Onge, Ellett, \& Nestor, 2008, p. 11-12). This challenge has been described as a crisis that is complicated by high attrition rates (Jones, 2002). Attention to factors that affect the level of preparation with the resident director position may improve their sustainability and overall job satisfaction.

The purpose of this research study was to determine best practices for ensuring that newly hired, entry-level resident directors were sufficiently prepared to assume and retain their crucial leadership role. "Recruitment and retention of competent, if not excellent, housing and residential life staff are essential to our success as professionals and as a profession" (St. Onge, Ellett, \& Nestor, 2008, p. 11). This study examined the hiring qualification and training at 18 institutions. This study also reviewed factors within the 18 institutions' organizational culture that contributed to the retention of the resident directors.

The researcher developed two separate survey instruments, one for resident directors and one for residence life administrators. Survey Monkey ${ }^{\mathrm{TM}}$ was used to survey the resident directors and residence life administrators at the 18 institutions. A total of 148 responses were collected. Percentages were calculated and descriptive statistics were utilized to analyze the data.

The results of this study will inform residence life administrators about appropriate hiring requirements, necessary training topics, and the level of on-going institutional support needed to retain high-quality resident directors. This study will also assist higher education administrators gain a better understanding of the resident director position and residence life profession. 


\section{DEDICATION}

This paper is dedicated to my editor, my husband, and most of all, my BEST friend and soul mate Brett. He spent countless hours reading my work, improving it, and even arguing with me over how things should be written... he usually won the battle. The phrase "That does not sound like doctorate level work" was often used when he could tell my writing was declining, usually because I had written when I was too tired. He also knew the way to calm me down when I would get agitated, such as the time I kept submitting the IRB paperwork and it would not go through, or the time I forgot to save some work and the laptop battery died. I know, I know... "Save, Save, Save." Thank you, thank you, for the countless hours you invested in this work and all the other papers I've written for classes throughout my educational career. I certainly couldn't have done it without you and I certainly wouldn't have remained somewhat sane without you.

This success is yours as much as it is mine.

We shall share in it together!

Thank you for everything.

Lave Ya, Trish 


\section{Acknowledgements}

First, I must acknowledge the most important people in my life - my family. My loving husband Brett, who has stood by my side through all of the hard work, long nights, and frustrating times while remaining upbeat, supportive, and dedicated to helping me achieve this goal. My wonderful children Christina, Drew, and Stephanie, who were, and continue to be the driving force in me to make changes in my life, to improve myself so that I can make a better life for all of us. My son-in-law Chris, my granddaughter Jazzy (whom everyone knows is “grammy's girl") my new grandchild on the way, my step-daughters Maria and Jessie, who are all Gods bestowed blessings to our loving family. My sister Joy and brother Mark, whom I have always relied upon for sibling advice and guidance. My mother Pauline, father Bob, step-mother Joan, and in-laws June and Elena who gave me a wonderful family foundation. Thank you ALL for being there for me, for being supportive, for giving up "wife", "mom", "sis", "daughter", and "grammy" time so I could study. I love all of you dearly!!

I would also like to thank my committee members Dr. Russell Dean, Dr. Ernest Goeres, Dr. Chris Plein, and Dr. Walls who provided excellent advice and guidance. Without your support, encouragement, mentorship, and signatures :) this dream couldn't have been possible. Special thanks to my chairs who kept me on track and focused. Dr. Elizabeth Jones, for helping me defend the prospectus and Dr. Joy Saab for agreeing to serve as chair at the last minute and assisting me with reaching my final defense. I owe a debt of gratitude to all of you for your time, service, and devotion to my success.

To all the faculty at WVU who are more than just a lecturer. Those that specifically challenged me \& gave me the needed educational preparation to pursue doctorate-level work. Dr. Mohamad Alkadry, Dr. Susan Aloi, Dr. Sebastian Diaz, Dr. Ernest Goeres, Dr. Daniel McNeil, Dr. Richard Hartnett, Dr. Elizabeth Jones, Dr. Chris Plein, Dr. Gerald Pops, Dr. Richard Walls \& Dr. David Williams, thank you for your dedication to helping students, like me, succeed.

To my mentors in the Provost Office who started me on the road to educational success, Dr. Russell Dean and Dr. Nancy Lohmann. You had faith in me succeeding from the day I started working for you both in 1993 (yes, that long ago). You were always so supportive of my educational endeavors. Your leadership, professionalism, and dedication to helping people succeed always inspired me and continue to do so to this day. I must also mention former WVU President David Hardesty, who always prodded me to complete my Masters in time for him to sign my diploma. Every time I see him he asks how I'm progressing towards being a "doc."

To all the resident directors and residence life staff members who work tireless hours, not because they have to, but because they genuinely care and want to make a difference in our young students' lives. An extra special thanks to those who took time out of their busy schedule to participate in the study. I'm proud to be in the field with so many dedicated people. People like you and all the other silent heroes ....those who receive their rewards in life through others' success. You know who you are!

Finally, to God for the blessings you have bestowed upon me and my family. I hope I can use the experience I have gained throughout the years to help others achieve their success as well. 


\section{Table of Contents}

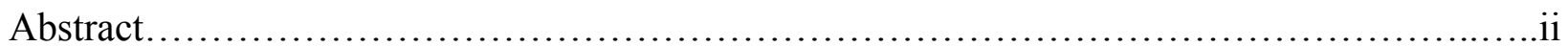

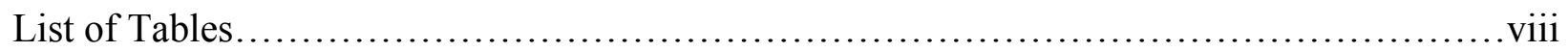

Chapter One - Introduction to the Study............................................

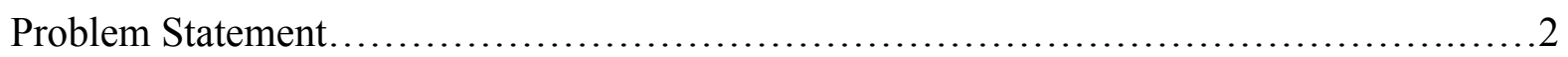

Purpose of the Study ............................................................

Research Questions..............................................................

Significance of the Study.....................................................

Organization of the Dissertation.............................................. 8

Chapter Two - Literature Review............................................. 10

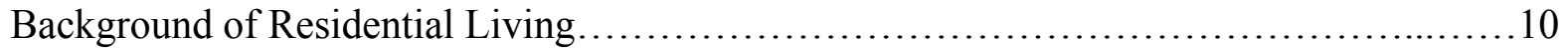

Importance of Resident Director............................................ 14

Level of Preparation........................................................ 19

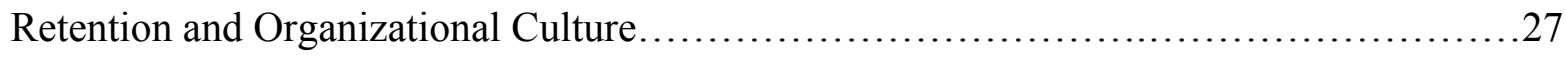

Summary of Literature Review............................................. 31

Key Terms and Concepts...................................................... 32

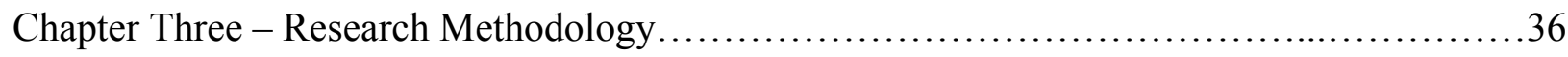

Research Design........................................................... 37

Site Selection and Institutional Profile........................................... 38

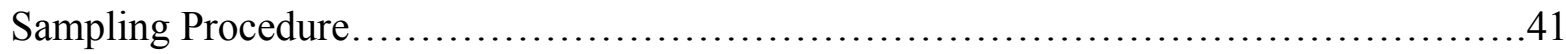

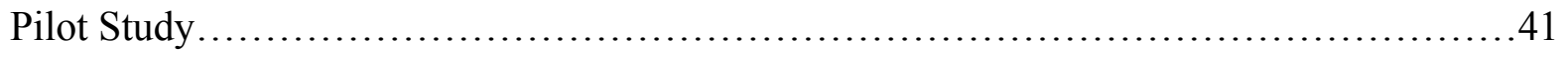

Data Collection and Survey Instruments........................................43

Methods of Data Analysis...................................................... 44 


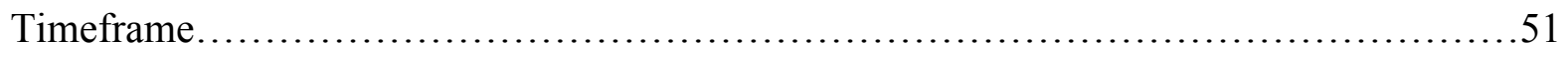

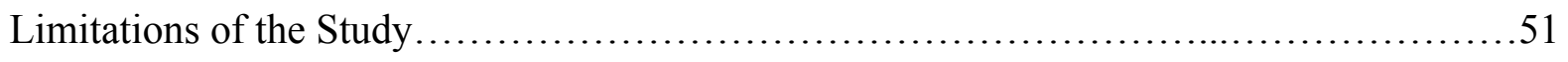

Background of the Researcher.................................................... 52

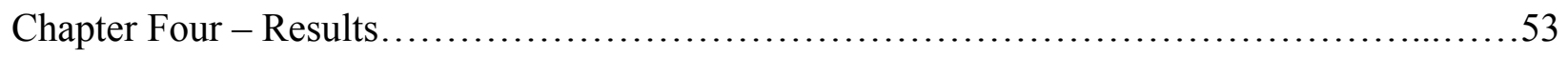

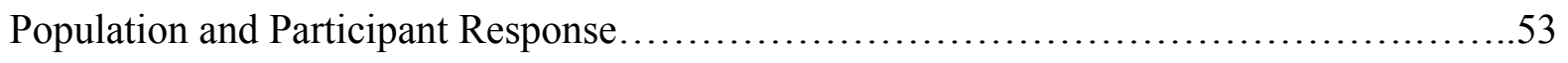

Demographics and Participant Information...........................................53

Research Questions One and Three - Comparison of Level of Preparation..................67

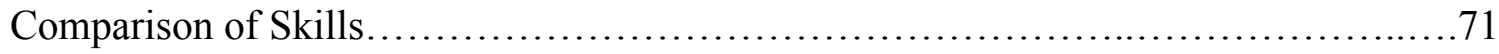

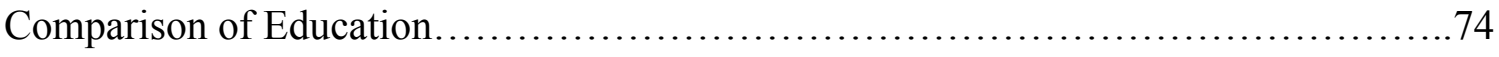

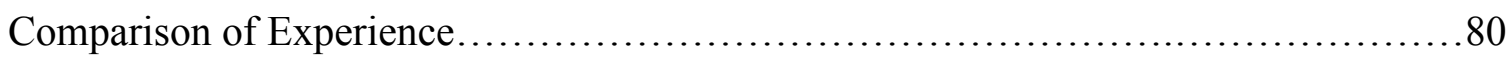

Research Questions One and Three - Comparison of Training............................8 87

Research Questions Two and Three - Comparison of Resident Directors' Retention and

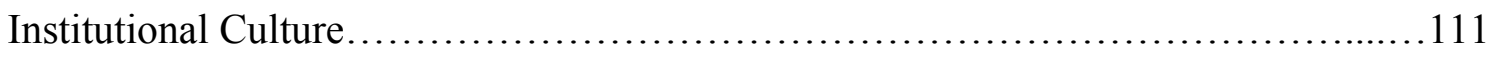

Comparison of Professional Development.........................................128

Comparison of Professional Mentors...........................................133

Comparison of Rewards and Benefits.............................................139

Chapter Five - Summary and Recommendations...................................... 155

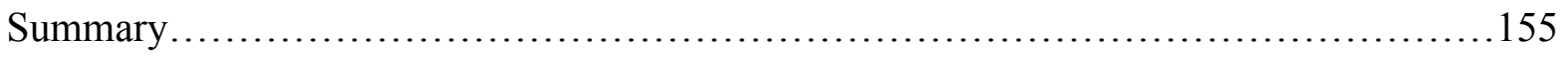

Participant and Institutional Background Information................................ 155

Level of Preparation............................................................ 157

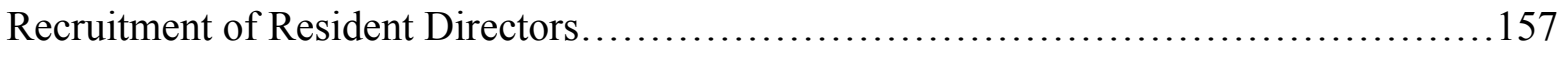

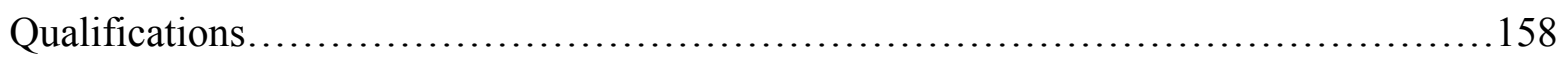

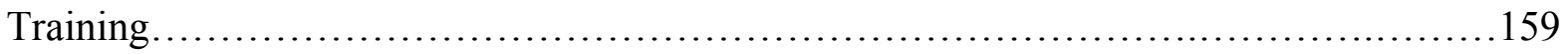


Retention and Organizational Culture ............................................ 160

Comparison of HEPC and ACUHO-I Institutions......................................164

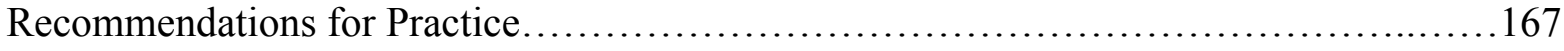

Recommendations for Future Research..........................................171

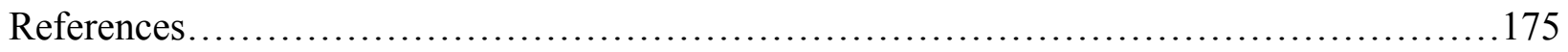

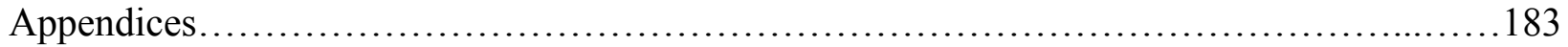

Appendix A- Resident Director Survey ........................................... 187

Appendix B - Residence Life Administrators Survey...................................204

Appendix C - Pilot Invitation Letter..................................................226

Appendix D - Participant Invitation Letter.........................................228 


\section{List of Tables}

Table 1 Institutional Profile of ACUHO-I Best Practice Institutions..........................39

Table 2 Institutional Profile of Selected WVU's HEPC Peer Institutions........................40

Table 3 Resident Directors ' Survey-Research Questions \& Corresponding Survey Questions...49

Table 4 Administrators' Survey-Research Questions \& Corresponding Survey Questions.........50

Table 5 Population and Respondents of HEPC and ACUHO-I Institutions ........................54

Table 6 Gender of Resident Director Participants ............................................54

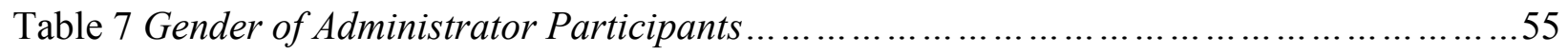

Table 8 Age of Resident Director Participants ..............................................55

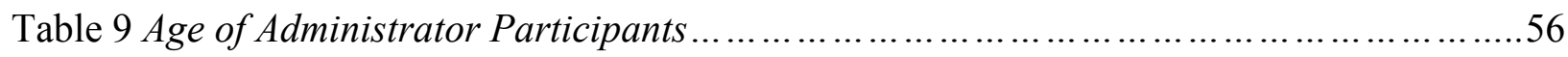

Table 10 Ethnic Affiliation of Resident Director Participants .................................57

Table 11 Ethnic Affiliation of Administrator Participants .....................................58

Table 12 Live-In Spouse or Partner Status .........................................................59

Table 13 Resident Director Survey Participant Titles .........................................59

Table 14 Administrator Survey Participant Titles..........................................60

Table 15 Participants Years as a Resident Director............................................61

Table 16 Participants Years as a Residence Life Administrator................................662

Table 17 Participants Years as a Resident Director at Current Institution.........................63

Table 18 Participants Years as a Residence Life Administrator at Current Institution............63

Table 19 Academic Class Rank of Students in the Residence Halls ................................64

Table 20 Gender of Residence Hall Students .............................................6 65

Table 21 Resident Directors' Responsibilities ...............................................66

Table 22 Number of Resident Assistants Supervised by Resident Directors.......................67 
Table 23 Resident Directors' Rating of Level of Preparation First Hired ...........................68

Table 24 Administrators' Rating of Level of Preparation of Resident Director First Hired......69

Table 25 Resident Directors ' Rating of Current Level of Preparation ..............................69

Table 26 Administrators' Rating of RDs Level of Preparation One Year or More Experience ...70

Table 27 HEPC \& ACUHO-I Resident Directors' Rating of Level of Importance of Skills........71

Table 28 HEPC Resident Directors' Rating of Level of Importance of Skills ......................72

Table 29 ACUHO-I Resident Directors' Rating of Level of Importance of Skills..................73

Table 30 Administrators' Rating of Level of Importance of Skills .................................74

Table 31 Resident Directors Current Level of Education .................................... 75

Table 32 Resident Directors 'Level of Education When First Hired.................................75

Table 33 Resident Directors Enrolled in Degree Program ......................................76

Table 34 Degree Program Resident Directors Currently Enrolled In .............................77

Table 35 Resident Directors' Plan to Enroll in Degree Program in Near Future...................77

Table 36 Degree Programs Resident Directors Plan to Enroll in Near Future.....................78

Table 37 Minimum Level of Education Required for Resident Directors...........................79

Table 38 Administrators' Ability to Hire Candidates Who Meet Minimum Educational

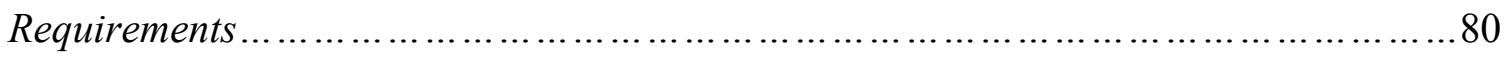

Table 39 Resident Assistant Experience Required ............................................. 79

Table 40 Years of Resident Assistant Experience Required ....................................... 81

Table 41 Resident Assistant Experience of Resident Directors ...............................82

Table 42 Years of Resident Assistant Experience held by Resident Directors......................82

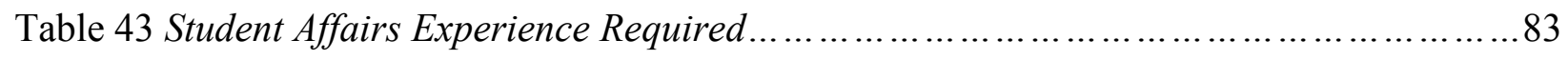

Table 44 Years of Student Affairs Experience Required ..........................................8 
Table 45 Resident Directors' Student Affairs Experience.... 85

Table 46 Years of Student Affairs Experience held by Resident

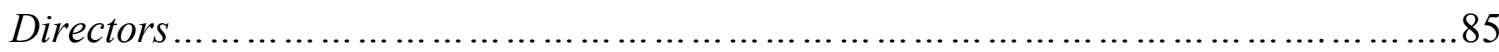

Table 47 Administrators' Ability to Hire High Quality Resident Directors..........................86

Table 48 Advertisement and Recruitment Methods Utilized by Administrators......................87

Table 49 Number of Days Resident Directors Assumed Duties Prior to Academic Year...........88

Table 50 Number of Days Resident Directors Typically Assumed Duties Prior to Academic

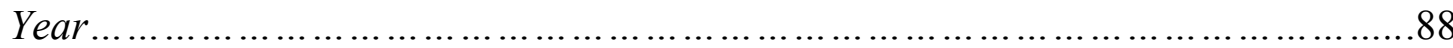

Table $511^{\text {st }}$ Year Resident Directors that Participated in Training Before Halls Opened..........89

Table 52 Administrators who Provided $1^{\text {st }}$ Year RD Training Before Halls Opened................90

Table 53 Length of $1^{\text {st }}$ Year Resident Director Training Before Halls Opened ......................90

Table 54 Length of $1^{\text {st }}$ Year RD Training Before Halls Opened Reported by Administrator.......91

Table 55 Topics Covered in $1^{\text {st }}$ Year Training Before Halls Opened...............................92

Table 56 Topics Covered in $1^{\text {st }}$ Year Training Before Halls Opened Reported by

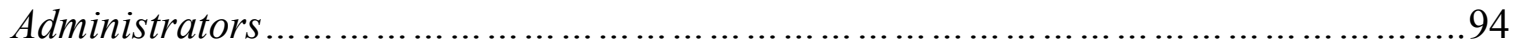

Table 57 Resident Directors' Rating of $1^{\text {st }}$ Year Training Before Hall Opened.......................95

Table 58 Resident Directors ' Comments on Why $1^{\text {st }}$ Year Training Not Valuable..................95

Table 59 Administrators' Rating of $1^{\text {st }}$ Year Resident Director Training Before Halls

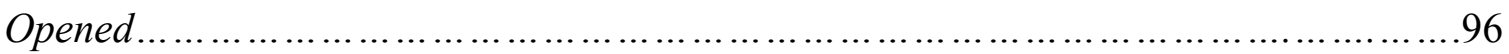

Table 60 Administrators' Comments on Why $1^{\text {st }}$ Year Training Not Valuable.......................96

Table 61 Resident Directors Provided with Training After Halls Opened ...........................97

Table 62 If No Training Provided, Resident Directors Felt Additional Training Valuable.........98

Table 63 Administrators who Provided RDs with Training After Halls Opened ....................98 
Table 64 Topics Covered in Training After Residence Halls Opened....

Table 65 Topics Covered in Training After Residence Halls Open Reported by

Administrators 100

Table 66 Resident Directors ' Rating of $1^{\text {st }}$ Year Training After Halls Opened.

Table 67 Resident Directors' Comments on Why Training After Halls Opened Was Not

Valuable....

Table 68 Administrators' Rating of Resident Director Training After Halls Opened..............103

Table 69 Resident Directors Required to Participate in Training on Regular Basis............103

Table 70 Administrators who Required RDs to Participate in Training on Regular

Basis....

Table 71 Frequency of Formal Training Provided on Regular Basis

Table 72 Frequency of Formal Training Provided on Regular Basis Reported by

Administrators 106

Table 73 Resident Directors who Felt Appropriately Trained to Handle

Responsibilities..... 106

Table 74 Administrators who Felt RDs Appropriately Trained to Handle Responsibilities. 107

Table 75 Topics in Which Resident Directors Felt Additional Training Needed..... 108

Table 76 Topics in Which Administrators Felt Additional Training Needed.

Table 77 Resident Directors ' Additional Comments Related to Recruitment or Training.........110

Table 78 Administrators' Additional Comments Related to Recruitment or Training..............111

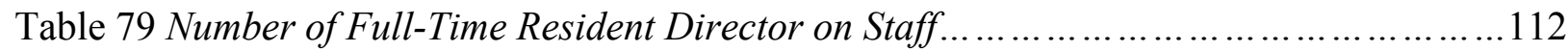

Table 80 Years of Experience of Resident Directors on Staff .................................. 112

Table 81 Likeliness of Resident Directors to Continue Next Year at Current Institution.... 
Table 82 Years Resident Directors Plan to Continue at Current Institution 114

Table 83 HEPC Administrators' Likelihood Rating of RDs to Remain at Current Institution ...115

Table 84 ACUHO-I Administrators' Likelihood Rating of RDs to Remain at Current

Institution

Table 85 Likeliness of Resident Directors to Continue as RD at Another Institution................116

Table 86 HEPC Resident Directors' Rating of Reasons Likely to Leave RD Position..............117

Table 87 ACUHO-I Resident Directors' Rating of Reasons Likely to Leave RD Position.........117

Table 88 HEPC Administrators' Rating of Common Reasons RD Likely to Leave ...................119

Table 89 ACUHO-I Administrators' Rating of Common Reasons RD Likely to Leave.

Table 90 Degree to Which Resident Directors Felt Respected by Department Administration

Table 91 Degree to Which Administrators Felt RDs Respected by Department Administration 121

Table 92 Degree to Which Resident Directors Felt Respected by University Administration....122 Table 93 Degree to Which Administrators Felt RDs Respected by University Administration..123 Table 94 Degree to Which Resident Directors Felt Valued as a Staff Member 123

Table 95 Degree to Which Administrators Felt RDs Valued as a Staff Member....................124

Table 96 Frequency in Which Resident Directors Provided Performance Feedback...............125

Table 97 Frequency in Which Administrators Provided RDs with Performance Feedback......126

Table 98 Frequency in Which Resident Directors Able to Operate Autonomously ..................127

Table 99 Frequency in Which Administrators Allowed RDs to Operate Autonomously 127

Table 100 Frequency in Which Resident Directors Encouraged to Develop Professionally.....128 Table 101 Frequency in Which Administrators Encouraged RDs to Develop Professionally ... 129 
Table 102 Frequency in Which RDs Participated in Professional Development..................130

Table 103 Types of Professional Development Opportunities Administrators Funded.............131

Table 104 Types of Professional Development Opportunities RDs Participated In............... 132

Table 105 Reasons Why Resident Directors Did Not Participate in Professional

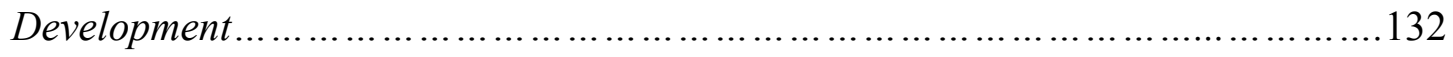

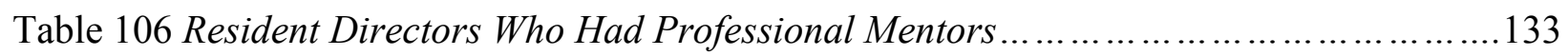

Table 107 Administrators Who Provided Formal Professional Mentor Programs.................134

Table 108 Resident Directors' Classification of Professional Mentors ........................134

Table 109 Administrators' Classification of Professional Mentors ............................ 135

Table 110 RDs Who Felt Having a Professional Mentor Assisted Professional Growth........136

Table 111 Administrators Who Felt Professional Mentors Assisted RDs' Professional

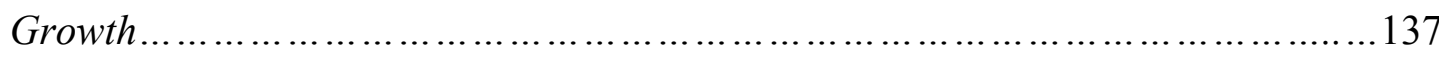

Table 112 Resident Directors' Rating of Benefits of Having a Professional

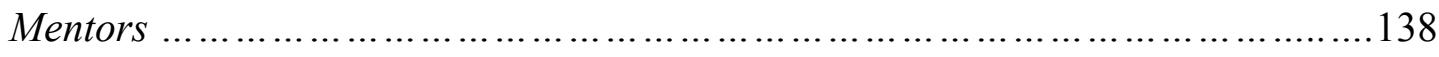

Table 113 Administrators' Ratings of Benefits of Having a Professional Mentor Assigned to

Resident Directors......................................................... 138

Table 114 Resident Directors Required to Live-In Residence Halls .............................. 139

Table 115 Administrators who Required Resident Directors to Live-In Residence

Hall

Table 116 Resident Directors On-Call 24 Hours/7 Days a Week during Academic

Year

Table 117 Administrators who Required RDs On-Call 24 Hours/7 Days a

Week 
Table 118 Resident Directors with Rotating On-Call Schedule for Evening Emergencies

Table 119 Administrators Who Provided Rotating On-Call Schedule for Evening

Emergencies.

Table 120 HEPC Resident Directors' Rating of Importance of Rewards and Benefits.... 143

Table 121 ACUHO-I Resident Directors' Rating of Importance of Rewards and Benefits.......144

Table 122 HEPC Administrators' Rating of Rewards and Benefits..... .145

Table 123 ACUHO-I Administrators' Rating of Rewards and Benefits..... 146

Table 124 HEPC Resident Directors' Satisfaction with Rewards and Benefits.....

Table 125 ACUHO-I Resident Directors' Satisfaction with Rewards and Benefits.... .148

Table 126 HEPC Administrators' Satisfaction with Rewards and Benefits

Table 127 ACUHO-I Administrators' Satisfaction with Rewards and Benefits.... 150

Table 128 Resident Directors' Comments Related to Resident Director Retention 151

Table 129 Administrators' Comments Related to Resident Director Retention... 152

Table 130 Resident Directors' Comments on Single Most Important Motivating Factor to Work at their institution 153

Table 131 Administrators' Comments on Single Most Important Motivating Factor for RDs to

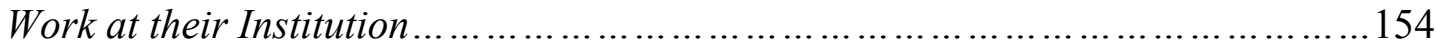

Table 132 Population and Respondents of HEPC and ACUHO-I Institutions......................156

Table 133 Comparison of Institutions..... 


\section{Chapter One}

\section{Introduction}

A resident director is contacted by a distressed parent because she has not been able to reach her son after calling him several times. Her son normally calls home every morning before he leaves the residence hall to attend class. The parent is extremely worried because the student's behavior has not been typical lately. The parent explains that just the night before, her son had called saying that he felt lost and alone. The parent also explains that her son has not been doing well in classes, appears to be depressed, and seems disengaged. The parent informs the resident director that she logged onto her son's Facebook page a few minutes ago and found discussions posted to the site that were disturbing in nature; one posting referred to him ending his life. The parent expresses concern to the resident director about her son's safety.

The resident director attempts to calm the parent, explaining that her son probably just over-slept, but assures the parent that they will go to the room and check on her son immediately. The resident director knocks on the student's room door several times; there is no response. Given the situation the parent described, the resident director makes a judgment call and keys into the student's room. The resident director sees the student in the room spread out on the floor unconscious, vomit all over the floor, a bottle of antifreeze next to the bed. The resident director calls 911 , just in time to save the student's life.

In this realistic scenario, one might question whether newly hired resident directors would be prepared to handle this type of crisis situation. Although training outlines the appropriate procedures for dealing with the immediate crisis, no one can predict how they will react until the situation presents itself. Resident directors must be able to remain calm so that can effectively manage the crisis at hand. They must also be able to maintain their own personal 
well-being so that they can perform well on the job. This research study will examine what it takes to insure that newly hired resident directors are properly trained and prepared to effectively cope with the many crisis situations that they will encounter.

\section{Problem Statement}

A resident director is an entry-level, student affairs professional staff member that resides within a college or university residence hall. The resident director position is known by various titles; however their responsibilities and duties are generally the same. Some examples of the different titles utilized include: Residence Hall Director, Residence Life Coordinator, Community Coordinator, and Residence Hall Coordinator. For the purposes of this research study, the term Resident Director (RD) will be utilized.

The resident director provides developmental experiences for students who live in oncampus housing. The resident director is responsible for the management and daily operations of the residence halls, and the overall well-being and care of students residing in the hall. The resident director interacts with students around the clock throughout the semester. Unlike other entry-level professional staff, who return to the sanctity of their home at the end of the work day, the resident director's responsibilities for the welfare of their students do not end until the semester is over and the students have moved out. Even throughout the summer, there are many administrative tasks that a resident director must coordinate to prepare for the next incoming class of residence life students.

The duties of a resident director are numerous and diverse. One of the main responsibilities of the resident director is to supervise several student staff members called resident assistants (RAs). Depending on the institution, they could also have supervisory responsibilities for other para-professional or professional staff members such as office 
assistants, desk staff, custodians, night staff, and secretaries. Resident directors advise residence hall councils and other student groups or organizations; they also serve as instructors for different type of classes (i.e. Academic, Stress and Time Management Skills, First-Year Experience, and Resident Assistant Seminars). Resident directors assume responsibility for insuring that all residential needs, in terms of quality of life in a college or university residence hall, are fulfilled. They make sure that their residence hall environment is conducive to academic success.

Resident directors also oversee the residence hall judicial process, making sure that students adhere to all policies and procedures of the hall and the institution. The resident director also counsels students on behavioral matters. Depending upon the institution, they may serve as a hearing officer that adjudicates cases and sanctions students when their behavior warrants discipline. They are responsible for ensuring that the residence hall experience is a positive one that contributes to the personal growth of the students.

College and university residence life programs employ the greatest number of entry-level student affairs professionals, which includes resident directors. Success for these young professionals early in their career increases the likelihood of later career success (Collins \& Hirt, 2006). However, the burnout rate of housing staff members is unusually high. "There is a growing concern at many institutions that recruiting and retaining entry-level housing staff has become an overwhelming challenge" (St. Onge, Ellett, \& Nestor, 2008, p. 11-12). This challenge has been described as a crisis that is complicated by high attrition rates (Jones, 2002). "According to studies of housing professionals, attrition is an important issue; research has reported an attrition rate as high as 61\%” (Dunkel \& Schreiber, 1992, p. 22). Attention to factors that affect the level of preparation with the resident director position may improve their 
sustainability and overall job satisfaction. Understanding elements that contribute to residence life professionals' employment satisfaction can improve the likelihood of job retention (Jones, 2002).

In order to grasp the issues that cause attrition in a twenty-four hour, seven day a week leadership position, it is crucial to understand the demands and the work environment of a newly hired resident director. However, understanding the unique work environment of resident director is difficult for those who do not work in residence life (Collins \& Hirt, 2006). The professional lives of student affairs administrators are affected by their work conditions and opportunities for career advancement (Solomon \& Tierney, 1977). Additionally, physical and psychological stress influence satisfaction with work life (Anderson, et al. 2000; Berwick, 1992, Work, 1995). Sandeen \& Barr (2006) in the book Critical Issues for Student Affairs, wrote: Employment in student affairs sometime represents less than ideal working conditions. Long hours, high expectations for availability to students, a volatile environment, turnover of students.... make stability and predictability difficult to achieve. In addition, normal organizational pressure makes new professional experience challenging at best. (p.72)

To excel in this type of environment the resident director must be well prepared. "The recruitment, retention, development, and advancement of entry-level professionals are critical to any organization" (St. Ogne, Nestor, \& Ellett, 2008, p. 22). Hiring high-quality candidates, training, and on-going institutional support are factors that directly contribute to the resident director's level of preparation, as well as their ability to succeed in their position. "Recruitment and retention of competent, if not excellent, housing and residential life staff are essential to our success as professionals and as a profession" (St. Onge, Ellett, \& Nestor, 2008, p. 11). Although 
it is evident that recruitment and retention is paramount to the success of entry level professionals, colleges and universities utilize a wide-range of hiring qualifications, training techniques, and levels of institutional support for the resident director positions.

Qualifications. While many entry-level professional positions require comparable hiring requirements for similar positions, this is not necessarily the case for the resident director position. "A review of existing literature has yielded a long and varied list of skills and competencies identified as important for work in higher education" (Wright \& Miller, 2007, p. 125). Although not universal, most universities require the resident directors to have at the minimum of a Bachelor's Degree. The most common profile shows that $57.6 \%$ of entry-level housing staff living in a residence hall completed their bachelor's degree (St. Onge, Ellett \& Nestor, 2008). Other institutions require a Master's Degree in a specific field, such as college student personnel, higher education, or another related or relevant field. On the other end of the spectrum, some institutions fill the resident director positions with part-time graduate students and a small number of institutions hire undergraduate students to fill this important role (Horowitz, 2009).

Residence hall experience is also another fluctuating qualification factor for institutions. Irby (2000) stated that "the traditional credentials of the academy - baccalaureate and graduate degree no longer suffice. Additional specializations, demonstrated knowledge, and job-relevant know how have increasing currency in the work place" (Wright \& Miller, 2007, p. 152). Some institutions require their resident directors to have residence assistant experience, while others do not require it.

Training. Since institutions have varying hiring requirements, it is important to determine what role training plays in ensuring that resident directors are adequately prepared. In 
addition to operational training, resident directors are often trained in counseling, safety and security, student development, student conduct, and emergency response. While most resident life programs offer extensive training for their staff (Dunken \& Schreiber, 1992), it may not be sufficient, especially for institutions whose resident hall directors' qualifications are minimal.

Institutional Support. "Many entering the work in higher education have found themselves in unstable, confusing and conflicting work environments. Some have suggested that preparation for work in higher education is a career-long process and that one never stops preparing professionally" (Wright \& Miller, 2007, p. 124). "The institutional climate contributes to the continuing development and retention of newly hired Resident Directors. Retention rates for residence life professionals may be enhanced by promoting and developing cross-campus relations through staff development activities" (Collins \& Hirt, 2006, p. 22). Support from administration, formal and informal mentor programs, professional development opportunities, rewards and benefits are factors that vary across institutions. These factors should be researched to determine how instrumental they are in preparing and retaining newly hired resident directors.

\section{Purpose of the Study}

The purpose of this research study is to determine best practices for ensuring that newly hired, entry-level resident directors are sufficiently prepared to assume and retain this crucial leadership role. The fact that institutions are so diverse in their qualifications for the resident director position poses questions about the appropriate level of preparation these new professionals have obtained through their previous educational experiences, or will receive through additional training or professional development opportunities. It is also extremely difficult to replace a resident director, particularly mid-semester. Once hired and trained, it is 
important to retain high quality resident directors. On-going institutional support plays a critical role in ensuring that resident directors flourish and thrive in their new role.

This research study will examine the hiring qualifications and training at 18 institutions; 11 identified by an Association of College \& University Housing Officer - International (ACUHO-I) Commissioned Research Program (Ellett, et. al., 2008) as having best practices in the recruitment and/or retention of resident directors and seven institutions selected from West Virginia University's (WVU) Higher Education Policy Commission (HEPC) peer institutions. This study will also look at factors within these institutions' organizational culture that contribute to the retention of resident directors.

\section{Research Questions}

1. How well prepared are resident directors to assume their demanding leadership role?

a. What qualifications (skills, education, and experience) do institutions require for resident directors?

b. What types of training are resident directors provided?

2. How likely is a resident director to be retained based on the institution's organizational culture?

a. What types of professional development opportunities exist?

b. What type of mentoring occurs?

c. What types of rewards and benefits are offered?

3. How do recruitment and retention practices at ACUHO-I best practice institutions compare to those at WVU's HEPC peer institutions? 


\section{Significance of the Study}

The resident director is a professional student affairs staff member that helps students get acclimated during their first-year of college. "They are significant influences for the education, leadership, and management of residence halls, whether in large systems or small, public or private" (St. Onge, Ellett, Nestor, 2008, p. 11). Their position is critical in helping students succeed in their college career. They must be well prepared to take on this role. This research study will assist residence life administrators, who hire and train resident directors, ensure that the resident directors are well prepared to assume their role and succeed in that role. This study will inform residence life administrators about appropriate hiring requirements, necessary training techniques, and the level of on-going support needed to retain high-quality resident directors.

Very few educators outside of residence life understand the complexities of residence life staff duties and the significance of their position. This study will also assist higher education administrators gain a better understanding of the resident director position, the level of preparation of the people who remain in the position, and factors that cause resident directors to leave their position. This study will add to the research base of what is known about this professional population in terms of their level of satisfaction, burnout, and their intent to leave their position by examining factors relating to the recruitment and retention of resident directors.

\section{Organization of the Dissertation}

The remainder of this research study is organized into five chapters, accompanied by a bibliography and appendices. Chapter Two, the literature review, represents an analytical discussion of relevant literature dealing with evolving trends in recruitment and retention of student affairs leadership positions, specifically resident directors. Chapter Two is comprised of 
five major sections. The first section of the chapter provides a background of residential living. The second section of the chapter describes the importance of the resident director. The third section of the chapter outlines factors associated with the resident directors' level of preparation. The fourth section of the chapter describes factors associated with retention and organizational culture. The final section provides a summary and defines key terms and concepts as revealed in the literature. Chapter Three provides and describes the rationale for selecting the research design and the limitations of the study. Chapter Three also describes the methodological decisions for the study and instruments used to gather data, factors leading to the selection of the institutions surveyed, institutional approval information, sampling procedures, methods used for attaining participation, data collection, and data analysis. Chapter Four contains an analysis of the data collected. A summary of the findings, conclusions, and recommendations for further research are found in Chapter Five. The survey instruments and appropriate invitations to participate are attached as appendices. 


\section{Chapter Two}

\section{Review of Literature}

\section{Background of Residential Living}

The term "dormitory" or "dorm" comes from the Latin word dormio, meaning "to sleep." Providing a residence for college students has been part of Britain and mainland Europe's higher education institutions' mission for over eight centuries. During the thirteenth century, in Oxford and Cambridge, students took it upon themselves to find lodging. Students found residence in places such as taverns, private homes, hospices, or hostels. Because there was a lack of organized housing options, students' behavior was unsupervised and unruly. University town life typically consisted of riots, disturbances, and other student disciplinary issues. The students' behavior created tension and conflict between the universities and the towns that they were located in.

Between the thirteenth and fourteenth century, universities began to realize that they had to improve their relationship with the town folk and gain control of their students. They began to implement measures to discipline student behavior. Part of those measures included the development of more organized housing facilities that were staffed with head masters or "magistri" to handle student discipline outside the classroom (Silver, 2004). "The thirteenth century also saw the beginning of what was to become known as the college system in England and many other European colleges" (Silver, 2004, p. 124). Even with these efforts in place, as late as the $1800 \mathrm{~s}$, increasing number of critics complained that housing young men together with little academic work and many vices to distract them would lead to their moral decay and rebellion (Palmer, Broido, Campbell, 2008). It was evident that those who coordinated student 
housing needed to provide students with more than a place to sleep. Silver (2004), in the book Residence and Accommodation in Higher Education: Abandoning a Tradition, wrote:

The universities and their constituent colleges aimed to achieve three inter-related aspects of student residential experience: its disciplinary requirements; its relationship to learning procedures, moral and social aspects of living; and therefore the adult characteristics and roles of the elites that were to serve church, state and the professions. (p124)

The importance of integrating learning within the college dormitory environment is not a modern concept. Dating back to the centuries of the Common Era, students were advised to live with each other and with their faculty masters. Moving forward to when the American colonial colleges were formed, students lived together with their faculty masters in more formal housing arrangements known as campus dormitories (Palmer, Broido, \& Campbell, 2008). However, the role of faculty in housing operations changed during the middle of the $20^{\text {th }}$ century when influence from the German college model caused faculty to conduct more research. As the German model became more prevalent in American institutions, faculty involved with dormitory life were eventually required to devote more time to research. This left little time for faculty members, who were traditionally males, to conduct housing operations and to administer student discipline. Housing operations were then taken on by mostly women, known as housemothers, who worked with the deans under a newly formed unit known as student affairs. Until the middle of the $20^{\text {th }}$ century, student affairs live-in staff members served primarily as building managers and student disciplinarians. Most housing staff did not have the educational preparation to integrate living and learning experiences. In fact, many housing staff members did not have degrees themselves (Palmer, Broido, \& Campbell, 2008). 
During the 1950s and 1960s, there was tremendous growth in higher education enrollment, mostly due to veterans and baby-boomers entering college life. This increased the demand for student housing. University administrators realized that the housemothers were not adequately prepared to handle the increased problems that came with the increase enrollment. Administrators also realized the importance of keeping students occupied outside of the classroom. This created a new focus on staff training and residence hall program development. This type of programming would become associated with what is now known as residence life. "As housing systems grew in size and complexity, it became apparent that professionally trained staff were needed in college housing" (Palmer, Broido, \& Campbell, 2008, p. 89). In 1952, the Association of College and University Housing Officers (ACUHO) was formed to help address the need for better trained student affairs housing professionals. During the 1960s, there was a shift from staffing dormitories with housemothers to providing residence halls with paraprofessional and professional residence educators, known today as resident assistants and residence directors (Frederiksen, 1993; Schroeder \& Mable, 1994). The resident directors functioned as more than just a disciplinarian; they were to incorporate educational activities in the dorms to occupy the students' time when they were not in class. They would also serve as the professional person initially responding to student crisis situations in the dorms.

In 1965, the American College Personnel Association in cooperation with ACUHO published a monograph written by Harold Riker, then director of housing at University of Florida, that discussed the need to incorporate programming into the living environment so that the housing could have an educational component. Riker (1965), in the book College Housing as Learning Centers, wrote: 
The educational role in college housing is founded in two very basic, but very important assumptions: (1) Environment influences behavior, and (2) learning is a total process. The interpersonal environment can, likewise, either facilitate learning or, if impoverished, inhibit the education process. (Riker \& Decoster, 2008, p. 81)

Higher education institutions realize more than ever the importance of housing college students together in a common sleeping environment. In fact, many universities and colleges require students, especially freshmen, to reside together in a common area. However the era of "animal house" dormitories, where students simply slept and socialized, are extinct. Over the last fifty years the dormitories have evolved from a sleeping place into a residential community where learning continues beyond the classroom. Riker (1965), in the book College Housing as Learning Centers, wrote:

Living is to be defined as more than a bed and learning as more than desk; they are part of the total process, a wholeness of student experience on the campus. To contribute favorably and consistently to this experience, the living and learning that go on in student housing have to be stimulated and sustained by planned programs. (Riker \& Decoster, 2008, p. 61)

Resident directors have become responsible for planning and developing these programs so that the students' residence hall experience is one that contributes to their overall personal growth and development, as well as their academic success. The traditional dormitories have transitioned into much more than a place to sleep. Even the terminology has changed to reflect the change in culture. Today, students live in residence halls where resident directors provide twenty-four hour management, ensuring that the residence hall environment is conducive to students' academic and personal success. 


\section{Importance of the Resident Director}

While the need to house students is an important function of the residence halls, investing financial resources into residence hall programs, and hiring professional staff members to coordinate these programs, has shown to increase the retention rates of students who live oncampus (Blimling, 1993). Institutional administrators invest in these programs because they know that students' behavior outside of the classroom is very different from their behavior inside the classroom. The immaturity of traditional aged students is often witnessed in the residence halls where many students experience, for the first-time, freedoms not granted under their parents' watchful eye. Residential communities, and the support systems provided within these communities, influence first-year students behavior, learning, and academic success (Astin, 1993; Pascarella \& Terenzing, 1991). Residence life is the core of student affairs, having more opportunities during the first-year of college to influence student development than any other student affairs unit (Bliming, 1993). Resident directors are the heart and soul of the institution's residence life programs, making the resident director one of the most influential people in the lives of first-year college students.

Over the last forty years, housing and residence life programs have achieved several crucial milestones including: a) increased professionalism in the field, b) the creation of standards and guidelines for residence life professional practice, and, c) substantive residence life staff members' professional education (Riker, 1993). "Prior to these changes, first-year student

halls were often viewed as the most difficult and unhealthy environments to manage" (Upcraft, Gardner, Barefoot, et al, 2005, p. 417).

Because the philosophy within residence life has changed to focusing on a holistic approach to student development, it has been important to change the ways residence halls are 
staffed. Professional student affairs staff members have replaced the once traditional housemothers, devoting more time to the transitional needs of the students living in a residence hall community. Resident directors have emerged as the quintessential collaborators in the development of these residence hall communities, engaging students in the entire learning process (Belch \& Muller, 2003). St. Onge, Ellett, \& Nestor indicated that:

Resident directors and other entry-level housing staff are key positions, often having direct contact with and responsibility for resident students, as well as supervisory responsibility for para-professional staff in their residential buildings and complexes. They are significant influences for the education, leadership, and management in residence halls, whether in large systems or small, public or private. (p. 11) There is a strong need for well-qualified, educated, and trained entry-level live in professional staff in campus residence halls to support and achieve the institution's academic and educational goals during the first year when freshmen transition from high school to college (Belch, Wilson, \& Dunkel, 2009). 
Freshmen Transition. The resident director's role within the educational process of student learning is especially critical during the freshmen year. The college years can be among the most eventful ones of an individual's life. Today's first-year students arrive on campus with more problems than ever before (Archer \& Cooper, 1998). College life presents students with numerous opportunities for personal, social, intellectual, and professional development. However, these new opportunities are also coupled with challenges that undergraduates have to face. Chandler \& Gallegher (1996) noted that these challenges could be broken down into three basic categories: academic, social, and psychological.

Academic challenges. First and foremost, students must succeed academically. However, many first-year college students have a hard time understanding the academic demands. When entering first-year students describe their expectations for college-level work, most identify the fact that they will need to work twice as hard as they did in high school. When asked how to accomplish this, they simply state they will need to study twice as hard as they did in high school. Realistically, they probably need to study ten times more than they did in high school if they are to meet college-level expectations of devoting two or three hours of study time for every one hour time spent in class (Upcraft, Gardner, \& Barefoot, et. al. 2005). When students finally understand the amount of time necessary to study and be a successful student, it can be devastating. During the first year of college, many students experience stress and anxiety associated with academic performance and expectations (Jones \& Frydenberg, 1999).

It is important to identify students who are struggling academically early in the semester. "If students recognize when they are stressed and aware of the strategies they can employ to manage their stress and anxiety, their coping abilities can be enhanced and their repertoire of coping strategies expanded" (Frydenberg, 1997 in Jones \& Frydenberg 1999, p. 4). It is the 
responsibility of the resident director to identify these students as soon as possible and get them the support they need. Additionally, the resident director is proactive in providing academic support. They coordinate study sessions, provide programs that teach study skills, bring faculty into the hall to discuss academic expectations, and mentor students who are identified as being a high risk (i.e. high school GPA, ACT/SAT scores, etc).

Social challenges. College students are at a developmental stage in which establishing interpersonal relationships are particularly critical (Chickering, 1969). This can be difficult for students in the residence halls, who find themselves living in a diverse and multicultural environment. On-campus students' living communities are made-up of students who have different ethnicities, race, socioeconomic status, religious beliefs, and sexual preferences. Some college students have never had to share a bedroom with anyone else, let alone share a bedroom with someone of a different background. Baker and Siryk (1980) indicate that many students experience social alienation when they first attend a university and many decide not to return after their freshmen year. Students who perceive low levels of social involvement in their residence hall tend to be unhappy (Gerst \& Sweetwood, 1973). There is evidence that shows lack of a good social environment in residence halls is associated with students' feelings of alienation (Goebel, 1976). Negative social interactions lead to dissatisfaction with their living situation and contribute to poor emotional adjustment. However, positive roommate, suitemate, and floormate relationships contribute to a constructive social support system and reduce the feeling of alienation. It is the responsibility of the resident director to reduce these feelings of alienation by providing social programming to engage students. The resident director also trains and coaches the resident assistants on the proper mediation techniques to overcome roommate and other social conflicts, enhancing the students' social experience. 
Psychological challenges. When college students first arrive on campus, their psychosocial resources are in a state of flux, putting them at risk for encountering psychological disorders (Caplan \& Grunebaum, 1967). Many factors contribute to this state of flux including lack of social support, academic pressures, financial problems, and being away from home and for the first time. These issues can lead to feelings of alienation, loneliness, homesickness, and depression. College students experience these feelings at much higher levels than those of the same age who are not attending college (Sax et al., 2000). Institutions counseling services are generally able to provide short-term psychological assistances for these students. However, students are often reluctant to seek counseling. Counselors are frequently called upon to assist student affairs staff with behavioral issues that arise in the residence halls or development problems that the residence hall staff encounter while working with students (Upcraft, Garder, Barefoot, 2005, p. 432). It is not uncommon for a resident director to be one of the first professional persons responding to a suicide attempt or to witness a mental breakdown of a student. 


\section{Level of Preparation}

Rickgarn (1988), in the book Suicidal Encounters, wrote:

My experience in the area of suicide prevention, intervention, and postvention began with nine attempts and one completed suicide in 1 year when I was the director of a predominantly single-room, 650-person residence hall. As one incident followed another and some individuals engaged in repeated attempts, I began to seriously question my ability to work with suicidal persons and to provide leadership to the resident assistant staff, who were also deeply involved in these situations. (p.97)

Resident directors must be well prepared to assume the duties of their positions or the consequences can be extreme. The types of crisis situations that occur in the residence halls may cause a high degree of strain on resident directors and other residence life staff. As one crisis situations follows another, stress and exhaustion of the staff increases. Yet students' lives depend on the ability of the residence hall staff to respond immediately, with a clear and appropriate plan of action, when a crisis situation arises. A resident director must be appropriately trained and capable of handling the stress or a condition called "burnout" can occur. "Christine Maslach defined burnout as a sense of exhaustion, cynicism, and negative selfevaluation about the work experience" (Nelson, 2005 in Ellett, Belch, et. al, 2008, p. 7). When a resident director experiences job burnout, decision-making can become chaotic and unclear. This condition seriously hinders their ability to carry out their responsibilities. Housing administrators can address the problem of resident director job burnout by "recruiting and selecting staff who are better prepared to handle the unique demands of the housing and residence life operations" (Ellett, Belch, et. al., 2008, p.7). "The critical element necessary for ensuring the success of residential programs in the development of community, attaining the 
goals for student development and enhancing student learning is professional staff with sufficient credentials, training, and experience" (Stimpson, 1994; Winstson \& Anchors, 1993 in Belch \& Mueller, 2003, p. 29).

Recruiting highly qualified staff, providing extensive training, and creating an environment of professional support are key factors that help ensure that the resident director has the ability to succeed and excel in this unique work environment. "A shortage of well-educated and trained professional staff working with students in residence halls will have a significant impact on the development of the community, the student learning process and the personal development of students" (Belch \& Muller, 2003, p. 31).

Recruitment and hiring qualifications. Despite the realization by university administrators of the importance of the resident director position, recruiting and hiring resident directors has been identified as one of the major challenges confronting residence life programs (Bliming, 1993). Challenges with the recruitment of well-qualified, entry-level residence life staff were first identified in 1958 when Dr. Donald Kilbourn, the first Association of College and University Housing Officers - International (ACUHO-I) president, gave his inaugural speech to the ACUHO-I delegates. Many of these same challenges still exist today (Scheuermann \& Ellett, 2007). Scheuermann \& Ellett (2007) in the book A $3 D$ View of Recruitment and Retention of Entry-level Housing Staff, wrote:

The challenge of identifying and sustaining adequate pools of highly qualified, wellprepared, and committed staff members to work in entry-level positions at our institutions, whether public or private, large or small, remains a vexing challenge for housing and residential life professionals across the field. (p. 12) 
In another study, Belch and Mueller (2003) conducted a comprehensive survey of chief housing officers and graduates students regarding the declining number of resident directors. Their research reflected that "quality of life, remuneration, and lack of interest in the residence life profession were significant issues" (p. 29). These factors can be attributed to diverse job responsibilities, the twenty-four hour, on-call work requirement, the lack of privacy, and the need to be an ambassador for the university at all times, whether on or off the "artificial" clock.

"Young professionals today are not as willing or interested in taking live-in positions with long hours, lack of privacy and relatively low pay for a person with an advanced degree" (Kearney, 1993, in Winston et al., p. 288). Today, while most resident director positions are advertised as "master'ss preferred," they are ultimately filled by candidates with bachelor's degrees. Additionally, most institutions require residence hall or student development experience. Administrators must often choose between a master's-level candidate with little or no residence hall experience or a bachelor's degree candidate with the appropriate experience. This situation is typical in the field and illustrates the need to re-examine current approaches to recruitment (Scheuermann \& Ellett, 2007). Given that housing officers are sometimes forced to hire candidates who either lack the credentials or experiences required of the position, extensive training is required to ensure that the newly hired resident director is sufficiently prepared to succeed in their new role.

Before one can understand why these challenges still exist, it is important to understand the job responsibilities and the various requirements (such as skills, education, and experience) needed to be effective in student affairs mid-level management positions.

Job responsibilities. The specific job responsibilities for resident directors vary across the field. There should be common elements for resident directors who are full-time, live-in, entry- 
level student affairs professionals responsible for the oversight of a residential facility, including aspects of staff and student development. The resident director is one of the very few university professional staff members who work with students throughout the day, and the night. In addition to providing programming and support for students in their hall, they supervise resident assistants (RAs) and other para-professional or professional staff members. In some institutions, the resident director is also responsible for student conduct, and thus adjudicates disciplinary cases. The resident director teaches courses and counsels student organizations. They negotiate roommate issues, deal with homesick students, and calm down irate and/or intoxicated students. They serve as a role model for their staff and a mentor for the residence hall community.

For many students, the residence hall is the place where they experience their first anxieties of the college environment and the difficulties that are associated with adjusting to new and diverse people. First-year students in the residence hall also experience freedoms never before afforded to them. First-year students often struggle with balancing their freedom so that they can become independent, functioning adults. As these students test their autonomy, the residence hall staff members help assure that they are safe in doing so. The residence hall is a mini-society, comprised of a diverse population, therefore crises are inevitable. The residence hall staff members are unavoidably involved in the problems, personal dilemmas, aspirations, and hopes of the students with whom they live. They are almost always one of the first responders to any emergency situations that may arise in the hall including sexual assaults, suicide attempts, the passing of student or a student's family member or friend, and numerous other physical or psychological issues. In a time of crisis, the resident director becomes the main liaison to other departments such as emergency personnel, campus police, counselors, student conduct officers, and administration. 
Skills required. A proficient resident director must command a wide-range of skills and competencies that enable him or her to handle the most unusual situations. These situations are often difficult to outline in a procedural manual. Resident directors must be able to analyze these situations and respond immediately. They must be flexible, critical thinkers. In August 1990, Association of College and University Housing Officers - International (ACUHO-I) housing directors were asked to list the competencies necessary to be effective residence life professionals. "A list of fifty-five competencies was created, and ten competencies were determined to be the most important. One of the most important competencies was being able to work cooperatively with a wide range of individuals" (Kearney, 1993, in Winston et al., p. 289). Sermershiem \& Keim (2005) found that student affairs mid-level managers rated leadership and personnel management as the most important skills needed in their positions. This is also reflected in Kane's (1982) research where respondents ranked leadership and personnel skills as very important and Fey's (1991) research that rated "personnel management as the most important followed by leadership, communication, student contact, and professional development" (p. 45). Belch and Mueller (2003) noted that over the past thirty years, skills such as leadership, communication, and interpersonal relations continued to be essential for hall directors to be successful in their position. "Leadership is essential to the creative improvement of services and program for our increasingly diverse student populations" (Clement \& Rickard, 1992, p.3).

Educational requirements. In November 2004, the Association of College and University Housing Officers - International (ACUHO-I) surveyed its Chief Housing Officer (CHO) members on issues surrounding the recruitment and retention of entry-level staff. When asked to list the educational credentials they required for hiring entry-level staff, a majority of 
the CHOs who responded to the survey "required their entry-level staff to hold either a master's $(31.2 \%)$ or a bachelor's $(57.6 \%)$. None required an earned doctorate or enrollment in a doctoral program; however, $6.2 \%$ expected their bachelor's-level new staff to be enrolled in a master's program" (St. Onge, Ellett, \& Nestor, 2008, p. 15-16). While this study was conducted in 2004, a review of vacant positions posted on HigherEd Jobs.com (2010) revealed that these same educational requirements exist today. Most colleges and university require their live-in resident director candidates to have a minimum of a bachelor's degree. Institutions who hire candidates with a bachelor's degree require a combination of the bachelor's degree along with extensive experience within the student affairs field; extensive experience being defined as more than three years. However, most housing and residence life departments prefer their resident director candidates to have a master's degree in a related field (i.e. higher education, administration, counseling, social work, or student personnel). Of course, there are variations to these requirements. For example, a positions posted for resident coordinator at Trinity Washington University in Washington, DC states the "successful candidates may be graduate students or new professionals with previous student leadership/undergraduate residence life experience" (HigherEd Jobs.com, 2010). The position at Trinity is a live-in position but, according to the advertisement, is part-time instead of full-time. On the other hand, some institutions, such as Virginia Tech and Drexel University, require a master's degree (HigherEdJobs.com, 2010) in addition to the appropriate experience.

Experience required. According to website searches conducted on resident director and area advisor positions listed on HigherEdJobs.com (2010), the experience required to be eligible for the resident director position is listed as a minimum of 1-2 years experience working with students in a residential setting. This experience typically reflects the candidate's ability to 
conduct educational programming, coordinate workshops, develop communications and promotional literature, recruit for programs, work with students from diverse student population, and respond appropriately to crisis situations. Many entry-level housing and residential life staff members gain this experience as a Resident Assistant or Resident Advisor (RA). Since many resident directors gain their first exposure to residence life and housing through the RA position, and RAs comprise a large portion of the resident director candidacy pool, it is beneficial for purposes of this research to understand the job responsibilities of the RA position (Scheuermann \& Ellett, 2007).

An RA is a "paraprofessional" staff member, generally of sophomore status or above, who lives in the residence halls. Paraprofessional staff is defined as "student staff who are selected, trained and supervised to assist in peers' personal and academic development while attending to environmental aspects of the living area" (Winston \& Fitch, 1993 in Benjamin, 2007, p. 31). "The (RA) serves a crucial role in establishing, facilitating, cultivating, and maintaining an environment for personal and community development for their residents" (Gentry, Harris \& Nowicki, 2007, p. 61). Because RAs have recently experienced the freshmen transitional period and are close in age to the freshmen students, they serve as a critical element in the residence hall staffing organization. The RA is the first contact a student has when there is an issue that needs to be addressed. They are often perceived as a mentor and role model for the students. Like the resident director, the RA has multiple roles and responsibilities. Similar to the resident director position, there is a high level of stress associated with these multiple roles and responsibilities (Deluga \& Winters, 1990). Miller and Coyne (1980) found that paraprofessional staff, such as RAs, reported significantly more personal problems than students in general. 
The RA position is not just a job; it is a lifestyle. After serving in this role for several years, many RAs are ready to graduate and move on to another line of work outside of the residence halls. At the conclusion of the 2002 National Association of College and University Residence Halls (NACURH) residential student leader conference, students were surveyed about the field of housing and student life. "Surprisingly, $64 \%$ of the students stated that they planned on entering student affairs as a profession, but the vast majority thought they would look into fields other than housing and residence life" (Scheuermann \& Ellet, 2007, p. 13). Given that: (1) the resident director position requires residence hall experience, (2) this experience is usually gained through the RA position, (3) there is a high level of stress and problems associated with the RA position, and (4) RAs tend to pursue other positions outside of housing and residence life, it is understandable why a small portion of the RAs enter the resident director candidacy pool, making recruitment of the resident director positions especially challenging.

Resident director training. There are few departments within higher education that require staff to train every year, regardless of years of service. The Department of Residence Life is unique in this aspect. Most institutions require their resident directors to complete training during the summer, prior to the residence halls opening in the fall. This training is usually focused on enhancing the resident director's knowledge, skills, and abilities beyond those gained as a resident assistant. While training for new resident directors is an on-going process, the summer training is more intensive and often mandatory for newly hired resident directors as well as experienced resident directors. The summer training provides chief housing officers with the ability to address new policies and procedures and reiterate other processes with the entire staff. 
Canon (1980) noted that training is needed for professionals working within the field of student affairs for three common purposes: the remediation and rehabilitation of marginally trained or skilled professionals, the enhancement of accountability to the institution for what one does as a professional, and the exercise of professional responsibility in the form of ensuring one's own professional growth. Although the length of summer training and the topics covered varies between institutions, common elements can usually be found. According to Reslife.Net (2010) resident director training should provide staff members with a better understanding of the following areas: (1) staff team development, (2) judicial administration, (3) supervision of residence hall programming, (4) hall government advisement, and (5) creating balance between one's personal and professional life.

\section{Retention and Organizational Culture}

Retention of entry-level student affairs professionals is "essential to the health of student affairs as a profession" (Davis, Barham \& Winston, 2006, p. 64). Chief housing officers have acknowledged a concern with the ability to recruit and retain highly qualified professional staff members interested in entry-level, live-in positions (Belch \& Mueller, 2003). Concerns about effectively recruiting and retaining young professional student affairs staff, including residential life staff, are not new (ACPA \& NASPA, 1988). Jones (2002) noted that "within student affairs, professional staff appear to be handicapped when it comes to retaining recruits" (p.8).

Estimates of attrition rates of new professionals in the student affairs field vary. A study of chief housing officers conducted by St. Onge, Ellett \& Nestor (2008) found that a majority of entry-level staff members remained in their positions "an average of 2-3 years (44.5\%) or 3-4 years $(26.7 \%)$. In fact, few staff stayed less than two years, with the smallest percentage being for entry-level staff being retained for less than 1 year (1.7\%)" (p. 16). "Considering the 
investment made in recruiting and training entry-level staff, minimizing attrition while simultaneously increasing effectiveness is beneficial to both staff members and the department in which they work." (Collins \& Hurt, 2006, p. 14). Therefore, it is important to determine what factors may help increase the retention rate of entry-level professional staff members.

St. Ogne, Ellett, and Nestor (2008) conducted a study of chief housing officers (CHOs) to review such factors. Their study showed that the $\mathrm{CHOs}$ felt that the following factors were crucial for improving the retention rate of entry-level student affairs positions: opportunities for professional development, appropriate supervision and mentor support, rewards such as better salaries and benefits, and the opportunity for advancement. St. Ogne, Ellet, \& Nestor (2008), in the book Modifying RA Training in Support of a Custom Programming Model, wrote:

Although salary and benefits are important, housing professionals should not underestimate the importance of availability of professional development opportunities, job duties, and supervision/support as key factors that candidates and staff consider when making decisions. These non-tangible aspects of the entry-level position may be key considerations for decisions made by potential and current staff to take a new position or remain in their current position. (p. 21)

The support provided by administration influences the overall culture of the organization, which determines the level to which these factors exist. "Perceived job satisfaction is pivotal to the recruitment, productivity, commitment, and success of entry-level live-in professional staff and a strong and healthy culture can promote it" (Belch, Wilson, \& Dunkel, 2009, p. 178).

Professional development. Schrieber, Dunkel, and Jahr (1994) defined professional development as "involvement in activities that are intended to enhance professional effectiveness, and are chosen as a result of decision-making process based on assessment of 
skills and designed goals while targeting skill development" (p. 26). Continuing professional development is a foundation of the student affairs field. According to the National Association of Student Personnel Administrators (NASPA) Standards of Professional Practice, specifically the $17^{\text {th }}$ standard under Professional Development:

Members have an obligation to continue personal professional growth and to contribute to the development of the profession by enhancing personal knowledge and skills, sharing ideas and information, improving professional practices, conducting and reporting research, and participating in association activities. Members promote and facilitate the professional growth of staff and they emphasize ethical standards in professional preparation and development programs. (NASPA, 2010)

Sermerseheim and Keim (2005) found that the most preferred professional development activities for mid-level managers are attending national, regional, or state professional association conferences, discussions with colleagues, and professional association workshops (p.46). These findings parallel similar findings of Fey (1991), Lemoine (1985), and Miller (1975). Barr and Desler (2000) stated that at the very least, professionals should read current literature and attend conferences when possible. Discussions with colleagues, attending workshops, and keeping up with current literature are relatively inexpensive types of professional development. However conferences, especially national conferences, are normally costly and budgetary constraints often limit this type of professional development. Additionally, it is difficult for residence hall staff members, who work long hours and are often pursuing an advanced degree, to find time to read professional literature. If funding permits, housing officers often send resident directors to conferences as an incentive because it provides a professional 
development opportunity as well as the much needed break from the day-to-day operations of the residence hall.

Mentors. "The importance of cultivating relationships with newcomers to the organization, at both the recruitment and socialization phases is embedded in the ideals of ownership and involvement, and is essential to communicating organizational culture and values" (Kuh et. al., 2005, in Belch, Wilson, \& Dugel, 2009, p. 177). The culture of an organization influences the employee's attitude regarding commitment, motivation, morale, performance, and job satisfaction (Harris \& Mossholder, 1996; Schein, 1999).

Young professionals often view their senior staff members as mentors. Young professionals can reap substantial benefits from mentor relationships. Mentors serve as a role model for their protégé by demonstrating highly skilled levels of performance that is worthy of imitation. "Further, role models furnish the new professional with career advancement patterns and histories of professional achievement. Role models, then, can illustrate how professional behaves as well as what a professional does" (Schmidt \& Wolfe, 2009, p. 372).

Rewards and benefits. Another factor that affects the recruitment and retention of resident directors are the rewards and benefits associated with the position. There are two types of rewards that motivate people: intrinsic and extrinsic. Extrinsic rewards are those that are external to the job and are provided by the employer. For the common employee, extrinsic benefits may include salary, health plan, retirement, promotions, raises, and domestic partner benefits. Because resident directors are live-in positions, they have additional, unique extrinsic rewards to consider. These include meal plan options, living arrangements, live-in partner benefits, and the ability to have pets. In addition, they may receive funding to attend and/or participate in national and regional conferences as well as receive funding to attend workshops 
held at other colleges or universities. Housing officers need to keep abreast of what other institutions offer in these areas so that they can offer competitive employment packages. "The recent growth of the Internet as a source for information on aspects of campus data allows candidates and employers to compare and contrast institutional benefits for professional and graduate-level positions" (Scheuermann \& Ellett, 2007, p.13).

Intrinsic rewards are the types of benefits that are internal to the individuals and are gained from performing the job itself. These rewards derive from the personal satisfaction of accomplishing something worthwhile, assuming personal responsibility for duties, overcoming challenges that are presented, or having purpose and autonomy. These rewards can also be associated with receiving positive or meaningful feedback from a supervisor. "While (extrinsic) rewards and important (Anderson et al, 2000; Solmon \& Tierney, 1977), intrinsic rewards are more highly valued among student affairs professional. Engaging in meaningful work, operating autonomously, and influencing major decisions are all intrinsic in nature and are all more highly valued by student affairs professionals" (Hirt, Amelink, \& Schneiter in Collins \& Hirt, 2006, p. $6)$.

\section{Summary of Literature Review}

There is considerable research to show that the resident director position is a necessary and crucial student affairs staff position responsible for the academic and personal success of students who reside in the residence halls. In order for a resident director to be successful in their position, he or she must be appropriately prepared to handle the unique responsibilities associated with working in the residence life field. It takes an extremely dedicated person to work within this demanding field. Young professionals today are often unwilling to commit to the type of lifestyle that resident directors must endure. Research shows that housing officers 
find it difficult to recruit and retain resident directors. Challenges associated with the recruitment and retention of highly qualified, entry-level housing and residence life staff members can be dated back over 50 years. Many of these same challenges, associated with a high burnout rate with the profession, still exist today (Scheuermann \& Ellet, 2007). In order for higher education administrators to overcome these challenges, it is important to understand more about the resident director position, residence hall life in general, and the challenges associated with working in the residence life field.

\section{Key Terms and Concepts}

For the purposes of this research, the following definitions will be utilized:

ACUHO-I: " ACUHO-I is the Association of College and University Housing Officers -

International. ACUHO-I members believe in developing exceptional residential experiences at colleges, universities, and other post-secondary institutions around the world. ACUHO-I achieves its vision by providing innovative, value-driven programs, services, research, and development as well as networking opportunities that help support and evolve the collegiate housing industry. ACUHO-I members include thousands of housing professionals from more than 900 colleges and universities in 22 different countries, who serve approximately 1.8 million students worldwide. Membership also includes more than 200 corporate members" (ACUHO-I, 2010).

Benefits: Benefits and rewards are the advantage, privilege, right, or financial incentives (such as salary, retirement, medical, leave, etc) provided to an employee. There are two types of rewards: intrinsic or extrinsic. Extrinsic rewards are those that are external to the job and are provided by the employer. Intrinsic rewards are the types of rewards that are internal to the 
person are gained from performing the job itself. (Hirt, Schneiter, \& Amerlink in Collins \& Hirt, 2006).

Burnout: "Christine Maslach defined burnout as a sense of exhaustion, cynicism, and negative self-evaluation about the work experience" (Nelson, 2005 in Ellett, Belch, et. al, 2008, p. 7). Incentives: Rewards offered (such as benefits, professional development, salary) for encouraging candidates to apply for a position or to keep current employees from leaving a position.

Mentor: Mentors are role models for their protégé by demonstrating highly skilled levels of performance that is worthy of imitation. "Further, role models furnish the new professional with career advancement patterns and histories of professional achievement. Role models, then, can illustrate how professional behaves as well as what a professional does" (Schmidt \& Wolfe, 2009, p. 372).

Organizational Culture: "Organizational culture is a shared system of beliefs, values, and assumptions among an organization's inhabitants (Denison, 1996, Kuh \& Whitt, 1988; Schein, 2004 in Belch, Wilson, \& Dunkel, 2009). Organizational members share a common understanding that unities them; helps them to understand how they fit in; and learn what is valued, appropriate, and inappropriate (Allen \& Cherrey, 2000; Schein, 1992; Sims, 1994 in Belch, Wilson, \& Dunkel, 2009). In essence, culture guides the activities of an organization" (Sims, 1994 in Belch, Wilson, \& Dunkel, 2009).

Paraprofessional Staff: Paraprofessional staff is defined as "student staff who are selected, trained and supervised to assist in peers' personal and academic development while attending to environmental aspects of the living area" (Winston \& Fitch, 1993 in Benjamin, 2007, p. 31). 
Professional Development: "Involvement in activities that are intended to enhance professional effectiveness, and are chosen as a result of decision-making process based on assessment of skills and designed goals while targeting skill development” (p. 26).

Qualifications (Employment): Employee qualifications are the level of professional experience and/or educational requirements needed for an employee to perform a specific job. Minimum qualifications are generally set by the employer, usually designated by professional standards. Recruitment (Employment): Employee recruitment is the act of a seeking and attracting the best qualified workers to fill vacancies. Appropriately advertising and showcasing an organization's benefits are important components of the recruitment process. Effective recruitment is important so that organizations can maintain high organizational performance and minimize labor turnover.

Residence Life: Residence life is the terminology used to describe the comprehensive program that surrounds the experience of living in a residence hall at a college or university. The Residence Life department oversees a structured housing program that plans events, enforces specific expectations for behavior, and manages residence life staff members who carry out these responsibilities.

Resident Assistant or Resident Advisor (RA): A resident assistant, also known as a resident advisor (RA), is a trained, paraprofessional, upper-class student-staff member who lives in the residence halls. An RA has many roles and responsibilities. Mostly the RAs serve as a peer mentor to students because they have a wealth of knowledge about campus resources available to students. They also must enforce residence hall policies so that the residence hall environment is conducive to academic success. 
Resident Director: A live-in, entry-level student affairs professional staff member responsible for the oversight of a university or college residential facility, including aspects of staff and student development. Also known as Residence Hall Coordinator, Residence Hall Director or Community Coordinator.

Residence Life Administrator: A student affairs professional staff member who works in the field of Residence Life or Housing. The Residence Life Administrator will have either direct or indirect supervision of the Resident Directors. Common titles include Area Coordinator, Area Advisor, Assistant Director, Associate Director, or Director.

Retention (Employment): Employee retention is the act of keeping a person secured in their position. Effective employee retention is a systematic effort by employers to create and foster an environment that encourages current employees to remain employed by having policies and practices in place that address their diverse needs. (Workforce Planning for Wisconsin State Government, 2005).

Training: Formal and informal activity aimed at imparting information and/or instructions to improve the staffs' level of performance and to help him or her attain a required level of knowledge or skill. Portions of resident director training is often required prior to assuming full responsibility of duties while other portions can only be gained through on-the-job experience. 


\section{Chapter Three}

\section{Methodology}

Higher education institutions rely on resident directors to ensure the safety of residence hall students, and to preserve an environment that is conducive to academic excellence. The unique responsibilities and working environment of the resident director position rank this job as one of the most important and challenging on campus. Residence life "administrators are legitimately concerned about the perceptions of work life held by their staff members. Positive perceptions among staff affect their morale (Johnsrund \& Rosser, 1999), their intent to leave their positions (Johnsrud, Heck, \& Rosser, 2000), and their productivity (Anderson, GuidoDibrito, \& Morrell, 2000)" (Collins \& Hurt, 2006, p. 14). The Introduction and Literature Review of this dissertation research provided an in-depth look at the problems administrators face with the recruitment and retention of resident directors. In Chapter Three, the researcher will further analyze these challenges by evaluating specific factors at 18 institutions within the United States. These factors include a review of these institutions':

1. Resident Directors' Level of Preparation

a. Recruitment and Hiring Qualifications

i. Skills Required

ii. Educational Requirements

iii. Experience Required

b. Training

2. Retention affected by Organizational Culture 


\section{a. Professional Development}

\section{b. Mentoring}

\section{c. Rewards and Benefits}

It is intended that this research will serve as a blueprint of best practices so that residence life administrators can enhance recruitment efforts on their campuses and increase the retention rate of resident directors on their staff. This chapter will provide a rationale for the methodology utilized for this study. It also contains information on the research design, site selection and profile, sampling procedure, data collection, survey instruments, method of data analysis, limitations of the study, and background of the researcher.

\section{Research Design}

Through the literature review, the researcher discussed the issues that exist in the ability of residence life administrators to recruit and retain highly qualified resident directors. The researcher believes that there are certain factors that will aid administrators in forming best practices for the recruitment and retention of resident directors. In order to collect data to better understand these factors, the quantitative framework approach will be utilized for this research design. "A quantitative approach is one in which the investigator primarily uses postpositivist claims for developing knowledge, employs strategies of inquiry such as experiments and surveys, and collects data on predetermined instruments that yield statistical data" (Creswell, 2003, p. 18).

The researcher developed two separate survey instruments (see Appendices A and B) containing questions that addressed information about recruitment and retention practices at 18 institutions within the United States. Eleven of these institutions were identified by an 
Association of College \& University Housing Officers - International (ACUHO-I)

Commissioned Research Program (Ellett, et. al., 2008) as having best practices in the recruitment and/or retention of resident directors and seven were selected from West Virginia University's (WVU) Higher Education Policy Commission (HEPC) peer institutions. While there are twenty WVU HEPC peer institutions, there is an overlap of three institutions appearing on both lists. Seven HEPC institutions were utilized to make the number of participants of ACUHO-I best practice institutions and WVU HEPC institutions as equivalent as possible. The surveys were administered to resident directors and residence life administrators at the designated institutions utilizing the on-line survey tool SurveyMonkey ${ }^{\mathrm{TM}}$. An on-line survey tool was preferred because of the convenience and the cost benefits.

\section{Site Selection and Institutional Profile}

The researcher intends to utilize the findings of this research to determine best practices for the recruitment and retention of resident directors, so that these practices can be implemented at large public institutions, as well as small private institutions. The researcher also intends to utilize the finding to implement best practices at West Virginia University. Therefore the researcher surveyed resident directors and residence life administrators at 11 institutions identified as having best practices in the recruitment and/or retention of resident directors by an Association of College \& University Housing Officer s- International (ACUHO-I)

Commissioned Research Program (Ellett, et. al., 2008) and seven institutions selected from West Virginia University's (WVU) Higher Education Policy Commission (HEPC) peer institutions (HEPC Peers, 2011).

ACUHO-I best practice institutions included: Alfred University, East Carolina University, Kansas State University, Seton Hall, University of Wisconsin-Oshkosh, Emerson 
College, University of Georgia, Western Illinois, Ball State University, University of Florida, and University of Maryland College Park. The ACUHO-I best practice institutions included three private and eight public universities. The population of these institutions ranged from 2,319 to 50,691 (see Table 1). With the exception of East Carolina University, the institutions are classified by the Carnegie Foundation as "primarily residential or highly residential" institutions (Carnegie Foundation, 2011).

Table 1

Institutional Profile of ACUHO-I Best Practice Institutions

\begin{tabular}{|c|c|c|c|}
\hline Institution & Student Population & Type & Carnegie Classification \\
\hline Alfred University & 2,319 & Private & $\begin{array}{c}\text { Master's Colleges and Universities } \\
\text { (larger programs) }\end{array}$ \\
\hline Emerson College & 4,556 & Private & $\begin{array}{c}\text { Master's Colleges and Universities } \\
\text { (larger programs) }\end{array}$ \\
\hline $\begin{array}{c}\text { University of } \\
\text { Wisconsin-Oshkosh }\end{array}$ & 13,192 & Public & $\begin{array}{c}\text { Master's Colleges and Universities } \\
\text { (larger programs) }\end{array}$ \\
\hline $\begin{array}{l}\text { Western Illinois } \\
\text { University }\end{array}$ & 12,679 & Public & $\begin{array}{c}\text { Master's Colleges and Universities } \\
\text { (larger programs) }\end{array}$ \\
\hline $\begin{array}{c}\text { East Carolina } \\
\text { University }\end{array}$ & 27,654 & Public & Doctoral/Research Universities \\
\hline Seton Hall & 9,616 & Private & Doctoral/Research Universities \\
\hline $\begin{array}{c}\text { Kansas State } \\
\text { University }\end{array}$ & 23,581 & Public & $\begin{array}{l}\text { Research Universities } \\
\text { (high research activity) }\end{array}$ \\
\hline Ball State University & 21,401 & Public & $\begin{array}{l}\text { Research Universities } \\
\text { (high research activity) }\end{array}$ \\
\hline \begin{tabular}{|c|} 
University of \\
Maryland-College Park
\end{tabular} & 37,195 & Public & $\begin{array}{c}\text { Research Universities } \\
\text { (very high research activity) }\end{array}$ \\
\hline University of Georgia & 34,885 & Public & $\begin{array}{c}\text { Research Universities } \\
\text { (very high research activity) }\end{array}$ \\
\hline University of Florida & 50,691 & Public & $\begin{array}{c}\text { Research Universities } \\
\text { (very high research activity) }\end{array}$ \\
\hline
\end{tabular}

Source: Carnegie Foundation, 2011

WVU's HEPC peer institutions included North Carolina State University-Raleigh, SUNY at Buffalo, Texas A\&M, University of Connecticut, University of Florida, University of Georgia, 
University of Hawaii at Manoa, University of Iowa, University of Kentucky, University of Louisville, University of Maryland-College Park, University of Massachusetts-Amherst, University of Missouri-Columbia, University of Nevada-Reno, University of New Mexico-Main Campus, University of Tennessee, University of Utah, University of Vermont, Virginia Commonwealth University and Virginia Tech. WVU's peer institutions included twenty public universities. The student population of these institutions ranged from 11,714 to 50,691 . With the exceptions of Texas A\&M, University of Hawaii, University of Louisville, University of Nevada, University of New Mexico, and Virginia Commonwealth University, the institutions were classified by the Carnegie Foundation as "primarily residential or highly residential" institutions (Carnegie Foundation, 2011).

There were three institutions known as ACUHO-I best practice institutions that were also WVU HEPC peer institutions. These institutions were: University of Florida, University of Georgia, and University of Maryland-College Park. For purposes of the data analysis, they were included as ACUHO-I best practice institutions, not WVU HEPC peer institutions. So that the number of participants for ACUHO-I best practice institutions was similar to the number of participants for WVU HEPC peer institutions, seven WVU HEPC peer institutions were selected. Table 2 reflects the institutional profile of those selected as WVU HEPC peer institutions.

Table 2

Institutional Profile of Selected WVU's HEPC Peer Institutions

\begin{tabular}{|c|c|c|c|}
\hline Institution & Student Population & Type & Carnegie Classification \\
\hline $\begin{array}{c}\text { North Carolina State } \\
\text { University -Raleigh }\end{array}$ & 33,819 & Public & $\begin{array}{c}\text { Research University } \\
\text { (very high research) }\end{array}$ \\
\hline $\begin{array}{c}\text { University of } \\
\text { Connecticut }\end{array}$ & 25,029 & Public & $\begin{array}{c}\text { Research Universities } \\
\text { (very high research activity) }\end{array}$ \\
\hline University of Iowa & 28,987 & Public & $\begin{array}{c}\text { Research Universities } \\
\text { (very high research activity) }\end{array}$ \\
\hline
\end{tabular}

(continued) 


\begin{tabular}{|c|c|c|c|}
\hline Institution & Student Population & Type & Carnegie Classification \\
\hline $\begin{array}{c}\text { University of Kentucky } \\
\begin{array}{c}\text { University of } \\
\text { Amhachusetts - }\end{array}\end{array}$ & 26,295 & Public & $\begin{array}{c}\text { Research Universities } \\
\text { (very high research activity) }\end{array}$ \\
\hline $\begin{array}{c}\text { University of Missouri- } \\
\text { Columbia }\end{array}$ & 31,237 & Public & $\begin{array}{c}\text { Research Universities } \\
\text { (very high research activity) }\end{array}$ \\
\hline Virginia Tech & 30,870 & Public & $\begin{array}{c}\text { Research Universities } \\
\text { (high research activity) }\end{array}$ \\
(very high research activity)
\end{tabular}

Source: Carnegie Foundation, 2011

\section{Sampling Procedure}

The participants in this research were resident directors and residence life administrators at the designated institutions. The researcher obtained the email addresses of all resident directors and residence life administrators on staff through the use of the institution's housing and residence life websites and staff directories. Once the names and email addresses of the residence life staff were obtained, a letter of invitation (Appendix D) and the appropriate SurveyMonkey ${ }^{\mathrm{TM}}$ survey link (Appendix A or B) were sent to all of the residence life staff members via email. Participants were notified that participation in the study was voluntary and individual responses would remain confidential. A response rate of $25-30 \%$ was desired. An overall response rate of $40.8 \%$ was achieved.

\section{Pilot Study}

After receiving approval from the West Virginia University (WVU) Institutional Review Board (IRB) for the protection of human subjects, a pilot study was conducted at West Virginia University. For the pilot study, the researcher asked twelve resident directors and three residence life administrators to complete the questionnaires. The questionnaires were solicited to the participants via email notification that directed participants to the appropriate SurveyMonkey ${ }^{\mathrm{TM}}$ 
survey link. Pilot subject participants were provided an adapted version of the participation invitation letter (Appendix C). At the time the pilot surveys were solicited, the pilot subjects were asked to critique the survey instruments to assure clarity. Immediately following the submission of the pilot email invitations, pilot participants were asked the following open-ended questions:

1. Approximately how long did it take for you to complete the questionnaire?

2. Do you believe the questionnaire's length was appropriate? If not, why?

3. Did you have any difficulties entering and completing the questionnaire? Please explain.

4. Do you have recommendations on how to make the questionnaire easier to complete? Please explain.

5. Were the questions clear and easy to understand? If not, what questions need to be modified?

6. Do you have recommendations on how to improve the questions? If so, which questions need improvement?

7. If a random drawing were held for a prize for participants who complete the questionnaire, what prize would you recommend within the price range of $\$ 25$ ?

8. Are there any other questions that you feel should be included in the survey that would help the researcher understand more about the recruitment and retention of resident directors?

9. Is there any other information you can provide to the researcher that will aid future participants in completing the survey

The researcher reviewed the information collected from the pilot study and determined the needed modifications for the final survey instruments. The participants were mostly satisfied 
with the survey and offered very minor suggestions that helped clarify some of the survey questions. The participants felt overall that the survey questions were easy to understand, that the survey instrument was easy to utilize and the survey length was not too long.

\section{Data Collection and Survey Instruments}

Once the suggested revisions were made, the researcher sent out letters of invitations via email (Appendix D) and the appropriate SurveyMonkey ${ }^{\mathrm{TM}}$ survey link (Appendix A or B) to the designated participants via email. The participants were given ten days to respond. If the participants did not respond within ten to fourteen days, an email reminder was sent through SurveyMonkey ${ }^{\mathrm{TM}}$.

The survey instruments were created by the researcher (Appendices A and B) and consisted of three main sections. The first section focused on demographic and participant information. The demographic questions provided self-reported information about the participants such as gender, age, ethnic affiliation, title, number of years in their position, profile of students living in the residence hall, resident director job responsibilities, and number of resident assistants supervised.

The second section of the questionnaire asked the participants questions that assessed the resident directors' level of preparation. The first portion of the section focused on resident director qualifications (i.e. skills, education, and experience) and recruitment methods. The second portion of the section focused on the training provided once resident directors were hired (Appendix A, Questions 12-42, Appendix B, Questions 11-37). These questions were designed based on information contained in the literature review. The researcher sought to identify the skills, education, experience, and training that resident directors needed to excel in their 
residence life environment. The researcher was also interested in determining how to effectively recruit highly qualified resident directors.

The third section of the questionnaires asked the participants questions relative to the retention of resident directors. These questions were designed based on information contained in the literature review. This section was divided into three subsections focusing on the institutions' organizational culture in areas of professional development, mentors, rewards and benefits (Appendix A, Questions 43-66, Appendix B, Questions 38-57). The researcher was seeking ways to identify what type of support institutions need to provide in order to retain high quality resident directors.

\section{Methods of Data Analysis}

Descriptive statistics were utilized to analyze the demographic and participant information data collected from the questionnaires. The responses from the demographic sections of the questionnaires were recorded, coded and percentages reported.

Demographic and participant information was collected for the following categories on both questionnaires with the exception of Question 4, which only applied to resident directors:

1. Gender

2. Age

3. Ethnic Affiliation

4. Live-in Spouse or Partner Arrangements (only on Resident Directors survey)

5. Title

6. Years as Resident Director or Residence Life Administrator

7. Years as a Resident Director or Residence Life Administrator at their Current Institution 
8. Academic Class Rank of the Residence Hall Population

9. Gender Profile of the Residence Hall Population

10. Job Responsibilities of the Resident Director

11. Number of Resident Assistants Supervised

Research Question 1: How well prepared are resident directors to assume their demanding leadership role?

Descriptive statistics were used to describe questionnaire items that addressed the first research question. Percentages were calculated for the two research questions that asked respondents to answer (a) how well prepared the resident director were when they first assumed their responsibilities, and (b) how well prepared they were to handle their responsibilities at the time of the survey. These questions were assessed through the use of a 5 Point Likert Scale (5=Very Well Prepared, 4=Well Prepared, 3=Adequately Prepared, 2=Poorly Prepared, 1=Very Poorly Prepared). The level of preparation when first hired was compared with the current level of preparation. Additionally, responses from the Resident Director Survey (Appendix A) and Residence Life Administrator Survey (Appendix B) were compared to determine if any variances existed between the two groups. Research Questions 1.(a). and 1.(b). helped determine the qualifications and training needed to prepare resident directors for their position.

Research Question 1.(a).: What qualifications (skills, education, and experience) do institutions require for resident directors?

To assist the researcher in understanding more about best practices associated with qualifications and recruitment, descriptive statistics were used to describe the questionnaire items that addressed this research question. Percentages were calculated and reported for the following areas: 
Skills: Respondents were asked to assess how important nine skills were in preparing a resident director to assume their duties. Responses were coded using the following Likert Scale levels (5=Very Important, 4=Somewhat Important, 3=Neutral, 2=Somewhat Unimportant, 1=Unimportant). The nine skills included: Interpersonal, Leadership, Personnel Management, Communication, Time Management, Mentoring, Problem Solving, Conflict Resolution, and Computer.

Education: Respondents were asked to rank the level of education (Some Undergraduate Work, Bachelors, Some Graduate Work, Masters, Doctorate) the resident directors (a) had when they were first hired and (b) currently had. To assist the researcher in understanding more about best practices associated with the level of education resident directors needed to be prepared, additional questions were asked about the resident directors' continuing education.

Experience: Respondents were asked about their years of experience ( $\geq 5$ years, 4 years, 3 years, 2 years, $\leq 1$ year) as (a) resident director, (b) resident assistant, and (c) as any other student affairs position.

Additionally, responses from the Resident Director Survey (Appendix A) and Residence Life Administrator Survey (Appendix B) were compared to determine if any variances existed between the two groups.

Research Question 1.(b).: What types of training are resident directors provided?

Descriptive statistics were used to describe questionnaire items that addressed this research question. Percentages were calculated and reported. The first section assessed when the resident director assumed their official duties prior to the academic semester (60 days prior, 30 days prior, 15 days prior, $<15$ days prior, after the academic year began). The second section addressed how long training lasted ( $>$ one week, one week, 3-6 days, 1-2 days, $<1$ day). The 
third section assessed how often training occurred (annually, semi-annually, quarterly, monthly, weekly). To assist the researcher in understanding more about best practices associated with the resident directors' training, additional questions were asked about the type of training offered. Responses from the Resident Director Survey (Appendix A) and Residence Life Administrator Survey (Appendix B) were compared to determine if any variances existed between the two groups.

Research Question 2: How likely are resident directors to be retained based on the institution's organizational culture?

Descriptive statistics were used to describe questionnaire items that addressed the second research question. Percentages were calculated for two research questions that asked respondents to answer how likely a resident director was (a) to continue as a resident director at their current institution next year and (b) how likely they were to continue as a resident director at another institution. These questions were assessed through the use of a 5 Point Likert Scale (5=Highly Likely, 4=Somewhat Likely, 3=Neutral, 2=Somewhat Unlikely, 1=Highly Unlikely). Descriptive statistics were used to describe the resident directors' plans to continue at their current institution ( $\geq 5$ years, 4 years, 3 years, 2 years, $\leq 1$ year). Research questions 2.(a)., 2.(b)., and 2.(c). helped determine how the organizational culture contributed to the retention of the resident director. Responses from the Resident Director Survey (Appendix A) and Residence Life Administrator Survey (Appendix B) were compared to determine if any variances existed between the two groups.

Research Question 2.(a).:What type of professional development opportunities exist?

To assist the researcher in understanding more about best practices associated with professional development, descriptive statistics were used and percentages calculated. 
Respondents were asked to assess institutional support of professional development through several questionnaire items.

\section{Research Question 2.(b).:What type of mentoring occurs?}

To assist the researcher in understanding more about best practices associated with mentors, descriptive statistics were used and percentages calculated. Respondents were asked about their institutions' use of professional mentors through several questionnaire items.

Research Question 2.(c).: What types of rewards and benefits are offered?

To assist the researcher in understanding more about best practices associated with rewards and benefits, descriptive statistics were used and percentages calculated. Respondents were asked about the likelihood to accept and/or stay in their position based upon certain rewards and benefits. Respondents were asked whether (a) institutions offered certain rewards and benefits (Yes or No) and (b) how important those reward and benefits were to the resident director (5=Very Important, 4=Somewhat Important, 3=Neutral, 2=Somewhat Unimportant, $1=$ Unimportant $)$.

Research Question 3: How do ACUHO-I best practice institutions compare to WVU's HEPC peer institutions?

To assist the researcher in determining if there is a difference in resident directors' recruitment and retention practices at WVU's HEPC peer institutions with those at ACUHO-I best practice institutions, the researcher compared results collected for Research Questions 1 and 2 from ACUHO-I best practice institutions with the results of those collected at WVU's HEPC peer institution.

The study's research questions are shown in Table 3 (Survey A: Resident Directors) and Table 4 (Survey B: Residence Life Administrators) with the corresponding survey questions. 
Additionally, the survey questionnaires are coded in Appendices A and B for committee review, but will not be coded in the actual survey administered to the residence life staff.

Table 3

Resident Directors Surveys-Research Questions \& Corresponding Survey Questions

\begin{tabular}{|l|c|}
\hline \multicolumn{1}{|c|}{ Research Question } & Corresponding Survey Questions \\
\hline 1. How well prepared are resident directors to assume & $12-13$ \\
their demanding leadership role? & $14-15$ (skills) \\
\hline 1.a. What qualifications (skills, education, and \\
experience) do institutions require for resident directors? \\
$\begin{array}{l}\text { 1.b. What types of training are resident directors } \\
\text { provided? }\end{array}$ \\
\hline $\begin{array}{l}\text { 2. How likely is a resident director to be retained based } \\
\text { on the institution's organizational culture? }\end{array}$ \\
\hline $\begin{array}{l}\text { 2.a. What types of professional development } \\
\text { opportunities exist? }\end{array}$ \\
\hline 2.b. What type of mentoring occurs? \\
\hline 2.c. What types of rewards and benefits are offered? \\
\hline $\begin{array}{l}\text { 3. How do ACUHO-I best practices institutions compare } \\
\text { to WVU's HEPC peer institutions? }\end{array}$ \\
\hline
\end{tabular}


Table 4

Administrators' Surveys - Research Questions and Corresponding Survey Questions

\begin{tabular}{|c|c|}
\hline Research Question & Corresponding Survey Questions \\
\hline $\begin{array}{l}\text { 1. How well prepared are resident directors to assume } \\
\text { their demanding leadership role? }\end{array}$ & $11-12$ \\
\hline $\begin{array}{l}\text { 1.a. What qualifications (skills, education, and } \\
\text { experience) do institutions require for resident directors? }\end{array}$ & $\begin{array}{c}13-14 \text { (skills) } \\
15-16 \text { (education) } \\
17-20,40 \text { (experience) }\end{array}$ \\
\hline $\begin{array}{l}\text { 1.b. What types of training are resident directors } \\
\text { provided? }\end{array}$ & $23-37$ \\
\hline $\begin{array}{l}\text { 2. How likely is a resident director to be retained based } \\
\text { on the institution's organizational culture? }\end{array}$ & $38-39,41-46$ \\
\hline $\begin{array}{l}\text { 2.a. What types of professional development } \\
\text { opportunities exist? }\end{array}$ & $47-48$ \\
\hline 2.b. What type of mentoring occurs? & $49-52$ \\
\hline 2.c. What types of rewards and benefits are offered? & $53-58$ \\
\hline $\begin{array}{l}\text { 3. How do ACUHO-I best practices institutions compare } \\
\text { to WVU's HEPC peer institutions? }\end{array}$ & $1-59$ \\
\hline
\end{tabular}

The researcher organized the data from the study into sets in a database. The researcher removed any identifiable information of the respondents to ensure confidentiality. There was no correlation made with respondents and their institutions to ensure additional confidentiality. 


\section{Timeframe}

After the dissertation committee approved the researcher's defense of the dissertation prospectus, the researcher applied to the West Virginia University's Institutional Review Board (IRB) for research approval. Once approval from West Virginia University's IRB was obtained, a pilot study was conducted by sending a letter (Appendix C) and questionnaires (Appendices A \& B) to the pilot study group at West Virginia University. Following completion of the pilot study, recommendations were utilized to make appropriate changes to the survey instruments. The researcher then sent cover letters (Appendix D) and questionnaires (Appendices A \& B) to resident directors and residence life administrators at the designated institutions in October, 2011. Email follow-up reminders were sent to non-responsive participants after the second week following the initial solicitation of the surveys. After collection of the survey data was complete, the researcher analyzed the results of the study so that she could present the findings and recommendations to the dissertation committee.

\section{Limitations of this Study}

1. Level of preparation was measured by self-reporting of the participants; therefore the study is limited by the accuracy of the respondents' self-perceptions.

2. There were 18 institutions utilized for this study. Eleven institutions were identified as having best practices in the recruitment and/or retention of resident directors by an Association of College \& University Housing Officer s- International (ACUHO-I) Commissioned Research Program (Ellett, et. al., 2008). As a result, the findings may not be generalizable to other institutions. 


\section{Background of the Researcher}

The researcher is a non-traditional, first-generation college student. She earned a Regents Bachelor of Arts degree from West Virginia University in 2001 and earned a Masters in Public Administration from West Virginia University in 2004. The researcher has worked at West Virginia University for the past 19 years and has spent the last eight years in West Virginia University's Department of Residential Education. She currently serves as the Director of the Residential Education program. The researcher has completed her coursework and passed her competency examinations. The researcher's goal is to fulfill her life-long dream and receive the Doctorate in Educational Leadership from West Virginia University. 


\section{Chapter Four}

\section{Results}

\section{Population and Participant Response}

The population for this study consisted of 362 residence life staff members (245 resident directors and 117 residence life administrators) who were listed as staff members at 18 institutions. Eleven institutions were identified as having best practices in the recruitment and/or retention of resident directors by the Association of College \& University Housing Officers International (ACUHO-I) Commissioned Research Program (Ellett, et. al., 2008) (see Table 1) and seven institutions were selected from West Virginia University's (WVU) Higher Education Policy Commission (HEPC) peer institutions (HEPC Peers, 2011) (see Table 2).

A total of $148(40 \%)$ residence life staff members (102 resident directors and 46 residence life administrators) responded to the survey. There were four different surveys utilized: (1) resident directors at designated West Virginia University Higher Education Peer institutions (RD HEPC), (2) resident directors at institutions designated by the Association of College and University Housing Officers - International as best practice institutions (RD ACUHOI), (3) administrators at designated West Virginia University Higher Education Peer Institutions (Admin. HEPC), and (4) administrators at institutions designated by the Association of College and University Housing Officers - International as best practice institutions (Admin. ACUHOI). The 66 survey questions were identical in Survey 1 (RD HEPC) and Survey 2 (RD ACUHOI). The 59 survey questions were identical in Survey 3 (Admin. HEPC) and Survey 4 (Admin. ACUHOI). The response rate for each survey instrument ranged from $30 \%$ to $50 \%$ as shown in Table 5. 
Table 5

Population and Respondents of HEPC and ACUHO-I Institutions

\begin{tabular}{lccccccc}
\hline Participants & RD & RD & RD & Admin. & Admin. & Admin. & $\begin{array}{c}\text { Survey } \\
\text { Totals }\end{array}$ \\
\hline Population & 132 & 113 & 245 & 52 & 65 & 117 & 362 \\
Respondents & 67 & 35 & 102 & 26 & 20 & 46 & 148 \\
Percentage & 49.0 & 30.0 & 41.6 & 50.0 & 30.0 & 39.3 & 40.8 \\
\hline
\end{tabular}

\section{Demographics and Participant Information}

Resident directors were asked 11 demographic/participant information questions.

Administrators were asked ten demographic/participant information questions.

Table 6 reflects that the majority of resident director respondents were female with $58 \%$ $(n=58)$ in this category. $41 \%(n=41)$ were male and $1 \%(n=1)$ was transgender. The HEPC and ACUHO-I survey results were similar in that the majority of respondents were female.

Table 6

Gender of Resident Director Participants

\begin{tabular}{|c|c|c|c|c|c|c|}
\hline Gender & $\begin{array}{c}\text { RD } \\
\text { HEPC } \\
\mathrm{N}\end{array}$ & $\begin{array}{c}\text { RD } \\
\text { HEPC } \\
\%\end{array}$ & $\begin{array}{c}\mathrm{RD} \\
\text { ACUHOI } \\
\mathrm{N}\end{array}$ & $\begin{array}{c}\text { RD } \\
\text { ACUHOI } \\
\%\end{array}$ & $\begin{array}{c}\text { RD } \\
\text { Total } \\
\mathrm{N}\end{array}$ & $\begin{array}{c}\text { RD } \\
\text { Total } \\
\%\end{array}$ \\
\hline Male & 26 & 40.0 & 15 & 42.9 & 41 & 41.0 \\
\hline Female & 38 & 58.5 & 20 & 57.1 & 58 & 58.0 \\
\hline Transgender & 1 & 1.5 & 0 & 0 & 1 & 1.0 \\
\hline Total Answered & 65 & & 35 & & 100 & \\
\hline Skipped Question & 2 & & 0 & & 2 & \\
\hline
\end{tabular}


Table 7 reflects that majority of administrators respondents were female with $55.6 \%$ $(n=25)$ in this category. The HEPC and ACUHO-I survey results were similar in that the majority of administrator were female.

Table 7

Gender of Administrator Participants

\begin{tabular}{lcccccc}
\hline Gender & $\begin{array}{c}\text { Admin. } \\
\text { HEPC } \\
\text { N }\end{array}$ & $\begin{array}{c}\text { Admin. } \\
\text { HEPC } \\
\%\end{array}$ & $\begin{array}{c}\text { Admin. } \\
\text { ACUHOI } \\
\text { Male }\end{array}$ & $\begin{array}{c}\text { Admin. } \\
\text { ACUHOI } \\
\%\end{array}$ & $\begin{array}{c}\text { Admin. } \\
\text { Total } \\
\text { N }\end{array}$ & $\begin{array}{c}\text { Admin. } \\
\text { Total } \\
\%\end{array}$ \\
Female & 11 & 42.3 & 9 & 47.4 & 20 & 44.4 \\
Transgender & 15 & 57.7 & 10 & 52.6 & 25 & 55.6 \\
Total Answered & 26 & 0.0 & 0 & 0.0 & 0 & 0.0 \\
Skipped Question & & & 19 & & 45 & \\
& & & 1 & & 1 & \\
\hline
\end{tabular}

Table 8 reflects that the majority of the resident director respondents were between the ages of $26-30$ with $43.5 \%(n=44)$ in this category. The HEPC and ACUHO-I survey results were not similar in that the majority of HEPC respondents were between the ages of 26-30, and the majority of ACUHO-I respondents were between the ages of 20-25.

Table 8 Age of Resident Director Participants

\begin{tabular}{lcccccc}
\hline Age & RD & RD & RD & RD & RD & RD \\
& HEPC & HEPC & ACUHOI & ACUHOI & Total & Total \\
& N & $\%$ & N & $\%$ & N & $\%$ \\
\hline Under 20 & 0 & 0.0 & 0 & 0.0 & 0 & 0.0 \\
$20-25$ & 17 & 25.8 & 16 & 45.7 & 33 & 32.7 \\
& & & & & & (continued)
\end{tabular}




\begin{tabular}{|c|c|c|c|c|c|c|}
\hline Age & $\begin{array}{c}\text { RD } \\
\text { HEPC } \\
N\end{array}$ & $\begin{array}{c}\mathrm{RD} \\
\mathrm{HEPC} \\
\%\end{array}$ & $\begin{array}{c}\mathrm{RD} \\
\text { ACUHOI } \\
\mathrm{N}\end{array}$ & $\begin{array}{c}\text { RD } \\
\text { ACUHOI } \\
\%\end{array}$ & $\begin{array}{c}\mathrm{RD} \\
\text { Total } \\
\mathrm{N}\end{array}$ & $\begin{array}{c}\mathrm{RD} \\
\text { Total } \\
\%\end{array}$ \\
\hline $26-30$ & 30 & 45.5 & 14 & 40.0 & 44 & 43.5 \\
\hline $31-35$ & 14 & 21.2 & 4 & 11.4 & 18 & 17.8 \\
\hline Over 35 & 5 & 7.6 & 1 & 2.9 & 6 & 6.0 \\
\hline Total Answered & 66 & & 35 & & 101 & \\
\hline Skipped Question & 1 & & 0 & & 1 & \\
\hline
\end{tabular}

Table 9 reflects that the majority of administrator respondents were between the ages of 30-35 with $34.8 \%(\mathrm{n}=16)$ in this category. $30.4 \%(\mathrm{n}=14)$ were over the age of 45 . The majority of the HEPC respondents were between the ages of $30-35$ with $42.3 \%(n=11)$ in this category while of the majority of ACUHO-I respondents were over the age of 45 with $30 \%(n=6)$ in this category.

Table 9

Age of Administrator Participants

\begin{tabular}{lcccccc}
\hline Age & $\begin{array}{c}\text { Admin. } \\
\text { HEPC } \\
\mathrm{N}\end{array}$ & $\begin{array}{c}\text { Admin. } \\
\text { HEPC } \\
\%\end{array}$ & $\begin{array}{c}\text { Admin. } \\
\text { ACUHOI } \\
\mathrm{N}\end{array}$ & $\begin{array}{c}\text { Admin. } \\
\text { ACUHOI } \\
\%\end{array}$ & $\begin{array}{c}\text { Admin. } \\
\text { Total } \\
\mathrm{N}\end{array}$ & $\begin{array}{c}\text { Admin. } \\
\text { Total } \\
\%\end{array}$ \\
\hline Under 30 & 1 & 3.8 & 0 & 0.0 & 1 & 2.2 \\
$30-35$ & 11 & 42.3 & 5 & 25.0 & 16 & 34.8 \\
$36-40$ & 1 & 3.8 & 4 & 20.0 & 5 & 10.9 \\
$41-45$ & 5 & 19.2 & 5 & 25.0 & 10 & 21.7 \\
Over 45 & 8 & 30.8 & 6 & 30.0 & 14 & 30.4 \\
Total Answered & 26 & & 20 & & 46 & \\
Skipped Question & 0 & & 0 & & 0 & \\
\hline
\end{tabular}


Table 10 reflects that the majority of resident director respondents were

White/Caucasian/European American with 76.2\% $(n=77)$ in this category. The HEPC and ACUHO-I survey results were similar in that the majority of respondents were

White/Caucasian/European American.

Table 10

Ethnic Affiliation of Resident Director Participants

\begin{tabular}{|c|c|c|c|c|c|c|}
\hline Ethnic Affiliation & $\begin{array}{c}\text { RD } \\
\text { HEPC } \\
\mathrm{N}\end{array}$ & $\begin{array}{c}\text { RD } \\
\text { HEPC } \\
\%\end{array}$ & $\begin{array}{c}\text { RD } \\
\text { ACUHOI } \\
\mathrm{N}\end{array}$ & $\begin{array}{c}\text { RD } \\
\text { ACUHOI } \\
\%\end{array}$ & $\begin{array}{c}\mathrm{RD} \\
\text { Total } \\
\mathrm{N}\end{array}$ & $\begin{array}{c}\mathrm{RD} \\
\text { Total } \\
\%\end{array}$ \\
\hline African American/Black & 11 & 16.7 & 6 & 17.1 & 17 & 16.8 \\
\hline $\begin{array}{l}\text { Asian American } \\
\text { Pacific Islander }\end{array}$ & 4 & 6.1 & 0 & 0.0 & 4 & 4.0 \\
\hline $\begin{array}{l}\text { Hispanic American/ } \\
\text { Latino/Chicano }\end{array}$ & 1 & 1.5 & 0 & 0.0 & 1 & 1.0 \\
\hline Native American/Tribal & 0 & 0.0 & 0 & 0.0 & 0 & 0.0 \\
\hline Affiliation & & & & & & \\
\hline $\begin{array}{l}\text { White/Caucasian/ } \\
\text { European American }\end{array}$ & 49 & 74.2 & 28 & 80.0 & 77 & 76.2 \\
\hline Multi-Racial & 0 & 0.0 & 0 & 0.0 & 0 & 0.0 \\
\hline $\begin{array}{l}\text { Other/Prefer Not to } \\
\text { Answer }\end{array}$ & 1 & 1.5 & 1 & 2.9 & 2 & 2.0 \\
\hline Total Answered & 66 & 100 & 35 & 100 & 101 & 100 \\
\hline Skipped Question & 1 & & 0 & & 1 & \\
\hline
\end{tabular}

Table 11 reflects that the majority of administrator respondents were White/Caucasian/European American with 91.1\% $(n=41)$ in this category. The HEPC and 
ACUHO-I survey results were similar in that the majority of respondents were

White/Caucasian/European American.

Table 11

Ethnic Affiliation of Administrator Participants

\begin{tabular}{|c|c|c|c|c|c|c|}
\hline Ethnic Affiliation & $\begin{array}{c}\text { Admin. } \\
\text { HEPC } \\
\mathrm{N}\end{array}$ & $\begin{array}{c}\text { Admin. } \\
\text { HEPC } \\
\%\end{array}$ & $\begin{array}{c}\text { Admin. } \\
\text { ACUHOI } \\
\mathrm{N} \\
\end{array}$ & $\begin{array}{c}\text { Admin. } \\
\text { ACUHOI } \\
\% \\
\end{array}$ & $\begin{array}{c}\text { Admin. } \\
\text { Total } \\
\mathrm{N}\end{array}$ & $\begin{array}{c}\text { Admin. } \\
\text { Total } \\
\%\end{array}$ \\
\hline African American/Black & 1 & 4.0 & 2 & 10.0 & 3 & 6.7 \\
\hline $\begin{array}{l}\text { Asian American } \\
\text { Pacific Islander }\end{array}$ & 0 & 0.0 & 0 & 0.0 & 0 & 0.0 \\
\hline $\begin{array}{l}\text { Hispanic American/ } \\
\text { Latino/Chicano }\end{array}$ & 1 & 4.0 & 0 & 0.0 & 1 & 2.2 \\
\hline $\begin{array}{l}\text { Native American/Tribal } \\
\text { Affiliation }\end{array}$ & 0 & 0.0 & 0 & 0.0 & 0 & 0.0 \\
\hline $\begin{array}{l}\text { White/Caucasian/European } \\
\text { American }\end{array}$ & 23 & 92.0 & 18 & 90.0 & 41 & 91.1 \\
\hline Multi-Racial & 0 & 0.0 & 0 & 0.0 & 0 & 0.0 \\
\hline Other/Prefer Not to Answer & 0 & 0.0 & 0 & 0.0 & 0 & 0.0 \\
\hline Total Answered & 25 & & 20 & & 45 & \\
\hline Skipped Question & 1 & & & & 1 & \\
\hline
\end{tabular}

Table 12 reflects that the majority of resident director respondents did not have a live-in spouse or partner with $71.2 \%(\mathrm{n}=72)$ in this category. The HEPC and ACUHO-I survey results were similar in that the majority of respondents did not have a live-in spouse or partner. 
Table 12

Live-in Spouse or Partner Status

\begin{tabular}{|c|c|c|c|c|c|c|}
\hline $\begin{array}{l}\text { Live-In Spouse or } \\
\text { Partner }\end{array}$ & $\begin{array}{c}\text { RD } \\
\text { HEPC } \\
\mathrm{N}\end{array}$ & $\begin{array}{c}\text { RD } \\
\text { HEPC } \\
\% \\
\end{array}$ & $\begin{array}{c}\mathrm{RD} \\
\text { ACUHOI } \\
\mathrm{N}\end{array}$ & $\begin{array}{c}\text { RD } \\
\text { ACUHOI } \\
\% \\
\end{array}$ & $\begin{array}{c}\text { RD } \\
\text { Total } \\
\mathrm{N}\end{array}$ & $\begin{array}{c}\text { RD } \\
\text { Total } \\
\% \\
\end{array}$ \\
\hline Yes & 23 & 34.8 & 6 & 17.1 & 29 & 28.8 \\
\hline No & 43 & 65.2 & 29 & 82.9 & 72 & 71.2 \\
\hline Total Answered & 66 & 100 & 35 & 100 & 101 & \\
\hline Skipped Question & 1 & & 0 & & 1 & \\
\hline
\end{tabular}

Respondents to the resident director survey were asked to list their official titles. The main purpose of this question was to determine the titles most commonly used by those serving as resident directors. Table 13 reflects that the majority held the title of Resident (Residence) Director, Resident (Residence) Hall Director or Hall Director with 49.5\% $(n=50)$ in this category. The HEPC and ACUHO-I survey results were similar in that the majority of respondents held the title of Resident (Residence) Director, Resident (Residence) Hall Director or Hall Director.

Table 13

Resident Director Survey Participant Titles

\begin{tabular}{lcccccc}
\hline Title & RD & RD & RD & RD & RD & RD \\
& HEPC & HEPC & ACUHOI & ACUHOI & Total & Total \\
& N & $\%$ & N & $\%$ & N & $\%$ \\
\hline Resident (Residence) & 38 & 57.6 & 12 & 34.3 & 50 & 49.5 \\
Director/Resident (Residence) & & & & & & \\
Hall Director/Hall Director & & & & & &
\end{tabular}

(continued) 


\begin{tabular}{lcccccc}
\hline Title & RD & RD & RD & RD & RD & RD \\
& $\begin{array}{c}\text { HEPC } \\
\text { N }\end{array}$ & $\begin{array}{c}\text { HEPC } \\
\text { \% }\end{array}$ & $\begin{array}{c}\text { ACUHOI } \\
\text { ACUHOI }\end{array}$ & $\begin{array}{c}\text { Total } \\
\%\end{array}$ & $\begin{array}{c}\text { Total } \\
\%\end{array}$ \\
\hline $\begin{array}{l}\text { Residence Life } \\
\begin{array}{l}\text { Coordinator/Residence Hall } \\
\text { Coordinator/Hall }\end{array}\end{array}$ & 18 & 27.3 & 7 & 20.0 & 25 & 24.8 \\
$\begin{array}{l}\text { Coordinator/Residential } \\
\text { Learning Coordinator/Area } \\
\text { Coordinator }\end{array}$ & & & & & & \\
$\begin{array}{l}\text { Assistant Resident Hall } \\
\text { Director/Coordinator }\end{array}$ & 2 & 3.0 & 9 & 25.7 & 11 & 10.9 \\
$\begin{array}{l}\text { Graduate/Doctoral Student } \\
\text { Director/Coordinator }\end{array}$ & 1 & 1.5 & 3 & 8.6 & 4 & 3.9 \\
Misc. Other Titles & & & & & & \\
Total Answered & 7 & 10.6 & 4 & 11.4 & 11 & 10.9 \\
\hline
\end{tabular}

Respondents to the residence life administrator survey were asked to list their titles. The main purpose of this question was to understand more about the respondents. Table 14 reflects that the majority held the title of Assistant or Associate Director with $73.9 \%(n=34)$ in this category. The HEPC and ACUHO-I survey results were similar in that the majority of respondents held the title of Assistant or Associate director.

Table 14

Administrator Survey Participant Titles

\begin{tabular}{|c|c|c|c|c|c|c|}
\hline Title & $\begin{array}{c}\text { Admin. } \\
\text { HEPC } \\
\mathrm{N}\end{array}$ & $\begin{array}{c}\text { Admin. } \\
\text { HEPC } \\
\%\end{array}$ & $\begin{array}{c}\text { Admin. } \\
\text { ACUHOI } \\
\mathrm{N}\end{array}$ & $\begin{array}{c}\text { Admin. } \\
\text { ACUHOI } \\
\%\end{array}$ & $\begin{array}{c}\text { Admin. } \\
\text { Total } \\
\text { N }\end{array}$ & $\begin{array}{c}\text { Admin. } \\
\text { Total } \\
\%\end{array}$ \\
\hline $\begin{array}{l}\text { Assistant/Associate } \\
\text { Director }\end{array}$ & 21 & 80.8 & 13 & 65.0 & 34 & $\begin{array}{c}73.9 \\
\text { continued }\end{array}$ \\
\hline
\end{tabular}




\begin{tabular}{lcccccc}
\hline Title & $\begin{array}{c}\text { Admin. } \\
\text { HEPC } \\
\end{array}$ & $\begin{array}{c}\text { Admin. } \\
\text { HEPC }\end{array}$ & $\begin{array}{c}\text { Admin. } \\
\text { ACUHOI }\end{array}$ & $\begin{array}{c}\text { Admin. } \\
\text { ACUHOI }\end{array}$ & $\begin{array}{c}\text { Admin. } \\
\text { Total }\end{array}$ & $\begin{array}{c}\text { Admin. } \\
\text { Total }\end{array}$ \\
$\begin{array}{l}\text { Director/Executive } \\
\text { Director }\end{array}$ & 3 & 11.6 & 3 & 15.0 & 6 & 13.1 \\
Dean of Students & 0 & 0.0 & 1 & 5.0 & 1 & 2.2 \\
Associate Vice President & 1 & 3.8 & 1 & 5.0 & 2 & 4.3 \\
Misc. Other Titles & 1 & 3.8 & 2 & 10.0 & 3 & 6.5 \\
Total Answered & 26 & & 20 & & 46 & \\
\hline
\end{tabular}

Tables 15 reflects that the majority of the resident directors had either "2 Years" or "5 Years or More" experience as a resident director with 29.6\% $(\mathrm{n}=26)$ in both of these categories. The HEPC and ACUHO-I survey results were similar in that the majority of respondents for both surveys had the equivalent percentage in either " 2 Years" or "5 Years or More" resident director experience.

Table 15

Participants Years as a Resident Director

\begin{tabular}{lcccccc}
\hline Years & RD & RD & RD & RD & RD & RD \\
& HEPC & HEPC & ACUHOI & ACUHOI & Total & Total \\
& N & $\%$ & N & $\%$ & N & 0 \\
\hline 1 Year or Less & 7 & 11.7 & 5 & 17.9 & 12 & 13.6 \\
2 Years & 16 & 26.7 & 10 & 35.7 & 26 & 29.6 \\
3 Years & 12 & 20.0 & 3 & 10.7 & 15 & 17.0 \\
4 Years & 9 & 15.0 & 0 & 0.0 & 9 & 10.2 \\
5 Years or More & 16 & 26.7 & 10 & 35.7 & 26 & 29.6 \\
& & & & & & (continued)
\end{tabular}




\begin{tabular}{|c|c|c|c|c|c|c|}
\hline Years & $\begin{array}{c}\mathrm{RD} \\
\mathrm{HEPC} \\
\mathrm{N}\end{array}$ & $\begin{array}{c}\text { RD } \\
\text { HEPC } \\
\%\end{array}$ & $\begin{array}{c}\text { RD } \\
\text { ACUHOI } \\
\mathrm{N}\end{array}$ & $\begin{array}{c}\text { RD } \\
\text { ACUHOI } \\
\%\end{array}$ & $\begin{array}{c}\mathrm{RD} \\
\text { Total } \\
\mathrm{N}\end{array}$ & $\begin{array}{c}\mathrm{RD} \\
\text { Total } \\
\%\end{array}$ \\
\hline Total Answered & 60 & & 28 & & 88 & \\
\hline Skipped Question & 7 & & 7 & & 14 & \\
\hline
\end{tabular}

Table 16 reflects that the majority of the administrators had " 5 Years or More" residence life experience with $92.9 \%(\mathrm{n}=39)$ in this category. The HEPC and ACUHO-I survey results were similar in that the majority of respondents had "5 Years or More" administrative experience.

Table 16

Participants Years as a Residence Life Administrator

\begin{tabular}{lcccccc}
\hline Years & $\begin{array}{c}\text { Admin. } \\
\text { HEPC }\end{array}$ & $\begin{array}{c}\text { Admin. } \\
\text { HEPC } \\
\%\end{array}$ & $\begin{array}{c}\text { Admin. } \\
\text { ACUHOI }\end{array}$ & $\begin{array}{c}\text { Admin } \\
\text { ACUHOI } \\
\%\end{array}$ & $\begin{array}{c}\text { Total } \\
\mathrm{N}\end{array}$ & $\begin{array}{c}\text { Total } \\
\%\end{array}$ \\
\hline 1 Year or Less & 0 & 0.0 & 0 & 0.0 & 0 & 0.0 \\
2 Years & 0 & 0.0 & 0 & 0.0 & 0 & 0.0 \\
3 Years & 0 & 0.0 & 0 & 0.0 & 0 & 0.0 \\
4 Years & 3 & 12.5 & 0 & 0.0 & 3 & 7.1 \\
5 Years or More & 21 & 87.5 & 18 & 100.0 & 39 & 92.9 \\
Total Answered & 24 & & 18 & & 42 & \\
Skipped Question & 2 & & 2 & & 4 & \\
\hline
\end{tabular}

Tables 17 reflects that the majority of the resident directors had " 2 Years" experience at their current institution with $29.6 \%(\mathrm{n}=26)$ in this category. $28.4 \%(\mathrm{n}=25)$ had "1 Year or Less" experience at their current institution. The majority of the HEPC respondents had "1 Year or 
Less" experience with $33.3 \%(\mathrm{n}=20)$ in this category while the ACUHO-I respondents had "2 Years" experience with $42.9 \%(\mathrm{n}=12)$ in this category.

Table 17

Participants Years as a Resident Director at Current Institution

\begin{tabular}{lcccccc}
\hline Years & RD & RD & RD & RD & RD & RD \\
& HEPC & HEPC & ACUHOI & ACUHOI & Total & $\begin{array}{c}\text { Total } \\
\%\end{array}$ \\
& N & $\%$ & N & $\%$ & N & $\%$ \\
1 Year or Less & 20 & 33.3 & 5 & 17.9 & 25 & 28.4 \\
2 Years & 14 & 23.3 & 12 & 42.9 & 26 & 29.6 \\
3 Years & 12 & 20.0 & 3 & 10.7 & 15 & 17.0 \\
4 Years & 7 & 11.7 & 1 & 3.6 & 8 & 9.1 \\
5 Years or More & 7 & 11.7 & 7 & 25.0 & 14 & 15.9 \\
Total Answered & 60 & & 28 & & 88 & \\
Skipped Question & 7 & & 7 & & 14 & \\
\hline
\end{tabular}

Table 18 reflects that the majority of the administrators had "5 Years or More" experience at their current institution with $78.6 \%(\mathrm{n}=33)$ in this category. The HEPC and ACUHO-I survey results were similar in that the majority of respondents had "5 Years or More" experience at their current institution.

Table 18

Participants Years as a Residence Life Administrator at Current Institution

\begin{tabular}{lcccccc}
\hline Years & Admin. & Admin. & Admin. & Admin & Total & Total \\
& HEPC & HEPC & ACUHOI & ACUHOI & $\mathrm{N}$ & $\%$ \\
& $\mathrm{~N}$ & $\%$ & $\mathrm{~N}$ & $\%$ & & \\
\hline 1 Year or Less & 1 & 4.2 & 0 & 0.0 & 1 & 2.4 \\
& & & & & & (continued)
\end{tabular}




\begin{tabular}{lcccccc}
\hline Years & $\begin{array}{c}\text { Admin. } \\
\text { HEPC } \\
\text { N }\end{array}$ & $\begin{array}{c}\text { Admin. } \\
\text { HEPC } \\
\%\end{array}$ & $\begin{array}{c}\text { Admin. } \\
\text { ACUHOI } \\
\text { N }\end{array}$ & $\begin{array}{c}\text { Admin } \\
\text { ACUHOI } \\
\%\end{array}$ & $\begin{array}{c}\text { Total } \\
\mathrm{N}\end{array}$ & $\begin{array}{c}\text { Total } \\
\%\end{array}$ \\
\hline Years & 0 & 0.0 & 0 & 0.0 & 0 & 0.0 \\
4 Years & 2 & 8.3 & 1 & 5.6 & 3 & 7.1 \\
5 Years & 4 & 16.7 & 1 & 5.6 & 5 & 11.9 \\
Total Answered & 24 & & 18 & 88.9 & 33 & 78.6 \\
Skipped Question & 2 & & 2 & & 42 & \\
\hline
\end{tabular}

Table 19 reflects that the greatest percentage of students living in the residence halls were "Mostly Freshmen" with 45.8\% ( $\mathrm{n}=60$ ) in this category. The HEPC and ACUHO-I results were not similar in that the HEPC institutions had "Mostly Freshmen" in the residence halls with $54.8 \%(\mathrm{n}=46)$ in this category while the ACUHO-I institutions had "Mostly Freshmen and Upper-class" students with $53.2 \%(\mathrm{n}=25)$ in this category.

Table 19

Academic Class Rank of Students in the Residence Halls

\begin{tabular}{lcccccc}
\hline Class Rank & $\begin{array}{c}\text { HEPC } \\
\text { N }\end{array}$ & $\begin{array}{c}\text { HEPC } \\
\%\end{array}$ & $\begin{array}{c}\text { ACUHOI } \\
\text { N }\end{array}$ & $\begin{array}{c}\text { ACUHOI } \\
\%\end{array}$ & $\begin{array}{c}\text { Total } \\
\text { N }\end{array}$ & $\begin{array}{c}\text { Total } \\
\%\end{array}$ \\
\hline Mostly Freshmen & 46 & 54.8 & 14 & 29.8 & 60 & 45.8 \\
Mostly Upper-class & 15 & 17.8 & 8 & 17.0 & 23 & 17.6 \\
Freshmen/Upper-class & 23 & 27.4 & 25 & 53.2 & 48 & 36.6 \\
Total Answered & 84 & & 47 & & 131 & \\
Skipped Question & 9 & & 8 & & 17 & \\
& & & & & & \\
\hline
\end{tabular}


Table 20 reflects that the majority of students living in the residence halls were a mix of males and females with $93.1 \%(\mathrm{n}=121)$ in this category. The HEPC and ACUHO-I survey results were similar in that the majority of the institutions' residence hall population had a mix of male and female students.

Table 20

Gender of Residence Hall Students

\begin{tabular}{lcccccc}
\hline Gender & $\begin{array}{c}\text { HEPC } \\
\mathrm{N}\end{array}$ & $\begin{array}{c}\text { HEPC } \\
\%\end{array}$ & $\begin{array}{c}\text { ACUHOI } \\
\mathrm{N}\end{array}$ & $\begin{array}{c}\text { ACUHOI } \\
\%\end{array}$ & $\begin{array}{c}\text { Total } \\
\mathrm{N}\end{array}$ & $\begin{array}{c}\text { Total } \\
\%\end{array}$ \\
\hline Mostly Males & 4 & 4.7 & 2 & 4.3 & 6 & 4.6 \\
Mostly Females & 3 & 3.6 & 0 & 0.0 & 3 & 2.3 \\
Males/Females & 77 & 91.7 & 44 & 95.7 & 121 & 93.1 \\
Total Answered & 84 & & 46 & & 130 & \\
Skipped Question & 9 & & 9 & & 18 & \\
\hline
\end{tabular}

Table 21 reflects that the majority of resident directors are responsible for crisis management (96.9\%), supervision of para-professional staff $(93.0 \%)$, serving as a student conduct hearing officer (91.5\%), daily operation of the hall (89.2\%), student programming (88.5\%), and serving as a student organization advisor (80.0\%). Responses reflected that some resident directors held budget officer (64.6\%) and facilities management (57.7\%) responsibilities while even fewer were responsible for the instruction of a first-year seminar course (25.4\%) and supervision of professional staff $(17.7 \%) .13$ respondents indicated that there were other duties not listed. The other duties listed included departmental committee work, curriculum development, instructor of RA course or training instructor, and graduate assistant supervisor. The HEPC and ACUHO-I survey results were similar in the ranking of these duties. 
Table 21

Resident Director Responsibilities

\begin{tabular}{|c|c|c|c|c|c|c|}
\hline Responsibilities & $\begin{array}{c}\text { HEPC } \\
\mathrm{N}\end{array}$ & $\begin{array}{c}\mathrm{HEPC} \\
\% \\
\end{array}$ & $\begin{array}{c}\text { ACUHOI } \\
\mathrm{N}\end{array}$ & $\begin{array}{c}\text { ACUHOI } \\
\% \\
\end{array}$ & $\begin{array}{c}\text { Total } \\
\mathrm{N}\end{array}$ & $\begin{array}{c}\text { Total } \\
\%\end{array}$ \\
\hline Daily Hall Operations & 74 & 89.2 & 42 & 89.3 & 116 & 89.2 \\
\hline Student Programming & 76 & 91.5 & 39 & 82.9 & 115 & 88.5 \\
\hline $\begin{array}{l}\text { Supervision of Para- } \\
\text { professional staff }\end{array}$ & 78 & 94.0 & 43 & 91.5 & 121 & 93.0 \\
\hline $\begin{array}{l}\text { Supervision of } \\
\text { Professional Staff }\end{array}$ & 14 & 16.9 & 9 & 19.1 & 23 & 17.7 \\
\hline $\begin{array}{l}\text { Student Conduct Hearing } \\
\text { Officer }\end{array}$ & 75 & 90.4 & 44 & 93.6 & 119 & 91.5 \\
\hline Facilities Management & 48 & 57.9 & 27 & 57.4 & 75 & 57.7 \\
\hline Crisis Management & 82 & 98.8 & 44 & 93.6 & 126 & 96.9 \\
\hline $\begin{array}{l}\text { Instructor of First-Year } \\
\text { Course }\end{array}$ & 22 & 26.5 & 11 & 23.4 & 33 & 25.4 \\
\hline $\begin{array}{l}\text { Student Organization } \\
\text { Advisor }\end{array}$ & 61 & 73.5 & 43 & 91.5 & 104 & 80.0 \\
\hline Budget Officer & 58 & 69.9 & 26 & 55.3 & 84 & 64.6 \\
\hline Total Answered & 83 & & 47 & & 130 & \\
\hline Skipped Question & 10 & & 8 & & 18 & \\
\hline
\end{tabular}

Table 22 reflects that the majority of the resident directors supervise 8-15 RAs with $62.8 \%(n=81)$ in this category. The HEPC and ACUHO-I survey results were similar in that the majority of resident directors supervised 8-15 RAs. However, there was more variation in the number of RAs that the resident director supervised at HEPC institutions. They typically supervised more RAs than their ACUHO-I peers. 
Table 22

Number of Resident Assistants Supervised by Resident Directors

\begin{tabular}{lcccccc}
\hline No. of RAs & $\begin{array}{c}\text { HEPC } \\
\text { N }\end{array}$ & $\begin{array}{c}\text { HEPC } \\
\%\end{array}$ & $\begin{array}{c}\text { ACUHOI } \\
\text { N }\end{array}$ & $\begin{array}{c}\text { ACUHOI } \\
\%\end{array}$ & $\begin{array}{c}\text { Total } \\
\text { N }\end{array}$ & $\begin{array}{c}\text { Total } \\
\%\end{array}$ \\
\hline 8-15 RAs & 7 & 8.5 & 5 & 10.6 & 12 & 9.3 \\
16-20 RAs & 44 & 53.7 & 37 & 78.8 & 81 & 62.8 \\
21-25 RAs & 14 & 17.0 & 4 & 8.5 & 18 & 14.0 \\
More than 25 RAs & 10 & 12.2 & 0 & 0.0 & 10 & 7.7 \\
Varies Too Much & 4 & 3.7 & 0 & 0.0 & 3 & 2.3 \\
Total Answered & 82 & 4.9 & 1 & 2.1 & 5 & 3.9 \\
Skipped Question & 11 & & 47 & & 129 & \\
\end{tabular}

\section{Research Questions One and Three}

Research Question One asked "How well prepared are resident directors to assume their demanding leadership role?" This was further analyzed by asking "What qualifications (skills, education, and experience) do institutions require for resident directors?" and "What types of training are resident directors provided?".

Research Question Three asked "How do ACUHO-I best practice institutions compare to WVU's HEPC peer institutions?”

\section{Comparison of Level of Preparation}

Table 23 reflects that the majority of the resident directors felt they were "Adequately Prepared" when they were first hired with $44.8 \%(n=39)$ rating this category. The HEPC and 
ACUHO-I survey results were similar in that the majority of respondents felt "Adequately Prepared." However, it should be noted that ACUHO-I resident directors rated "Very Well Prepared" at a higher percentage rate (19.9\% higher) than their HEPC peers.

Table 23

Resident Directors' Rating of Level of Preparation First Hired

\begin{tabular}{|c|c|c|c|c|c|c|}
\hline Level of Preparation & $\begin{array}{c}\text { RD } \\
\text { HEPC } \\
\mathrm{N}\end{array}$ & $\begin{array}{c}\text { RD } \\
\text { HEPC } \\
\%\end{array}$ & $\begin{array}{c}\text { RD } \\
\text { ACUHOI } \\
\mathrm{N}\end{array}$ & $\begin{array}{c}\text { RD } \\
\text { ACUHOI } \\
\%\end{array}$ & $\begin{array}{c}\mathrm{RD} \\
\text { Total } \\
\mathrm{N}\end{array}$ & $\begin{array}{c}\text { RD } \\
\text { Total } \\
\%\end{array}$ \\
\hline Very Well Prepared & 3 & 5.1 & 7 & 25.0 & 10 & 11.5 \\
\hline Well Prepared & 21 & 35.6 & 9 & 32.1 & 30 & 34.5 \\
\hline Adequately Prepared & 28 & 47.5 & 11 & 39.3 & 39 & 44.8 \\
\hline Poorly Prepared & 4 & 6.8 & 1 & 3.6 & 5 & 5.7 \\
\hline Very Poorly Prepared & 3 & 5.1 & 0 & 0.0 & 3 & 3.5 \\
\hline Total Answered & 59 & & 28 & & 87 & \\
\hline Skipped Question & 8 & & 7 & & 15 & \\
\hline
\end{tabular}

Table 24 reflects that the majority of administrators felt that newly hired resident directors were "Adequately Prepared" with 57.1\% $(n=24)$ rating this category. The HEPC and ACUHO-I survey results were not similar in that the majority of HEPC respondents rated the newly hired resident directors as "Adequately Prepared" while ACUHO-I respondents rated newly hired resident directors equally as "Well Prepared" and "Adequately Prepared." 
Table 24

Administrators' Rating of Level of Preparation of Resident Directors First Hired

\begin{tabular}{|c|c|c|c|c|c|c|}
\hline Level of Preparation & $\begin{array}{c}\text { Admin. } \\
\text { HEPC } \\
\mathrm{N}\end{array}$ & $\begin{array}{c}\text { Admin. } \\
\text { HEPC } \\
\%\end{array}$ & $\begin{array}{c}\text { Admin. } \\
\text { ACUHOI } \\
\mathrm{N}\end{array}$ & $\begin{array}{c}\text { Admin. } \\
\text { ACUHOI } \\
\%\end{array}$ & $\begin{array}{c}\text { Admin. } \\
\text { Total } \\
\mathrm{N}\end{array}$ & $\begin{array}{c}\text { Admin. } \\
\text { Total } \\
\%\end{array}$ \\
\hline Very Well Prepared & 0 & 0.0 & 1 & 5.3 & 1 & 2.4 \\
\hline Well Prepared & 7 & 30.4 & 9 & 47.4 & 16 & 38.1 \\
\hline Adequately Prepared & 15 & 65.2 & 9 & 47.4 & 24 & 57.1 \\
\hline Poorly Prepared & 1 & 4.3 & 0 & 0.0 & 1 & 2.4 \\
\hline Very Poorly Prepared & 0 & 0.0 & 0 & 0.0 & 0 & 0.0 \\
\hline Total Answered & 23 & & 19 & & 42 & \\
\hline Skipped Question & 3 & & 1 & & 4 & \\
\hline
\end{tabular}

Table 25 reflects that the majority of resident directors felt "Very Well Prepared" at the time of the survey with $66.7 \%(n=58)$ rating this category. The HEPC and ACUHO-I survey results were similar in that the majority of respondents felt "Very Well Prepared."

Table 25

Resident Directors' Rating of Current Level of Preparation

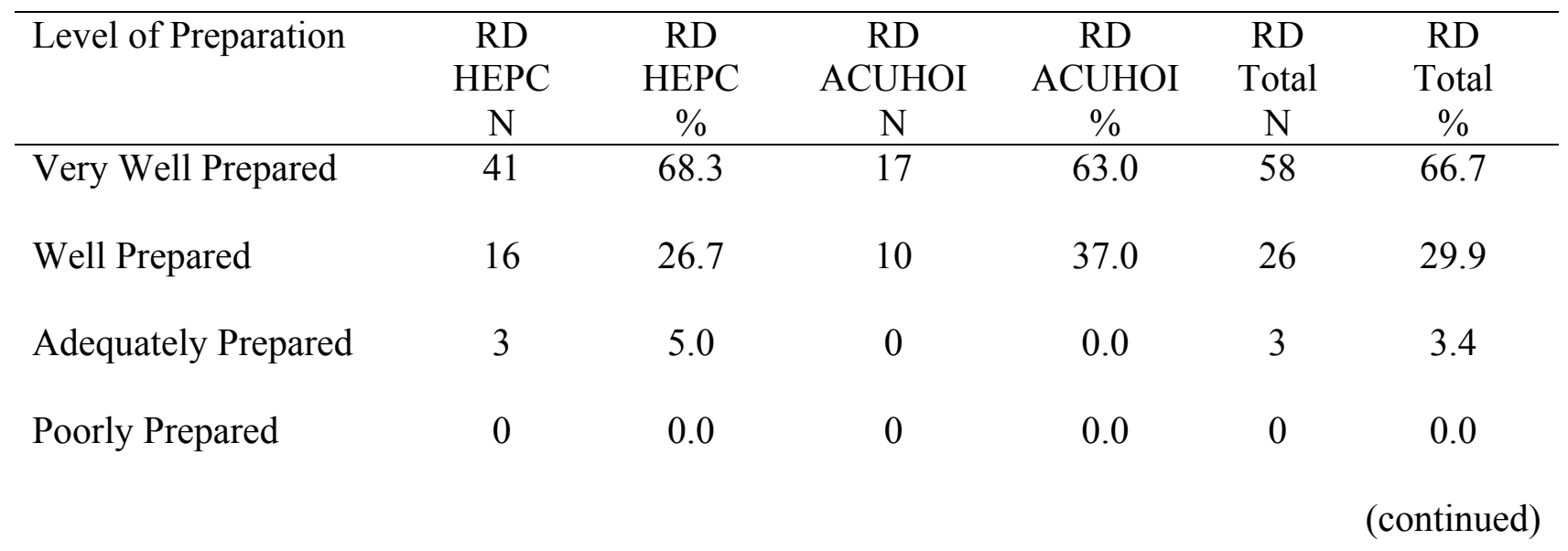




\begin{tabular}{lcccccc}
\hline Level of Preparation & RD & RD & RD & RD & RD & RD \\
& HEPC & HEPC & ACUHOI & ACUHOI & Total & $\begin{array}{c}\text { Total } \\
\%\end{array}$ \\
& N & $\%$ & N & $\%$ & N & $\%$ \\
\hline Very Poorly Prepared & 0 & 0.0 & 0 & 0.0 & 0 & 0.0 \\
Total Answered & 60 & & 27 & & 87 & \\
Skipped Question & 7 & & 8 & & 15 & \\
& & & & & & \\
\hline
\end{tabular}

Table 26 reflects that the majority of administrator felt resident directors were "Well Prepared" after at least one year experience with $57.1 \%(\mathrm{n}=24)$ rating this category. The HEPC and ACUHO-I survey results were similar in that the majority of respondents felt the resident directors were "Well Prepared" after at least one year experience.

Table 26

Administrators' Rating of RDs' Level of Preparation One Year or More Experience

\begin{tabular}{|c|c|c|c|c|c|c|}
\hline Preparedness & $\begin{array}{l}\text { Admin. } \\
\text { HEPC } \\
\text { N }\end{array}$ & $\begin{array}{c}\text { Admin. } \\
\text { HEPC } \\
\%\end{array}$ & $\begin{array}{l}\text { Admin. } \\
\text { ACUHOI } \\
\mathrm{N}\end{array}$ & $\begin{array}{l}\text { Admin. } \\
\text { ACUHOI } \\
\%\end{array}$ & $\begin{array}{c}\text { Admin. } \\
\text { Total } \\
\text { N }\end{array}$ & $\begin{array}{c}\text { Admin. } \\
\text { Total } \\
\%\end{array}$ \\
\hline Very Well Prepared & 7 & 30.4 & 9 & 47.4 & 16 & 38.1 \\
\hline Well Prepared & 14 & 60.9 & 10 & 52.6 & 24 & 57.1 \\
\hline Adequately Prepared & 2 & 8.7 & 0 & 0.0 & 2 & 4.8 \\
\hline Poorly Prepared & 0 & 0.0 & 0 & 0.0 & 0 & 0.0 \\
\hline Very Poorly Prepared & 0 & 0.0 & 0 & 0.0 & 0 & 0.0 \\
\hline Total Answered & 23 & & 19 & & 42 & \\
\hline Skipped Question & 3 & & 1 & & 4 & \\
\hline
\end{tabular}




\section{Comparison of Skills}

Resident directors were asked to rate the importance of skills needed to be a resident director. Table 27 reflects that the following skills were rated "Very Important" by at least 80\% of the respondents: Communication (88.6\%) and Interpersonal (84.1\%). Tables 28 and 29 reflect that HEPC and ACUHO-I survey results were similar in that "Communication" and "Interpersonal" skills were rated "Very Important" by at least $80 \%$ of respondents. HEPC resident directors included "Time Management" as a "Very Important" skill while ACUHO-I resident directors included "Leadership" as "Very Important" in the $80 \%$ or more respondent rating.

Table 27

HEPC \& ACUHO-I Resident Directors’ Rating of Level of Importance of Skills

\begin{tabular}{|c|c|c|c|c|c|c|}
\hline Skills & $\begin{array}{c}\text { Very } \\
\text { Important } \\
\%(N)\end{array}$ & $\begin{array}{c}\text { Somewhat } \\
\text { Important } \\
\%(\mathrm{~N})\end{array}$ & $\begin{array}{c}\text { Neutral } \\
\%(N)\end{array}$ & $\begin{array}{c}\text { Somewhat } \\
\text { Unimportant } \\
\%(\mathrm{~N})\end{array}$ & $\begin{array}{c}\text { Unimportant } \\
\%(N)\end{array}$ & $\begin{array}{c}\text { Response } \\
\text { Count }\end{array}$ \\
\hline Interpersonal & $84.1(74)$ & $14.8(13)$ & $1.1(1)$ & $0.0(0)$ & $0.0(0)$ & 88 \\
\hline Leadership & $73.9(65)$ & $22.7(20)$ & $2.3(2)$ & $0.0(0)$ & $0.0(0)$ & 87 \\
\hline $\begin{array}{l}\text { Personnel } \\
\text { Management }\end{array}$ & $65.9(58)$ & $34.1(30)$ & $0.0(0)$ & $0.0(0)$ & $0.0(0)$ & 88 \\
\hline Communication & $88.6(78)$ & $11.4(10)$ & $0.0(0)$ & $0.0(0)$ & $0.0(0)$ & 88 \\
\hline Time Management & $76.1(67)$ & $20.5(18)$ & $0.0(0)$ & $3.4(3)$ & $0.0(0)$ & 88 \\
\hline $\begin{array}{l}\text { Mentoring/ } \\
\text { Counseling }\end{array}$ & $68.2(60)$ & $28.4(25)$ & $2.3(2)$ & $1.1(1)$ & $0.0(0)$ & 88 \\
\hline Problem Solving & $75.0(66)$ & $25.0(22)$ & $0.0(0)$ & $0.0(0)$ & $0.0(0)$ & 88 \\
\hline Conflict Resolution & $72.7(64)$ & $26.1(23)$ & $0.0(0)$ & $1.1(1)$ & $0.0(0)$ & 88 \\
\hline Computer & $36.4(32)$ & $45.4(40)$ & $15.9(14)$ & $1.1(1)$ & $0.0(0)$ & 87 \\
\hline
\end{tabular}


Table 28 reflects that the following skills were rated "Very Important" by at least $80 \%$ of the HEPC respondents: "Communication" (86.7\%), "Interpersonal" (80\%), and "Time Management" (80\%).

Table 28

HEPC Resident Directors' Rating of Level of Importance of Skills

\begin{tabular}{|c|c|c|c|c|c|c|}
\hline Skills & $\begin{array}{c}\text { Very } \\
\text { Important } \\
\mathrm{N}(\%) \\
\end{array}$ & $\begin{array}{c}\text { Somewhat } \\
\text { Important } \\
\mathrm{N}(\%) \\
\end{array}$ & $\begin{array}{c}\text { Neutral } \\
\mathrm{N}(\%)\end{array}$ & $\begin{array}{c}\text { Somewhat } \\
\text { Unimportant } \\
\mathrm{N}(\%)\end{array}$ & $\begin{array}{c}\text { Unimportant } \\
\mathrm{N}(\%)\end{array}$ & $\begin{array}{c}\text { Response } \\
\text { Count }\end{array}$ \\
\hline Interpersonal & $80.0(48)$ & $18.3(11)$ & $1.7(1)$ & $0.0(0)$ & $0.0(0)$ & 60 \\
\hline Leadership & $71.2(42)$ & $27.1(16)$ & $1.7(1)$ & $0.0(0)$ & $0.0(0)$ & 59 \\
\hline $\begin{array}{l}\text { Personnel } \\
\text { Management }\end{array}$ & $63.3(38)$ & $36.7(22)$ & $0.0(0)$ & $0.0(0)$ & $0.0(0)$ & 60 \\
\hline Communication & $86.7(52)$ & $13.3(8)$ & $0.0(0)$ & $0.0(0)$ & $0.0(0)$ & 60 \\
\hline $\begin{array}{l}\text { Time } \\
\text { Management }\end{array}$ & $80.0(48)$ & $16.7(10)$ & $3.3(2)$ & $0.0(0)$ & $0.0(0)$ & 60 \\
\hline $\begin{array}{l}\text { Mentoring/ } \\
\text { Counseling }\end{array}$ & $71.7(43)$ & $26.7(16)$ & $0.0(0)$ & $1.7(1)$ & $0.0(0)$ & 60 \\
\hline Problem Solving & $73.3(44)$ & $26.7(16)$ & $0.0(0)$ & $0.0(0)$ & $0.0(0)$ & 60 \\
\hline $\begin{array}{l}\text { Conflict } \\
\text { Resolution }\end{array}$ & $75.0(45)$ & $25.0(15)$ & $0.0(0)$ & $0.0(0)$ & $0.0(0)$ & 60 \\
\hline Computer & $35.6(21)$ & $44.1(26)$ & $20.3(12)$ & $0.0(0)$ & $0.0(0)$ & 59 \\
\hline
\end{tabular}

Table 29 reflects that the following skills were rated "Very Important" by at least $80 \%$ of the ACUHO-I respondents: "Communication" (92.9\%), "Interpersonal” (92.9\%), and "Leadership" (82.1\%). 
Table 29

ACUHO-I Resident Directors' Rating of Level of Importance of Skills

\begin{tabular}{lcccccc}
\hline Skills & $\begin{array}{c}\text { Very } \\
\text { Important } \\
\%(\mathrm{~N})\end{array}$ & $\begin{array}{c}\text { Somewhat } \\
\text { Important } \\
\%(\mathrm{~N})\end{array}$ & $\begin{array}{c}\text { Neutral } \\
\%(\mathrm{~N})\end{array}$ & $\begin{array}{c}\text { Somewhat } \\
\text { Unimportant } \\
\%(\mathrm{~N})\end{array}$ & $\begin{array}{c}\text { Unimportant } \\
\%(\mathrm{~N})\end{array}$ & $\begin{array}{c}\text { Response } \\
\text { Count }\end{array}$ \\
\hline Interpersonal & $92.9(26)$ & $7.1(2)$ & $0.0(0)$ & $0.0(0)$ & $0.0(0)$ & 28 \\
Leadership & $82.1(23)$ & $14.3(4)$ & $3.6(1)$ & $0.0(0)$ & $0.0(0)$ & 28 \\
$\begin{array}{l}\text { Personnel } \\
\text { Management }\end{array}$ & $71.4(20)$ & $28.6(8)$ & $0.0(0$ & $0.0(0)$ & $0.0(0)$ & 28 \\
Communication & $92.9(26)$ & $7.1(2)$ & $0.0(0)$ & $0.0(0)$ & $0.0(0)$ & 28 \\
$\begin{array}{l}\text { Time } \\
\text { Management }\end{array}$ & $67.9(19)$ & $28.6(8)$ & $0.0(0)$ & $3.6(1)$ & $0.0(0)$ & 28 \\
$\begin{array}{l}\text { Mentoring/ } \\
\text { Counseling }\end{array}$ & $60.7(17)$ & $32.1(9)$ & $7.1(2)$ & $0.0(0)$ & $0.0(0)$ & 28 \\
Problem & $78.6(22)$ & $21.4(6)$ & $0.0(0)$ & $0.0(0)$ & $0.0(0)$ & 28 \\
Solving & & & & & & \\
Conflict & $67.9(19)$ & $28.6(8)$ & $0.0(0)$ & $3.6(1)$ & $0.0(0)$ & 28 \\
Resolution & & & & & & \\
Computer & $39.3(11)$ & $50.0(14)$ & $7.1(2)$ & $3.6(1)$ & $0.0(0)$ & 28 \\
\hline
\end{tabular}

Administrators were asked to rate the importance of skills needed to be a resident director. Table 30 reflects that the following skills were rated "Very Important" by at least $80 \%$ of the respondents: "Communication" (90.5\%) and "Interpersonal" (85.7\%). 
Table 30

Administrators' Rating of Level of Importance of Skills

\begin{tabular}{|c|c|c|c|c|c|c|}
\hline Skills & $\begin{array}{c}\text { Very } \\
\text { Important } \\
\%(\mathrm{~N})\end{array}$ & $\begin{array}{c}\text { Somewhat } \\
\text { Important } \\
\%(\mathrm{~N})\end{array}$ & $\begin{array}{c}\text { Neutral } \\
\%(\mathrm{~N})\end{array}$ & $\begin{array}{c}\text { Somewhat } \\
\text { Unimportant } \\
\%(\mathrm{~N})\end{array}$ & $\begin{array}{c}\text { Unimportant } \\
\%(\mathrm{~N})\end{array}$ & $\begin{array}{c}\text { Response } \\
\text { Count }\end{array}$ \\
\hline Interpersonal & $85.7(36)$ & $11.9(5)$ & $0.0(0)$ & $2.4(1)$ & $0.0(0)$ & 42 \\
\hline Leadership & $47.6(20)$ & $50.0(21)$ & $0.0(0)$ & $2.4(1)$ & $0.0(0)$ & 42 \\
\hline $\begin{array}{l}\text { Personnel } \\
\text { Management }\end{array}$ & $45.2(19)$ & $52.4(22)$ & $0.0(0)$ & $0.0(0)$ & $2.4(1)$ & 42 \\
\hline Communication & $90.5(38)$ & $7.1(3)$ & $0.0(0)$ & $0.0(0)$ & $2.4(1)$ & 42 \\
\hline $\begin{array}{l}\text { Time } \\
\text { Management }\end{array}$ & $57.1(24)$ & $40.5(17)$ & $0.0(0)$ & $2.4(1)$ & $0.0(0)$ & 42 \\
\hline $\begin{array}{l}\text { Mentoring/ } \\
\text { Counseling }\end{array}$ & $40.5(17)$ & $50.0(21)$ & $4.7(2)$ & $2.4(1)$ & $2.4(1)$ & 42 \\
\hline $\begin{array}{l}\text { Problem } \\
\text { Solving }\end{array}$ & $59.5(25)$ & $35.7(15)$ & $0.0(0)$ & $2.4(1)$ & $0.0(0)$ & 41 \\
\hline $\begin{array}{l}\text { Conflict } \\
\text { Resolution }\end{array}$ & $50.0(21)$ & $47.6(20)$ & $0.0(0)$ & $2.4(1)$ & $0.0(0)$ & 42 \\
\hline Computer & $21.4(9)$ & $59.5(25)$ & $14.3(6)$ & $2.4(1)$ & $0.0(0)$ & 41 \\
\hline
\end{tabular}

\section{Comparison of Education}

Resident directors were asked to indicate their current level of education. Table 31 reflects that the majority held a Masters degree with $75.9 \%(n=66)$ in this category. The HEPC and ACUHO-I survey results were similar in that the majority of respondents held a Masters degree. 
Table 31

Resident Directors' Current Level of Education

\begin{tabular}{|c|c|c|c|c|c|c|}
\hline Education & $\begin{array}{c}\text { RD } \\
\text { HEPC } \\
\mathrm{N}\end{array}$ & $\begin{array}{c}\text { RD } \\
\text { HEPC } \\
\%\end{array}$ & $\begin{array}{c}\text { RD } \\
\text { ACUHOI } \\
\mathrm{N}\end{array}$ & $\begin{array}{c}\text { RD } \\
\text { ACUHOI } \\
\%\end{array}$ & $\begin{array}{c}\text { RD } \\
\text { Total } \\
\mathrm{N}\end{array}$ & $\begin{array}{c}\mathrm{RD} \\
\text { Total } \\
\%\end{array}$ \\
\hline $\begin{array}{l}\text { Some } \\
\text { Undergraduate }\end{array}$ & 3 & 5.1 & 0 & 0.0 & 3 & 3.4 \\
\hline Bachelors & 2 & 3.4 & 1 & 3.6 & 3 & 3.4 \\
\hline Some Graduate & 9 & 15.3 & 6 & 21.4 & 15 & 17.3 \\
\hline Masters & 45 & 76.3 & 21 & 75.0 & 66 & 75.9 \\
\hline Doctorate & 0 & 0.0 & 0 & 0.0 & 0 & 0.0 \\
\hline Total Answered & 59 & & 28 & & 87 & \\
\hline Skipped Question & 8 & & 7 & & 15 & \\
\hline
\end{tabular}

Resident directors were asked to list the level of education they had when they were first hired. Table 32 indicates that the majority held a Masters degree with $52.3 \%(n=46)$ in this category. The HEPC and ACUHO-I survey results were similar in that the majority of respondents held a Masters degree when first hired.

Table 32

Resident Directors' Level of Education When First Hired

\begin{tabular}{lcccccc}
\hline $\begin{array}{l}\text { Level of } \\
\text { Education }\end{array}$ & RD & RD & RD & RD & RD & RD \\
& NEPC & HEPC & ACUHOI & ACUHOI & $\%$ & Total \\
Some & 3 & 5.0 & 0 & 0.0 & 3 & $\begin{array}{c}\text { Total } \\
\%\end{array}$ \\
\hline $\begin{array}{l}\text { Undergraduate } \\
\text { Bachelors }\end{array}$ & 20 & 33.3 & 13 & 46.4 & 33 & 37.5 \\
& & & & & & \\
\end{tabular}




\begin{tabular}{|c|c|c|c|c|c|c|}
\hline $\begin{array}{l}\text { Level of } \\
\text { Education }\end{array}$ & $\begin{array}{c}\text { RD } \\
\text { HEPC } \\
\mathrm{N}\end{array}$ & $\begin{array}{c}\text { RD } \\
\text { HEPC } \\
\% \\
\end{array}$ & $\begin{array}{c}\text { RD } \\
\text { ACUHOI } \\
\mathrm{N}\end{array}$ & $\begin{array}{c}\text { RD } \\
\text { ACUHOI } \\
\%\end{array}$ & $\begin{array}{c}\text { RD } \\
\text { Total } \\
\mathrm{N} \\
\end{array}$ & $\begin{array}{c}\text { RD } \\
\text { Total } \\
\% \\
\end{array}$ \\
\hline Some Graduate & 5 & 8.3 & 1 & 3.6 & 6 & 6.8 \\
\hline Masters & 32 & 53.3 & 14 & 50.0 & 46 & 52.3 \\
\hline Doctorate & 0 & 0.0 & 0 & 0.0 & 0 & 0.0 \\
\hline Total Answered & 60 & & 28 & & 88 & \\
\hline Skipped Question & 7 & & 7 & & 14 & \\
\hline
\end{tabular}

Resident directors were asked about their enrollment in a degree program. Table 33 reflects that the majority were not enrolled in a degree program with $70.5 \%(n=62)$ in this category. The HEPC and ACUHO-I survey results were similar in that the majority of respondents were not enrolled in a degree program.

Table 33

Resident Directors Enrolled in Degree Program

\begin{tabular}{|c|c|c|c|c|c|c|}
\hline Enrolled Status & $\begin{array}{c}\text { RD } \\
\text { HEPC } \\
\mathrm{N}\end{array}$ & $\begin{array}{c}\text { RD } \\
\text { HEPC } \\
\%\end{array}$ & $\begin{array}{c}\mathrm{RD} \\
\text { ACUHOI } \\
\mathrm{N}\end{array}$ & $\begin{array}{c}\text { RD } \\
\text { ACUHOI } \\
\%\end{array}$ & $\begin{array}{c}\mathrm{RD} \\
\text { Total } \\
\mathrm{N}\end{array}$ & $\begin{array}{c}\mathrm{RD} \\
\text { Total } \\
\% \\
\end{array}$ \\
\hline Yes & 18 & 30.0 & 8 & 28.6 & 26 & 29.5 \\
\hline No & 42 & 70.0 & 20 & 71.4 & 62 & 70.5 \\
\hline Total Answered & 60 & & 28 & & 88 & \\
\hline Skipped Question & 7 & & 7 & & 14 & \\
\hline
\end{tabular}

Table 34 indicates that of the 26 resident directors enrolled in a degree program, the majority were enrolled in a Masters degree program with $65.4 \%(n=17)$ in this category. The HEPC and ACUHO-I survey results were similar in that the majority of respondents were 
enrolled in a Masters degree program. It should be noted that none of the ACUHO-I resident directors were enrolled in a Bachelors program while $16.7 \%$ of HEPC resident directors were. Table 34

Degree Programs Resident Directors Currently Enrolled In

\begin{tabular}{|c|c|c|c|c|c|c|}
\hline Degree & $\begin{array}{c}\text { RD } \\
\text { HEPC } \\
\mathrm{N}\end{array}$ & $\begin{array}{c}\text { RD } \\
\text { HEPC } \\
\% \\
\end{array}$ & $\begin{array}{c}\text { RD } \\
\text { ACUHOI } \\
\mathrm{N} \\
\end{array}$ & $\begin{array}{c}\text { RD } \\
\text { ACUHOI } \\
\% \\
\end{array}$ & $\begin{array}{c}\mathrm{RD} \\
\text { Total } \\
\mathrm{N} \\
\end{array}$ & $\begin{array}{c}\text { RD } \\
\text { Total } \\
\% \\
\end{array}$ \\
\hline Bachelors & 3 & 16.7 & 0 & 0.0 & 3 & 11.5 \\
\hline Masters & 10 & 55.6 & 7 & 87.5 & 17 & 65.4 \\
\hline Doctorate & 5 & 27.8 & 1 & 12.5 & 6 & 23.1 \\
\hline Total Answered & 18 & & 8 & & 26 & \\
\hline Skipped Question & 49 & & 27 & & 76 & \\
\hline
\end{tabular}

Resident directors were asked about their plans to enroll in a degree program in the near future. Table 35 reflects that the majority of the resident directors plan to enroll in a degree program in the near future with $53.2 \%(n=33)$ in this category. The majority of HEPC resident directors planned to enroll in a degree program while the majority of ACUHO-I resident directors did not plan to enroll in a degree program.

Table 35

Resident Directors' Plan to Enroll in Degree Program in Near Future

\begin{tabular}{|c|c|c|c|c|c|c|}
\hline Enrollment Plans & $\begin{array}{c}\text { RD } \\
\text { HEPC } \\
\mathrm{N}\end{array}$ & $\begin{array}{c}\text { RD } \\
\text { HEPC } \\
\% \\
\end{array}$ & $\begin{array}{c}\text { RD } \\
\text { ACUHOI } \\
\mathrm{N}\end{array}$ & $\begin{array}{c}\text { RD } \\
\text { ACUHOI } \\
\%\end{array}$ & $\begin{array}{c}\mathrm{RD} \\
\text { Total } \\
\mathrm{N}\end{array}$ & $\begin{array}{c}\text { RD } \\
\text { Total } \\
\%\end{array}$ \\
\hline Yes & 24 & 57.1 & 9 & 45.0 & 33 & 53.2 \\
\hline No & 18 & 42.9 & 11 & 55.0 & 29 & 46.8 \\
\hline
\end{tabular}




\begin{tabular}{lcccccc}
\hline Enrollment Plans & RD & RD & RD & RD & RD & RD \\
& HEPC & HEPC & ACUHOI & ACUHOI & Total & $\begin{array}{c}\text { Total } \\
\%\end{array}$ \\
& N & $\%$ & N & $\%$ & N & $\%$ \\
\hline Total Answered & 42 & & 20 & & 62 & \\
Skipped & 25 & & 16 & & 41 & \\
Question & & & & & & \\
& & & & & & \\
\hline
\end{tabular}

Table 36 reflects that of the 33 resident directors that plan to enroll in a degree program, the majority plan to enroll in a Doctorate degree program with $93.9 \%(n=31)$ in this category. The HEPC and ACUHO-I survey results were similar in that the majority of respondents plan to enroll in a Doctorate degree program.

Table 36

Degree Programs Resident Directors Plan to Enroll in Near Future

\begin{tabular}{lcccccc}
\hline Degree & RD & RD & RD & RD & RD & RD \\
& HEPC & HEPC & ACUHOI & ACUHOI & Total & Total \\
& N & $\%$ & N & $\%$ & N & $\%$ \\
\hline Bachelors & 0 & 0.0 & 0 & 0.0 & 0 & 0.0 \\
Masters & 2 & 6.3 & 0 & 0.0 & 2 & 6.1 \\
Doctorate & 22 & 91.7 & 9 & 100.0 & 31 & 93.9 \\
Total Answered & 24 & & 9 & & 33 & \\
\hline
\end{tabular}

Administrators were asked to list the minimum level of education required to be a resident director at their institution. Table 37 reflects that the majority indicated that resident directors need a Masters degree with $64.3 \%(\mathrm{n}=27)$ rating this category. The HEPC and ACUHO-I survey results were similar in that the majority indicated that the job requirement for resident directors had a minimum of a Masters degree. 
Table 37

Minimum Level of Education Required for Resident Directors

\begin{tabular}{lcccccc}
\hline Education & $\begin{array}{c}\text { Admin. } \\
\text { HEPC } \\
\text { N }\end{array}$ & $\begin{array}{c}\text { Admin. } \\
\text { HEPC }\end{array}$ & $\begin{array}{c}\text { Admin. } \\
\text { ACUHOI }\end{array}$ & $\begin{array}{c}\text { Admin. } \\
\text { ACUHOI } \\
\%\end{array}$ & $\begin{array}{c}\text { Admin. } \\
\text { Total } \\
\text { N }\end{array}$ & $\begin{array}{c}\text { Admin. } \\
\text { Total } \\
\%\end{array}$ \\
\hline $\begin{array}{l}\text { Some } \\
\text { Undergraduate }\end{array}$ & 1 & 4.3 & 0 & 0.0 & 1 & 2.4 \\
Bachelors & 7 & 30.4 & 7 & 36.8 & 14 & 33.3 \\
Some Graduate & 0 & 0.0 & 0 & 0.0 & 0 & 0.0 \\
Masters & 15 & 65.2 & 12 & 63.2 & 27 & 64.3 \\
Doctorate & 0 & 0.0 & 0 & 0.0 & 0 & 0.0 \\
Total Answered & 23 & & 19 & & 42 & \\
Skipped Question & 3 & & 1 & & & \\
\end{tabular}

Administrators were asked to rate how often they were able to hire resident directors who met the minimum educational requirements of the position. Table 38 reflects that the majority were "Always" able to hire candidates with the minimum educational requirements with $78.6 \%$ $(n=33)$ rating this category. The HEPC and ACUHO-I survey results were similar in that the majority of respondents were "Always" able to hire candidates who met the minimum educational requirements. However, it should be noted that ACUHO-I administrators rated "Often" and "Rarely" at $0 \%$ while HEPC administrators rated these categories at a combined response rate of $13 \%$. 
Table 38

Administrators' Ability to Hire Candidates Who Meet Minimum Educational Requirements

\begin{tabular}{|c|c|c|c|c|c|c|}
\hline Hiring Ability & $\begin{array}{c}\text { HEPC } \\
\mathrm{N}\end{array}$ & $\begin{array}{c}\text { HEPC } \\
\%\end{array}$ & $\begin{array}{c}\text { ACUHOI } \\
\mathrm{N}\end{array}$ & $\begin{array}{c}\text { ACUHOI } \\
\%\end{array}$ & $\begin{array}{c}\text { Total } \\
\mathrm{N}\end{array}$ & $\begin{array}{c}\text { Total } \\
\%\end{array}$ \\
\hline Always & 17 & 73.9 & 16 & 84.2 & 33 & 78.6 \\
\hline Very Often & 3 & 13.0 & 3 & 15.8 & 6 & 14.3 \\
\hline Often & 2 & 8.7 & 0 & 0.0 & 2 & 4.7 \\
\hline Sometimes & 0 & 0.0 & 0 & 0.0 & 0 & 0.0 \\
\hline Rarely & 1 & 4.3 & 0 & 0.0 & 1 & 2.4 \\
\hline Total Answered & 23 & & 19 & & 42 & \\
\hline Skipped Question & 3 & & 1 & & 4 & \\
\hline
\end{tabular}

\section{Comparison of Experience}

Administrators were asked to list whether resident assistant experience was a requirement of the resident director position at their institution. Table 39 reflects that the majority of respondents indicated that resident assistant experience was not required with $95.2 \%(n=40)$ rating this category. The HEPC and ACUHO-I survey results were similar in that the majority of respondents did not require resident assistant experience.

Table 39

Resident Assistant Experience Required

\begin{tabular}{|c|c|c|c|c|c|c|}
\hline RA Experience & $\begin{array}{l}\text { Admin. } \\
\text { HEPC } \\
\mathrm{N}\end{array}$ & $\begin{array}{c}\text { Admin. } \\
\text { HEPC } \\
\%\end{array}$ & $\begin{array}{l}\text { Admin. } \\
\text { ACUHOI } \\
\mathrm{N}\end{array}$ & $\begin{array}{c}\text { Admin. } \\
\text { ACUHOI } \\
\%\end{array}$ & $\begin{array}{l}\text { Admin. } \\
\text { Total } \\
\text { N }\end{array}$ & $\begin{array}{c}\text { Admin } \\
\text { Total } \\
\%\end{array}$ \\
\hline Yes & 2 & 8.7 & 0 & 0.0 & 2 & 4.8 \\
\hline
\end{tabular}




\begin{tabular}{lcccccc}
\hline RA Experience & Admin. & Admin. & Admin. & Admin. & Admin. & Admin \\
& HEPC & HEPC & ACUHOI & ACUHOI & Total & Total \\
& N & $\%$ & N & $\%$ & N & $\%$ \\
\hline No & 21 & 91.3 & 19 & 100.0 & 40 & 95.2 \\
Total Answered & 23 & & 19 & & 42 & \\
Skipped Question & 3 & & 1 & & 4 & \\
\hline
\end{tabular}

Table 40 reflects that of the two HEPC institutions that required resident assistant experience, one respondent indicated that they required "1 Year or Less."

Table 40

Years of Resident Assistant Experience Required

\begin{tabular}{lcccccc}
\hline Years Experience & $\begin{array}{c}\text { Admin. } \\
\text { HEPC }\end{array}$ & $\begin{array}{c}\text { Admin. } \\
\text { HEPC }\end{array}$ & $\begin{array}{c}\text { Admin. } \\
\text { ACUHOI }\end{array}$ & $\begin{array}{c}\text { Admin. } \\
\text { ACUHOI } \\
\%\end{array}$ & $\begin{array}{c}\text { Admin. } \\
\text { Total } \\
\text { N }\end{array}$ & $\begin{array}{c}\text { Admin. } \\
\text { Total } \\
\%\end{array}$ \\
\hline 1 Year or Less & 1 & 100.0 & 0 & 0.0 & 1 & 100.0 \\
2 Years & 0 & 0.0 & 0 & 0.0 & 0 & 0.0 \\
3 Years & 0 & 0.0 & 0 & 0.0 & 0 & 0.0 \\
4 Years & 0 & 0.0 & 0 & 0.0 & 0 & 0.0 \\
5 or More Years & 0 & 0.0 & 0 & 0.0 & 0 & 0.0 \\
Total Answered & 1 & & 0 & & 1 & \\
Skipped Question & 25 & & 20 & & 45 & \\
\hline
\end{tabular}

Resident directors were asked to list if they had resident assistant experience. Table 41 reflects that the majority had resident assistant experience with $75.0 \%(\mathrm{n}=66)$ in this category. 
The HEPC and ACUHO-I survey results were similar in that the majority of respondents had resident director experience.

Table 41

Resident Assistant Experience of Resident Directors

\begin{tabular}{|c|c|c|c|c|c|c|}
\hline RA Experience & $\begin{array}{c}\text { RD } \\
\text { HEPC } \\
N\end{array}$ & $\begin{array}{c}\text { RD } \\
\text { HEPC } \\
\%\end{array}$ & $\begin{array}{c}\mathrm{RD} \\
\text { ACUHOI } \\
\mathrm{N}\end{array}$ & $\begin{array}{c}\text { RD } \\
\text { ACUHOI } \\
\%\end{array}$ & $\begin{array}{c}\mathrm{RD} \\
\text { Total } \\
\mathrm{N}\end{array}$ & $\begin{array}{c}\mathrm{RD} \\
\text { Total } \\
\%\end{array}$ \\
\hline Yes & 43 & 71.7 & 23 & 82.1 & 66 & 75.0 \\
\hline No & 17 & 28.3 & 5 & 17.9 & 22 & 25.0 \\
\hline Total Answered & 60 & & 28 & & 88 & \\
\hline Skipped & 7 & & 7 & & 14 & \\
\hline Question & & & & & & \\
\hline
\end{tabular}

Table 42 reflects that of the 66 resident directors who had resident assistant experience, the majority had "2 Years" experience with 53\% $(n=35)$ in this category. The HEPC and ACUHO-I survey results were similar in that the majority of respondents had " 2 Years Experience."

Table 42

Years of Resident Assistant Experience held by Resident Directors

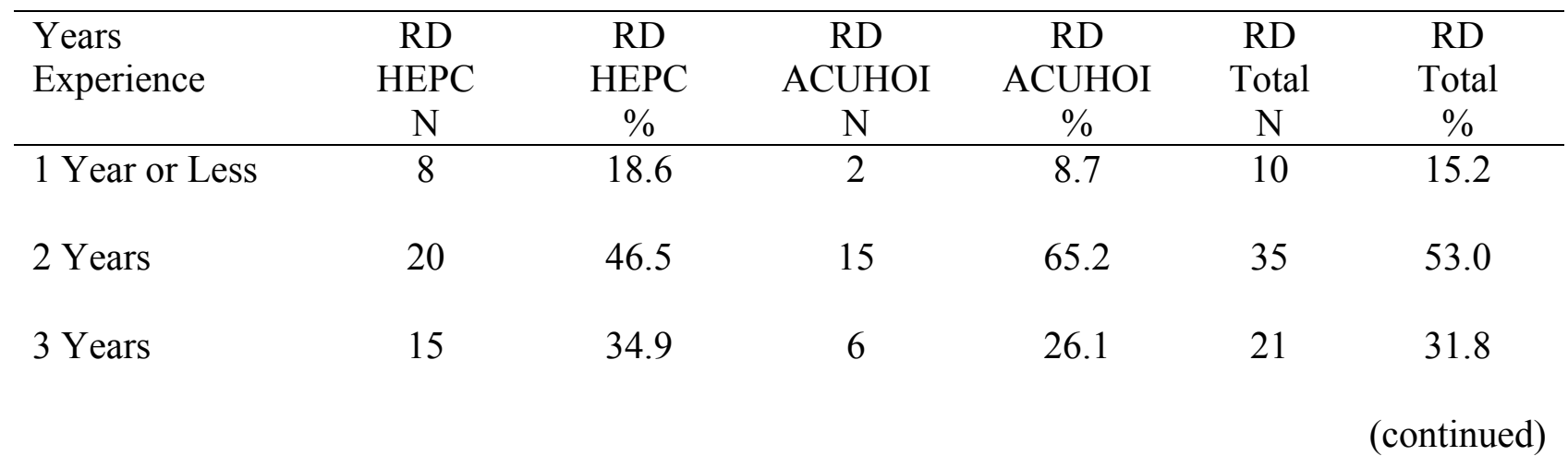




\begin{tabular}{|c|c|c|c|c|c|c|}
\hline $\begin{array}{l}\text { Years } \\
\text { Experience }\end{array}$ & $\begin{array}{c}\text { RD } \\
\text { HEPC } \\
\mathrm{N}\end{array}$ & $\begin{array}{c}\text { RD } \\
\text { HEPC } \\
\%\end{array}$ & $\begin{array}{c}\text { RD } \\
\text { ACUHOI } \\
\mathrm{N}\end{array}$ & $\begin{array}{c}\text { RD } \\
\text { ACUHOI } \\
\%\end{array}$ & $\begin{array}{c}\mathrm{RD} \\
\text { Total } \\
\mathrm{N}\end{array}$ & $\begin{array}{c}\text { RD } \\
\text { Total } \\
\%\end{array}$ \\
\hline 4 Years & 0 & 0.0 & 0 & 0.0 & 0 & 0.0 \\
\hline 5 or More Years & 0 & 0.0 & 0 & 0.0 & 0 & 0.0 \\
\hline Total Answered & 43 & & 23 & & 66 & \\
\hline Skipped & 24 & & 12 & & 36 & \\
\hline Question & & & & & & \\
\hline
\end{tabular}

Administrators were asked if student affairs experience was a requirement of the resident director position at their institution. Table 43 reflects that the majority indicated that student affairs experience was not a requirement with $61 \%(\mathrm{n}=25)$ in this category. The HEPC and ACUHO-I survey results were similar in that the majority of respondents did not require student affairs experience.

Table 43

Student Affairs Experience Required

\begin{tabular}{lcccccc}
\hline Student Affairs & $\begin{array}{c}\text { Admin. } \\
\text { Experience }\end{array}$ & $\begin{array}{c}\text { Admin. } \\
\text { HEPC }\end{array}$ & $\begin{array}{c}\text { Admin. } \\
\text { HEPC }\end{array}$ & $\begin{array}{c}\text { Admin. } \\
\text { ACUOI }\end{array}$ & $\begin{array}{c}\text { Admin. } \\
\text { ACUHOI }\end{array}$ & $\begin{array}{c}\text { Admin } \\
\text { Total } \\
\text { Total } \\
\%\end{array}$ \\
\hline Yes & 9 & 40.9 & 7 & 36.8 & 16 & 39.0 \\
No & 13 & 59.1 & 12 & 63.2 & 25 & 61.0 \\
Total Answered & 22 & & 19 & & 41 & \\
Skipped Question & 4 & & 1 & & 5 & \\
\hline
\end{tabular}


Table 44 reflects that of the 16 institutions that required student affairs experience for the resident director position, the majority required " 1 Year or Less" with $56.2 \%(n=9)$ in this category. The HEPC and ACUHO-I survey results were similar in that the majority of respondents that required student affairs experience required only "1 Year or Less."

Table 44

Years of Student Affairs Experience Required

\begin{tabular}{lcccccc}
\hline Years Experience & $\begin{array}{c}\text { Admin. } \\
\text { HEPC } \\
\text { N }\end{array}$ & $\begin{array}{c}\text { Admin. } \\
\text { HEPC } \\
\%\end{array}$ & $\begin{array}{c}\text { Admin. } \\
\text { ACUHOI } \\
\text { N }\end{array}$ & $\begin{array}{c}\text { Admin. } \\
\text { ACUHOI } \\
\%\end{array}$ & $\begin{array}{c}\text { Admin. } \\
\text { Total } \\
\text { N }\end{array}$ & $\begin{array}{c}\text { Admin. } \\
\text { Total } \\
\%\end{array}$ \\
\hline 1 Year or Less & 5 & 55.6 & 4 & 57.1 & 9 & 56.2 \\
2 Years & 4 & 44.4 & 3 & 42.9 & 7 & 43.8 \\
3 Years & 0 & 0.0 & 0 & 0.0 & 0 & 0.0 \\
4 Years & 0 & 0.0 & 0 & 0.0 & 0 & 0.0 \\
5 or More Years & 0 & 0.0 & 0 & 0.0 & 0 & 0.0 \\
Total Answered & 9 & & 7 & & 16 & \\
Skipped Question & 17 & & 13 & & 30 & \\
\hline
\end{tabular}

Resident directors were asked if they had student affairs experience. Table 45 reflects that the majority indicated that they had student affairs experience with $65.9 \%(\mathrm{n}=58)$ in this category. The HEPC and ACUHO-I survey results were similar in that the majority of respondents had student affairs experience. 
Table 45

Resident Directors' Student Affairs Experience

\begin{tabular}{|c|c|c|c|c|c|c|}
\hline $\begin{array}{l}\text { Student Affairs } \\
\text { Experience }\end{array}$ & $\begin{array}{c}\mathrm{RD} \\
\mathrm{HEPC} \\
\mathrm{N} \\
\end{array}$ & $\begin{array}{c}\text { RD } \\
\text { HEPC } \\
\% \\
\end{array}$ & $\begin{array}{c}\text { RD } \\
\text { ACUHOI } \\
\mathrm{N}\end{array}$ & $\begin{array}{c}\text { RD } \\
\text { ACUHOI } \\
\% \\
\end{array}$ & $\begin{array}{c}\mathrm{RD} \\
\text { Total } \\
\mathrm{N}\end{array}$ & $\begin{array}{c}\text { RD } \\
\text { Total } \\
\% \\
\end{array}$ \\
\hline Yes & 41 & 68.3 & 17 & 60.7 & 58 & 65.9 \\
\hline No & 19 & 31.7 & 11 & 39.3 & 30 & 34.1 \\
\hline Total Answered & 60 & & 28 & & 88 & \\
\hline Skipped Question & 7 & & 7 & & 14 & \\
\hline
\end{tabular}

Table 46 reflects that of the 58 respondents who had student affairs experience, the majority had "2 Years" with 29.3\% $(n=17)$ in this category. The HEPC and ACUHO-I survey results were similar in that the majority of respondents had "2 Years" student affairs experience.

Table 46

Years of Student Affairs Experience held by Resident Directors

\begin{tabular}{|c|c|c|c|c|c|c|}
\hline $\begin{array}{l}\text { Years } \\
\text { Experience }\end{array}$ & $\begin{array}{c}\text { RD } \\
\text { HEPC } \\
\mathrm{N}\end{array}$ & $\begin{array}{c}\text { RD } \\
\text { HEPC } \\
\% \\
\end{array}$ & $\begin{array}{c}\text { RD } \\
\text { ACUHOI } \\
\mathrm{N}\end{array}$ & $\begin{array}{c}\text { RD } \\
\text { ACUHOI } \\
\% \\
\end{array}$ & $\begin{array}{c}\mathrm{RD} \\
\text { Total } \\
\mathrm{N}\end{array}$ & $\begin{array}{c}\mathrm{RD} \\
\text { Total } \\
\% \\
\end{array}$ \\
\hline 1 Year or Less & 11 & 26.8 & 4 & 23.5 & 15 & 25.9 \\
\hline 2 Years & 12 & 29.3 & 5 & 29.4 & 17 & 29.3 \\
\hline 3 Years & 6 & 14.6 & 4 & 23.5 & 10 & 17.2 \\
\hline 4 Years & 4 & 9.8 & 2 & 11.8 & 6 & 10.4 \\
\hline 5 or More Years & 8 & 19.5 & 2 & 11.8 & 10 & 17.2 \\
\hline Total Answered & 41 & & 17 & & 58 & \\
\hline Skipped Question & 26 & & 18 & & 44 & \\
\hline
\end{tabular}


Administrators were asked to rate how often they were able to hire high quality resident directors. Table 47 reflects that the majority indicated they were "Always" able to hire high quality resident directors with $61 \%(n=25)$ rating this category. The HEPC and ACUHO-I survey results were similar in that the majority of respondents were "Always" able to hire high quality resident directors. However, it should be noted that ACUHO-I administrators rated "Always" 23.7\% higher than their HEPC peers.

Table 47

Administrators' Ability to Hire High Quality Resident Directors

\begin{tabular}{lcccccc}
\hline Hiring Ability & $\begin{array}{c}\text { Admin. } \\
\text { HEPC } \\
\text { N }\end{array}$ & $\begin{array}{c}\text { Admin. } \\
\text { HEPC } \\
\%\end{array}$ & $\begin{array}{c}\text { Admin. } \\
\text { ACUHOI }\end{array}$ & $\begin{array}{c}\text { Admin. } \\
\text { ACUHOI } \\
\%\end{array}$ & $\begin{array}{c}\text { Admin. } \\
\text { Total } \\
\text { N }\end{array}$ & $\begin{array}{c}\text { Admin } \\
\text { Total } \\
\%\end{array}$ \\
\hline Always & 11 & 50.0 & 14 & 73.7 & 25 & 61.0 \\
Very Often & 9 & 40.9 & 5 & 26.3 & 14 & 34.1 \\
Often & 2 & 9.1 & 0 & 0.0 & 2 & 4.9 \\
Sometimes & 0 & 0.0 & 0 & 0.0 & 0 & 0.0 \\
Rarely & 0 & 0.0 & 0 & 0.0 & 0 & 0.0 \\
Total Answered & 22 & & 19 & & 41 & \\
Skipped Question & 4 & & & & & \\
\end{tabular}

Administrators were asked to list the advertisement and recruitment methods utilized to recruit resident directors. Table 48 reflects that $97.6 \%(n=40)$ utilized "Institutional Postings," 92.7\% (n=38) utilized "Professional Organization Postings," 85.3\% (n=35) utilized "National Advertisements," and 70.7\% (n=29) utilized "Recruitment Fairs." Five respondents list other methods such as referrals from other Chief Housing Officers, partnerships with other institutions, magazine ads, emails and specified websites such as StudentAffairs.com. The HEPC and 
ACUHO-I survey results were similar in that the majority of respondents utilized "Institutional Postings" and "Professional Organization Postings."

Table 48

Advertisement and Recruitment Methods Utilized by Administrators

\begin{tabular}{|c|c|c|c|c|c|c|}
\hline Method & $\begin{array}{c}\text { Admin. } \\
\text { HEPC } \\
\mathrm{N}\end{array}$ & $\begin{array}{c}\text { Admin. } \\
\text { HEPC } \\
\%\end{array}$ & $\begin{array}{c}\text { Admin. } \\
\text { ACUHOI } \\
\mathrm{N} \\
\end{array}$ & $\begin{array}{c}\text { Admin. } \\
\text { ACUHOI } \\
\% \\
\end{array}$ & $\begin{array}{c}\text { Admin. } \\
\text { Total } \\
\mathrm{N}\end{array}$ & $\begin{array}{c}\text { Admin } \\
\text { Total } \\
\% \\
\end{array}$ \\
\hline Institutional Posting & 21 & 95.4 & 19 & 100.0 & 40 & 97.6 \\
\hline Recruitment Fairs & 13 & 59.1 & 16 & 84.2 & 29 & 70.7 \\
\hline $\begin{array}{l}\text { National } \\
\text { Advertisements }\end{array}$ & 19 & 86.4 & 16 & 84.2 & 35 & 85.3 \\
\hline $\begin{array}{l}\text { Professional } \\
\text { Organization } \\
\text { Postings }\end{array}$ & 20 & 90.9 & 18 & 94.7 & 38 & 92.7 \\
\hline Other & 3 & 13.6 & 2 & 10.5 & 5 & 12.2 \\
\hline Total Answered & 22 & & 19 & & 41 & \\
\hline Skipped Question & 4 & & 1 & & 5 & \\
\hline
\end{tabular}

\section{Comparison of Training}

Resident directors were asked to list the number of days they had assumed their duties prior to the academic year. Table 49 reflects that the majority indicated that they had assumed duties "30 Days" prior to the academic year with $50 \%(n=44)$ in this category. The majority of HEPC resident directors assumed duties "30 Days" prior to the academic year while the majority of ACUHO-I resident directors assumed their duties "60 Days" prior to the academic year. 
Table 49

Number of Days Resident Directors Assumed Duties Prior to Academic Year

\begin{tabular}{|c|c|c|c|c|c|c|}
\hline Days & $\begin{array}{c}\text { RD } \\
\text { HEPC } \\
\mathrm{N}\end{array}$ & $\begin{array}{c}\text { RD } \\
\text { HEPC } \\
\% \\
\end{array}$ & $\begin{array}{c}\text { RD } \\
\text { ACUHOI } \\
\mathrm{N}\end{array}$ & $\begin{array}{c}\text { RD } \\
\text { ACUHOI } \\
\% \\
\end{array}$ & $\begin{array}{c}\text { RD } \\
\text { Total } \\
\mathrm{N}\end{array}$ & $\begin{array}{c}\text { RD } \\
\text { Total } \\
\%\end{array}$ \\
\hline 60 Days & 18 & 30.0 & 14 & 50.0 & 32 & 36.4 \\
\hline 30 Days & 33 & 55.0 & 11 & 39.3 & 44 & 50.0 \\
\hline 15 Days & 3 & 5.0 & 1 & 3.6 & 4 & 4.5 \\
\hline Less than 15 Days & 3 & 5.0 & 0 & 0.0 & 3 & 3.4 \\
\hline After the Year Began & 3 & 5.0 & 2 & 7.1 & 5 & 5.7 \\
\hline Total Answered & 60 & & 28 & & 88 & \\
\hline Skipped Question & 7 & & 7 & & 14 & \\
\hline
\end{tabular}

Administrators were asked to list the number of days resident directors typically assumed duties prior to the academic year. Table 50 reflects that the majority assumed duties "30 Days" or "60 Days" prior to the academic year with $46.3 \%(n=19)$ in both of these categories. The majority of HEPC resident directors typically assumed duties "30 Days" prior to the academic year while the majority of ACUHO-I resident directors typically assumed their duties "60 Days" prior to the academic year.

Table 50

Number of Days Resident Directors Typically Assumed Duties Prior to Academic Year

\begin{tabular}{lcccccc}
\hline Days & Admin. & Admin. & Admin. & Admin. & Admin. & Admin. \\
& HEPC & HEPC & ACUHOI & ACUHOI & Total & $\begin{array}{c}\text { Total } \\
\%\end{array}$ \\
\hline 60 Days & 9 & 40.9 & 10 & 52.6 & 19 & 46.3 \\
& & & & & & (continued)
\end{tabular}




\begin{tabular}{|c|c|c|c|c|c|c|}
\hline Days & $\begin{array}{c}\text { Admin. } \\
\text { HEPC } \\
\text { N }\end{array}$ & $\begin{array}{c}\text { Admin. } \\
\text { HEPC } \\
\%\end{array}$ & $\begin{array}{c}\text { Admin. } \\
\text { ACUHOI } \\
\mathrm{N}\end{array}$ & $\begin{array}{c}\text { Admin. } \\
\text { ACUHOI } \\
\%\end{array}$ & $\begin{array}{c}\text { Admin. } \\
\text { Total } \\
\text { N }\end{array}$ & $\begin{array}{c}\text { Admin. } \\
\text { Total } \\
\% \\
\end{array}$ \\
\hline 30 Days & 11 & 50.0 & 8 & 42.1 & 19 & 46.3 \\
\hline 15 Days & 1 & 4.5 & 1 & 5.3 & 2 & 4.9 \\
\hline Less than 15 Days & 1 & 4.5 & 0 & 0.0 & 1 & 2.5 \\
\hline Total Answered & 22 & & 19 & & 41 & \\
\hline Skipped Question & 4 & & 1 & & 5 & \\
\hline
\end{tabular}

Resident director were asked to indicate whether or not they participated in training before the residence halls opened their first year as a resident director. Table 51 reflects that the majority indicated that they had participated in training before the halls opened with $92 \%(\mathrm{n}=80)$ in this category. The HEPC and ACUHO-I survey results were similar in that the majority of first year resident directors participated in training before the residence halls opened.

Table 51

$I^{\text {st }}$ Year Resident Directors that Participated in Training Before Residence Halls Opened

\begin{tabular}{lcccccc}
\hline Participated & RD & RD & RD & RD & RD & RD \\
& HEPC & HEPC & ACUHOI & ACUHOI \\
$\%$ & N & Total & Total \\
Yes & 55 & 93.2 & 25 & 89.3 & 80 & 92.0 \\
No & 4 & 6.8 & 3 & 10.7 & 7 & 8.0 \\
Total Answered & 59 & & 28 & & 87 & \\
Skipped Question & 8 & & 7 & & 15 & \\
\hline
\end{tabular}

Administrators were asked to indicate whether or not they provided training to first year resident directors before the residence halls opened. Table 52 reflects that the majority indicated 
that they provided training before the residence halls opened for first year resident directors with 97.6\% $(n=40)$ in this category. The HEPC and ACUHO-I survey results were similar in that the majority of administrators provided first year resident directors with training before the residence halls opened.

Table 52

Administrators who Provided $1^{\text {st }}$ Year RD Training Before Residence Halls Opened

\begin{tabular}{|c|c|c|c|c|c|c|}
\hline Training Provided & $\begin{array}{c}\text { Admin. } \\
\text { HEPC } \\
\mathrm{N}\end{array}$ & $\begin{array}{c}\text { Admin. } \\
\text { HEPC } \\
\%\end{array}$ & $\begin{array}{c}\text { Admin. } \\
\text { ACUHOI } \\
\mathrm{N} \\
\end{array}$ & $\begin{array}{c}\text { Admin. } \\
\text { ACUHOI } \\
\%\end{array}$ & $\begin{array}{c}\text { Admin. } \\
\text { Total } \\
\mathrm{N}\end{array}$ & $\begin{array}{c}\text { Admin. } \\
\text { Total } \\
\%\end{array}$ \\
\hline Yes & 22 & 100.0 & 18 & 94.7 & 40 & 97.6 \\
\hline No & 0 & 0.0 & 1 & 5.3 & 1 & 2.4 \\
\hline Total Answered & 22 & & 19 & & 41 & \\
\hline Skipped Question & 4 & & 1 & & 5 & \\
\hline
\end{tabular}

Resident directors were asked to indicate the number of days training lasted during their first year as a resident director. Table 53 reflects that the majority indicated that initial training lasted "More than 1 Week" with $87.7 \%(n=71)$ in this category. The HEPC and ACUHO-I survey results were similar in that the majority of resident directors participated in training that lasted "More than 1 Week" during their first year.

Table 53

Length of $1^{\text {st }}$ Year Resident Director Training Before Halls Opened

\begin{tabular}{lcccccc}
\hline Length & RD & RD & RD & RD & RD & RD \\
& HEPC & HEPC & ACUHOI & ACUHOI & Total & Total \\
& $\mathrm{N}$ & $\%$ & N & $\%$ & N & $\%$ \\
\hline 1 Day or Less & 0 & 0.0 & 0 & 0.0 & 0 & 0.0
\end{tabular}

(continued) 


\begin{tabular}{|c|c|c|c|c|c|c|}
\hline Length & $\begin{array}{c}\text { RD } \\
\text { HEPC } \\
N\end{array}$ & $\begin{array}{c}\text { RD } \\
\text { HEPC } \\
\% \\
\end{array}$ & $\begin{array}{c}\text { RD } \\
\text { ACUHOI } \\
\mathrm{N}\end{array}$ & $\begin{array}{c}\text { RD } \\
\text { ACUHOI } \\
\% \\
\end{array}$ & $\begin{array}{c}\text { RD } \\
\text { Total } \\
\mathrm{N} \\
\end{array}$ & $\begin{array}{c}\text { RD } \\
\text { Total } \\
\% \\
\end{array}$ \\
\hline 2-3 Days & 2 & 3.6 & 0 & 0.0 & 2 & 2.5 \\
\hline 4-6 Days & 1 & 1.8 & 0 & 0.0 & 1 & 1.2 \\
\hline 1 Week & 6 & 10.7 & 1 & 4.0 & 7 & 8.6 \\
\hline More than 1 Week & 47 & 83.9 & 24 & 96.0 & 71 & 87.7 \\
\hline Total Answered & 56 & & 25 & & 81 & \\
\hline Skipped Question & 11 & & 10 & & 21 & \\
\hline
\end{tabular}

Administrators were asked to indicate the number of days training lasted for first year resident director before the halls opened. Table 54 reflects that the majority indicated that the training lasted "More than 1 Week" with $82.5 \%(\mathrm{n}=33)$ in this category. The HEPC and ACUHO-I survey results were similar in that the majority of administrators provided training that lasted "More than 1 Week" for first year resident directors.

Table 54

Length of $1^{\text {st }}$ Year Resident Director Training Before Halls Opened Reported by Administrators

\begin{tabular}{lcccccc}
\hline Length & $\begin{array}{c}\text { Admin. } \\
\text { HEPC } \\
\text { N }\end{array}$ & $\begin{array}{c}\text { Admin. } \\
\text { HEPC } \\
\%\end{array}$ & $\begin{array}{c}\text { Admin. } \\
\text { ACUHOI } \\
\text { N }\end{array}$ & $\begin{array}{c}\text { Admin. } \\
\text { ACUHOI } \\
\%\end{array}$ & $\begin{array}{c}\text { Admin. } \\
\text { Total } \\
\mathrm{N}\end{array}$ & $\begin{array}{c}\text { Admin } \\
\text { Total } \\
\%\end{array}$ \\
\hline 1 Day or Less & 0 & 0.0 & 0 & 0.0 & 0 & 0.0 \\
2-3 Days & 1 & 4.5 & 1 & 5.6 & 2 & 5.0 \\
4-6 Days & 0 & 0.0 & 0 & 0.0 & 0 & 0.0 \\
1 Week & 2 & 9.1 & 3 & 16.7 & 5 & 12.5 \\
More than 1 Week & 19 & 86.4 & 14 & 77.8 & 33 & 82.5 \\
& & & & & & \\
\end{tabular}




\begin{tabular}{|c|c|c|c|c|c|c|}
\hline Length & $\begin{array}{c}\text { Admin. } \\
\text { HEPC } \\
\text { N }\end{array}$ & $\begin{array}{c}\text { Admin. } \\
\text { HEPC } \\
\%\end{array}$ & $\begin{array}{l}\text { Admin. } \\
\text { ACUHOI } \\
\mathrm{N}\end{array}$ & $\begin{array}{c}\text { Admin. } \\
\text { ACUHOI } \\
\%\end{array}$ & $\begin{array}{c}\text { Admin. } \\
\text { Total } \\
\text { N }\end{array}$ & $\begin{array}{c}\text { Admin } \\
\text { Total } \\
\%\end{array}$ \\
\hline Total Answered & 22 & & 18 & & 40 & \\
\hline Skipped Question & 4 & & 2 & & 6 & \\
\hline
\end{tabular}

Resident directors were asked to list the topics covered during their first year of training as a resident director. Table 55 reflects that $95.1 \%(\mathrm{n}=77)$ were trained in "Supervision" and "Crisis Management", 93.8\% ( $\mathrm{n}=76)$ were trained in "Student Conduct", 90.1\% $(\mathrm{n}=73)$ were trained in "Daily Hall Operations" and "Programming." The HEPC and ACUHO-I survey results were similar in that at least $90 \%$ of resident directors indicated that they were trained in "Supervision", "Crisis Management", and "Student Conduct". ACUHO-I resident directors included "Daily Hall Operations" as a training topic with over 90\% of the respondents. Eleven resident directors listed other topics with main themes that included "Diversity/Sensitivity Training”, "Time Management", "Working with Faculty", "Working with Student Groups", and "Advising."

Table 55

Topics Covered in $1^{\text {st }}$ Year Training Before Halls Opened

\begin{tabular}{lcccccc}
\hline Training Topics & RD & RD & RD & RD & RD & RD \\
& HEPC & HEPC & ACUHOI & ACUHOI & Total & $\begin{array}{c}\text { Total } \\
\%\end{array}$ \\
\hline Daily Hall Operations & 50 & 89.3 & 23 & 92.0 & 73 & 90.1 \\
Programming & 50 & 89.3 & 23 & 92.0 & 73 & 90.1 \\
Supervision & 53 & 94.6 & 24 & 96.0 & 77 & 95.1 \\
Counseling/Mentoring & 44 & 78.6 & 24 & 96.0 & 68 & 83.9 \\
& & & & & & (continued)
\end{tabular}




\begin{tabular}{|c|c|c|c|c|c|c|}
\hline Training Topics & $\begin{array}{c}\text { RD } \\
\text { HEPC } \\
\mathrm{N} \\
\end{array}$ & $\begin{array}{c}\text { RD } \\
\text { HEPC } \\
\% \\
\end{array}$ & $\begin{array}{c}\text { RD } \\
\text { ACUHOI } \\
\mathrm{N}\end{array}$ & $\begin{array}{c}\text { RD } \\
\text { ACUHOI } \\
\% \\
\end{array}$ & $\begin{array}{c}\mathrm{RD} \\
\text { Total } \\
\mathrm{N} \\
\end{array}$ & $\begin{array}{c}\mathrm{RD} \\
\text { Total } \\
\% \\
\end{array}$ \\
\hline Student Conduct & 53 & 94.6 & 23 & 92.0 & 76 & 93.8 \\
\hline Facilities Management & 43 & 76.8 & 17 & 68.0 & 60 & 74.1 \\
\hline Safety and Security & 48 & 85.7 & 22 & 88.0 & 70 & 86.4 \\
\hline Crisis Management & 52 & 92.9 & 25 & 100.0 & 77 & 95.1 \\
\hline $\begin{array}{l}1^{\text {st }} \text { Year Course } \\
\text { Instruction }\end{array}$ & 7 & 12.5 & 8 & 32.0 & 15 & 18.5 \\
\hline Student Development & 38 & 67.9 & 18 & 72.0 & 56 & 69.1 \\
\hline Budget & 38 & 67.9 & 21 & 84.0 & 59 & 72.8 \\
\hline Other & 10 & 17.8 & 1 & 4.0 & 11 & 13.6 \\
\hline Total Answered & 56 & & 25 & & 81 & \\
\hline Skipped Question & 11 & & 10 & & 21 & \\
\hline
\end{tabular}

Administrators were asked to list the topics they covered in training for first year resident directors before the halls opened. Table 56 reflects that $100 \%(\mathrm{n}=40)$ provided training in "Student Conduct", 95\% (n=38) provided training in "Supervision", "Safety and Security", and "Crisis Management", and 90\% (n=36) were trained in "Programming." The HEPC and ACUHO-I survey results were somewhat similar in that at least $90 \%$ of the respondents indicated that resident directors were trained in "Student Conduct" and "Supervision". In comparing this information to the resident directors' information in Table 55, it appears administrators felt that they provided more training in areas that the resident directors did not feel that they were trained in such as "Safety and Security." Twelve administrators listed other topics with main themes that included "Diversity/Sensitivity Training", "Administrative Processes", "Social Justice", 
"Working with Other Units”, “Learning Communities”, "Residential Education Mission”, “Desk Operations", and "Advising."

Table 56

Topics Covered in $1^{\text {st }}$ Year Training Before Halls Opened Reported by Administrators

\begin{tabular}{|c|c|c|c|c|c|c|}
\hline Training Topics & $\begin{array}{c}\text { Admin. } \\
\text { HEPC } \\
\mathrm{N}\end{array}$ & $\begin{array}{c}\text { Admin. } \\
\text { HEPC } \\
\%\end{array}$ & $\begin{array}{c}\text { Admin. } \\
\text { ACUHOI } \\
\mathrm{N}\end{array}$ & $\begin{array}{c}\text { Admin. } \\
\text { ACUHOI } \\
\% \\
\end{array}$ & $\begin{array}{c}\text { Admin. } \\
\text { Total } \\
\mathrm{N}\end{array}$ & $\begin{array}{c}\text { Admin. } \\
\text { Total } \\
\% \\
\end{array}$ \\
\hline Daily Hall Operations & 20 & 90.9 & 15 & 83.3 & 35 & 87.5 \\
\hline Programming & 19 & 86.4 & 17 & 94.4 & 36 & 90.0 \\
\hline Supervision & 20 & 90.9 & 18 & 100.0 & 38 & 95.0 \\
\hline Counseling/Mentoring & 17 & 77.3 & 16 & 88.9 & 33 & 82.5 \\
\hline Student Conduct & 22 & 100.0 & 18 & 100.0 & 40 & 100.0 \\
\hline Facilities Management & 15 & 68.2 & 14 & 77.8 & 29 & 72.5 \\
\hline Safety and Security & 22 & 100.0 & 16 & 88.9 & 38 & 95.0 \\
\hline Crisis Management & 21 & 95.5 & 17 & 94.4 & 38 & 95.0 \\
\hline $\begin{array}{l}1^{\text {st }} \text { Year Course } \\
\text { Instruction }\end{array}$ & 6 & 27.3 & 1 & 5.6 & 7 & 17.5 \\
\hline Student Development & 17 & 77.3 & 14 & 77.8 & 31 & 77.5 \\
\hline Budget & 13 & 59.1 & 10 & 55.6 & 23 & 57.5 \\
\hline Other & 8 & 36.4 & 4 & 1.2 & 12 & 30.0 \\
\hline Total Answered & 22 & & 18 & & 40 & \\
\hline Skipped Question & 4 & & 2 & & 6 & \\
\hline
\end{tabular}

Table 57 reflects that the majority of resident directors rated their first year resident director training as "Very Valuable" with $43.2 \%(n=35)$ in this category. The HEPC and 
ACUHO-I results were not similar in that the majority of HEPC resident directors rated first year training as "Very Valuable" while the majority of ACUHO-I resident directors rated first year training as "Extremely Valuable."

Table 57

Resident Directors' Rating of $1^{\text {st }}$ Year Resident Director Training Before Halls Opened

\begin{tabular}{lcccccc}
\hline Value Rating & RD & RD & RD & RD & RD & RD \\
& HEPC & HEPC & ACUHOI & ACUHOI & Total \\
& N & $\%$ & N & $\begin{array}{c}\text { Total } \\
\%\end{array}$ \\
\hline Extremely Valuable & 12 & 21.4 & 11 & 44.0 & 23 & 28.4 \\
Very Valuable & 27 & 48.2 & 8 & 32.0 & 35 & 43.2 \\
Somewhat Valuable & 14 & 25.0 & 6 & 24.0 & 20 & 24.7 \\
Rarely Valuable & 0 & 0.0 & 0 & 0.0 & 0 & 0.0 \\
Not Valuable & 3 & 5.4 & 0 & 0.0 & 3 & 3.7 \\
Total Answered & 56 & & 25 & & 81 & \\
Skipped Question & 11 & & 10 & & & \\
\end{tabular}

Three HEPC resident directors indicated that they felt training was not valuable. Table 58 reflects the comments reported by two of the three on why the felt training was not valuable.

Table 58

Resident Directors' Comments on Why $1^{\text {st }}$ Year Training Not Valuable

RD HEPC Comments

1. "It was not that the topics listed that were covered were unnecessary, the training facilitators were just ineffective."

2. "It was very low level and not very interactive." 
Table 59 reflects that the majority of administrators rated first year resident director training as "Extremely Valuable" with 52.5\% $(\mathrm{n}=21)$ in this category. The HEPC and ACUHO-I survey results were similar in that the majority of administrators rated first year resident training as "Extremely Valuable."

Table 59

Administrators' Rating of $1^{\text {st }}$ Year Resident Director Training Before Halls Opened

\begin{tabular}{|c|c|c|c|c|c|c|}
\hline Value Rating & $\begin{array}{c}\text { Admin. } \\
\text { HEPC } \\
\mathrm{N}\end{array}$ & $\begin{array}{c}\text { Admin. } \\
\text { HEPC } \\
\%\end{array}$ & $\begin{array}{c}\text { Admin. } \\
\text { ACUHOI } \\
\mathrm{N}\end{array}$ & $\begin{array}{c}\text { Admin. } \\
\text { ACUHOI } \\
\%\end{array}$ & $\begin{array}{c}\text { Admin. } \\
\text { Total } \\
\text { N }\end{array}$ & $\begin{array}{c}\text { Admin. } \\
\text { Total } \\
\%\end{array}$ \\
\hline Extremely Valuable & 12 & 54.5 & 9 & 50.0 & 21 & 52.5 \\
\hline Very Valuable & 5 & 22.7 & 8 & 44.4 & 13 & 32.5 \\
\hline Somewhat Valuable & 4 & 18.2 & 1 & 5.6 & 5 & 12.5 \\
\hline Rarely Valuable & 0 & 0.0 & 0 & 0.0 & 0 & 0.0 \\
\hline Not Valuable & 1 & 4.5 & 0 & 0.0 & 1 & 2.5 \\
\hline Total Answered & 22 & & 18 & & 40 & \\
\hline Skipped Question & 4 & & 2 & & 6 & \\
\hline
\end{tabular}

One HEPC administrator indicated that they felt training before the halls opened was not valuable. Table 60 reflects the comment on why they felt training was not valuable. Table 60 Administrators' Comments on Why $1^{\text {st }}$ Year Training Not Valuable Admin. HEPC Comment

1. "It is not structured enough and starts whenever the employee starts, no matter when that is. It often does not include the information needed to run a hall on a daily basis." 
Resident directors were asked to indicate whether or not they participated in training after the residence halls opened during their first year as a resident director. Table 61 reflects that the majority indicated that they had participated in training after the halls opened with $63.6 \%(n=56)$ in this category. The HEPC and ACUHO-I survey results were similar in that the majority of first year resident directors participated in training after the residence halls opened. It should be noted that ACUHO-I resident directors were required to participate in training after the halls opened at a higher rate $(16.7 \%$ higher) than their HEPC peers.

Table 61

Resident Directors Provided with Training After Residence Halls Opened

\begin{tabular}{|c|c|c|c|c|c|c|}
\hline Participated & $\begin{array}{c}\text { RD } \\
\text { HEPC } \\
\mathrm{N}\end{array}$ & $\begin{array}{c}\text { RD } \\
\text { HEPC } \\
\% \\
\end{array}$ & $\begin{array}{c}\text { RD } \\
\text { ACUHOI } \\
\mathrm{N}\end{array}$ & $\begin{array}{c}\text { RD } \\
\text { ACUHOI } \\
\% \\
\end{array}$ & $\begin{array}{c}\text { RD } \\
\text { Total } \\
\mathrm{N}\end{array}$ & $\begin{array}{c}\text { RD } \\
\text { Total } \\
\% \\
\end{array}$ \\
\hline Yes & 35 & 58.3 & 21 & 75.0 & 56 & 63.6 \\
\hline No & 25 & 41.7 & 7 & 25.0 & 32 & 36.4 \\
\hline Total Answered & 60 & & 28 & & 88 & \\
\hline Skipped Question & 7 & & 7 & & 14 & \\
\hline
\end{tabular}

Resident directors who were not provided with training after the halls opened were asked if they felt additional training would have been valuable. Table 62 indicates that the majority felt additional training would have been valuable with $72.7 \%(\mathrm{n}=48)$ rating this category. The HEPC and ACUHO-I survey results were similar in that the majority of respondents felt that training after the residence halls opened would have been valuable. 
Table 62

If No Training Provided, Resident Directors Felt Additional Training Valuable

\begin{tabular}{lcccccc}
\hline Valuable & RD & RD & RD & RD & RD & RD \\
& HEPC & HEPC & ACUHOI & ACUHOI & Total & $\begin{array}{c}\text { Total } \\
\text { N }\end{array}$ \\
& N & $\%$ & N & $\%$ & N & $\%$ \\
\hline Yes & 33 & 73.3 & 15 & 71.4 & 48 & 72.7 \\
No & 12 & 26.7 & 6 & 28.6 & 18 & 27.3 \\
Total Answered & 45 & & 21 & & 66 & \\
Skipped Question & 22 & & 14 & & 36 &
\end{tabular}

Administrators were asked to indicate whether or not they provided training after the residence halls opened for first year resident directors. Table 63 reflects that the majority of administrators provided training for resident directors after the halls opened with $90.2 \%(\mathrm{n}=37)$ in this category. The HEPC and ACUHO-I survey results were similar in that the majority of respondents provided first year resident directors with training after the residence halls opened.

Table 63

Administrators who Provided RDs with Training After Halls Opened

\begin{tabular}{lcccccc}
\hline Training Provided & $\begin{array}{c}\text { Admin. } \\
\text { HEPC }\end{array}$ & $\begin{array}{c}\text { Admin. } \\
\text { HEPC } \\
\text { N }\end{array}$ & $\begin{array}{c}\text { Admin. } \\
\text { ACUHOI } \\
\text { Nes }\end{array}$ & $\begin{array}{c}\text { Admin. } \\
\text { ACUHOI } \\
\%\end{array}$ & $\begin{array}{c}\text { Admin. } \\
\text { Total } \\
\text { N }\end{array}$ & $\begin{array}{c}\text { Admin. } \\
\text { Total } \\
\%\end{array}$ \\
No & 20 & 90.9 & 17 & 89.5 & 37 & 90.2 \\
Total Answered & 22 & 9.1 & 2 & 10.5 & 4 & 9.8 \\
Skipped Question & 4 & & 19 & & 41 & \\
& & & 1 & & 5 & \\
\hline
\end{tabular}


Resident directors were asked to list the topics covered during training during after the residence halls opened. Table 64 reflects that $65.4 \%(n=34)$ were trained in "Student Conduct" and 59.6\% (n=31) were trained in "Supervision" and "Crisis Management." The HEPC and ACUHO-I survey results were similar in the ranking of the training topics. Eleven resident directors listed other topics with main themes that included "Advising Student Organization”, “Service Learning", "Personal/Professional Development", "Presentation”, "Healthy Living”, and "Department Initiatives".

Table 64

Topics Covered in Training After Residence Halls Opened

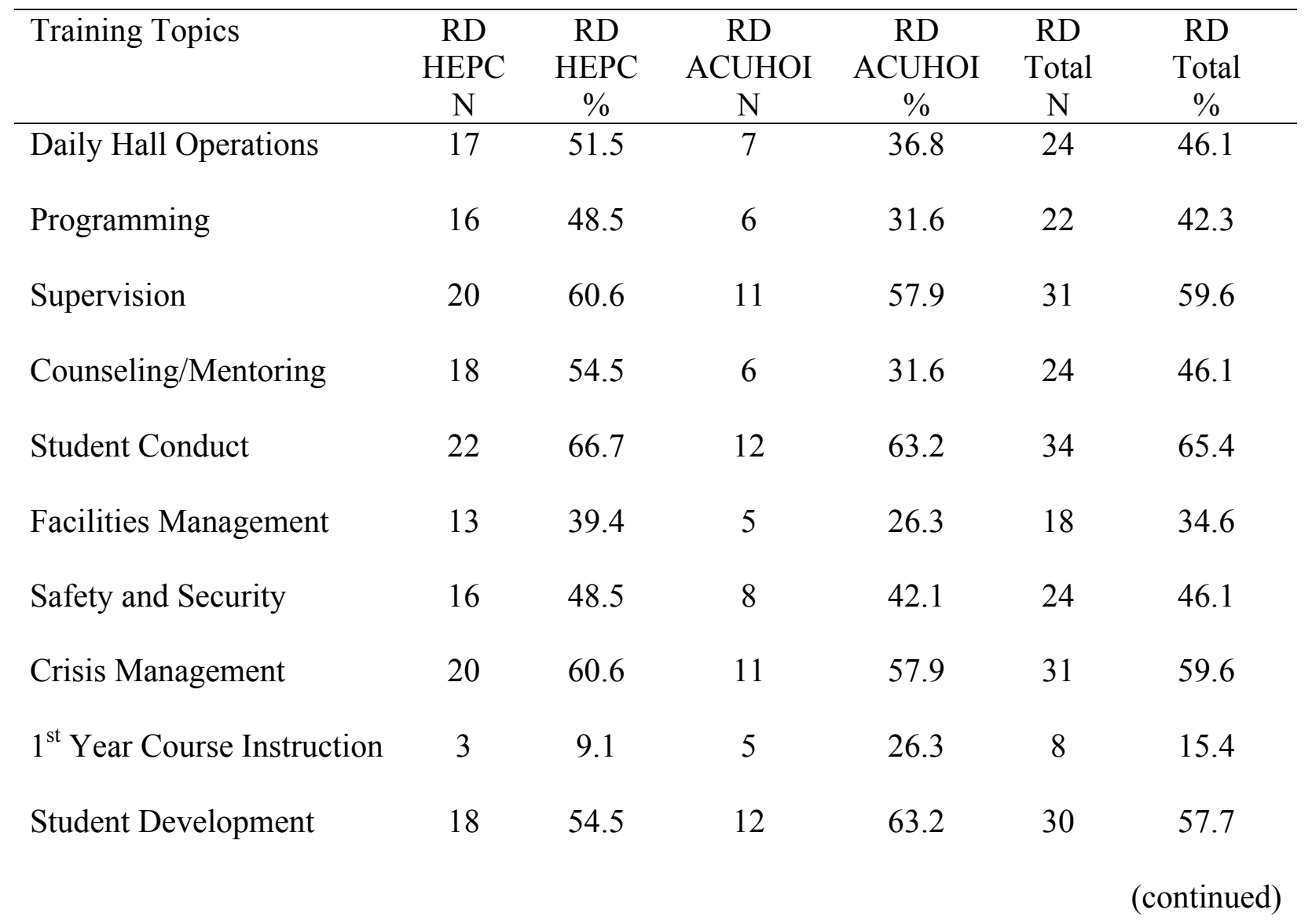




\begin{tabular}{|c|c|c|c|c|c|c|}
\hline Training Topics & $\begin{array}{c}\mathrm{RD} \\
\mathrm{HEPC} \\
\mathrm{N}\end{array}$ & $\begin{array}{c}\text { RD } \\
\text { HEPC } \\
\%\end{array}$ & $\begin{array}{c}\text { RD } \\
\text { ACUHOI } \\
\mathrm{N}\end{array}$ & $\begin{array}{c}\text { RD } \\
\text { ACUHOI } \\
\%\end{array}$ & $\begin{array}{c}\mathrm{RD} \\
\text { Total } \\
\mathrm{N}\end{array}$ & $\begin{array}{c}\mathrm{RD} \\
\text { Total } \\
\%\end{array}$ \\
\hline Budget & 15 & 45.5 & 6 & 31.6 & 21 & 40.4 \\
\hline Other & 7 & 21.2 & 4 & 21.0 & 11 & 21.1 \\
\hline Total Answered & 33 & & 19 & & 52 & \\
\hline Skipped Question & 34 & & 16 & & 50 & \\
\hline
\end{tabular}

Administrators were asked to list the topics covered during training for resident directors after the residence halls opened. Table 65 reflects that $78.1 \%(n=25)$ trained resident directors in "Supervision" and 75\% ( $\mathrm{n}=24)$ trained in "Crisis Management." The HEPC and ACUHO-I survey results were similar in the ranking of "Supervision" and "Crisis Management" as the main topics covered in training. Twelve administrators listed other topics to include "Current Trends and Issues", “Assessment”, "In Service”, "Needs Based Training”, "University Culture”, "Social Justice", "Advising", and subjects not required to open the hall (i.e., room changes, hall council, etc.).

Table 65

Topics Covered in Training After Residence Halls Open Reported by Administrators

\begin{tabular}{|c|c|c|c|c|c|c|}
\hline Training Topics & $\begin{array}{c}\text { Admin. } \\
\text { HEPC } \\
\mathrm{N}\end{array}$ & $\begin{array}{c}\text { Admin. } \\
\text { HEPC } \\
\%\end{array}$ & $\begin{array}{l}\text { Admin. } \\
\text { ACUHOI } \\
\mathrm{N}\end{array}$ & $\begin{array}{l}\text { Admin. } \\
\text { ACUHOI } \\
\%\end{array}$ & $\begin{array}{c}\text { Admin } \\
\text { Total } \\
\text { N }\end{array}$ & $\begin{array}{c}\text { Admin. } \\
\text { Total } \\
\%\end{array}$ \\
\hline Daily Hall Operations & 8 & 44.4 & 8 & 57.1 & 16 & 50.0 \\
\hline Programming & 9 & 50.0 & 7 & 50.0 & 16 & 50.0 \\
\hline Supervision & 13 & 72.2 & 12 & 85.7 & 25 & $\begin{array}{c}78.1 \\
\text { (continued) }\end{array}$ \\
\hline
\end{tabular}




\begin{tabular}{lcccccc}
\hline Training Topics & $\begin{array}{c}\text { Admin. } \\
\text { HEPC }\end{array}$ & $\begin{array}{c}\text { Admin. } \\
\text { HEPC }\end{array}$ & $\begin{array}{c}\text { Admin. } \\
\text { ACUHOI }\end{array}$ & $\begin{array}{c}\text { Admin. } \\
\text { ACUHOI }\end{array}$ & $\begin{array}{c}\text { Admin. } \\
\text { Total } \\
\text { N }\end{array}$ & $\begin{array}{c}\text { Admin. } \\
\text { Total } \\
\%\end{array}$ \\
\hline Counseling/Mentoring & 8 & 44.4 & 4 & 28.6 & 12 & 37.5 \\
Student Conduct & 9 & 50.0 & 7 & 50.0 & 16 & 50.0 \\
Facilities Management & 7 & 38.9 & 4 & 28.6 & 11 & 34.4 \\
Safety and Security & 12 & 66.7 & 8 & 57.1 & 20 & 62.5 \\
Crisis Management & 13 & 72.2 & 11 & 78.6 & 24 & 75.0 \\
$1^{\text {st }}$ Year Course Instruction & 4 & 22.2 & 2 & 14.3 & 6 & 18.7 \\
Student Development & 8 & 44.4 & 8 & 57.1 & 16 & 50.0 \\
Budget & 6 & 33.3 & 3 & 21.4 & 9 & 28.1 \\
Other & 8 & 44.4 & 5 & 35.7 & 12 & 37.5 \\
Total Answered & 18 & & 14 & & 32 & \\
Skipped Question & 8 & & 6 & & 14 & \\
\hline
\end{tabular}

Resident directors were asked to rate their training after the residence halls opened. Table 66 reflects that the majority of the resident directors rated training as "Very Valuable" with $41 \%(n=23)$ rating this category. The HEPC and AUCHO-I results were not similar in that the majority of HEPC resident directors rated training as "Somewhat Valuable" while the majority of ACUHO-I resident directors rated training as "Very Valuable." 
Table 66

Resident Directors' Rating of $1^{\text {st }}$ Year Training After Halls Opened

\begin{tabular}{|c|c|c|c|c|c|c|}
\hline Value Rating & $\begin{array}{c}\text { RD } \\
\text { HEPC } \\
\mathrm{N}\end{array}$ & $\begin{array}{c}\text { RD } \\
\text { HEPC } \\
\%\end{array}$ & $\begin{array}{c}\text { RD } \\
\text { ACUHOI } \\
\mathrm{N}\end{array}$ & $\begin{array}{c}\text { RD } \\
\text { ACUHOI } \\
\% \\
\end{array}$ & $\begin{array}{c}\text { RD } \\
\text { Total } \\
\mathrm{N}\end{array}$ & $\begin{array}{c}\text { RD } \\
\text { Total } \\
\% \\
\end{array}$ \\
\hline Extremely Valuable & 4 & 11.4 & 4 & 19.0 & 8 & 14.3 \\
\hline Very Valuable & 13 & 37.1 & 10 & 47.6 & 23 & 41.0 \\
\hline Somewhat Valuable & 16 & 45.7 & 6 & 28.6 & 22 & 39.3 \\
\hline Rarely Valuable & 0 & 0.0 & 1 & 4.8 & 1 & 1.8 \\
\hline Not Valuable & 2 & 5.7 & 0 & 0.0 & 2 & 3.6 \\
\hline Total Answered & 35 & & 21 & & 56 & \\
\hline Skipped Question & 32 & & 14 & & 46 & \\
\hline
\end{tabular}

Two HEPC resident directors indicated that they felt training was not valuable. Table 67 reflects the comment from one of them on why they felt training was not valuable.

Table 67

Resident Directors' Comments on Why Training After Halls Opened Not Valuable RD HEPC Comments

1. "The training was repetitive and also low level."

Administrators were asked to rate resident director training after the residence halls opened. Table 68 reflects that the majority of administrators rated training as "Very Valuable" with $40.6 \%(n=15)$ rating this category. The majority of HEPC administrators rated training as "Extremely Valuable" while the majority of and ACUHO-I administrators rated training as "Very Valuable." 
Table 68

Administrators’ Rating of Resident Director Training After Halls Opened

\begin{tabular}{|c|c|c|c|c|c|c|}
\hline Value Rating & $\begin{array}{c}\text { Admin. } \\
\text { HEPC } \\
\mathrm{N}\end{array}$ & $\begin{array}{c}\text { Admin. } \\
\text { HEPC } \\
\%\end{array}$ & $\begin{array}{c}\text { Admin. } \\
\text { ACUHOI } \\
\mathrm{N}\end{array}$ & $\begin{array}{c}\text { Admin. } \\
\text { ACUHOI } \\
\%\end{array}$ & $\begin{array}{c}\text { Admin. } \\
\text { Total } \\
\text { N }\end{array}$ & $\begin{array}{c}\text { Admin. } \\
\text { Total } \\
\%\end{array}$ \\
\hline Extremely Valuable & 9 & 45.0 & 3 & 17.6 & 12 & 32.4 \\
\hline Very Valuable & 5 & 25.0 & 10 & 58.8 & 15 & 40.6 \\
\hline Somewhat Valuable & 6 & 30.0 & 4 & 23.5 & 10 & 27.0 \\
\hline Rarely Valuable & 0 & 0.0 & 0 & 0.0 & 0 & 0.0 \\
\hline Not Valuable & 0 & 0.0 & 0 & 0.0 & 0 & 0.0 \\
\hline Total Answered & 20 & & 17 & & 37 & \\
\hline Skipped Question & 6 & & 3 & & 9 & \\
\hline
\end{tabular}

Resident directors were asked if they were required to participate in training on a regular basis. Table 69 reflects that the majority of resident directors were required to participate in training on a regular basis with $71.6 \%(\mathrm{n}=63)$ in this category. The HEPC and ACUHO-I survey results were similar in that the majority of respondents indicated that they were required to participate in training on a regular basis. It should be noted that ACUHO-I resident directors were required to participate in training at a higher rate $(15.4 \%$ higher $)$ than their HEPC peers. Table 69

Resident Directors Required to Participate in Training on Regular Basis

\begin{tabular}{lcccccc}
\hline Participated & RD & RD & RD & RD & RD & RD \\
& HEPC & HEPC & ACUHOI & ACUHOI & Total & Total \\
& N & $\%$ & N & $\%$ & N & $\%$ \\
\hline Yes & 40 & 66.7 & 23 & 82.1 & 63 & 71.6 \\
& & & & & & (continued)
\end{tabular}




\begin{tabular}{|c|c|c|c|c|c|c|}
\hline Participated & $\begin{array}{c}\text { RD } \\
\text { HEPC } \\
N\end{array}$ & $\begin{array}{c}\text { RD } \\
\text { HEPC } \\
\%\end{array}$ & $\begin{array}{c}\mathrm{RD} \\
\mathrm{ACUHOI} \\
\mathrm{N}\end{array}$ & $\begin{array}{c}\mathrm{RD} \\
\mathrm{ACUHOI} \\
\%\end{array}$ & $\begin{array}{c}\mathrm{RD} \\
\text { Total } \\
\mathrm{N}\end{array}$ & $\begin{array}{c}\mathrm{RD} \\
\text { Total } \\
\%\end{array}$ \\
\hline No & 20 & 33.3 & 5 & 17.9 & 25 & 28.4 \\
\hline Total Answered & 60 & & 28 & & 88 & \\
\hline Skipped Question & 7 & & 7 & & 14 & \\
\hline
\end{tabular}

Administrators were asked if resident directors were required to participate in training on a regular basis. Table 70 reflects that the majority of administrators required resident directors to participate in training on a regular basis with $69.2 \%(\mathrm{n}=27)$ in this category. The HEPC and ACUHO-I survey results were similar in that the majority of respondents indicated that they required resident directors to participate in training on a regular basis.

Table 70

Administrators who Required RDs to Participate in Training on Regular Basis

\begin{tabular}{|c|c|c|c|c|c|c|}
\hline $\begin{array}{l}\text { Participation } \\
\text { Required }\end{array}$ & $\begin{array}{c}\text { Admin. } \\
\text { HEPC } \\
\mathrm{N}\end{array}$ & $\begin{array}{c}\text { Admin. } \\
\text { HEPC } \\
\%\end{array}$ & $\begin{array}{c}\text { Admin. } \\
\text { ACUHOI } \\
\mathrm{N}\end{array}$ & $\begin{array}{c}\text { Admin. } \\
\text { ACUHOI } \\
\%\end{array}$ & $\begin{array}{c}\text { Admin. } \\
\text { Total } \\
\text { N }\end{array}$ & $\begin{array}{c}\text { Admin } \\
\text { Total } \\
\%\end{array}$ \\
\hline Yes & 15 & 71.4 & 12 & 66.7 & 27 & 69.2 \\
\hline No & 6 & 28.6 & 6 & 33.3 & 12 & 30.8 \\
\hline Total Answered & 21 & & 18 & & 39 & \\
\hline Skipped Question & 5 & & 2 & & 7 & \\
\hline
\end{tabular}

Resident directors were asked to list how often formal training on a regular basis occurred. Table 71 reflects that the majority of resident directors participated in "Monthly" training on a regular basis with $48.4 \%(\mathrm{n}=30)$ in this category. The HEPC and ACUHO-I survey results were similar in that the majority of respondents indicated that they were required to 
participate in "Monthly" training on a regular basis. However, HEPC resident director responses reflected a considerably lower rate $(47.5 \%$ lower) than their ACUHO-I peers.

Table 71

Frequency of Formal Training Provided on Regular Basis

\begin{tabular}{|c|c|c|c|c|c|c|}
\hline Frequency & $\begin{array}{c}\text { RD } \\
\text { HEPC } \\
N\end{array}$ & $\begin{array}{c}\text { RD } \\
\text { HEPC } \\
\% \\
\end{array}$ & $\begin{array}{c}\mathrm{RD} \\
\text { ACUHOI } \\
\mathrm{N}\end{array}$ & $\begin{array}{c}\text { RD } \\
\text { ACUHOI } \\
\% \\
\end{array}$ & $\begin{array}{c}\mathrm{RD} \\
\text { Total } \\
\mathrm{N}\end{array}$ & $\begin{array}{c}\mathrm{RD} \\
\text { Total } \\
\% \\
\end{array}$ \\
\hline Weekly & 4 & 10.3 & 2 & 8.7 & 6 & 9.7 \\
\hline Monthly & 12 & 30.8 & 18 & 78.3 & 30 & 48.4 \\
\hline Quarterly & 7 & 17.9 & 2 & 8.7 & 9 & 14.5 \\
\hline Semi-Annually & 11 & 28.2 & 1 & 4.3 & 12 & 19.3 \\
\hline Annually & 5 & 12.8 & 0 & 0.0 & 5 & 8.1 \\
\hline Total Answered & 39 & & 23 & & 62 & \\
\hline Skipped Question & 28 & & 12 & & 40 & \\
\hline
\end{tabular}

Administrators were asked to list how often formal training was provided to resident directors on a regular basis. Table 72 reflects that the majority of resident directors were provided with formal "Monthly" training on a regular basis with $42.9 \%(\mathrm{n}=12)$ in this category. The HEPC and ACUHO-I survey results were similar in that the majority of respondents indicated that they required resident directors to participate in "Monthly" training on a regular basis. However, HEPC administrator responses reflected a considerably lower rate ( $27 \%$ lower) than their ACUHO-I peers. 
Table 72

Frequency of Formal Training Provided on Regular Basis Reported by Administrators

\begin{tabular}{lcccccc}
\hline Frequency & $\begin{array}{c}\text { Admin. } \\
\text { HEPC } \\
\text { Neekly }\end{array}$ & $\begin{array}{c}\text { Admin. } \\
\text { HEPC }\end{array}$ & $\begin{array}{c}\text { Admin. } \\
\text { ACUHOI }\end{array}$ & $\begin{array}{c}\text { Admin. } \\
\text { ACUHOI } \\
\%\end{array}$ & $\begin{array}{c}\text { Admin. } \\
\text { Total } \\
\text { N }\end{array}$ & $\begin{array}{c}\text { Admin. } \\
\text { Total } \\
\%\end{array}$ \\
Monthly & 4 & 25.0 & 0 & 0.0 & 4 & 14.3 \\
Quarterly & 5 & 31.3 & 7 & 58.3 & 12 & 42.9 \\
Semi-Annually & 3 & 18.8 & 2 & 16.7 & 5 & 17.8 \\
Annually & 2 & 12.5 & 1 & 8.3 & 3 & 10.7 \\
Total Answered & 2 & 12.5 & 2 & 16.7 & 4 & 14.3 \\
Skipped Question & 16 & & 12 & & 28 & \\
\end{tabular}

Resident directors were asked if they felt appropriately trained to handle their position responsibilities. Table 73 reflects that the majority of the resident directors felt that they were appropriately trained with $86.4 \%(\mathrm{n}=76)$ rating this category. The HEPC and ACUHO-I survey results were similar in that the majority of respondents indicated that they felt appropriately trained to handle their responsibilities of their position.

Table 73

Resident Directors who Felt Appropriately Trained to Handle Responsibilities

\begin{tabular}{lcccccc}
\hline $\begin{array}{l}\text { Appropriately } \\
\text { Trained }\end{array}$ & RD & RD & RD & RD & RD & RD \\
& HEPC & HEPC & ACUHOI & ACUHOI & Total \\
$\%$ & N & $\%$ & N & Total \\
Yes & 49 & 81.7 & 27 & 96.4 & 76 & 86.4 \\
No & 11 & 18.3 & 1 & 3.6 & 12 & 13.6 \\
& & & & & & (continued)
\end{tabular}




\begin{tabular}{lcccccc}
\hline Appropriately & RD & RD & RD & RD & RD & RD \\
Trained & HEPC & HEPC & ACUHOI & ACUHOI & Total & $\begin{array}{c}\text { Total } \\
\text { N }\end{array}$ \\
& N & $\%$ & N & $\%$ & N & $\%$ \\
\hline Total Answered & 60 & & 28 & & 88 & \\
Skipped Question & 7 & & 7 & & 14 & \\
\hline
\end{tabular}

Administrators were asked if they felt the resident directors were appropriately trained to handle their position responsibilities. Table 74 reflects that the majority of administrators felt the resident directors were able to handle their responsibilities with $97.5 \%(n=39)$ rating this category. The HEPC and ACUHO-I survey results were similar in that the majority of respondents indicated that they felt resident directors at their institutions were appropriately trained to handle their responsibilities of their position.

Table 74

Administrators who Felt Resident Directors Appropriately Trained to Handle Responsibilities

\begin{tabular}{|c|c|c|c|c|c|c|}
\hline $\begin{array}{l}\text { Appropriately } \\
\text { Trained }\end{array}$ & $\begin{array}{c}\text { Admin. } \\
\text { HEPC } \\
\text { N }\end{array}$ & $\begin{array}{c}\text { Admin. } \\
\text { HEPC } \\
\% \\
\end{array}$ & $\begin{array}{c}\text { Admin. } \\
\text { ACUHOI } \\
\mathrm{N}\end{array}$ & $\begin{array}{c}\text { Admin. } \\
\text { ACUHOI } \\
\%\end{array}$ & $\begin{array}{c}\text { Admin. } \\
\text { Total } \\
\text { N }\end{array}$ & $\begin{array}{c}\text { Admin. } \\
\text { Total } \\
\%\end{array}$ \\
\hline Yes & 21 & 95.5 & 18 & 100.0 & 39 & 97.5 \\
\hline No & 1 & 4.5 & 0 & 0.0 & 1 & 2.5 \\
\hline Total Answered & 22 & & 18 & & 40 & \\
\hline Skipped Question & 4 & & 2 & & 6 & \\
\hline
\end{tabular}

Of the 12 resident directors who felt they were not appropriately trained to handle their responsibilities, they were asked to list the areas in which they felt additional training was needed. Table 75 reflects that $66.7 \%(\mathrm{n}=8)$ needed training in "Counseling/Mentoring" and "Student Conduct" and 58.3\% (n=7) needed training in "Supervision" and "Crisis Management." 
The HEPC and ACUHO-I survey results were somewhat similar in that the majority of respondents indicated that needed additional training in "Supervision", "Counseling/Mentoring", "Crisis Management" and "Student Conduct." However, HEPC resident directors felt additional training in "Daily Hall Operations" was needed while the ACUHO-I resident directors felt additional training in "Safety and Security" was needed.

Table 75

Topics in Which Resident Directors Felt Additional Training Needed

\begin{tabular}{|c|c|c|c|c|c|c|}
\hline Topics & $\begin{array}{c}\text { RD } \\
\text { HEPC } \\
\mathrm{N}\end{array}$ & $\begin{array}{c}\text { RD } \\
\text { HEPC } \\
\%\end{array}$ & $\begin{array}{c}\text { RD } \\
\text { ACUHOI } \\
\mathrm{N}\end{array}$ & $\begin{array}{c}\text { RD } \\
\text { ACUHOI } \\
\%\end{array}$ & $\begin{array}{c}\mathrm{RD} \\
\text { Total } \\
\mathrm{N}\end{array}$ & $\begin{array}{c}\text { RD } \\
\text { Total } \\
\%\end{array}$ \\
\hline Daily Hall Operations & 6 & 54.5 & 0 & 0.0 & 6 & 50.0 \\
\hline Programming & 3 & 27.3 & 0 & 0.0 & 3 & 25.0 \\
\hline Supervision & 6 & 54.5 & 1 & 100.0 & 7 & 58.3 \\
\hline Counseling/Mentoring & 7 & 63.6 & 1 & 100.0 & 8 & 66.7 \\
\hline Student Conduct & 7 & 63.6 & 1 & 100.0 & 8 & 66.7 \\
\hline Facilities Management & 3 & 27.3 & 0 & 0.0 & 3 & 25.0 \\
\hline Safety and Security & 1 & 9.1 & 1 & 100.0 & 2 & 16.7 \\
\hline Crisis Management & 6 & 54.5 & 1 & 100.0 & 7 & 58.3 \\
\hline $\begin{array}{l}1^{\text {st }} \text { Year Course } \\
\text { Instruction }\end{array}$ & 2 & 18.2 & 0 & 0.0 & 2 & 16.7 \\
\hline Student Development & 4 & 36.4 & 1 & 100.0 & 5 & 41.7 \\
\hline Budget & 4 & 36.4 & 0 & 0.0 & 4 & 33.3 \\
\hline Other & 2 & & 0 & & 2 & 16.7 \\
\hline Total Answered & 11 & & 1 & & 12 & \\
\hline Skipped Question & 56 & & 34 & & 90 & \\
\hline
\end{tabular}


Only one administrator felt that the resident directors were not appropriately trained to handle their responsibilities. They were asked to list the areas in which they felt additional training was needed. Table 76 reflects that they felt additional needed training was needed in "Daily Hall Operations", "Counseling/Mentoring," and "Supervision.”

Table 76

Topics in Which Administrators Felt Additional Training Needed

\begin{tabular}{|c|c|c|c|c|c|c|}
\hline Topics & $\begin{array}{c}\text { Admin. } \\
\text { HEPC } \\
\mathrm{N}\end{array}$ & $\begin{array}{c}\text { Admin. } \\
\text { HEPC } \\
\%\end{array}$ & $\begin{array}{c}\text { Admin. } \\
\text { ACUHOI } \\
\mathrm{N}\end{array}$ & $\begin{array}{c}\text { Admin. } \\
\text { ACUHOI } \\
\%\end{array}$ & $\begin{array}{c}\text { Admin. } \\
\text { Total } \\
\text { N }\end{array}$ & $\begin{array}{c}\text { Admin. } \\
\text { Total } \\
\%\end{array}$ \\
\hline Daily Hall Operations & 1 & 100.0 & 0 & 0.0 & 1 & 100.0 \\
\hline Programming & 0 & 0.0 & 0 & 0.0 & 0 & 0.0 \\
\hline Supervision & 1 & 100.0 & 0 & 0.0 & 1 & 100.0 \\
\hline Counseling/Mentoring & 1 & 100.0 & 0 & 0.0 & 1 & 100.0 \\
\hline Student Conduct & 0 & 0.0 & 0 & 0.0 & 0 & 0.0 \\
\hline Facilities Management & 0 & 0.0 & 0 & 0.0 & 0 & 0.0 \\
\hline Safety and Security & 0 & 0.0 & 0 & 0.0 & 0 & 0.0 \\
\hline Crisis Management & 0 & 0.0 & 0 & 0.0 & 0 & 0.0 \\
\hline $\begin{array}{l}1^{\text {st }} \text { Year Course } \\
\text { Instruction }\end{array}$ & 0 & 0.0 & 0 & 0.0 & 0 & 0.0 \\
\hline Student Development & 0 & 0.0 & 0 & 0.0 & 0 & 0.0 \\
\hline Budget & 0 & 0.0 & 0 & 0.0 & 0 & 0.0 \\
\hline Other & 0 & & 1 & & 1 & \\
\hline Total Answered & 1 & & 1 & & 2 & \\
\hline Skipped Question & 25 & & 20 & & 45 & \\
\hline
\end{tabular}


Table 77

Resident Directors' Additional Comments Related to Recruitment or Training

Sample of Resident Directors' Comments with Recurring Themes

1. "RDs don't always have to be RAs in college. Recruit people who can handle stress."

2. "Much is learned experientially once the position begins. Thus, experiential training is likely most beneficial."

3. "I think it is important to know that there is no way that someone can be trained on EVERYTHING that they may need to know prior to the job, sometimes our jobs are just that we react to things that come up and we need to work through it."

4. "I think that taking a step back during what can be very hectic training schedules and meeting with a direct supervisor to see how everything is sinking in is incredibly impactful for me."

5. "It is important to go over things one on one with someone who knows what they are doing... Going over things in powerpoints eight hours a day for weeks is not helpful in learning hall operations. It is too much to take in unless you are actually walking someone through it while they are doing it."

6. "There definitely needs to be constant opportunities for professional and personal development. Sessions, workshops, conferences, etc. As well as adequate time before the res-halls open to prepare and settle in."

7. "I believe that training HAS to be administered throughout the course of the year. You cannot learn everything in a month and it is important to note that sometimes certain things don't come up until after October..... I think that through a monthly two hour training we are able to learn a lot more."

8. "At my institution, training for Residence Hall Coordinators spans 4 weeks and goes for the whole work week (i.e. 40-hours). Residence Hall Coordinators begin at the beginning of July so they can spend a month training, then a week finalizing student staff training, and just over a week of student staff training before students move-in. In addition to weekly "business meetings," these business meetings take the form of professional development meetings, facilitated by other hall coordinators, area coordinators, and campus colleagues and partners."

9. "Formal training is necessary for resident directors prior to the arrival of RAs and the opening of the building. Resident Directors need to be able to be completely competent and functional from the first day they have a staff and residents."

10. "It is important to go over the Daily responsibilities and make that part of a work life balance conversation. There will be a number of weeks you work late or more then 40 but that is the nature of the field but if you are consistently around or over 60 hours you have a higher chance of burning out." 
Table 78

Administrators' Additional Comments Related to Recruitment or Training

Sample of Administrators' Comments with Recurring Themes

1. "In creating a training "curriculum", be aware of the order that the training sessions come in, as well as the fact that your staff may be overwhelmed by alot of the information. A manual that a staff member can review on their own is very helpful when all of the acronyms and "well known important names" of people are thrown around at meetings"

2. "You can prepare and train a hall director to carry out any procedure, but you can't train them to have good judgement, be ethical and have good integrity. If you hire for those traits, your training will be successful."

3. "Be honest about who you are, what your institution values, and how folks will spend their time, then you'll have a good fit!"

4. "Being able to directly tie training to mission makes it relevant"

\section{Research Questions Two and Three}

Research Question Two asked "How likely is a resident director to be retained based on the institution's organizational culture?" This was further analyzed by asking "What types of professional development opportunities exist?", "What type of mentoring occurs?", and "What types of rewards and benefits are offered?".

Research Question Three asked "How do ACUHO-I best practice institutions compare to WVU's HEPC peer institutions?"

\section{Comparison of Resident Directors Retention and Institutional Culture}

Administrators were asked to list how many full-time resident directors they had on staff. Table 79 reflects that the majority had between 11-15 full-time resident directors on staff with $48.7 \%(n=19)$ within this category. The HEPC and ACUHO-I survey results were similar in that the majority of respondents had 11-15 full-time resident directors on staff, however ACUHO-I had a greater percentage of 16-20 resident directors on staff than their HEPC peers. 
Table 79

Number of Full-Time Resident Directors on Staff

\begin{tabular}{|c|c|c|c|c|c|c|}
\hline No. of RDs & $\begin{array}{c}\text { Admin. } \\
\text { HEPC } \\
\mathrm{N}\end{array}$ & $\begin{array}{c}\text { Admin. } \\
\text { HEPC } \\
\%\end{array}$ & $\begin{array}{c}\text { Admin. } \\
\text { ACUHOI } \\
\mathrm{N}\end{array}$ & $\begin{array}{c}\text { Admin. } \\
\text { ACUHOI } \\
\%\end{array}$ & $\begin{array}{c}\text { Admin. } \\
\text { Total } \\
\text { N }\end{array}$ & $\begin{array}{c}\text { Admin. } \\
\text { Total } \\
\%\end{array}$ \\
\hline $0-5$ & 1 & 4.8 & 1 & 5.6 & 2 & 5.1 \\
\hline $6-10$ & 4 & 19.1 & 4 & 22.2 & 8 & 20.6 \\
\hline $11-15$ & 12 & 57.1 & 7 & 38.9 & 19 & 48.7 \\
\hline $16-20$ & 2 & 9.5 & 6 & 33.3 & 8 & 20.5 \\
\hline More than 20 & 2 & 9.5 & 0 & 0.0 & 2 & 5.1 \\
\hline Total Answered & 21 & & 18 & & 39 & \\
\hline Skipped Question & 5 & & 2 & & 7 & \\
\hline
\end{tabular}

Administrators were asked to list how many years of experience resident directors had.

Table 80 reflects that the most common response was "1 Year or Less" experience with 36.4\% $(n=171)$ within this category. The HEPC and ACUHO-I survey results were similar in that the most common response was that resident directors had "1 Year or Less" experience.

Table 80

Years of Experience of Resident Directors on Staff

\begin{tabular}{|c|c|c|c|c|c|c|}
\hline Years & $\begin{array}{c}\text { Admin. } \\
\text { HEPC } \\
\mathrm{N}\end{array}$ & $\begin{array}{c}\text { Admin. } \\
\text { HEPC } \\
\%\end{array}$ & $\begin{array}{l}\text { Admin. } \\
\text { ACUHOI } \\
\mathrm{N}\end{array}$ & $\begin{array}{c}\text { Admin. } \\
\text { ACUHOI } \\
\%\end{array}$ & $\begin{array}{c}\text { Admin. } \\
\text { Total } \\
\mathrm{N}\end{array}$ & $\begin{array}{c}\text { Admin. } \\
\text { Total } \\
\%\end{array}$ \\
\hline 1 Year or Less & 83 & 32.4 & 88 & 41.1 & 171 & 36.4 \\
\hline 2 Years & 48 & 18.8 & 43 & 20.1 & 91 & 19.4 \\
\hline
\end{tabular}




\begin{tabular}{lcccccc}
\hline Years & $\begin{array}{c}\text { Admin. } \\
\text { HEPC } \\
\text { N }\end{array}$ & $\begin{array}{c}\text { Admin. } \\
\text { HEPC } \\
\%\end{array}$ & $\begin{array}{c}\text { Admin. } \\
\text { ACUHOI } \\
\mathrm{N}\end{array}$ & $\begin{array}{c}\text { Admin. } \\
\text { ACUHOI } \\
\%\end{array}$ & $\begin{array}{c}\text { Admin. } \\
\text { Total } \\
\mathrm{N}\end{array}$ & $\begin{array}{c}\text { Admin. } \\
\text { Total } \\
\%\end{array}$ \\
\hline 3 Years & 37 & 14.4 & 41 & 19.2 & 78 & 16.6 \\
4 Years & 54 & 21.1 & 25 & 11.7 & 79 & 16.8 \\
5 Years or More & 34 & 13.3 & 17 & 7.9 & 51 & 10.8 \\
Total & 256 & & 214 & & 470 & \\
\hline
\end{tabular}

Table 81 reflects that the majority of resident directors were "Highly Likely" to continue as a resident director at their current institution the following year with $36.8 \%(\mathrm{n}=32)$ rating this category. The HEPC and ACUHO-I survey results were similar in that the majority of respondents indicated that it was "Highly Likely" for the resident director to remain at their current institution the following year.

Table 81

Likeliness of Resident Directors to Continue Next Year at Current Institution

\begin{tabular}{|c|c|c|c|c|c|c|}
\hline Likeliness Rating & $\begin{array}{c}\text { RD } \\
\text { HEPC } \\
\mathrm{N}\end{array}$ & $\begin{array}{c}\text { RD } \\
\text { HEPC } \\
\% \\
\end{array}$ & $\begin{array}{c}\text { RD } \\
\text { ACUHOI } \\
\mathrm{N}\end{array}$ & $\begin{array}{c}\text { RD } \\
\text { ACUHOI } \\
\% \\
\end{array}$ & $\begin{array}{c}\mathrm{RD} \\
\text { Total } \\
\mathrm{N} \\
\end{array}$ & $\begin{array}{c}\mathrm{RD} \\
\text { Total } \\
\% \\
\end{array}$ \\
\hline Highly Likely & 23 & 39.0 & 9 & 32.1 & 32 & 36.8 \\
\hline Somewhat Likely & 6 & 10.2 & 4 & 14.3 & 10 & 11.5 \\
\hline Neutral or Unsure & 15 & 25.4 & 4 & 14.3 & 19 & 21.8 \\
\hline Somewhat Unlikely & 6 & 10.2 & 3 & 10.7 & 9 & 10.3 \\
\hline Highly Unlikely & 9 & 15.3 & 8 & 28.6 & 17 & 19.6 \\
\hline Total Answered & 59 & & 28 & & 87 & \\
\hline Skipped Question & 8 & & 7 & & 15 & \\
\hline
\end{tabular}


Table 82 reflects that the most common response was for resident directors to continue as a resident director at their current institution " 1 Year or Less" with $29.6 \%(n=21)$ rating this category. The HEPC and ACUHO-I survey results were not similar in that the most common response for HEPC resident directors was to continue "1 Year or Less" while the most common response of ACUHO-I resident directors was to continue "3 Years."

Table 82

Years Resident Directors Plan to Continue at Current Institution

\begin{tabular}{|c|c|c|c|c|c|c|}
\hline Years & $\begin{array}{c}\text { RD } \\
\text { HEPC } \\
\mathrm{N}\end{array}$ & $\begin{array}{c}\text { RD } \\
\text { HEPC } \\
\%\end{array}$ & $\begin{array}{c}\text { RD } \\
\text { ACUHOI } \\
\mathrm{N}\end{array}$ & $\begin{array}{c}\text { RD } \\
\text { ACUHOI } \\
\%\end{array}$ & $\begin{array}{c}\text { RD } \\
\text { Total } \\
\mathrm{N}\end{array}$ & $\begin{array}{c}\mathrm{RD} \\
\text { Total } \\
\%\end{array}$ \\
\hline 1 Year or Less & 17 & 34.0 & 4 & 19.0 & 21 & 29.6 \\
\hline 2 Years & 15 & 30.0 & 5 & 23.8 & 20 & 28.2 \\
\hline 3 Years & 6 & 12.0 & 6 & 28.6 & 12 & 16.9 \\
\hline 4 Years & 3 & 6.0 & 0 & 0.0 & 3 & 4.2 \\
\hline 5 Years or More & 0 & 0.0 & 1 & 4.8 & 1 & 1.4 \\
\hline Unsure & 9 & 18.0 & 5 & 23.8 & 14 & 19.7 \\
\hline Total Answered & 50 & & 21 & & 71 & \\
\hline Skipped Question & 17 & & 14 & & 31 & \\
\hline
\end{tabular}

Table 83 reflects that the majority of HEPC administrators indicated that resident directors were "Highly Likely" to continue at their current institution "1 Year or Less" (57.9\%) or "Two Years" (57.1\%). Table 84 reflects that the majority of ACUHO-I administrators felt that resident directors were "Highly Likely" to continue at their current institution "1 Year or Less" (60\%), "2 Years" (68.8\%), or "Three Years" (56.3\%). Tables 83 and 84 reflect that the HEPC and ACUHO-I survey results were not similar in that the majority of HEPC administrators 
felt it was "Highly Likely" that resident directors would remain at their institution one to two years while the majority of ACUHO-I administrators felt that it was "Highly Likely" that the resident directors would remain at their current institution one to three years.

Table 83

HEPC Administrators' Likelihood Rating of RDs to Remain at Current Institution

\begin{tabular}{lcccccc}
\hline Years & $\begin{array}{c}\text { Highly } \\
\text { Likely } \\
\%(\mathrm{~N})\end{array}$ & $\begin{array}{c}\text { Somewhat } \\
\text { Likely } \\
\%(\mathrm{~N})\end{array}$ & $\begin{array}{c}\text { Neutral } \\
\text { Unsure } \\
\%(\mathrm{~N})\end{array}$ & $\begin{array}{c}\text { Somewhat } \\
\text { Unlikely } \\
\%(\mathrm{~N})\end{array}$ & $\begin{array}{c}\text { Highly } \\
\text { Unlikely } \\
\%(\mathrm{~N})\end{array}$ & $\begin{array}{c}\text { Response } \\
\text { Count }\end{array}$ \\
\hline 1 Year or Less & $57.9(11)$ & $0.0(0)$ & $0.0(0)$ & $5(26.3)$ & $15.8(3)$ & 19 \\
& & & & & & \\
2 Years & $57.1(12)$ & $19.0(4)$ & $4.8(1)$ & $4(19.0)$ & $0.0(0)$ & 21 \\
3 Years & $40.0(8)$ & $55.0(11)$ & $5.0(1)$ & $0(0.0)$ & $0.0(0)$ & 20 \\
4 Years & $10.0(2)$ & $65.0(13)$ & $15.0(3)$ & $2(10.0)$ & $0.0(0)$ & 20 \\
5 Years or More & $5.0(1)$ & $25.0(5)$ & $15.0(3)$ & $35.0(7)$ & $20.0(4)$ & 20 \\
Skipped Question & & & & & & 5 \\
\end{tabular}

Table 84

ACUHO-I Administrators' Likelihood Rating of RDs to Remain at Current Institution

\begin{tabular}{lcccccc}
\hline Years & $\begin{array}{c}\text { Highly } \\
\text { Likely } \\
\%(\mathrm{~N})\end{array}$ & $\begin{array}{c}\text { Somewhat } \\
\text { Likely } \\
\%(\mathrm{~N})\end{array}$ & $\begin{array}{c}\text { Neutral } \\
\text { Unsure } \\
\%(\mathrm{~N})\end{array}$ & $\begin{array}{c}\text { Somewhat } \\
\text { Unlikely } \\
\%(\mathrm{~N})\end{array}$ & $\begin{array}{c}\text { Highly } \\
\text { Unlikely } \\
\%(\mathrm{~N})\end{array}$ & $\begin{array}{c}\text { Response } \\
\text { Count }\end{array}$ \\
\hline 1 Year or less & $60.0(9)$ & $0.0(0)$ & $0.0(0)$ & $26.7(4)$ & $13.3(2)$ & 15 \\
& & & & & & \\
2 Years & $68.8(11)$ & $12.5(2)$ & $6.3(1)$ & $12.5(2)$ & $0.0(0)$ & 16 \\
3 Years & $56.3(9)$ & $31.3(5)$ & $6.3(1)$ & $6.3(1)$ & $0.0(0)$ & 16 \\
4 Years & $22.2(4)$ & $44.4(8)$ & $16.7(3)$ & $11.1(2)$ & $5.6(1)$ & 18 \\
5 Years or More & $6.7(1)$ & $20.0(3)$ & $6.7(1)$ & $40.0(6)$ & $26.7(4)$ & 15 \\
Skipped Question & & & & & & 2 \\
\hline
\end{tabular}


Table 85 reflects that the majority of resident directors were "Highly Unlikely" to continue as a resident director at another institution with $39.1 \%(n=34)$ rating this category. The HEPC and ACUHO-I survey results were similar in that the majority of respondents indicated that they were "Highly Unlikely" to continue as a resident director at another institution.

However, it should be noted that ACUHO-I resident directors' response had more variance in the response categories.

Table 85

Likeliness of Resident Directors to Continue as RD at Another Institution

\begin{tabular}{lcccccc}
\hline Likeliness & RD & RD & RD & RD & RD & RD \\
& HEPC & HEPC & ACUHOI & ACUHOI & Total & $\begin{array}{c}\text { Total } \\
\%\end{array}$ \\
& N & $\%$ & N & $\%$ & N & $\% .1$ \\
Highly Likely & 3 & 5.1 & 4 & 14.3 & 7 & 8.1 \\
Somewhat Likely & 4 & 6.8 & 5 & 17.9 & 9 & 10.3 \\
Neutral or Unsure & 13 & 22.0 & 6 & 21.4 & 19 & 21.8 \\
Somewhat Unlikely & 12 & 20.3 & 6 & 21.4 & 18 & 20.7 \\
Highly Unlikely & 27 & 45.8 & 7 & 25.0 & 34 & 39.1 \\
Total Answered & 59 & & 28 & & 87 & \\
Skipped Question & 8 & & 7 & & 15 & \\
\hline
\end{tabular}

Table 86 reflects that the majority of HEPC resident directors were "Highly Likely" to leave the resident director position for "Another Position" with $76.3 \%(n=45)$ rating this category. Table 87 reflects that the majority of ACUHO-I resident directors were "Highly Likely" to leave the resident director position for "Another Position" with $53.6 \%(\mathrm{n}=15)$ rating this category. Tables 87 and 88 reflect that the HEPC and ACUHO-I survey results were similar 
in the majority of respondents indicated that they were "Highly Likely" to leave the resident director position for "Another Position."

Table 86

HEPC Resident Directors' Rating of Reasons Likely to Leave RD Position

\begin{tabular}{|c|c|c|c|c|c|c|}
\hline Reason & $\begin{array}{l}\text { Highly } \\
\text { Likely } \\
\%(\mathrm{~N})\end{array}$ & $\begin{array}{c}\text { Somewhat } \\
\text { Likely } \\
\%(\mathrm{~N}) \\
\end{array}$ & $\begin{array}{c}\text { Neutral } \\
\text { Unsure } \\
\%(\mathrm{~N}) \\
\end{array}$ & $\begin{array}{c}\text { Somewhat } \\
\text { Unlikely } \\
\%(\mathrm{~N})\end{array}$ & $\begin{array}{c}\text { Highly } \\
\text { Unlikely } \\
\%(\mathrm{~N}) \\
\end{array}$ & $\begin{array}{l}\text { Response } \\
\text { Count }\end{array}$ \\
\hline $\begin{array}{l}\text { Does Not } \\
\text { Want to Live-in }\end{array}$ & $43.9(25)$ & $24.6(14)$ & $14.0(8)$ & $7.0(4)$ & $10.5(6)$ & 57 \\
\hline Feel Unappreciated & $15.5(9)$ & $22(37.9)$ & $13.8(8)$ & $17.2(10)$ & $15.5(9)$ & 58 \\
\hline Another Position & $76.3(45)$ & $20.3(12)$ & $3.4(2)$ & $0.0(0)$ & $0.0(0)$ & 59 \\
\hline $\begin{array}{l}\text { Pursuit of Educational } \\
\text { Opportunities }\end{array}$ & $35.6(21)$ & $23.7(14)$ & $15.3(9)$ & $16.9(10)$ & $8.5(5)$ & 59 \\
\hline Job Burnout & $35.1(20)$ & $33.3(19)$ & $10.5(6)$ & $12.3(7)$ & $8.8(5)$ & 57 \\
\hline Inadequate Benefits & $7.0(4)$ & $10.5(6)$ & $21.1(12)$ & $31.6(18)$ & $29.8(17)$ & 57 \\
\hline Inadequate Salary & $12.3(7)$ & $26.3(15)$ & $15.8(9)$ & $26.3(15)$ & $19.3(11)$ & 57 \\
\hline $\begin{array}{l}\text { Does Not Get Along } \\
\text { with Administration }\end{array}$ & $7.0(4)$ & $21.1(12)$ & $15.8(9)$ & $22.8(13)$ & $33.3(19)$ & 57 \\
\hline Skipped Question & & & & & & 8 \\
\hline
\end{tabular}

Table 87

ACUHO-I Resident Directors' Rating of Reasons Likely to Leave RD Position

\begin{tabular}{lcccccc}
\hline Reason & $\begin{array}{c}\text { Highly } \\
\text { Likely } \\
\%(\mathrm{~N})\end{array}$ & $\begin{array}{c}\text { Somewhat } \\
\text { Likely } \\
\%(\mathrm{~N})\end{array}$ & $\begin{array}{c}\text { Neutral } \\
\text { Unsure } \\
\%(\mathrm{~N})\end{array}$ & $\begin{array}{c}\text { Somewhat } \\
\text { Unlikely } \\
\%(\mathrm{~N})\end{array}$ & $\begin{array}{c}\text { Highly } \\
\text { Unlikely } \\
\%(\mathrm{~N})\end{array}$ & $\begin{array}{c}\text { Response } \\
\text { Count }\end{array}$ \\
\hline Does Not & $7.1(2)$ & $39.1(11)$ & $17.9(5)$ & $17.9(5)$ & $17.9(5)$ & 28 \\
Want to Live-in & & & & & & (continued)
\end{tabular}




\begin{tabular}{lcccccc}
\hline Reason & $\begin{array}{c}\text { Highly } \\
\text { Likely } \\
\%(\mathrm{~N})\end{array}$ & $\begin{array}{c}\text { Somewhat } \\
\text { Likely } \\
\%(\mathrm{~N})\end{array}$ & $\begin{array}{c}\text { Neutral } \\
\text { Unsure } \\
\%(\mathrm{~N})\end{array}$ & $\begin{array}{c}\text { Somewhat } \\
\text { Unlikely } \\
\%(\mathrm{~N})\end{array}$ & $\begin{array}{c}\text { Highly } \\
\text { Unlikely } \\
\%(\mathrm{~N})\end{array}$ & $\begin{array}{c}\text { Response } \\
\text { Count }\end{array}$ \\
\hline Feel Unappreciated & $0.0(0)$ & $10.7(3)$ & $10.7(3)$ & $32.1(9)$ & $46.4(13)$ & 28 \\
Another Position & $53.6(15)$ & $35.7(10)$ & $7.1(2)$ & $0.0(0)$ & $3.6(1)$ & 28 \\
$\begin{array}{l}\text { Pursuit of } \\
\begin{array}{l}\text { Educational } \\
\text { Opportunities }\end{array}\end{array}$ & $21.4(6)$ & $25.0(7)$ & $17.9(5)$ & $32.1(9)$ & $3.6(1)$ & 28 \\
Job Burnout & $0.0(0)$ & $42.9(12)$ & $14.3(4)$ & $32.1(9)$ & $10.7(3)$ & 28 \\
Inadequate Benefits & $7.1(2)$ & $14.3(4)$ & $14.3(4)$ & $35.7(10)$ & $28.6(8)$ & 28 \\
Inadequate Salary & $10.7(3)$ & $17.9(5)$ & $17.9(5)$ & $35.7(10)$ & $17.9(5)$ & 28 \\
$\begin{array}{l}\text { Does Not Get Along } \\
\text { with Administration }\end{array}$ & $3.6(1)$ & $0.0(0)$ & $14.3(4)$ & $25.0(7)$ & $57.1(16)$ & 28 \\
Skipped Question & & & & & & 7 \\
\hline
\end{tabular}

Table 88 reflects that the majority of HEPC administrators felt it was "Very Common" for resident directors to leave their position for "Another Position" with $90.5 \%(\mathrm{n}=19)$ rating this category. Table 89 reflects that the majority of ACUHO-I administrators felt it was "Very Common" for resident directors to leave their position for "Another Position" with 84.2\% ( $\mathrm{n}=16)$ rating this category. The HEPC and ACUHO-I survey results were similar in that tables 88 and 89 reflect that that the majority of respondents felt it was "Very Common" for resident directors to leave their position for "Another Position." 
Table 88

HEPC Administrators' Rating of Common Reasons RD Likely to Leave

\begin{tabular}{|c|c|c|c|c|c|c|}
\hline Reason & $\begin{array}{c}\text { Very } \\
\text { Common } \\
\%(\mathrm{~N})\end{array}$ & $\begin{array}{c}\text { Somewhat } \\
\text { Common } \\
\%(\mathrm{~N})\end{array}$ & $\begin{array}{l}\text { Neutral } \\
\%(\mathrm{~N})\end{array}$ & $\begin{array}{c}\text { Somewhat } \\
\text { Uncommon } \\
\%(\mathrm{~N})\end{array}$ & $\begin{array}{c}\text { Very } \\
\text { Uncommon } \\
\%(\mathrm{~N})\end{array}$ & $\begin{array}{c}\text { Response } \\
\text { Count }\end{array}$ \\
\hline $\begin{array}{l}\text { Does Not } \\
\text { Want to Live-in }\end{array}$ & $38.1(8)$ & $47.6(10)$ & $9.5(2)$ & $4.8(1)$ & $0.0(0)$ & 21 \\
\hline Feel Unappreciated & $4.8(1)$ & $23.8(5)$ & $23.8(5)$ & $33.3(7)$ & $14.3(3)$ & 21 \\
\hline Another Position & $90.5(19)$ & $9.5(2)$ & $0.0(0)$ & $0.0(0)$ & $0.0(0)$ & 21 \\
\hline $\begin{array}{l}\text { Pursuit of } \\
\text { Educational } \\
\text { Opportunities }\end{array}$ & $33.3(7)$ & $38.1(8)$ & $9.5(2)$ & $14.3(3)$ & $4.8(1)$ & 21 \\
\hline Job Burnout & $14.3(3)$ & $38.1(8)$ & $38.1(8)$ & $9.5(2)$ & $0.0(0)$ & 21 \\
\hline Inadequate Benefits & $0.0(0)$ & $9.5(2)$ & $9.5(2)$ & $38.1(8)$ & $42.9(9)$ & 21 \\
\hline Inadequate Salary & $0.0(0)$ & $9.5(2)$ & $33.3(7)$ & $28.6(6)$ & $28.6(6)$ & 21 \\
\hline $\begin{array}{l}\text { Does Not Get Along } \\
\text { with Administration }\end{array}$ & $4.8(1)$ & $9.5(2)$ & $14.3(3)$ & $33.3(7)$ & $38.1(8)$ & 21 \\
\hline Skipped Question & & & & & & 5 \\
\hline
\end{tabular}

Table 89

ACUHO-I Administrators' Rating of Common Reasons RD Likely to Leave

\begin{tabular}{lcccccc}
\hline Reason & $\begin{array}{c}\text { Very } \\
\text { Common } \\
\%(\mathrm{~N})\end{array}$ & $\begin{array}{c}\text { Somewhat } \\
\text { Common } \\
\%(\mathrm{~N})\end{array}$ & $\begin{array}{c}\text { Neutral } \\
\%(\mathrm{~N})\end{array}$ & $\begin{array}{c}\text { Somewhat } \\
\text { Uncommon } \\
\%(\mathrm{~N})\end{array}$ & $\begin{array}{c}\text { Very } \\
\text { Uncommon } \\
\%(\mathrm{~N})\end{array}$ & $\begin{array}{c}\text { Response } \\
\text { Count }\end{array}$ \\
\hline $\begin{array}{l}\text { Does Not } \\
\text { Want to Live-in }\end{array}$ & $27.8(5)$ & $50.0(9)$ & $11.1(2)$ & $11.1(2)$ & $0.0(0)$ & 18 \\
Feel Unappreciated & $0.0(0)$ & $5.6(1)$ & $27.8(5)$ & $27.8(5)$ & $38.9(7)$ & 18 \\
& & & & & & (continued)
\end{tabular}




\begin{tabular}{|c|c|c|c|c|c|c|}
\hline Reason & $\begin{array}{c}\text { Very } \\
\text { Common } \\
\%(\mathrm{~N})\end{array}$ & $\begin{array}{l}\text { Somewhat } \\
\text { Common } \\
\%(\mathrm{~N})\end{array}$ & $\begin{array}{c}\text { Neutral } \\
\%(\mathrm{~N})\end{array}$ & $\begin{array}{c}\text { Somewhat } \\
\text { Uncommon } \\
\%(\mathrm{~N})\end{array}$ & $\begin{array}{c}\text { Very } \\
\text { Uncommon } \\
\%(\mathrm{~N})\end{array}$ & $\begin{array}{c}\text { Response } \\
\text { Count }\end{array}$ \\
\hline Another Position & $84.2(16)$ & $5.3(1)$ & $5.3(1)$ & $0.0(0)$ & $5.3(1)$ & 19 \\
\hline $\begin{array}{l}\text { Pursuit of Educational } \\
\text { Opportunities }\end{array}$ & $10.5(2)$ & $36.8(7)$ & $10.5(2)$ & $31.6(6)$ & $10.5(2)$ & 19 \\
\hline Job Burnout & $5.6(1)$ & $44.4(8)$ & $11.1(2)$ & $22.2(4)$ & $16.7(3)$ & 18 \\
\hline Inadequate Benefits & $0.0(0)$ & $11.1(2)$ & $5.6(1)$ & $27.8(5)$ & $55.6(10)$ & 18 \\
\hline Inadequate Salary & $5.9(1)$ & $5.9(1)$ & $11.8(2)$ & $29.4(5)$ & $47.1(8)$ & 17 \\
\hline $\begin{array}{l}\text { Does Not Get Along } \\
\text { with Administration }\end{array}$ & $0.0(0)$ & $5.6(1)$ & $11.1(2)$ & $16.7(3)$ & $66.7(12)$ & 18 \\
\hline Skipped Question & & & & & & 1 \\
\hline
\end{tabular}

Table 90 reflects that the majority of resident directors felt "Respected" by department administration with $50.6 \%(\mathrm{n}=44)$ rating this category. The HEPC and ACUHO-I survey results were similar in that the majority of respondents indicated that they felt "Respected" by department administration.

Table 90

Degree to Which Resident Directors Felt Respected by Department Administration

\begin{tabular}{lcccccc}
\hline Level of Respect & RD & RD & RD & RD & RD & RD \\
& HEPC & HEPC & ACUHOI & ACUHOI & Total & Total \\
& N & $\%$ & N & $\%$ & N & $\%$ \\
\hline Highly Respected & 10 & 16.9 & 12 & 42.9 & 22 & 25.3 \\
Respected & 29 & 49.2 & 15 & 53.6 & 44 & 50.6 \\
& & & & & & \\
\end{tabular}




\begin{tabular}{lcccccc}
\hline Level of Respect & RD & RD & RD & RD & RD & RD \\
& HEPC & HEPC & ACUHOI & ACUHOI & Total & Total \\
& N & $\%$ & N & $\%$ & N & $\%$ \\
\hline Somewhat Respected & 13 & 22.0 & 0 & 0.0 & 13 & 14.9 \\
Rarely Respected & 7 & 11.9 & 1 & 3.6 & 8 & 9.2 \\
Never Respected & 0 & 0.0 & 0 & 0.0 & 0 & 0.0 \\
Total Answered & 59 & & 28 & & 87 & \\
Skipped Question & 8 & & 7 & & 15 & \\
\hline
\end{tabular}

Table 91 reflects that the majority of administrators felt resident directors were "Highly Respected" by department administration with $50.0 \%(\mathrm{n}=20)$ rating this category. The HEPC and ACUHO-I survey results were not similar in that the majority of the HEPC administrators felt that resident directors were "Respected" while the majority of ACUHO-I administrators felt that resident directors were "Highly Respected."

Table 91

Degree to Which Administrators Felt RDs Respected by Department Administration

\begin{tabular}{lcccccc}
\hline Level of Respect & $\begin{array}{c}\text { Admin. } \\
\text { HEPC }\end{array}$ & $\begin{array}{c}\text { Admin. } \\
\text { HEPC } \\
\%\end{array}$ & $\begin{array}{c}\text { Admin. } \\
\text { ACUHOI }\end{array}$ & $\begin{array}{c}\text { Admin. } \\
\text { ACUHOI } \\
\%\end{array}$ & $\begin{array}{c}\text { Admin. } \\
\text { Total } \\
\text { N }\end{array}$ & $\begin{array}{c}\text { Admin. } \\
\text { Total } \\
\%\end{array}$ \\
\hline Highly Respected & 8 & 38.1 & 12 & 63.2 & 20 & 50.0 \\
Respected & 10 & 47.6 & 6 & 31.6 & 16 & 40.0 \\
Somewhat Respected & 3 & 14.3 & 0 & 0.0 & 3 & 7.5 \\
Rarely Respected & 0 & 0.0 & 1 & 5.3 & 1 & 2.5 \\
Never Respected & 0 & 0.0 & 0 & 0.0 & 0 & 0.0 \\
& & & & & & (continued)
\end{tabular}




\begin{tabular}{|c|c|c|c|c|c|c|}
\hline Level of Respect & $\begin{array}{c}\text { Admin. } \\
\text { HEPC } \\
\text { N }\end{array}$ & $\begin{array}{c}\text { Admin. } \\
\text { HEPC } \\
\%\end{array}$ & $\begin{array}{l}\text { Admin. } \\
\text { ACUHOI } \\
\mathrm{N}\end{array}$ & $\begin{array}{c}\text { Admin. } \\
\text { ACUHOI } \\
\%\end{array}$ & $\begin{array}{c}\text { Admin. } \\
\text { Total } \\
\text { N }\end{array}$ & $\begin{array}{c}\text { Admin. } \\
\text { Total } \\
\%\end{array}$ \\
\hline Total Answered & 21 & & 19 & & 40 & \\
\hline Skipped Question & 5 & & 1 & & 6 & \\
\hline
\end{tabular}

Table 92 reflects that the majority of resident directors felt "Somewhat Respected" by university administration with $43.7 \%(n=38)$ rating this category. The HEPC and ACUHO-I survey results were not similar in that the majority of the HEPC resident directors felt "Somewhat Respected" while the majority of the ACUHO-I resident directors felt "Respected." Table 92

Degree to Which Resident Directors Felt Respected by University Administration

\begin{tabular}{|c|c|c|c|c|c|c|}
\hline Level of Respect & $\begin{array}{c}\text { RD } \\
\text { HEPC } \\
\mathrm{N}\end{array}$ & $\begin{array}{c}\text { RD } \\
\text { HEPC } \\
\%\end{array}$ & $\begin{array}{c}\text { RD } \\
\text { ACUHOI } \\
\mathrm{N}\end{array}$ & $\begin{array}{c}\text { RD } \\
\text { ACUHOI } \\
\%\end{array}$ & $\begin{array}{c}\text { RD } \\
\text { Total } \\
\mathrm{N}\end{array}$ & $\begin{array}{c}\text { RD } \\
\text { Total } \\
\%\end{array}$ \\
\hline Highly Respected & 3 & 5.1 & 7 & 25.0 & 10 & 11.5 \\
\hline Respected & 15 & 25.4 & 11 & 39.3 & 26 & 29.9 \\
\hline Somewhat Respected & 28 & 47.5 & 10 & 35.7 & 38 & 43.7 \\
\hline Rarely Respected & 11 & 18.6 & 0 & 0.0 & 11 & 12.6 \\
\hline Never Respected & 2 & 3.4 & 0 & 0.0 & 2 & 2.3 \\
\hline Total Answered & 59 & & 28 & & 87 & \\
\hline Skipped Question & 8 & & 7 & & 15 & \\
\hline
\end{tabular}

Table 93 reflects that the majority of administrators felt resident directors were "Respected" by university administration with $45.0 \%(\mathrm{n}=18)$ rating this category. The HEPC 
and ACUHO-I survey results were similar in that the majority of respondents indicated that they felt resident directors were "Respected" by university administration.

Table 93

Degree to Which Administrators Felt Resident Directors Respected by University Administration

\begin{tabular}{|c|c|c|c|c|c|c|}
\hline Level of Respect & $\begin{array}{c}\text { Admin. } \\
\text { HEPC } \\
\mathrm{N}\end{array}$ & $\begin{array}{c}\text { Admin. } \\
\text { HEPC } \\
\%\end{array}$ & $\begin{array}{c}\text { Admin. } \\
\text { ACUHOI } \\
\mathrm{N}\end{array}$ & $\begin{array}{c}\text { Admin. } \\
\text { ACUHOI } \\
\%\end{array}$ & $\begin{array}{c}\text { Admin. } \\
\text { Total } \\
\mathrm{N}\end{array}$ & $\begin{array}{c}\text { Admin. } \\
\text { Total } \\
\%\end{array}$ \\
\hline Highly Respected & 1 & 4.8 & 6 & 31.6 & 7 & 17.5 \\
\hline Respected & 10 & 47.6 & 8 & 42.1 & 18 & 45.0 \\
\hline Somewhat Respected & 8 & 38.1 & 5 & 26.3 & 13 & 32.5 \\
\hline Rarely Respected & 2 & 9.5 & 0 & 0.0 & 2 & 5.0 \\
\hline Never Respected & 0 & 0.0 & 0 & 0.0 & 0 & 0.0 \\
\hline Total Answered & 21 & & 19 & & 40 & \\
\hline Skipped Question & 5 & & 1 & & 6 & \\
\hline
\end{tabular}

Table 94 reflects that the majority of resident directors felt "Somewhat Valued" as a staff member with $40.2 \%(n=35)$ rating this category. The HEPC and ACUHO-I survey results were not similar in that the majority of the HEPC resident directors felt "Somewhat Valued" while the majority of the ACUHO-I resident directors felt "Very Valued."

Table 94

Degree to Which Resident Directors Felt Valued as a Staff Member

\begin{tabular}{lcccccc}
\hline Level of Value & RD & RD & RD & RD & RD & RD \\
& HEPC & HEPC & ACUHOI & ACUHOI \\
& N & $\%$ & Notal & Total \\
Extremely Valued & 6 & 10.2 & 9 & 32.1 & 15 & 17.2 \\
\hline & & & & & & (continued)
\end{tabular}




\begin{tabular}{lcccccc}
\hline Level of Respect & $\begin{array}{c}\text { Admin. } \\
\text { HEPC } \\
\text { N }\end{array}$ & $\begin{array}{c}\text { Admin. } \\
\text { HEPC } \\
\%\end{array}$ & $\begin{array}{c}\text { Admin. } \\
\text { ACUHOI } \\
\text { N }\end{array}$ & $\begin{array}{c}\text { Admin. } \\
\text { ACUHOI } \\
\%\end{array}$ & $\begin{array}{c}\text { Admin. } \\
\text { Total } \\
\text { N }\end{array}$ & $\begin{array}{c}\text { Admin. } \\
\text { Total } \\
\%\end{array}$ \\
\hline Very Valued & 17 & 28.8 & 12 & 42.9 & 29 & 33.3 \\
Somewhat Valued & 28 & 47.5 & 7 & 25.0 & 35 & 40.2 \\
Rarely Valued & 8 & 13.6 & 0 & 0.0 & 8 & 9.2 \\
Never Valued & 0 & 0.0 & 0 & 0.0 & 0 & 0.0 \\
Total Answered & 59 & & 28 & & 87 & \\
Skipped Question & 8 & & 7 & & 15 & \\
\hline
\end{tabular}

Table 95 reflects that the majority of administrators felt resident directors were "Extremely Valued" as a staff member with $47.4 \%(\mathrm{n}=18)$ rating this category. The HEPC and ACUHO-I results were not similar in that the majority of the HEPC administrators felt resident directors were "Extremely Valued" and "Very Valued" while the majority of the ACUHO-I administrators felt resident directors were "Extremely Valued."

Table 95

Degree to Which Administrators Felt Resident Directors Valued as a Staff Member

\begin{tabular}{lcccccc}
\hline Level of Value & $\begin{array}{c}\text { Admin. } \\
\text { HEPC } \\
\end{array}$ & $\begin{array}{c}\text { Admin. } \\
\text { HEPC }\end{array}$ & $\begin{array}{c}\text { Admin. } \\
\text { ACUHOI }\end{array}$ & $\begin{array}{c}\text { Admin. } \\
\text { ACUHOI }\end{array}$ & $\begin{array}{c}\text { Admin. } \\
\text { Total } \\
\text { N }\end{array}$ & $\begin{array}{c}\text { Admin. } \\
\text { Total } \\
\%\end{array}$ \\
\hline Extremely Valued & 9 & 42.9 & 9 & 52.9 & 18 & 47.4 \\
Very Valued & 9 & 42.9 & 6 & 35.3 & 15 & 39.5 \\
Somewhat Valued & 2 & 9.5 & 2 & 11.8 & 4 & 10.5 \\
Rarely Valued & 1 & 4.8 & 0 & 0.0 & 1 & 2.6 \\
Never Valued & 0 & 0.0 & 0 & 0.0 & 0 & 0.0 \\
& & & & & & (continued)
\end{tabular}




\begin{tabular}{|c|c|c|c|c|c|c|}
\hline Level of Value & $\begin{array}{c}\text { Admin. } \\
\text { HEPC } \\
\mathrm{N}\end{array}$ & $\begin{array}{c}\text { Admin. } \\
\text { HEPC } \\
\%\end{array}$ & $\begin{array}{l}\text { Admin. } \\
\text { ACUHOI } \\
\mathrm{N}\end{array}$ & $\begin{array}{c}\text { Admin. } \\
\text { ACUHOI } \\
\%\end{array}$ & $\begin{array}{c}\text { Admin. } \\
\text { Total } \\
\text { N }\end{array}$ & $\begin{array}{c}\text { Admin. } \\
\text { Total } \\
\%\end{array}$ \\
\hline Total Answered & 21 & & 17 & & 38 & \\
\hline Skipped Question & 5 & & 3 & & 8 & \\
\hline
\end{tabular}

Table 96 reflects that the majority of resident directors felt they were provided with performance feedback "Occasionally" with $48.3 \%(\mathrm{n}=42)$ rating this category. The HEPC and ACUHO-I survey results were not similar in that the majority of the HEPC resident directors felt they were provided with performance feedback "Occasionally" while the majority of the ACUHO-I resident directors felt they were provided with performance feedback "Often."

Table 96

Frequency in Which Resident Directors Provided Performance Feedback

\begin{tabular}{lcccccc}
\hline Frequency & RD & RD & RD & RD & RD & RD \\
& HEPC & HEPC & ACUHOI & ACUHOI & Total & Total \\
& N & $\%$ & N & $\%$ & N \\
\hline Very Often & 2 & 3.4 & 5 & 17.9 & 7 & 8.0 \\
Often & 16 & 27.1 & 12 & 42.9 & 28 & 32.2 \\
Occasionally & 34 & 57.6 & 8 & 28.6 & 42 & 48.3 \\
Rarely & 6 & 10.2 & 1 & 3.6 & 7 & 8.0 \\
Never & 1 & 1.7 & 2 & 7.1 & 3 & 3.4 \\
Total Answered & 59 & & 28 & & 87 & \\
Skipped Question & 8 & & 7 & & 15 & \\
\hline
\end{tabular}


Table 97 reflects that the majority of administrators felt they provided resident directors performance feedback "Often" with 53.8\% $(\mathrm{n}=21)$ rating this category. The HEPC and ACUHO-I survey results were similar in that the majority of respondents indicated that they felt they provided performance feedback to resident directors "Often."

Table 97

Frequency in Which Administrators Provided Resident Directors with Performance Feedback

\begin{tabular}{|c|c|c|c|c|c|c|}
\hline Frequency & $\begin{array}{c}\text { Admin. } \\
\text { HEPC } \\
\mathrm{N}\end{array}$ & $\begin{array}{c}\text { Admin. } \\
\text { HEPC } \\
\%\end{array}$ & $\begin{array}{c}\text { Admin. } \\
\text { ACUHOI } \\
\mathrm{N}\end{array}$ & $\begin{array}{c}\text { Admin. } \\
\text { ACUHOI } \\
\%\end{array}$ & $\begin{array}{c}\text { Admin. } \\
\text { Total } \\
\text { N }\end{array}$ & $\begin{array}{c}\text { Admin. } \\
\text { Total } \\
\% \\
\end{array}$ \\
\hline Very Often & 5 & 23.8 & 5 & 27.8 & 10 & 25.7 \\
\hline Often & 11 & 52.4 & 10 & 55.6 & 21 & 53.8 \\
\hline Occasionally & 5 & 23.8 & 3 & 16.7 & 8 & 20.5 \\
\hline Rarely & 0 & 0.0 & 0 & 0.0 & 0 & 0.0 \\
\hline Never & 0 & 0.0 & 0 & 0.0 & 0 & 0.0 \\
\hline Total Answered & 21 & & 18 & & 39 & \\
\hline Skipped Question & 5 & & 2 & & 7 & \\
\hline
\end{tabular}

Table 98 reflects that the majority of resident directors felt they were able to operate autonomously "Very Often" with 64.0\% $(\mathrm{n}=55)$ rating this category. The HEPC and ACUHO-I survey results were similar in that the majority of respondents indicated that they were able to operate autonomously "Very Often." However, it should be noted that ACUHO-I resident directors felt that they were able to operate autonomously at a higher percentage rate $(16.4 \%$ higher) than their HEPC peers. 
Table 98

Frequency in Which Resident Directors Able to Operate Autonomously

\begin{tabular}{|c|c|c|c|c|c|c|}
\hline Frequency & $\begin{array}{c}\mathrm{RD} \\
\mathrm{HEPC} \\
\mathrm{N}\end{array}$ & $\begin{array}{c}\text { RD } \\
\text { HEPC } \\
\% \\
\end{array}$ & $\begin{array}{c}\mathrm{RD} \\
\text { ACUHOI } \\
\mathrm{N}\end{array}$ & $\begin{array}{c}\text { RD } \\
\text { ACUHOI } \\
\%\end{array}$ & $\begin{array}{c}\text { RD } \\
\text { Total } \\
\mathrm{N}\end{array}$ & $\begin{array}{c}\mathrm{RD} \\
\text { Total } \\
\% \\
\end{array}$ \\
\hline Very Often & 34 & 58.6 & 21 & 75.0 & 55 & 64.0 \\
\hline Often & 16 & 27.6 & 6 & 21.4 & 22 & 25.6 \\
\hline Occasionally & 6 & 10.3 & 0 & 0.0 & 6 & 7.0 \\
\hline Rarely & 2 & 3.4 & 1 & 3.6 & 3 & 3.4 \\
\hline Never & 0 & 0.0 & 0 & 0.0 & 0 & 0.0 \\
\hline Total Answered & 58 & & 28 & & 86 & \\
\hline Skipped Question & 9 & & 7 & & 16 & \\
\hline
\end{tabular}

Table 99 reflects that the majority of administrators felt they allowed resident directors to operate autonomously "Often" with $42.5 \%(n=17)$ rating this category. The HEPC and ACUHO-I survey results were not similar in that the majority of the HEPC administrators felt they allowed resident directors to operate autonomously "Very Often" while the majority of the ACUHO-I administrators felt they allowed resident directors to operate autonomously "Often."

Table 99

Frequency in Which Administrator Allowed Resident Directors to Operate Autonomously

\begin{tabular}{|c|c|c|c|c|c|c|}
\hline Frequency & $\begin{array}{c}\text { Admin. } \\
\text { HEPC } \\
\mathrm{N}\end{array}$ & $\begin{array}{c}\text { Admin. } \\
\text { HEPC } \\
\%\end{array}$ & $\begin{array}{c}\text { Admin. } \\
\text { ACUHOI } \\
\mathrm{N}\end{array}$ & $\begin{array}{c}\text { Admin. } \\
\text { ACUHOI } \\
\%\end{array}$ & $\begin{array}{c}\text { Admin. } \\
\text { Total } \\
\mathrm{N}\end{array}$ & $\begin{array}{c}\text { Admin. } \\
\text { Total } \\
\%\end{array}$ \\
\hline Very Often & 9 & 42.9 & 7 & 36.8 & 16 & 40.0 \\
\hline Often & 8 & 38.1 & 9 & 47.4 & 17 & 42.5 \\
\hline
\end{tabular}




\begin{tabular}{lcccccc}
\hline Frequency & $\begin{array}{c}\text { Admin. } \\
\text { HEPC }\end{array}$ & $\begin{array}{c}\text { Admin. } \\
\text { HEPC } \\
\text { N }\end{array}$ & $\begin{array}{c}\text { Admin. } \\
\text { ACUHOI }\end{array}$ & $\begin{array}{c}\text { Admin. } \\
\text { ACUHOI } \\
\%\end{array}$ & $\begin{array}{c}\text { Admin. } \\
\text { Total } \\
\text { N }\end{array}$ & $\begin{array}{c}\text { Admin. } \\
\text { Total } \\
\%\end{array}$ \\
\hline Occasionally & 4 & 19.0 & 2 & 10.5 & 6 & 15.0 \\
Rarely & 0 & 0.0 & 1 & 5.3 & 1 & 2.5 \\
Never & 0 & 0.0 & 0 & 0.0 & 0 & 0.0 \\
Total Answered & 21 & & 19 & & 40 & \\
Skipped Question & 5 & & 1 & & 6 & \\
\hline
\end{tabular}

\section{Comparison of Professional Development}

Table 100 reflects that the majority of resident directors felt they were encouraged to develop professionally "Very Often" with $39.1 \%(n=34)$ rating this category. The HEPC and ACUHO-I survey results were not similar in that the majority of the HEPC resident directors felt they were encouraged to develop professionally "Often" while the majority of the ACUHO-I resident directors felt they were encouraged to develop professionally "Very Often."

Table 100

Frequency in Which Resident Directors Encouraged to Develop Professionally

\begin{tabular}{lcccccc}
\hline Frequency & RD & RD & RD & RD & RD & RD \\
& HEPC & HEPC & ACUHOI & ACUHOI & $\begin{array}{c}\text { Total } \\
\text { A }\end{array}$ & $\begin{array}{c}\text { Total } \\
\%\end{array}$ \\
\hline Very Often & 13 & 22.0 & 21 & 75.0 & 34 & 39.1 \\
Often & 22 & 37.3 & 4 & 14.3 & 26 & 29.9 \\
Occasionally & 17 & 28.8 & 3 & 10.7 & 20 & 23.0 \\
Rarely & 7 & 11.9 & 0 & 0.0 & 7 & 8.0 \\
& & & & & & (continued)
\end{tabular}




\begin{tabular}{lcccccc}
\hline Frequency & RD & RD & RD & RD & RD & RD \\
& HEPC & HEPC & ACUHOI & ACUHOI & Total & Total \\
& N & $\%$ & N & $\%$ & N & $\%$ \\
\hline Never & 0 & 0.0 & 0 & 0.0 & 0 & 0.0 \\
Total Answered & 59 & & 28 & & 87 & \\
Skipped & 8 & & 7 & & 15 & \\
Question & & & & & & \\
\end{tabular}

Table 101 reflects that the majority of administrators felt they encouraged resident directors to develop professionally "Very Often" with $80 \%(n=32)$ rating this category. The HEPC and ACUHO-I survey results were similar in that the majority of respondents indicated they encouraged resident directors to develop professionally "Very Often."

Table 101

Frequency in Which Administrators Encouraged Resident Directors to Develop Professionally

\begin{tabular}{|c|c|c|c|c|c|c|}
\hline Frequency & $\begin{array}{c}\text { Admin. } \\
\text { HEPC } \\
\mathrm{N}\end{array}$ & $\begin{array}{c}\text { Admin. } \\
\text { HEPC } \\
\%\end{array}$ & $\begin{array}{c}\text { Admin. } \\
\text { ACUHOI } \\
\mathrm{N}\end{array}$ & $\begin{array}{c}\text { Admin. } \\
\text { ACUHOI } \\
\%\end{array}$ & $\begin{array}{c}\text { Admin. } \\
\text { Total } \\
\text { N }\end{array}$ & $\begin{array}{c}\text { Admin. } \\
\text { Total } \\
\% \\
\end{array}$ \\
\hline Very Often & 17 & 81.0 & 15 & 78.9 & 32 & 80.0 \\
\hline Often & 4 & 19.0 & 4 & 21.1 & 8 & 20.0 \\
\hline Occasionally & 0 & 0.0 & 0 & 0.0 & 0 & 0.0 \\
\hline Rarely & 0 & 0.0 & 0 & 0.0 & 0 & 0.0 \\
\hline Never & 0 & 0.0 & 0 & 0.0 & 0 & 0.0 \\
\hline Total Answered & 21 & & 19 & & 40 & \\
\hline Skipped Question & 5 & & 1 & & 6 & \\
\hline
\end{tabular}


Table 102 reflects that the majority of resident directors participated in professional development "Often" with 38\% (n=33) rating this category. The HEPC and ACUHO-I survey results were not similar in that the majority of the HEPC resident directors participated in professional development "Often" (33.9\%) and "Occasionally" (37.3\%) while the majority of the ACUHO-I resident directors participated in professional development "Very Often" (35.7\%) and “Often” (46.4\%).

Table 102

Frequency in Which Resident Directors Participated in Professional Development

\begin{tabular}{|c|c|c|c|c|c|c|}
\hline Frequency & $\begin{array}{c}\text { RD } \\
\text { HEPC } \\
N\end{array}$ & $\begin{array}{c}\text { RD } \\
\text { HEPC } \\
\%\end{array}$ & $\begin{array}{c}\text { RD } \\
\text { ACUHOI } \\
\mathrm{N}\end{array}$ & $\begin{array}{c}\text { RD } \\
\text { ACUHOI } \\
\%\end{array}$ & $\begin{array}{c}\text { RD } \\
\text { Total } \\
\mathrm{N}\end{array}$ & $\begin{array}{c}\mathrm{RD} \\
\text { Total } \\
\%\end{array}$ \\
\hline Very Often & 12 & 20.3 & 10 & 35.7 & 22 & 25.3 \\
\hline Often & 20 & 33.9 & 13 & 46.4 & 33 & 38.0 \\
\hline Occasionally & 22 & 37.3 & 5 & 17.9 & 27 & 31.0 \\
\hline Rarely & 5 & 8.5 & 0 & 0.0 & 5 & 5.7 \\
\hline Never & 0 & 0.0 & 0 & 0.0 & 0 & 0.0 \\
\hline Total Answered & 59 & & 28 & & 87 & \\
\hline Skipped Question & 8 & & 7 & & 15 & \\
\hline
\end{tabular}

Table 103 reflects that the majority of administrators provide funding for "Tuition for Formal Classes", "Presenting at Conferences", and "Conference Attendance" with over 80\% ratings in each of these categories. The HEPC and ACUHO-I survey results were similar in that "Tuition for Formal Classes", "Presenting at Conferences", and "Conference Attendance" were the most common professional development opportunities that administrators provide funding. 
Table 103

Types of Professional Development Opportunities Administrators Funded

\begin{tabular}{|c|c|c|c|c|c|c|}
\hline Types & $\begin{array}{c}\text { Admin. } \\
\text { HEPC } \\
\mathrm{N}\end{array}$ & $\begin{array}{c}\text { Admin. } \\
\text { HEPC } \\
\%\end{array}$ & $\begin{array}{l}\text { Admin. } \\
\text { ACUHOI } \\
\mathrm{N}\end{array}$ & $\begin{array}{c}\text { Admin. } \\
\text { ACUHOI } \\
\%\end{array}$ & $\begin{array}{l}\text { Admin. } \\
\text { Total } \\
\text { N }\end{array}$ & $\begin{array}{c}\text { Admin. } \\
\text { Total } \\
\%\end{array}$ \\
\hline Conference Attendance & 17 & 85.0 & 15 & 78.9 & 32 & 82.1 \\
\hline $\begin{array}{l}\text { Presenting at } \\
\text { Conferences }\end{array}$ & 17 & 85.0 & 18 & 94.7 & 35 & 89.7 \\
\hline $\begin{array}{l}\text { Membership } \\
\text { Professional } \\
\text { Organizations }\end{array}$ & 13 & 65.0 & 8 & 42.1 & 21 & 53.8 \\
\hline $\begin{array}{l}\text { Subscription to } \\
\text { Scholarly Materials }\end{array}$ & 8 & 40.0 & 6 & 31.6 & 14 & 35.9 \\
\hline $\begin{array}{l}\text { Tuition for Formal } \\
\text { Education }\end{array}$ & 17 & 85.0 & 18 & 94.7 & 35 & 89.7 \\
\hline Other & 6 & & 2 & & 8 & \\
\hline Total Answered & 20 & & 19 & & 39 & \\
\hline Skipped Question & 6 & & 1 & & 7 & \\
\hline
\end{tabular}

Table 104 reflects that the majority of resident directors "Attend Conferences" as their professional development activity with $89.3 \%(n=75)$ rating this category. The HEPC and ACUHO-I survey results were similar in that the majority of respondents indicated that they "Attend Conferences." 
Table 104

Types of Professional Development Opportunities Resident Directors Participated In

\begin{tabular}{|c|c|c|c|c|c|c|}
\hline Types & $\begin{array}{c}\text { RD } \\
\text { HEPC } \\
\mathrm{N}\end{array}$ & $\begin{array}{c}\text { RD } \\
\text { HEPC } \\
\% \\
\end{array}$ & $\begin{array}{c}\text { RD } \\
\text { ACUHOI } \\
\mathrm{N}\end{array}$ & $\begin{array}{c}\text { RD } \\
\text { ACUHOI } \\
\%\end{array}$ & $\begin{array}{c}\text { RD } \\
\text { Total } \\
\mathrm{N}\end{array}$ & $\begin{array}{c}\text { RD } \\
\text { Total } \\
\% \\
\end{array}$ \\
\hline Attend Conferences & 49 & 87.5 & 26 & 92.9 & 75 & 89.3 \\
\hline Present at Conferences & 27 & 48.2 & 21 & 75.0 & 48 & 57.1 \\
\hline $\begin{array}{l}\text { Member Professional } \\
\text { Organizations }\end{array}$ & 40 & 71.4 & 22 & 78.6 & 62 & 73.8 \\
\hline $\begin{array}{l}\text { Read Scholarly } \\
\text { Materials }\end{array}$ & 35 & 62.5 & 22 & 78.6 & 57 & 67.9 \\
\hline Formal Education & 17 & 30.4 & 11 & 39.3 & 28 & 33.3 \\
\hline Total Answered & 56 & & 28 & & 84 & \\
\hline Skipped Question & 11 & & 7 & & 18 & \\
\hline
\end{tabular}

Table 105 reflects that one HEPC resident director did not participate in professional development activities because of "Time Constraints" and because they were "Not Interested." Table 105

Reasons Why Resident Directors Did Not Participate in Professional Development

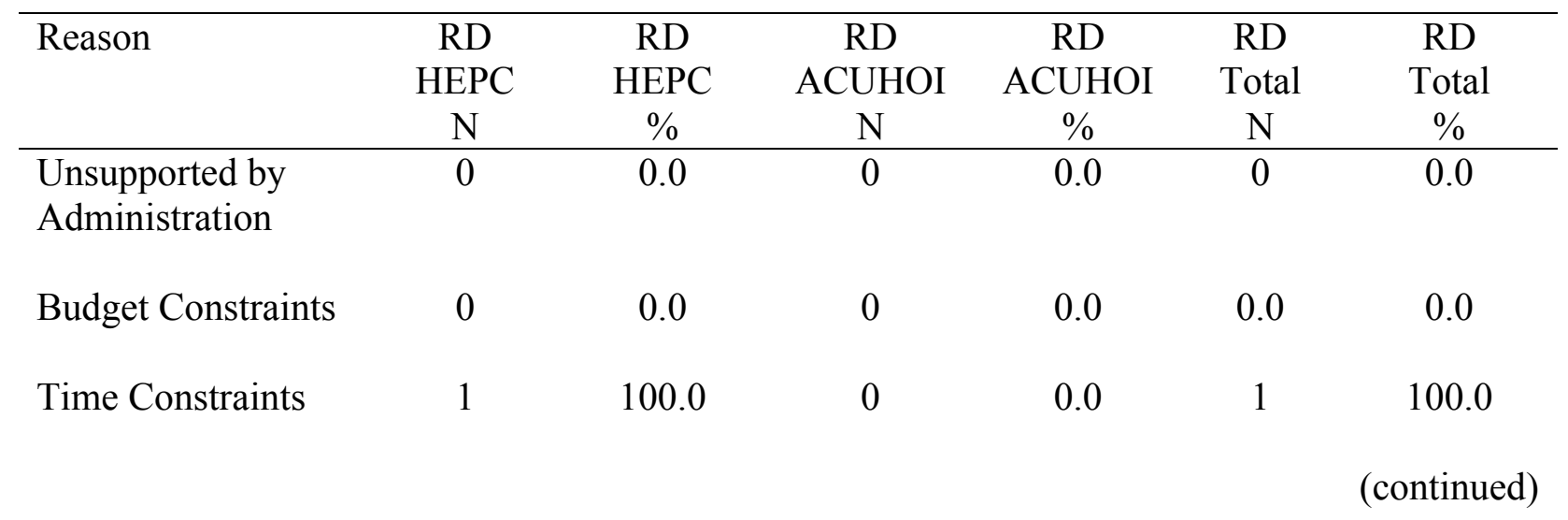




\begin{tabular}{lcccccc}
\hline Reason & RD & RD & RD & RD & RD & RD \\
& HEPC & HEPC & ACUHOI & ACUHOI & Total & $\begin{array}{c}\text { Total } \\
\%\end{array}$ \\
\hline Not Interested & N & $\%$ & N & $\%$ & N & $\%$ \\
Total Answered & 1 & 100.0 & 0 & 0.0 & 1 & 100.0 \\
Skipped Question & 66 & & 0 & & 1 & \\
& & & 35 & & 101 & \\
\hline
\end{tabular}

\section{Comparison of Professional Mentors}

Table 106 reflects that the majority of resident directors have a professional mentor with $62.1 \%(\mathrm{n}=54)$ rating this category. The HEPC and ACUHO-I survey results were similar in that the majority of respondents indicated that they had a professional mentor. However, it should be noted that ACUHO-I resident directors indicated that they had a professional mentor at a higher percentage rate $(13.8 \%$ higher) than their HEPC peers.

Table 106

Resident Directors Who Had Professional Mentors

\begin{tabular}{lcccccc}
\hline Mentor & RD & RD & RD & RD & RD & RD \\
& HEPC & HEPC & ACUHOI & ACUHOI & Total & Total \\
& N & $\%$ & N & $\%$ & N & $\%$ \\
\hline Yes & 34 & 57.6 & 20 & 71.4 & 54 & 62.1 \\
No & 25 & 42.4 & 8 & 28.6 & 33 & 37.9 \\
Total Answered & 59 & & 28 & & 87 & \\
Skipped Question & 8 & & 7 & & 15 & \\
\hline
\end{tabular}

Table 107 reflects that the majority of administrators indicated that they do not have a professional mentor program with $79.5 \%(\mathrm{n}=31)$ rating this category. The HEPC and ACUHO-I 
survey results were similar in that the majority of respondents indicated that they did not have a professional mentor program at their institution.

Table 107

Administrators Who Provided Formal Professional Mentor Programs

\begin{tabular}{lcccccc}
\hline Mentor Program & $\begin{array}{c}\text { Admin. } \\
\text { HEPC } \\
\text { Nes }\end{array}$ & $\begin{array}{c}\text { Admin. } \\
\text { HEPC }\end{array}$ & $\begin{array}{c}\text { Admin. } \\
\text { ACUHOI }\end{array}$ & $\begin{array}{c}\text { Admin. } \\
\text { ACUHOI } \\
\%\end{array}$ & $\begin{array}{c}\text { Admin. } \\
\text { Total } \\
\text { N }\end{array}$ & $\begin{array}{c}\text { Admin. } \\
\text { Total } \\
\%\end{array}$ \\
\hline No & 4 & 19.0 & 4 & 22.2 & 8 & 20.5 \\
Total Answered & 17 & 81.0 & 14 & 77.8 & 31 & 79.5 \\
Skipped Question & 21 & & 18 & & 39 & \\
& 5 & & 2 & & & \\
\end{tabular}

Table 108 reflects that the majority of the professional mentors were classified as either an "External Administrator" or "Friend" by the resident directors with $42.6 \%(n=23)$ rating both of these categories. Two other classifications were noted as "Professor" and "Former Supervisor." The majority of the HEPC resident directors classified their mentors as "Internal Administrator" and "Friend" while the majority of the ACUHO-I resident directors classified their mentors as "External Administrator" and "Friend."

Table 108

Resident Directors' Classification of Professional Mentors

\begin{tabular}{|c|c|c|c|c|c|c|}
\hline Mentor Classification & $\begin{array}{c}\text { RD } \\
\text { HEPC } \\
\text { N }\end{array}$ & $\begin{array}{c}\text { RD } \\
\text { HEPC } \\
\% \\
\end{array}$ & $\begin{array}{c}\text { RD } \\
\text { ACUHOI } \\
\mathrm{N}\end{array}$ & $\begin{array}{c}\mathrm{RD} \\
\text { ACUHOI } \\
\%\end{array}$ & $\begin{array}{c}\text { RD } \\
\text { Total } \\
\mathrm{N}\end{array}$ & $\begin{array}{c}\mathrm{RD} \\
\text { Total } \\
\%\end{array}$ \\
\hline Internal Administrator & 15 & 44.1 & 6 & 30.0 & 21 & 38.8 \\
\hline $\begin{array}{l}\text { External } \\
\text { Administrator }\end{array}$ & 13 & 38.2 & 10 & 50.0 & 23 & $\begin{array}{l}42.6 \\
\text { ontinued) }\end{array}$ \\
\hline
\end{tabular}




\begin{tabular}{lcccccc}
\hline Mentor Classification & RD & RD & RD & RD & RD & RD \\
& HEPC & HEPC & ACUHOI & ACUHOI & Total & $\begin{array}{c}\text { Total } \\
\%\end{array}$ \\
\hline Friend & 15 & 44.1 & 8 & 40.0 & 23 & 42.6 \\
Internal Colleague & 7 & 20.6 & 7 & 35.0 & 14 & 25.9 \\
External Colleague & 9 & 26.5 & 7 & 35.0 & 16 & 29.6 \\
$\begin{array}{l}\text { Professional } \\
\text { Organization }\end{array}$ & 4 & 11.8 & 4 & 20.0 & 8 & 14.8 \\
$\begin{array}{l}\text { Colleague } \\
\text { Other }\end{array}$ & & & & & & \\
Total Answered & 2 & & 0 & & 2 & 3.7 \\
Skipped Question & 34 & & 20 & & 54 & \\
\hline
\end{tabular}

Table 109 reflects that the majority of administrators classified their professional mentors as "Internal Colleague" with $87 \%(\mathrm{n}=7)$ rating this category. The HEPC and ACUHO-I survey results were similar in that the majority of respondents for both surveys classified the professional mentors as an "Internal Colleague."

Table 109

Administrators' Classification of Professional Mentors

\begin{tabular}{lcccccc}
\hline Mentor Classification & $\begin{array}{c}\text { Admin. } \\
\text { HEPC }\end{array}$ & $\begin{array}{c}\text { Admin. } \\
\text { HEPC }\end{array}$ & $\begin{array}{c}\text { Admin. } \\
\text { ACUHOI }\end{array}$ & $\begin{array}{c}\text { Admin. } \\
\text { ACUHOI }\end{array}$ & $\begin{array}{c}\text { Admin. } \\
\text { Total } \\
\text { N }\end{array}$ & $\begin{array}{c}\text { Admin. } \\
\text { Total } \\
\%\end{array}$ \\
\hline Internal Administrator & 0 & 0.0 & 3 & 75.0 & 3 & 37.5 \\
External Administrator & 0 & 0.0 & 1 & 25.0 & 1 & 12.5 \\
& & & & & & \\
(continued)
\end{tabular}




\begin{tabular}{|c|c|c|c|c|c|c|}
\hline Mentor Classification & $\begin{array}{c}\text { Admin. } \\
\text { HEPC } \\
\text { N }\end{array}$ & $\begin{array}{c}\text { Admin. } \\
\text { HEPC } \\
\%\end{array}$ & $\begin{array}{l}\text { Admin. } \\
\text { ACUHOI } \\
\mathrm{N}\end{array}$ & $\begin{array}{c}\text { Admin. } \\
\text { ACUHOI } \\
\%\end{array}$ & $\begin{array}{c}\text { Admin. } \\
\text { Total } \\
\text { N }\end{array}$ & $\begin{array}{c}\text { Admin. } \\
\text { Total } \\
\%\end{array}$ \\
\hline Friend & 1 & 25.0 & 1 & 25.0 & 2 & 25.0 \\
\hline Internal Colleague & 3 & 75.0 & 4 & 100.0 & 7 & 87.5 \\
\hline External Colleague & 1 & 25.0 & 1 & 25.0 & 2 & 25.0 \\
\hline $\begin{array}{l}\text { Professional } \\
\text { Organization Colleague }\end{array}$ & 0 & 0.0 & 1 & 25.0 & 1 & 12.5 \\
\hline Other & 0 & 0.0 & 0 & 0.0 & 0 & 0.0 \\
\hline Total Answered & 4 & & 4 & & 8 & \\
\hline Skipped Question & 22 & & 16 & & 38 & \\
\hline
\end{tabular}

Table 110 reflects that the majority of resident directors felt having a professional mentor contributed to their professional growth with $98.1 \%(n=53)$ rating this category. The HEPC and ACUHO-I survey results were similar in that the majority of respondents indicated that they felt having a professional mentor assisted their professional growth.

Table 110

Resident Directors Who Felt Having a Professional Mentor Assisted Professional Growth

\begin{tabular}{lcccccc}
\hline Assisted & RD & RD & RD & RD & RD & RD \\
Professional Growth & HEPC & HEPC & ACUHOI & ACUHOI & Total & Total \\
& N & $\%$ & N & $\%$ & N & $\%$ \\
\hline Yes & 33 & 97.1 & 20 & 100.0 & 53 & 98.1 \\
No & 1 & 2.9 & 0 & 0.0 & 1 & 1.9 \\
Total Answered & 34 & & 20 & & 54 & \\
Skipped Question & 33 & & 15 & & 48 & \\
\hline
\end{tabular}


Table 111 reflects that the majority of administrators felt having a professional mentor contributed to the professional growth of resident directors with $100 \%(\mathrm{n}=8)$ rating this category. The HEPC and ACUHO-I survey results were similar in that the majority of respondents indicated having a professional mentor assisted the resident directors' professional growth. Table 111 Administrators Who Felt Professional Mentors Assisted RDs' Professional Growth

\begin{tabular}{|c|c|c|c|c|c|c|}
\hline $\begin{array}{l}\text { Assisted } \\
\text { Professional } \\
\text { Growth }\end{array}$ & $\begin{array}{c}\text { Admin. } \\
\text { HEPC } \\
\mathrm{N}\end{array}$ & $\begin{array}{c}\text { Admin. } \\
\text { HEPC } \\
\%\end{array}$ & $\begin{array}{c}\text { Admin. } \\
\text { ACUHOI } \\
\mathrm{N}\end{array}$ & $\begin{array}{c}\text { Admin. } \\
\text { ACUHOI } \\
\%\end{array}$ & $\begin{array}{c}\text { Admin. } \\
\text { Total } \\
\text { N }\end{array}$ & $\begin{array}{c}\text { Admin. } \\
\text { Total } \\
\%\end{array}$ \\
\hline Yes & 4 & 100.0 & 4 & 100.0 & 8 & 100.0 \\
\hline No & 0 & 0.0 & 0 & 0.0 & 0 & 0.0 \\
\hline Total Answered & 4 & & 4 & & 8 & \\
\hline Skipped Question & 22 & & 16 & & 38 & \\
\hline
\end{tabular}

Table 112 reflects that the majority of resident directors felt having a professional mentor assigned to them was "Extremely Beneficial" or "Somewhat Beneficial" with 33.3\% (n=11) rating both of these categories. The HEPC and ACUHO-I results were not similar in that the majority of the HEPC resident directors felt that professional mentors were "Extremely Beneficial" and "Somewhat Beneficial" while the majority of the ACUHO-I resident directors felt professional mentors were "Somewhat Beneficial." 
Table 112

Resident Directors' Rating of Benefits of Having a Professional Mentor

\begin{tabular}{|c|c|c|c|c|c|c|}
\hline Benefit Rating & $\begin{array}{c}\text { RD } \\
\text { HEPC } \\
\mathrm{N} \\
\end{array}$ & $\begin{array}{c}\text { RD } \\
\text { HEPC } \\
\% \\
\end{array}$ & $\begin{array}{c}\mathrm{RD} \\
\text { ACUHOI } \\
\mathrm{N}\end{array}$ & $\begin{array}{c}\text { RD } \\
\text { ACUHOI } \\
\%\end{array}$ & $\begin{array}{c}\text { RD } \\
\text { Total } \\
\mathrm{N}\end{array}$ & $\begin{array}{c}\text { RD } \\
\text { Total } \\
\%\end{array}$ \\
\hline Extremely Beneficial & 9 & 36.0 & 2 & 25.0 & 11 & 33.3 \\
\hline Beneficial & 8 & 32.0 & 1 & 12.5 & 9 & 27.3 \\
\hline Somewhat Beneficial & 7 & 28.0 & 4 & 50.0 & 11 & 33.3 \\
\hline Rarely Beneficial & 1 & 4.0 & 1 & 12.5 & 2 & 6.1 \\
\hline Never Beneficial & 0 & 0.0 & 0 & 0.0 & 0 & 0.0 \\
\hline Total Answered & 25 & & 8 & & 33 & \\
\hline Skipped Question & 42 & & 27 & & 69 & \\
\hline
\end{tabular}

Table 113 reflects that the majority of administrators felt that having a professional mentor assigned to resident directors was "Somewhat Beneficial" with 50\% $(\mathrm{n}=14)$ rating this category. The HEPC and ACUHO-I survey results were similar in that the majority of respondents indicated that they felt having a professional mentor assigned to resident directors were "Somewhat Beneficial."

Table 113

Administrators' Rating of Benefits of Having a Professional Mentors Assigned to RDs

\begin{tabular}{|c|c|c|c|c|c|c|}
\hline Benefit Rating & $\begin{array}{c}\text { Admin. } \\
\text { HEPC } \\
\mathrm{N}\end{array}$ & $\begin{array}{c}\text { Admin. } \\
\text { HEPC } \\
\%\end{array}$ & $\begin{array}{c}\text { Admin. } \\
\text { ACUHOI } \\
\mathrm{N}\end{array}$ & $\begin{array}{c}\text { Admin. } \\
\text { ACUHOI } \\
\%\end{array}$ & $\begin{array}{c}\text { Admin. } \\
\text { Total } \\
\mathrm{N}\end{array}$ & $\begin{array}{c}\text { Admin. } \\
\text { Total } \\
\%\end{array}$ \\
\hline Extremely Beneficial & 3 & 18.8 & 0 & 0.0 & 3 & 10.7 \\
\hline Beneficial & 5 & 31.3 & 5 & 41.7 & 10 & 35.7 \\
\hline
\end{tabular}




\begin{tabular}{lcccccc}
\hline Benefit Rating & $\begin{array}{c}\text { Admin. } \\
\text { HEPC } \\
\text { N }\end{array}$ & $\begin{array}{c}\text { Admin. } \\
\text { HEPC } \\
\%\end{array}$ & $\begin{array}{c}\text { Admin. } \\
\text { ACUHOI } \\
\text { N }\end{array}$ & $\begin{array}{c}\text { Admin. } \\
\text { ACUHOI } \\
\%\end{array}$ & $\begin{array}{c}\text { Admin. } \\
\text { Total } \\
\mathrm{N}\end{array}$ & $\begin{array}{c}\text { Admin. } \\
\text { Total } \\
\%\end{array}$ \\
\hline Somewhat Beneficial & 8 & 50.0 & 6 & 50.0 & 14 & 50.0 \\
Rarely Beneficial & 0 & 0.0 & 1 & 8.3 & 1 & 3.6 \\
Never Beneficial & 0 & 0.0 & 0 & 0.0 & 0 & 0.0 \\
Total Answered & 16 & & 12 & & 28 & \\
Skipped Question & 10 & & 8 & & 18 & \\
\hline
\end{tabular}

\section{Comparison of Rewards and Benefits}

Table 114 reflects that the majority of resident directors are required to "Live-In" the residence hall with $88.5(\mathrm{n}=77)$ rating this category. The HEPC and ACUHO-I survey results were similar in that the majority of respondents indicated that they were required to "Live-In." Table 114

Resident Directors Required to Live-In Residence Halls

\begin{tabular}{lcccccc}
\hline Live-In & RD & RD & RD & RD & RD & RD \\
& HEPC & HEPC & ACUHOI & ACUHOI & Total & Total \\
& N & $\%$ & N & $\%$ & N & $\%$ \\
\hline Yes & 49 & 83.1 & 28 & 100.0 & 77 & 88.5 \\
No & 10 & 16.9 & 0 & 0.0 & 10 & 11.5 \\
Total Answered & 59 & & 28 & & 87 & \\
Skipped Question & 8 & & 7 & & 15 & \\
& & & & & & \\
\hline
\end{tabular}

Table 115 reflects that the majority of administrators required their resident directors to "Live-In" the residence hall with 100\% $(\mathrm{n}=40)$ rating this category. The HEPC and ACUHO-I 
survey results were similar in that the majority of respondents indicated that their institutions required resident directors to "Live-In".

Table 115

Administrators who Required RDs to Live-In Residence Halls

\begin{tabular}{lcccccc}
\hline Live-In & $\begin{array}{c}\text { Admin. } \\
\text { HEPC } \\
\text { N }\end{array}$ & $\begin{array}{c}\text { Admin. } \\
\text { HEPC } \\
\%\end{array}$ & $\begin{array}{c}\text { Admin. } \\
\text { ACUHOI }\end{array}$ & $\begin{array}{c}\text { Admin. } \\
\text { ACUHOI } \\
\%\end{array}$ & $\begin{array}{c}\text { Admin. } \\
\text { Total } \\
\text { N }\end{array}$ & $\begin{array}{c}\text { Admin. } \\
\text { Total } \\
\%\end{array}$ \\
\hline Yes & 21 & 100.0 & 19 & 100.0 & 40 & 100.0 \\
No & 0 & 0.0 & 0 & 0.0 & 0 & 0.0 \\
Total Answered & 21 & & 19 & & 40 & \\
Skipped Question & 5 & & 1 & & 6 & \\
\hline
\end{tabular}

Table 116 reflects that the majority of resident directors are on-call 24 hours a day, seven days a week during the academic year with $66.7 \%(n=58)$ rating this category. The HEPC and ACUHO-I survey results were similar in that the majority of respondents indicated that they were on-call 24 hours a day, seven days a week.

Table 116

Resident Directors On-Call 24 Hours/7 Days a Week during Academic Year

\begin{tabular}{|c|c|c|c|c|c|c|}
\hline On-Call & $\begin{array}{c}\text { RD } \\
\text { HEPC } \\
\mathrm{N}\end{array}$ & $\begin{array}{c}\text { RD } \\
\text { HEPC } \\
\%\end{array}$ & $\begin{array}{c}\text { RD } \\
\text { ACUHOI } \\
\mathrm{N}\end{array}$ & $\begin{array}{c}\text { RD } \\
\text { ACUHOI } \\
\%\end{array}$ & $\begin{array}{c}\text { RD } \\
\text { Total } \\
\mathrm{N}\end{array}$ & $\begin{array}{c}\text { RD } \\
\text { Total } \\
\%\end{array}$ \\
\hline Yes & 38 & 64.4 & 20 & 71.4 & 58 & 66.7 \\
\hline No & 21 & 35.6 & 8 & 28.6 & 29 & 33.3 \\
\hline Total Answered & 59 & & 28 & & 87 & \\
\hline Skipped Question & 8 & & 7 & & 15 & \\
\hline
\end{tabular}


Table 117 reflects that the majority of administrators did not require their resident directors to be on-call 24 hours a day, seven days a week during the academic year with $70 \%$ $(n=28)$ rating this category. The HEPC and ACUHO-I survey results were similar in that the majority of respondents indicated that they did not require their resident directors to be on-call 24 hours a day, seven days a week.

Table 117

Administrators who Required RDs On-Call 24 Hours/7 Days a Week

\begin{tabular}{lcccccc}
\hline On-Call & $\begin{array}{c}\text { Admin. } \\
\text { HEPC }\end{array}$ & $\begin{array}{c}\text { Admin. } \\
\text { HEPC }\end{array}$ & $\begin{array}{c}\text { Admin. } \\
\text { ACUHOI }\end{array}$ & $\begin{array}{c}\text { Admin. } \\
\text { ACUHOI } \\
\%\end{array}$ & $\begin{array}{c}\text { Admin. } \\
\text { Total } \\
\text { N }\end{array}$ & $\begin{array}{c}\text { Admin. } \\
\text { Total } \\
\%\end{array}$ \\
\hline Yes & 5 & 23.8 & 7 & 36.8 & 12 & 30.0 \\
No & 16 & 76.2 & 12 & 63.2 & 28 & 70.0 \\
Total Answered & 21 & & 19 & & 40 & \\
Skipped Question & 5 & & 1 & & & \\
\end{tabular}

Table 118 reflects that the majority of resident directors utilized a rotating on-call schedule for evening emergencies with $95.4 \%(n=83)$ rating this category. The HEPC and ACUHO-I survey results were similar in that the majority of respondents indicated that resident directors utilized a rotating on-call schedule.

Table 118

Resident Directors with Rotating On-Call Schedule for Evening Emergencies

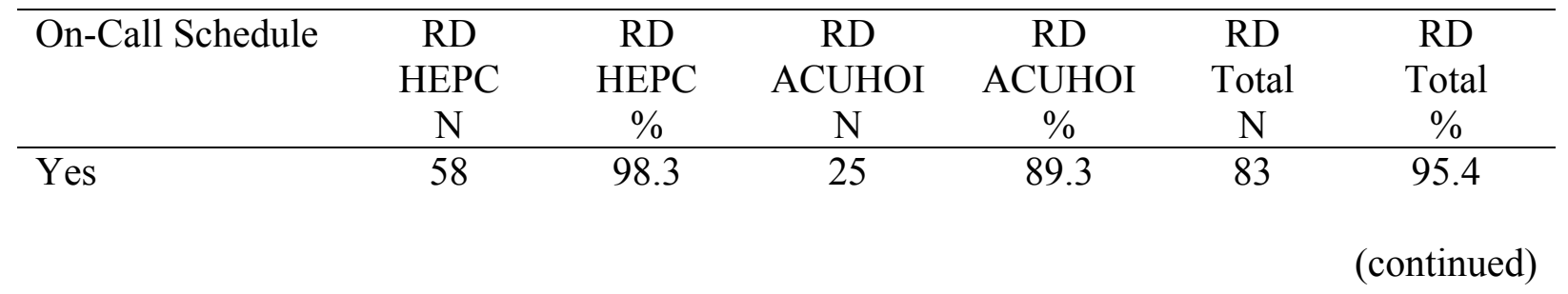




\begin{tabular}{lcccccc}
\hline On-Call Schedule & RD & RD & RD & RD & RD & RD \\
& HEPC & HEPC & ACUHOI & ACUHOI & Total & Total \\
& N & $\%$ & N & $\%$ & N & $\%$ \\
\hline No & 1 & 1.7 & 3 & 10.7 & 4 & 4.6 \\
Total Answered & 59 & & 28 & & 87 & \\
Skipped Question & 8 & & 7 & & 15 & \\
& & & & & & \\
\hline
\end{tabular}

Table 119 reflects that the majority of administrators provide their resident directors with a rotating on-call schedule for evening emergencies with $97.5 \%(n=39)$ rating this category. The HEPC and ACUHO-I survey results were similar in that the majority of respondents indicated that resident directors had a rotating on-call schedule.

Table 119

Administrators who Provided Rotating On-Call Schedule for Evening Emergencies

\begin{tabular}{lcccccc}
\hline On-Call Schedule & $\begin{array}{c}\text { Admin. } \\
\text { HEPC }\end{array}$ & $\begin{array}{c}\text { Admin. } \\
\text { HEPC }\end{array}$ & $\begin{array}{c}\text { Admin. } \\
\text { ACUHOI } \\
\text { N }\end{array}$ & $\begin{array}{c}\text { Admin. } \\
\text { ACUHOI }\end{array}$ & $\begin{array}{c}\text { Admin. } \\
\text { Total } \\
\text { Nes }\end{array}$ & $\begin{array}{c}\text { Admin. } \\
\text { Total } \\
\%\end{array}$ \\
No & 10 & 95.2 & 19 & 100.0 & 39 & 97.5 \\
Total Answered & 21 & 4.8 & 0 & 0.0 & 1 & 2.5 \\
Skipped Question & 5 & & 19 & & 40 & \\
& & & 1 & & 6 & \\
\hline
\end{tabular}

Table 120 reflects that the top two rewards and benefits that HEPC resident directors felt were "Very Important" was "Competitive Salary" and "Housing Arrangements". Table 121 reflects that the top two rewards and benefits that ACUHO-I resident directors felt were "Very Important" was "Competitive Salary" and a tie for "Housing Arrangements" and "Competitive Health.” The HEPC and ACUHO-I survey results were very similar in the ranking of 
importance in the rewards and benefits importance for consider the resident director position

offer.

Table 120

HEPC Resident Directors' Rating of Rewards and Benefits

\begin{tabular}{|c|c|c|c|c|c|c|}
\hline $\begin{array}{l}\text { Rewards \& } \\
\text { Benefits }\end{array}$ & $\begin{array}{c}\text { Very } \\
\text { Important } \\
\%(\mathrm{~N}) \\
\end{array}$ & $\begin{array}{c}\text { Somewhat } \\
\text { Important } \\
\%(\mathrm{~N}) \\
\end{array}$ & $\begin{array}{c}\text { Neutral } \\
\%(\mathrm{~N})\end{array}$ & $\begin{array}{c}\text { Somewhat } \\
\text { Unimportant } \\
\%(\mathrm{~N})\end{array}$ & $\begin{array}{c}\text { Unimportant } \\
\%(\mathrm{~N})\end{array}$ & $\begin{array}{c}\text { Response } \\
\text { Count }\end{array}$ \\
\hline Competitive Salary & $59.3(35)$ & $39.0(23)$ & $1.7(1)$ & $0.0(0)$ & $0.0(0)$ & 59 \\
\hline Competitive Health & $42.4(25)$ & $44.1(26)$ & $6.8(4)$ & $5.1(3)$ & $1.7(1)$ & 59 \\
\hline $\begin{array}{l}\text { Competitive } \\
\text { Retirement }\end{array}$ & $20.3(12)$ & $47.5(28)$ & $16.9(10)$ & $10.2(6)$ & $5.1(3)$ & 59 \\
\hline $\begin{array}{l}\text { Promotional } \\
\text { Opportunities }\end{array}$ & $35.6(21)$ & $35.6(21)$ & $18.6(11)$ & $6.8(4)$ & $3.4(2)$ & 59 \\
\hline $\begin{array}{l}\text { Married Partner } \\
\text { Benefits }\end{array}$ & $30.5(18)$ & $27.6(16)$ & $15.3(9)$ & $8.5(5)$ & $18.6(11)$ & 59 \\
\hline $\begin{array}{l}\text { Live-in Partner } \\
\text { Benefits }\end{array}$ & $25.9(15)$ & $27.6(16)$ & $27.6(16)$ & $5.2(3)$ & $13.8(8)$ & 59 \\
\hline Meal Plan & $15.3(9)$ & $49.2(29)$ & $20.3(12)$ & $10.2(6)$ & $5.1(3)$ & 59 \\
\hline $\begin{array}{l}\text { Housing } \\
\text { Arrangements }\end{array}$ & $50.8(30)$ & $40.7(24)$ & $8.5(5)$ & $0.0(0)$ & $0.0(0)$ & 59 \\
\hline Pets Permitted & $28.8(17)$ & $18.6(11)$ & $28.8(17)$ & $11.9(7)$ & $11.9(7)$ & 59 \\
\hline Skipped Question & & & & & & 8 \\
\hline
\end{tabular}


Table 121

ACUHO-I Resident Directors' Rating of Rewards and Benefits

\begin{tabular}{lcccccc}
\hline $\begin{array}{l}\text { Rewards \& } \\
\text { Benefits }\end{array}$ & $\begin{array}{c}\text { Very } \\
\text { Important } \\
\%(\mathrm{~N})\end{array}$ & $\begin{array}{c}\text { Somewhat } \\
\text { Important } \\
\%(\mathrm{~N})\end{array}$ & $\begin{array}{c}\text { Neutral } \\
\%(\mathrm{~N})\end{array}$ & $\begin{array}{c}\text { Somewhat } \\
\text { Unimportant } \\
\%(\mathrm{~N})\end{array}$ & $\begin{array}{c}\text { Unimportant } \\
\%(\mathrm{~N})\end{array}$ & $\begin{array}{c}\text { Response } \\
\text { Count }\end{array}$ \\
\hline Competitive Salary & $46.4(13)$ & $42.9(12)$ & $7.1(2)$ & $0.0(0)$ & $3.6(1)$ & 28 \\
Competitive Health & $42.9(12)$ & $39.3(11)$ & $10.7(3)$ & $3.6(1)$ & $3.6(1)$ & 28 \\
$\begin{array}{l}\text { Competitive } \\
\text { Retirement }\end{array}$ & $21.4(6)$ & $46.4(13)$ & $14.3(4)$ & $14.3(4)$ & $3.6(1)$ & 28 \\
$\begin{array}{l}\text { Promotional } \\
\text { Opportunities }\end{array}$ & $21.4(6)$ & $42.9(12)$ & $14.3(4)$ & $17.9(5)$ & $3.6(1)$ & 28 \\
$\begin{array}{l}\text { Married Partner } \\
\text { Benefits }\end{array}$ & $17.9(5)$ & $25.0(7)$ & $35.7(10)$ & $10.7(3)$ & $10.7(3)$ & 28 \\
$\begin{array}{l}\text { Live-in Partner } \\
\text { Benefits }\end{array}$ & $21.4(6)$ & $28.6(8)$ & $32.1(9)$ & $10.7(3)$ & $7.1(2)$ & 28 \\
Meal Plan & $35.7(10)$ & $46.4(13)$ & $17.9(5)$ & $0.0(0)$ & $0.0(0)$ & 28 \\
$\begin{array}{l}\text { Housing } \\
\text { Arrangements }\end{array}$ & $42.9(12)$ & $42.9(12)$ & $10.7(3)$ & $3.6(1)$ & $0.0(0)$ & 28 \\
Pets Permitted & $14.3(4)$ & $35.7(10)$ & $28.6(8)$ & $3.6(1)$ & $17.9(5)$ & 28 \\
Skipped Question & & & & & & 7 \\
\hline
\end{tabular}

Table 122 reflects that the top two rewards and benefits HEPC administrators felt were "Very Important" was "Competitive Salary" and "Competitive Health." Table 123 reflects that the top two rewards and benefits ACUHO-I administrators felt were "Very Important" was "Competitive Salary" and "Housing Arrangements." The HEPC and ACUHO-I survey results were somewhat similar in that the majority of respondents felt "Competitive Salary" were "Very 
Important" but HEPC administrators felt "Competitive Health" was also "Very Important" while ACUHO-I administrators felt "Housing Arrangements" was "Very Important."

Table 122

HEPC Administrators' Rating of Rewards and Benefits

\begin{tabular}{|c|c|c|c|c|c|c|}
\hline $\begin{array}{l}\text { Rewards \& } \\
\text { Benefits }\end{array}$ & $\begin{array}{c}\text { Very } \\
\text { Important } \\
\%(\mathrm{~N}) \\
\end{array}$ & $\begin{array}{c}\text { Somewhat } \\
\text { Important } \\
\%(\mathrm{~N}) \\
\end{array}$ & $\begin{array}{c}\text { Neutral } \\
\%(\mathrm{~N})\end{array}$ & $\begin{array}{c}\text { Somewhat } \\
\text { Unimportant } \\
\%(\mathrm{~N})\end{array}$ & $\begin{array}{c}\text { Unimportant } \\
\%(\mathrm{~N})\end{array}$ & $\begin{array}{l}\text { Response } \\
\text { Count }\end{array}$ \\
\hline Competitive Salary & $52.4(11)$ & $47.6(10)$ & $0.0(0)$ & $0.0(0)$ & $0.0(0)$ & 21 \\
\hline Competitive Health & $47.6(10)$ & $19.0(4)$ & $23.8(5)$ & $9.5(2)$ & $0.0(0)$ & 21 \\
\hline $\begin{array}{l}\text { Competitive } \\
\text { Retirement }\end{array}$ & $19.0(4)$ & $23.8(5)$ & $33.3(7)$ & $14.2(3)$ & $9.5(2)$ & 21 \\
\hline $\begin{array}{l}\text { Promotional } \\
\text { Opportunities }\end{array}$ & $19.0(4)$ & $38.1(8)$ & $23.8(5)$ & $19.0(4)$ & $0.0(0)$ & 21 \\
\hline $\begin{array}{l}\text { Married Partner } \\
\text { Benefits }\end{array}$ & $19.0(4)$ & $38.1(8)$ & $42.9(9)$ & $0.0(0)$ & $0.0(0)$ & 21 \\
\hline $\begin{array}{l}\text { Live-in Partner } \\
\text { Benefits }\end{array}$ & $19.0(4)$ & $42.9(9)$ & $28.6(6)$ & $0.0(0)$ & $9.5(2)$ & 21 \\
\hline Meal Plan & $14.3(3)$ & $42.9(9)$ & $33.3(7)$ & $9.5(2)$ & $0.0(0)$ & 21 \\
\hline $\begin{array}{l}\text { Housing } \\
\text { Arrangements }\end{array}$ & $42.9(9)$ & $28.6(6)$ & $28.6(6)$ & $0.0(0)$ & $0.0(0)$ & 21 \\
\hline Pets Permitted & 14.3(3) & $47.6(10)$ & $23.8(5)$ & $4.8(1)$ & $9.5(2)$ & 21 \\
\hline Skipped Question & & & & & & 5 \\
\hline
\end{tabular}


Table 123

ACUHO-I Administrators' Rating of Rewards and Benefit

\begin{tabular}{|c|c|c|c|c|c|c|}
\hline $\begin{array}{l}\text { Rewards \& } \\
\text { Benefits }\end{array}$ & $\begin{array}{c}\text { Very } \\
\text { Important } \\
\%(\mathrm{~N}) \\
\end{array}$ & $\begin{array}{c}\text { Somewhat } \\
\text { Important } \\
\%(\mathrm{~N})\end{array}$ & $\begin{array}{l}\text { Neutral } \\
\%(\mathrm{~N})\end{array}$ & $\begin{array}{c}\text { Somewhat } \\
\text { Unimportant } \\
\%(\mathrm{~N})\end{array}$ & $\begin{array}{l}\text { Unimportant } \\
\%(\mathrm{~N})\end{array}$ & $\begin{array}{l}\text { Response } \\
\text { Count }\end{array}$ \\
\hline Competitive Salary & $42.1(11)$ & $42.1(8)$ & $10.5(2)$ & $0.0(0)$ & $5.3(1)$ & 19 \\
\hline Competitive Health & $26.3(5)$ & $52.6(10)$ & $15.8(3)$ & $5.3(1)$ & $0.0(0)$ & 19 \\
\hline $\begin{array}{l}\text { Competitive } \\
\text { Retirement }\end{array}$ & $5.6(1)$ & $33.3(6)$ & $33.3(6)$ & $22.2(4)$ & $5.6(1)$ & 18 \\
\hline $\begin{array}{l}\text { Promotional } \\
\text { Opportunities }\end{array}$ & $21.1(4)$ & $57.9(11)$ & $15.8(3)$ & $5.3(1)$ & $0.0(0)$ & 19 \\
\hline $\begin{array}{l}\text { Married Partner } \\
\text { Benefits }\end{array}$ & $38.9(7)$ & $44.4(8)$ & $16.7(3)$ & $0.0(0)$ & $0.0(0)$ & 18 \\
\hline $\begin{array}{l}\text { Live-in Partner } \\
\text { Benefits }\end{array}$ & $27.8(5)$ & $50.0(9)$ & $22.2(4)$ & $0.0(0)$ & $0.0(0)$ & 18 \\
\hline Meal Plan & $15.8(3)$ & $47.4(9)$ & $31.6(6)$ & $5.3(1)$ & $0.0(0)$ & 19 \\
\hline $\begin{array}{l}\text { Housing } \\
\text { Arrangements }\end{array}$ & $42.1(8)$ & $47.4(9)$ & $10.5(2)$ & $0.0(0)$ & $0.0(0)$ & 19 \\
\hline Pets Permitted & $16.7(3)$ & $38.9(7)$ & $16.7(3)$ & $11.1(2)$ & $16.7(3)$ & 18 \\
\hline Skipped Question & & & & & & 1 \\
\hline
\end{tabular}

Table 124 reflects that the majority of HEPC resident directors felt "Very Satisfied" with their "Competitive Health" with over 50\% rating this category. Table 125 reflects that the majority of ACUHO-I resident directors felt "Very Satisfied" with their "Meal Plan" and "Housing Arrangements" with over 50\% rating these categories. The HEPC and ACUHO-I survey results were not similar in that HEPC resident directors were "Very Satisfied" with 
"Competitive Health" while ACUHO-I resident directors were "Very Satisfied with "Meal Plan" and "Housing Arrangements."

Table 124

HEPC Resident Directors' Satisfaction with Rewards and Benefits

\begin{tabular}{lcccccc}
\hline $\begin{array}{l}\text { Rewards \& } \\
\text { Benefits }\end{array}$ & $\begin{array}{c}\text { Very } \\
\text { Satisfied } \\
\%(\mathrm{~N})\end{array}$ & $\begin{array}{c}\text { Somewhat } \\
\text { Satisfied } \\
\%(\mathrm{~N})\end{array}$ & $\begin{array}{c}\text { Neutral } \\
\%(\mathrm{~N})\end{array}$ & $\begin{array}{c}\text { Somewhat } \\
\text { Unsatisfied } \\
\%(\mathrm{~N})\end{array}$ & $\begin{array}{c}\text { Unsatisfied } \\
\%(\mathrm{~N})\end{array}$ & $\begin{array}{c}\text { Response } \\
\text { Count }\end{array}$ \\
\hline Competitive Salary & $41.4(24)$ & $43.1(25)$ & $3.4(2)$ & $5.2(3)$ & $6.9(4)$ & 58 \\
Competitive Health & $51.7(30)$ & $37.9(22)$ & $8.6(5)$ & $1.7(1)$ & $0.0(0)$ & 58 \\
$\begin{array}{l}\text { Competitive } \\
\text { Retirement }\end{array}$ & $29.3(17)$ & $37.9(22)$ & $22.4(13)$ & $1.7(1)$ & $8.6(5)$ & 58 \\
$\begin{array}{l}\text { Promotional } \\
\text { Opportunities }\end{array}$ & $8.6(5)$ & $25.9(15)$ & $37.9(22)$ & $17.2(10)$ & $10.3(6)$ & 58 \\
$\begin{array}{l}\text { Married Partner } \\
\text { Benefits }\end{array}$ & $17.2(10)$ & $20.7(12)$ & $53.4(31)$ & $1.7(1)$ & $6.9(4)$ & 58 \\
$\begin{array}{l}\text { Live-in Partner } \\
\text { Benefits }\end{array}$ & $12.3(7)$ & $17.5(10)$ & $57.9(33)$ & $1.8(1)$ & $10.5(6)$ & 57 \\
Meal Plan & $19.0(11)$ & $31.0(18)$ & $15.5(9)$ & $13.6(8)$ & $20.7(12)$ & 58 \\
$\begin{array}{l}\text { Housing } \\
\text { Arrangements }\end{array}$ & $32.8(19)$ & $48.3(28)$ & $6.9(4)$ & $6.9(4)$ & $5.2(3)$ & 58 \\
Pets Permitted & $14.0(8)$ & $5.3(3)$ & $29.8(17)$ & $5(8.8)$ & $42.1(24)$ & 57 \\
Other & & & & & & 7 \\
Skipped Question & & & & & & 5 \\
\hline
\end{tabular}


Table 125

ACUHO-I Resident Directors' Satisfaction with Rewards and Benefits

\begin{tabular}{lcccccc}
\hline $\begin{array}{l}\text { Rewards \& } \\
\text { Benefits }\end{array}$ & $\begin{array}{c}\text { Very } \\
\text { Satisfied } \\
\%(\mathrm{~N})\end{array}$ & $\begin{array}{c}\text { Somewhat } \\
\text { Satisfied } \\
\%(\mathrm{~N})\end{array}$ & $\begin{array}{c}\text { Neutral } \\
\%(\mathrm{~N})\end{array}$ & $\begin{array}{c}\text { Somewhat } \\
\text { Unsatisfied } \\
\%(\mathrm{M})\end{array}$ & $\begin{array}{c}\text { Unsatisfied } \\
\%(\mathrm{~N})\end{array}$ & $\begin{array}{c}\text { Response } \\
\text { Count }\end{array}$ \\
\hline Competitive Salary & $39.3(11)$ & $50.0(14)$ & $10.7(3)$ & $0.0(0)$ & $0.0(0)$ & 28 \\
Competitive Health & $32.1(9)$ & $28.6(8)$ & $32.1(9)$ & $3.6(1)$ & $3.6(1)$ & 28 \\
$\begin{array}{l}\text { Competitive } \\
\text { Retirement }\end{array}$ & $21.4(6)$ & $25.0(7)$ & $46.4(13)$ & $7.1(2)$ & $0.0(0)$ & 28 \\
$\begin{array}{l}\text { Promotional } \\
\text { Opportunities }\end{array}$ & $3.6(1)$ & $28.6(8)$ & $50.0(14)$ & $14.3(4)$ & $3.6(1)$ & 28 \\
$\begin{array}{l}\text { Married Partner } \\
\text { Benefits }\end{array}$ & $14.3(4)$ & $21.4(6)$ & $57.1(16)$ & $3.6(1)$ & $3.6(1)$ & 28 \\
$\begin{array}{l}\text { Live-in Partner } \\
\text { Benefits }\end{array}$ & $14.3(4)$ & $17.9(5)$ & $53.6(15)$ & $0.0(0)$ & $14.3(4)$ & 28 \\
Meal Plan & $50.0(14)$ & $25.0(7)$ & $10.7(3)$ & $10.7(3)$ & $3.6(1)$ & 28 \\
$\begin{array}{l}\text { Housing } \\
\text { Arrangements }\end{array}$ & $50.0(14)$ & $42.9(12)$ & $3.6(1)$ & $3.6(1)$ & $0.0(0)$ & 28 \\
Pets Permitted & $21.4(6)$ & $0.0(0)$ & $21.4(6)$ & $7.1(1)$ & $14(50.0)$ & 28 \\
Other & & & & & & \\
Skipped Question & & & & & & \\
\hline
\end{tabular}

Table 126 reflects that the majority of HEPC administrators felt "Very Satisfied" with their institutions "Competitive Retirement" and "Competitive Health" with over 50\% rating these categories. Table 127 reflects that the majority of ACUHO-I administrators felt "Very Satisfied" with their institutions "Meal Plan" with over 50\% rating this category. The HEPC and ACUHO-I survey results were not similar in that HEPC administrators were "Very Satisfied" 
with their institutions "Competitive Retirement" and "Competitive Health" while ACUHO-I administrators were "Very Satisfied" with their institutions "Meal Plan."

Table 126

HEPC Administrators' Satisfaction with Rewards and Benefits Offered

\begin{tabular}{lcccccc}
\hline $\begin{array}{l}\text { Rewards \& } \\
\text { Benefits }\end{array}$ & $\begin{array}{c}\text { Very } \\
\text { Satisfied } \\
\%(\mathrm{~N})\end{array}$ & $\begin{array}{c}\text { Somewhat } \\
\text { Satisfied } \\
\%(\mathrm{~N})\end{array}$ & $\begin{array}{c}\text { Neutral } \\
\%(\mathrm{~N})\end{array}$ & $\begin{array}{c}\text { Somewhat } \\
\text { Satisfied } \\
\%(\mathrm{~N})\end{array}$ & $\begin{array}{c}\text { Unsatisfied } \\
\%(\mathrm{~N})\end{array}$ & $\begin{array}{c}\text { Response } \\
\text { Count }\end{array}$ \\
\hline Competitive Salary & $23.8(5)$ & $57.1(12)$ & $9.5(2)$ & $9.5(2)$ & $0.0(0)$ & 21 \\
Competitive Health & $61.9(13)$ & $38.1(8)$ & $0.0(0)$ & $0.0(0)$ & $0.0(0)$ & 21 \\
$\begin{array}{l}\text { Competitive } \\
\text { Retirement }\end{array}$ & $66.7(14)$ & $23.8(5)$ & $0.0(0)$ & $9.5(2)$ & $0.0(0)$ & 21 \\
$\begin{array}{l}\text { Promotional } \\
\text { Opportunities }\end{array}$ & $4.8(1)$ & $33.3(7)$ & $19.0(4)$ & $38.1(8)$ & $4.8(1)$ & 21 \\
$\begin{array}{l}\text { Married Partner } \\
\text { Benefits }\end{array}$ & $38.1(8)$ & $42.9(9)$ & $9.5(2)$ & $4.8(1)$ & $4.8(1)$ & 21 \\
$\begin{array}{l}\text { Live-in Partner } \\
\text { Benefits }\end{array}$ & $23.8(5)$ & $28.6(6)$ & $19.0(4)$ & $14.3(3)$ & $14.3(3)$ & 21 \\
Meal Plan & $42.9(9)$ & $28.6(6)$ & $19.0(4)$ & $4.8(1)$ & $4.8(1)$ & 21 \\
$\begin{array}{l}\text { Housing } \\
\text { Arrangements }\end{array}$ & $23.8(5)$ & $61.9(13)$ & $4.8(1)$ & $9.5(2)$ & $0.0(0)$ & 21 \\
$\begin{array}{l}\text { Pets Permitted } \\
\text { M. }\end{array}$ & & & & & & \\
\hline
\end{tabular}


Table 127

ACUHO-I Administrators' Satisfaction with Rewards and Benefits Offered

\begin{tabular}{|c|c|c|c|c|c|c|}
\hline $\begin{array}{l}\text { Rewards \& } \\
\text { Benefits }\end{array}$ & $\begin{array}{c}\text { Very } \\
\text { Satisfied } \\
\%(\mathrm{~N})\end{array}$ & $\begin{array}{c}\text { Somewhat } \\
\text { Satisfied } \\
\%(N)\end{array}$ & $\begin{array}{c}\text { Neutral } \\
\%(\mathrm{~N})\end{array}$ & $\begin{array}{c}\text { Somewhat } \\
\text { Unsatisfied } \\
\%(\mathrm{~N})\end{array}$ & $\begin{array}{c}\text { Unsatisfied } \\
\%(N)\end{array}$ & $\begin{array}{c}\text { Response } \\
\text { Count }\end{array}$ \\
\hline Competitive Salary & $47.4(4)$ & $42.1(8)$ & $5.3(1)$ & $0.0(0)$ & $5.3(1)$ & 19 \\
\hline Competitive Health & $36.8(7)$ & $57.9(11)$ & $5.3(1)$ & $0.0(0)$ & $0.0(0)$ & 19 \\
\hline $\begin{array}{l}\text { Competitive } \\
\text { Retirement }\end{array}$ & $47.4(9)$ & $36.8(7)$ & $10.5(2)$ & $5.3(1)$ & $0.0(0)$ & 19 \\
\hline $\begin{array}{l}\text { Promotional } \\
\text { Opportunities }\end{array}$ & $26.3(5)$ & $36.8(7)$ & $31.6(6)$ & $5.3(1)$ & $0.0(0)$ & 19 \\
\hline $\begin{array}{l}\text { Married Partner } \\
\text { Benefits }\end{array}$ & $38.9(7)$ & $55.6(10)$ & $5.6(1)$ & $0.0(0)$ & $0.0(0)$ & 18 \\
\hline $\begin{array}{l}\text { Live-in Partner } \\
\text { Benefits }\end{array}$ & $42.1(8)$ & $31.6(6)$ & $10.5(2)$ & $10.5(2)$ & $5.3(1)$ & 19 \\
\hline Meal Plan & $52.6(10)$ & $42.1(8)$ & $5.3(1)$ & $0.0(0)$ & $0.0(0)$ & 19 \\
\hline $\begin{array}{l}\text { Housing } \\
\text { Arrangements }\end{array}$ & $47.4(9)$ & $42.1(8)$ & $5.3(1)$ & $5.3(1)$ & $0.0(0)$ & 19 \\
\hline Pets Permitted & $16.7(3)$ & $22.2(4)$ & $22.2(4)$ & $22.2(4)$ & $16.7(3)$ & 18 \\
\hline
\end{tabular}

Resident directors were asked to provide any additional comments they felt would aid administrators with the retention of resident directors. Table 128 provides an excerpt of some direct comments made which reflect common themes. These main themes included: listening to them, giving them feedback, making them feeling valued, respecting their time investment, providing appropriate benefits, and investing in them as a professional. 
Table 128

Resident Directors' Comments Related to Resident Director Retention

Sample of Resident Directors' Comments with Recurring Themes

1. "Giving feedback (most of us are millenials!)"

2. "Show more appreciation for them- they're usually the ones doing all the dirty work but don't feel valued a lot of the time"

3. "In order to retain RDs, there needs to be greater attention paid to competitive salary/benefits and implementing efforts to minimize burn out."

4. "I believe Administration doesn't truly listen to our issues. Our time is not respected and we are continually putting in a standard 60 hour work week with no additional compensation."

5. "Positive affirmation is necessary for live-in staff. There can be a lot of negativity coming from below from students and above from the department that RDs often get put into a "crap sandwich" where no one is happy with them. I think people would be retained at higher rates if there were more professional development opportunities within departments and the ability to do some work that is not directly related to the building that you oversee."

6. "They need to pay them what they are worth and allow family to live with them if needed. Pets should be allowed. They need the ability to feel like what they are doing is getting them somewhere."

7. "Listen to feedback of RDs"

8. "I hate feeling marginalized. It is frustrating to be an underrepresented professional. .....Living in a 'college town', if you don't already have a partner, finding anyone to hang out with or socialize with becomes EXTREMELY difficult"

9. "Make sure that they feel valued and that their opinions are valued. All of our RDs have to serve on a committee with administration. This committee has both professionals and graduate students. The professionals treat the graduates like their opinion does not matter, and we usually feel like we don't even need to be at the meetings or helping out with the committee. Therefore either don't make us be on the committee, or take more of our opinions into consideration."

10. "Invest in them as a professional - don't micro manage and assume they can."

11. "Think outside the box, be flexible, let your people know just how much they are valued. And, let them have pets. :-)" 
Administrators were asked to provide any additional comments that they felt would aid administrators with the retention of resident directors. Table 129 provides an excerpt of some direct comments made which reflect common themes. The main themes included: addressing quality of life issues, providing professional growth opportunities, appropriately train, and provide better benefits.

Table 129

Administrators' Comments Related to Resident Director Retention

Sample of Administrators' Comments with Recurring Themes

1. "I think that most live-in staff at my institution would say that quality of life issues are largely ignored by our staff. Although that culture is shifting, it is still an area that requires on-going education for our colleagues (facilities, maintenance [sic], housekeeping, and other offices) so that they can appreciate the level of commitment that is required for a live-in professional to function professionally and personally in a residence hall."

2. "Creamer proves that it is mathematically wiser to retain staff than to hire new. They must feel that there are opportunities to learn and grow and contribute."

3. "Take time to really do training, one-on-one or as a group. Also, have lots of entry level positions so that there is that strong energy and excitement needed to bring in more new staff."

4. "We need to get better at letting RDs know how their current role, professional development and experiences will benefit them in the future so they can see the connection."

5. "Our RDs tend to stay 3 years or more. We have a mid-level Residence Life Coordinator job that allows them the opportunity to move up in the same department. Our liberal pet policy and live-in partner policy are also a great draw in helping professionals with personal balance."

6. "Listen to the directors; small things go a long way in satisfaction"

7. "Don't expect more of hall directors in terms of hours and responsibilities than is expected of higher level administrators."

8. "Pay more"

Resident directors were asked what they thought was the single most important factor that motivated them to work at their institution. Table 130 provides an excerpt of some direct 
comments made which reflect common themes. These main themes included: students, resident assistant staff, benefits, opportunities for professional growth, feeling valued, and the ability to work autonomously.

Table 130

Resident Directors' Comments on Single Most Important Motivating Factor

Sample of Resident Directors' Comments with Recurring Themes

1. "Feeling valued for the skills and knowledge that I bring to the table; being involved in the decision making process and asked to help execute tasks for projects that impact the department."

2. "Supporting student learning and growth"

3. "Opportunity to work autonomously, while still getting personalized support from supervisors."

4. "High level of student success and desire."

5. "The student contact that I have and the RAs that I supervise."

6. "Autonomy."

7. "My students, hands down"

8. "The students. I enjoy supervising Resident Assistants and working with the students in general."

9. "Opportunities (internships, working with other depts, etc.) that prepare me for a higher position in the future."

10. "The chance to positively impact students."

11. "Salary and benefits"

Administrators were asked what they thought was the single most important factor that motivated the resident directors to work at their institution. Table 131 provides an excerpt of some direct comments made which reflect common themes. These main themes included: institution reputation, location of institution, institutional benefits, professional development opportunities, and working with students. 
Table 131

Administrators' Comments on Single Most Important Motivating Factor

\section{Sample of Administrators' Comments with Recurring Themes}

1. "Reputation of our department, location, supervision opportunity"

2. "The opportunity to work at a very large school, in a very large Residence Life program. Our salary and apartment and professional development packages are all middle of the road in comparison to other places. The determining factor for staff is wanting to get a good experience to prepare them for a job at the next level and wanting to be in a college town."

3. "The combination between having a highly respected university of housing program, along with a highly respected graduate school that allows staff to pursue a masters or doctorate degree."

4. "Experience working in a quality program with great students"

5. "Professional Development and Growth/Opportunities."

6. "The desire to help students."

7. "The opportunity to impact students and their learning." 


\section{Chapter Five}

\section{Summary and Recommendations}

This chapter examines and summarizes the results of the data collected in this study. First, an overview of this study will be presented followed by the findings related to the research questions. Finally, this chapter will provide recommendations for best practice procedures and recommendations for future research.

\section{Summary}

The purpose of this research study was to determine best practices for the recruitment and retention of resident directors. This study first examined the hiring qualifications and training at 18 institutions; 11 identified by the Association of College \& University Housing Officer International (ACUHO-I) Commissioned Research Program (Ellett, et. al., 2008) as having best practices in the recruitment and/or retention of resident directors and seven institutions selected from West Virginia University's (WVU) Higher Education Policy Commission (HEPC) peer institutions. This study also examined factors within these institutions' organizational culture that contributed to the retention of resident directors.

\section{Participant and Institutional Background Information}

As shown in Table 132, 362 residence life staff members (245 resident directors and 117 residence life administrators) were asked to complete the surveys. An overall response rate of $40 \%$ was achieved. The HEPC institutional response rate (49.5\%) was higher than the response rate of the ACUHO-I peers (30\%). A total of 148 residence life staff members (102 resident directors and 46 residence life administrators) responded to the surveys. 
Table 132

Population and Respondents of HEPC and ACUHO-I Institutions

\begin{tabular}{|c|c|c|c|c|c|c|c|}
\hline Participants & $\begin{array}{c}\text { RD } \\
\text { HEPC }\end{array}$ & $\begin{array}{c}\text { RD } \\
\text { ACUHOI }\end{array}$ & $\begin{array}{c}\text { RD } \\
\text { Total }\end{array}$ & $\begin{array}{l}\text { Admin. } \\
\text { HEPC }\end{array}$ & $\begin{array}{l}\text { Admin. } \\
\text { ACUHOI }\end{array}$ & $\begin{array}{c}\text { Admin. } \\
\text { Total }\end{array}$ & $\begin{array}{c}\text { Survey } \\
\text { Totals }\end{array}$ \\
\hline Population & 132 & 113 & 245 & 52 & 65 & 117 & 362 \\
\hline Respondents & 67 & 35 & 102 & 26 & 20 & 46 & 148 \\
\hline Percentage & 49.0 & 30.0 & 41.6 & 50.0 & 30.0 & 39.3 & 40.8 \\
\hline
\end{tabular}

Note. $\mathrm{RD}=$ resident director; Admin.= residence life administrator; HEPC=WVU's Higher Education Policy Commission Peer Institutions; ACUHOI=Association of College \& University Housing Officer International Commissioned Research Program (Ellett, et. al., 2008) best practice institutions.

The majority of the resident director respondents were white $(76.2 \%)$, females $(58 \%)$, between the ages $26-30(43.5 \%)$, who had either two $(29.6 \%)$ or five or more years $(29.6 \%)$ resident director experience. The majority of the administrator respondents were white (91.1\%), females $(55.6 \%)$, between the ages of $30-35$ (34.8\%), who had five or more years $(92.9 \%)$ residence life administrator experience.

The majority of HEPC respondents' residence hall populations consisted of mostly freshmen while the majority of ACUHO-I respondents' residence hall populations consisted of both freshmen and upperclassmen. The gender within the respondents' residence halls was mixed with both males and females.

The responses reflect that the typical resident director is required to live-in the residence halls and supervise $8-15$ resident assistants. Only $28.8 \%$ had a live-in spouse or partner. While their responsibilities are too numerous to list, their main responsibilities consist of crisis management, supervision of para-professional staff, serving as a student conduct hearing officer, daily operation of the hall, student programming, and serving as a student organization advisor. Some resident directors held budget officer and facilities management responsibilities while even 
fewer were responsible for the instruction of a first-year seminar course and supervision of professional staff.

A summary of the results related to the research questions follows.

Research Question One. "How well prepared are resident directors to assume their demanding leadership role?"

\section{Level of Preparation}

Resident directors were "Adequately Prepared" to assume the responsibilities of their position when they were first hired and were "Very Well Prepared" to handle their responsibilities at the time the survey was conducted (i.e. after serving in the position and completing at least one year of training). Administrators concurred that they were "Adequately Prepared" when they were first hired but felt they were "Well Prepared" after at least one year in the position.

\section{Recruitment of Resident Directors}

Both ACUHO-I and HEPC administrators indicated that they were "Always" able to hire high quality resident directors. However, ACUHO-I administrators rated "Always" 23.7\% higher than their HEPC peers. The most common recruitment and advertisement methods utilized by administrators to market the resident director position vacancies were institutional postings, professional organization postings, national advertisements, and recruitment fairs.

The findings from this dissertation research contradicts earlier research conducted by Belch \& Mueller (2003) and Scheuermann \& Ellett (2007). Their research indicated that there is a growing concern at many institutions with the recruitment and retention of residence life and housing staff. The findings of this dissertation research have shown that institutions who utilize appropriate recruitment methods do not have a concern, or face a crisis, when it comes to hiring 
high quality resident directors. However this does not necessarily contradict the problems associated with resident director retention described in their research.

Research Question One (a): “What qualifications (skills, education, and experience) do institutions require for resident directors?"

\section{Qualifications}

Skills. Resident directors and administrators agreed that "Communication" and "Interpersonal" skills were the most important skills for resident directors to possess. Resident directors felt "Time Management" and "Leadership" skills were also critical. "Computer" skills were generally not considered relevant to the resident director position.

Education. Administrators indicated that their institutions required resident directors to have a minimum of a Masters degree. Administrators were "Always" able to hire resident directors who met the minimum educational requirements. The majority of the resident directors possessed a Masters degree when they were first hired and held a Masters degree at the time of the survey.

The majority of the resident directors surveyed were not enrolled in a degree program at the time of the survey. Only $53 \%$ of the resident directors planned to enroll in degree program in the near future. Those who planned to enroll in a degree program planned to enroll in a doctoral degree program.

Experience. Administrators indicated that resident assistant experience was not a requirement for the resident director position, yet the majority of resident directors possessed two to three years resident assistant experience. Administrators indicated that student affairs experience was not a requirement for the resident director position; however the majority of 
resident directors possessed two to three years student affairs experience; most likely this experience was as a resident assistant.

Research Question One (b). "What types of training are resident directors provided?"

\section{Training}

Resident directors typically assumed their duties 30 to 60 days before the start of the academic year. Resident directors were required to participate in training before the halls opened with the initial training lasting more than one week. Resident directors indicated that the main training topics included: Supervision, Crisis Management, Student Conduct, Programming, and Daily Hall Operations. Administrators included Safety and Security as one of the main topics of training. ACUHO-I resident directors felt their initial training was "Extremely Valuable" while HEPC resident directors felt their initial training was "Very Valuable." Both ACUHO-I and HEPC administrators felt the initial training was "Extremely Valuable."

Resident directors were also required to participate in training after the halls opened for the academic semester. In fact, the majority indicated that they were required to participate in training on a monthly basis. There was more diversity and variance in the topics covered during the training after the halls opened. The three main training topics included: Student Conduct, Supervision, and Crisis Management. HEPC resident directors rated training after the halls opened up as "Somewhat Valuable" while ACUHO-I resident directors rated this training as "Very Valuable." However, HEPC administrators rated training after the halls opened as "Extremely Valuable" while the majority of ACUHO-I administrators rated this training as "Very Valuable."

Overall, the majority of respondents felt that resident directors were appropriately trained to fulfill the responsibilities of their positions. Only a few resident directors (13.6\%) and 
administrators (2.5\%) indicated that the resident directors were not appropriately trained to fulfill their responsibilities. Supervision, Counseling/Mentoring, Crisis Management, Student Conduct, Daily Hall Operations, and Safety and Security were listed as the areas in which additional training would be helpful.

Research Question Two. "How likely is a resident director to be retained based on the institution's organizational culture?"

\section{Retention and Organizational Culture}

The participating institutions typically had 11-15 full-time resident directors on staff with one year or less resident director experience. These resident directors were "Highly Likely" to continue at their current institution the following year. HEPC resident directors planned to continue at their current institution one year or less or two years while the majority of ACUHO-I resident directors planned to continue as a resident director at their current institution for one to three years. HEPC administrators thought it was "Highly Likely" for resident directors to continue at their current institution one year or less while ACUHO-I administrators felt it was "Highly Likely" for resident directors to continue at the institution for two years.

Once a resident director left his or her position at their current institution, it was "Highly Unlikely" that they would continue as a resident director at another institution. The majority of resident directors indicated they would leave the resident director position for "Another Position," as opposed to leaving their position because of job burn-out, not wanting to live in, or because they felt under-appreciated. Administrators concurred that it was "Very Common" for resident directors to leave the resident director position for "Another Position" as opposed to other factors. 
The research of this dissertation has shown that resident directors do not necessarily leave their position due to quality of life issues or job burn-out. There simply is no intent for many resident directors to stay in their position for longer than two or three years. In a study conducted by Belch and Mueller (2003) of chief housing officers and graduate students, they determined that "quality of life, remuneration, and lack of interest in the residence life profession were significant issues" (p.29) that affected the declining number of resident directors. Belch and Mueller's research demonstrates there is a lack of interest in the resident director position as a profession. This dissertation research did not examine whether or not resident directors planned to stay in the residence life profession as a career choice. Future research on the residence life profession as a career choice is suggested.

Respected and Valued. Resident directors felt less respected and less valued by administration than what administrators reported. Additionally, HEPC resident directors felt less respected and less valued than their ACUHO-I peers. For example, HEPC and ACUHO-I resident directors felt "Respected" by department administration. While HEPC administrators felt resident directors were "Respected" by department administration, ACUHO-I administrators felt they were and "Highly Respected." HEPC resident directors felt they were "Somewhat Respected" by university administration while ACUHO-I resident directors felt they were "Respected." HEPC and ACUHO-I administrators felt resident directors were "Respected" by university administration.

HEPC resident directors felt "Somewhat Valued" as a staff member while ACUHO-I resident directors felt "Very Valued." HEPC administrators felt resident directors were equally "Extremely Valued" and "Very Valued" while ACUHO-I administrators felt resident directors were "Extremely Valued" as a staff member. 
Performance Feedback and Autonomous Operation. HEPC resident directors were provided with performance feedback "Occasionally" while ACUHO-I resident directors were provided with performance feedback “Often.” HEPC and ACUHO-I administrators felt they provided performance feedback "Often."

HEPC and ACUHO-I resident directors felt they were able to operate autonomously "Very Often." HEPC administrators felt they allowed resident directors to operate autonomously "Very Often" while ACUHO-I administrators felt they allowed resident directors to operate autonomously "Often."

Research Question Two (a). "What types of professional development opportunities exist?"

Professional Development. Resident directors felt they were encouraged to develop professionally by administration "Very Often." However, HEPC resident directors felt less encouraged to develop professionally than their ACUHO-I peers. Administrators concurred that they encouraged professional development "Very Often." Administrators provided funding for tuition for formal classes, presenting at conferences, and attending conferences without presenting. The majority of resident directors attended conferences and/or were members of professional organizations. Very few took advantage of the formal education offered by their institution's administration. HEPC resident directors participated in professional development opportunities less often than their ACUHO-I peers.

Research Question Two (b). What type of mentoring occurs?

Mentoring. While most institutions did not have a formal mentoring program, the majority of the resident directors had an administrator or friend they consider to be a professional mentor. HEPC resident directors had internal administrator mentors while ACUHO-I resident 
directors had external administrator mentors. Both resident directors and administrators indicted that having a professional mentor was beneficial and contributed to the resident directors' professional growth.

Research Question Two (c). "What types of rewards and benefits are offered?"

Rewards and Benefits. All of the ACUHO-I institutions required resident directors to livein, and the vast majority (83.1\%) of HEPC institutions required resident directors to live-in. The majority of the resident directors reported that they had to be on call 24 hours a day, seven days a week during the academic year. Both resident directors and administrators stated that a rotating, on-call scheduled was used for evening emergencies.

Resident directors felt that salary, housing arrangements, and health insurance were the most important rewards and benefits when making a decision about a position offer. Administrators concurred that these were the most important factors regarding decisions about the position. HEPC resident directors were "Very Satisfied" with their health and "Somewhat Satisfied" with their salary and housing arrangements. ACUHO-I resident directors were "Very Satisfied" with their meal plan and housing arrangements and "Somewhat Satisfied" with their salary. Of the benefits and reward found to be the most important by resident directors, HEPC administrators felt "Very Satisfied" with their institution's health insurance benefits and "Somewhat Satisfied" with their salary and housing arrangements. ACUHO-I administrators felt "Very Satisfied" with salary and housing arrangements and "Somewhat Satisfied" with health insurance benefits.

Research Question Three. "How do recruitment and retention practices at ACUHO-I best practice institutions compare to those at WVU's HEPC peer institutions?" 


\section{Comparison of HEPC and ACUHO-I Institutions}

While WVU's HEPC peer institutions' recruitment and retention practices were similar in many areas to ACUHO-I best practice institutions, ACUHO-I institutions had some better practices, in general, than HEPC institutions. Table 133 provides a brief overview of the areas that were not similar.

Table 133

Comparison of Institutions

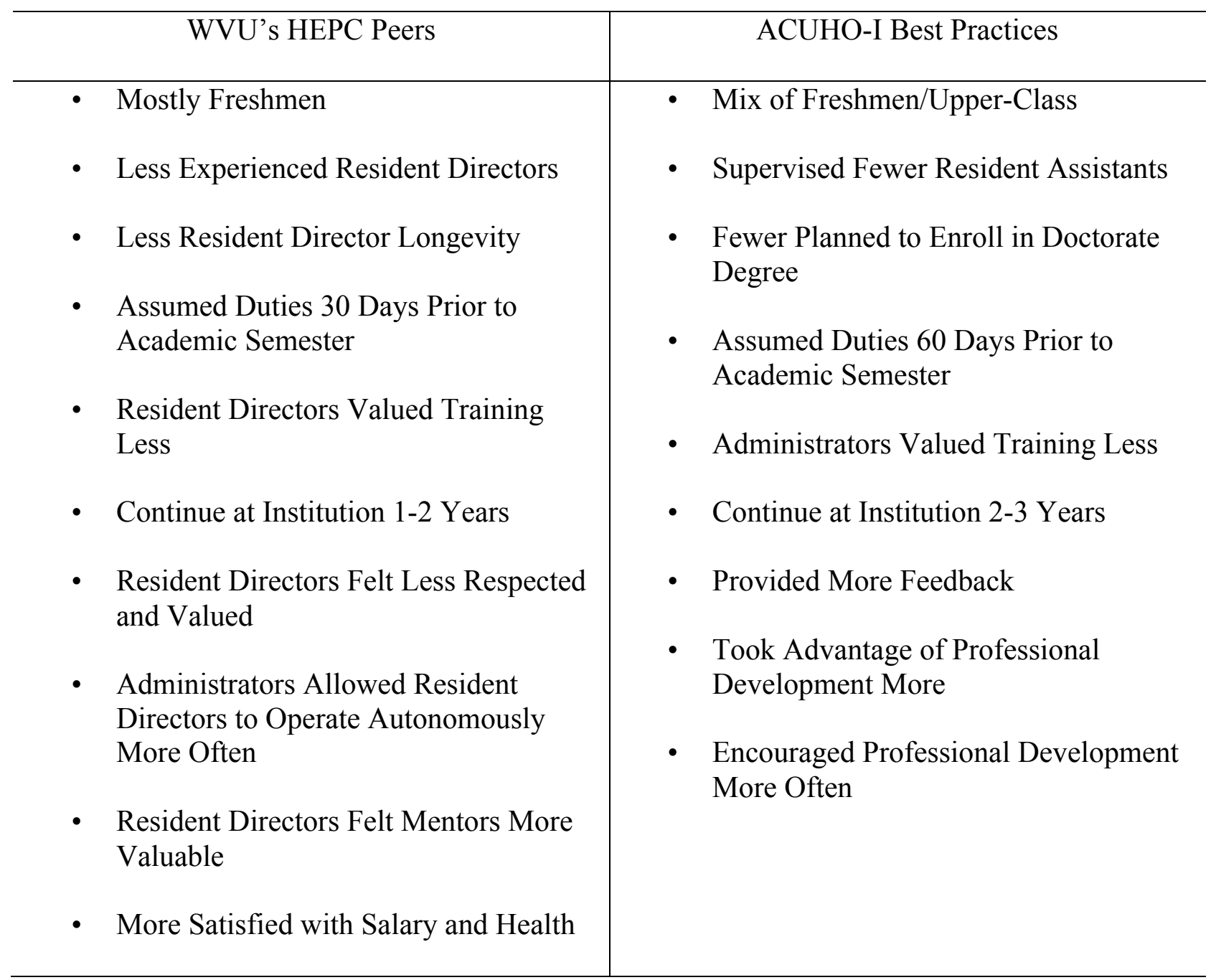


As summarized in Table 133, the following areas were not similar with respect to recruitment and retention practices:

Residence Hall Academic Class Rank. HEPC institutions had mostly freshmen in the residence hall while ACUHO-I residence halls had a mix of freshmen and upper-class.

Resident Director Experience/Longevity. HEPC resident directors had less resident director experience at their current institution than ACUHO-I resident directors. The majority of the HEPC resident directors were in their position "One Year or Less" or "Two Years" while the majority of ACUHO-I resident directors were in their position "Two Years" or "Five or More Years." Additionally, 25\% of the ACUHO-I resident directors had at least five years or more resident director experience compared to $11.7 \%$ of the HEPC resident directors who had five years or more experience. This seems to indicate that ACUHO-I institutions had a higher resident director retention rate than their HEPC peers.

Supervision. HEPC resident directors supervised more Resident Assistants (RAs) compared to their ACUHO-I peers. The majority of ACUHO-I and HEPC resident directors supervised 8-15 RAs. However, only 8.5\% ACUHO-I resident directors supervised 16 or more RAs compared to $32.9 \%$ of the HEPC resident directors who supervised 16 or more RAs.

Education. The majority of HEPC resident directors (57.1\%) planned to enroll in a degree program in the near future while the majority of ACUHO-I resident directors $(55.0 \%)$ did not plan to enroll in a degree program in the near future.

Training. The majority of HEPC resident directors typically assumed duties 30 days prior to the start of the academic semester while the majority of ACUHO-I resident directors typically assumed duties 60 days prior to the start of the semester. The HEPC resident directors rated the value of training lower than their ACUHO-I peers. However, HEPC administrators 
rated the value of training higher than the ACUHO-I administrators rated the value of training. HEPC resident directors indicated more training in "Daily Hall Operations" was needed while ACUHO-I resident directors felt more training in "Safety and Security" was needed.

Retention. HEPC resident directors planned to continue at their current institution one year or less while their ACUHO-I peers planned to continue at their current institution three years. HEPC administrators also thought the resident directors would stay one year or less while ACUHO-I administrators thought their resident directors would remain two years.

Respected and Valued. HEPC resident directors felt less respected and valued by department and university administration than their ACUHO-I peers.

Performance Feedback. HEPC resident directors were provided with feedback less often than their ACUHO-I peers.

Operate Autonomously. HEPC administrators allowed resident directors to operate autonomously more often than their ACUHO-I peers.

Professional Development. HEPC resident directors were encouraged to develop professionally less often than their ACUHO-I peers. HEPC resident directors also took advantage of professional development opportunities less often than their ACUHO-I peers.

Mentors. HEPC resident directors felt mentors were more beneficial than did their ACUHO-I peers. The HEPC resident director mentors were classified as internal administrators while the ACUHO-I resident directors mentors were classified as external administrators.

Benefits. HEPC resident directors were more satisfied with the benefits that they found to be very important (such as salary and health) than their ACUHO-I peers. 


\section{Recommendations}

\section{Recommendations for Practice}

Based upon the results of this study, the following recommendations are advised:

\section{Require resident director candidates to have a minimum of a Masters degree.}

According to earlier research, $57.6 \%$ of entry-level housing staff living in a residence hall completed their bachelor's degree (St. Onge, Ellett \& Nestor, 2008). Some institutions filled their resident director positions with part-time graduate students and a small number of institutions hired undergraduate students to fill this important role (Horowitz, 2009).

Hire professionals with appropriate skill sets over experience. Irby (2000) stated that "additional specializations, demonstrated knowledge, and job-relevant know-how have increasing currency in the work place" (Wright \& Miller, 2007, p. 152). Resident assistant and student affairs experience may be useful for candidates to possess, however it is not necessarily the most important factor when considering candidates. Hiring officials should be more concerned about the skill sets the candidates possess. Hiring officials should look for candidates who possess strong communication and interpersonal skills. They should also display good time management and leadership abilities. Resident directors are unlikely to leave their current position to become a resident director at another institution. Hiring officials need to recognize that it is unlikely to hire a candidate that has resident director experience. Additionally, resident assistant and resident director experience may hinder longevity in the position.

Invest in multiple recruitment methods. Hiring administrators need to utilize multiple methods of advertisements so that they can ensure the maximum number of qualified candidates are given consideration. These methods include institutional postings, professional organizational postings, national advertisements, and attending recruitment fairs. The money 
invested in recruitment will reap dividends by acquiring highly qualified candidates who will excel in the residence hall environment. Since it is unlikely for resident directors to leave their position for another resident director position, recruitment initiatives should not target current resident directors. It is more important to focus marketing initiatives on recent graduates from educational programs and/or current resident assistants.

Hire resident directors at least 60 days prior to the start of the academic year. Timing of the hiring process is important for training purposes. This additional time allows for resident directors to acclimate themselves before training begins. Resident directors who were hired 60 days prior to the academic year felt training was more valuable than those who were hired only 30 days prior to the beginning of the academic year. Hiring officials need to recruit and finalize the hiring process at least two months prior to the beginning of the academic semester.

\section{Review salary and health benefits at other institutions to ensure appropriate}

remuneration. Resident directors are more likely to accept a position based on the salary than any other factor. Hiring officials should keep in mind that housing arrangements and health plans are also considered to be "Very Important" to resident directors when making a decision about accepting a position. If hiring administrators do not have any influence to change salary or health benefits offered at their institutions, they should ensure housing arrangements are either equivalent or better than other institutions to remain competitive.

Appropriately manage the resident directors' responsibilities. Newly hired resident directors should supervise approximately 15 resident assistants. Unfortunately, this is not always possible given the design and layout of the residence halls, which often fluctuate in size. Administrators should consider assigning newly hired resident directors to smaller halls with smaller number of resident assistants on staff. Administrators should also be cognizant of the 
additional duties that they assign to resident directors. Most institutions do not require resident directors to teach a first-year seminar course and fewer resident directors supervise professional staff members. If the institution has resident directors that stay on-board longer than two or three years, the administrators may consider adding additional duties, such as those mentioned above, to resident directors who have more experience.

Set-up a rotating, on-call schedule to allow resident directors time off. While resident directors need to live-in the residence hall and be available 24 hours a day, seven days a week during the academic year, it is important for administrators to set-up an on-call, rotating schedule. This allows resident director much needed personal time away from their position's demanding schedule, while still providing emergency coverage and care of the students.

Provide on-going training throughout the year. The initial training for resident directors should begin about two months prior to when the residence halls open. This training should last about two weeks and include the following topics: supervision, crisis management, student conduct, programming, daily hall operations, and safety management. Once the residence halls open, resident directors should participate in additional training on the same topics. The additional training should also include counseling/mentoring and budget management, if applicable. This training should occur on a regular, monthly basis. Personalized, one-on-one training is also recommended. Because the typical resident director does not plan to remain in the position for much longer than two or three years, administrators should review the cost benefits of training materials. In house training or training videos that can be reused might be good suggestions in place of hiring outside training consultants. Additional research in this area would prove to be useful. 


\section{Invest in professional development wisely by creating individualized professional}

development plans. Residence life administrators need to recognize that the resident director position is an entry-level professional position. Longevity in the position beyond two or three years is dependent upon the resident directors' likelihood to obtain another position.

Administrators need to realize that investing in professional development is something that "just makes good sense" in assisting young professionals develop their skills for future opportunities. Administrators should set-up a professional development plan designed to meet the needs of each resident director. For example, if the resident director does not plan to stay in residence life or student affairs conduct, then investing in national conferences such as the Association of College and University Housing Officers-International (ACUHO-I) or the Association for Student Conduct Administration (ASCA) may not be best for that particular resident director.

Administrators should ensure that resident directors have a mentor. This does not need to be formalized. Administrators should designate several staff members that could serve as possible mentors. The mentor partnership could be further developed through the professional development plan. Administrators may want to look at professional development activities that the mentor and resident director can participate in together, such as attending or presenting at conferences.

Provide feedback on a monthly basis. Resident directors' supervisors should have regular monthly meeting with each resident director. During these meetings, they should provide feedback on their performance and discuss their professional development plans. Supervisors should also seek input from resident directors on institutional missions, plans, goals, and initiatives so that resident directors feel that their opinions are valued. 


\section{Resident life administrators need to find venues to showcase the importance of the}

resident director position. This will ensure that the value of the position is understood at all levels of the institutions' administration.

Residence life administrators need to realize that resident directors are important, crucial personnel. They are entry-level, young professionals who want to enhance and develop their professional skills. Administrators should embrace this fact and understand that resident directors will not remain in the position for a long period of time. It is the responsibility of their administrators to assist them with their professional growth. Administrators should balance the supervisor/mentor role so that consistent feedback encourages professional growth. If this is done appropriately, the resident directors will feel more valued and perform at a high levels during their tenure.

\section{Recommendations for Future Research}

\section{Future research should examine the motivating factors behind the resident directors'}

career choices. This research has shown that resident directors typically do not intend to remain in the position for a longer than two or three years. However, the "recruitment and retention of competent, if not excellent, housing and residential life staff are essential to our success as professionals and as a profession" (St. Onge, Ellett, \& Nestor, 2008, p. 11). This research has shown that there continues to be a concern with the retention of resident directors. Future research should examine the motivating factors behind the resident directors' career choices. Additionally, it would be important to understand what types of positions resident directors leave their resident director position for. Analysis of subsequent career positions (i.e., residence life, student affairs, higher education, or other positions) might prove to be useful with retention initiatives. Future research on the resident directors' career goals and educational offerings 
could help determine how the residence life profession has evolved over the years.

Understanding this will assist administrators in the development of practices that can promote residence life as a thriving profession to young professionals.

\section{Future research should delve into the specifics of resident directors' initial and on-}

going training. This research has also shown that hiring resident directors with appropriate skill sets may be more important, and more likely to occur, than hiring someone with directly related residence hall experience. This makes training critical to the success of the institution's residence life mission. This research touched on training topics and the length of training. This research recommended training for resident directors prior to the residence halls opened and training throughout the semester. Future research should delve into the specifics of resident directors' initial and on-going training. A study of training materials utilized by institutions, the method of delivery of the training materials, and the cost associated with the training will assist administrators in providing high quality, cost effective training.

Future research should be conducted on residence hall staffs' living environment. The majority (75\%) of the resident directors who responded to the survey had one to three years resident assistant experience. Perhaps part of the reason why resident directors intend to remain in the position for only two or three years is due to their previous live-in resident assistant experience. The fact that they had lived in the residence hall as a resident assistant for one-three years prior to the resident director position may be a factor for their decision to leave the position sooner than resident directors without resident assistant experience. HEPC resident directors were "Highly Likely" to leave the resident director position because they did not want to live-in. They ranked this at a much higher percentage (43.9\%) than their ACUHO-I peers (7.1\%). Future research should be conducted on why HEPC resident directors would leave because they did not 
want to live-in compared to their ACUHO-I peers. A review of resident directors' living environment (i.e., housing location on student floor or separate apartment entrance), and policies and/or procedures that affect both the resident assistants' and the resident directors' living environment (i.e., alcohol policies, pet policies, smoking policies, etc.) will prove to be useful in understanding more about factors affecting the resident directors desire to leave the position.

Future research should be conducted on how administrators, at institutions who have difficulty recruiting or retaining resident director candidates, utilize ACUHO-I venues. ACUHO-I best practice institutions were designated best practice institutions for a reason. One of the common themes that administrators for both HEPC and ACUHO-I institutions stated was the single most important factor that motivated resident directors to work at their institution was the institution's reputation. The ACUHO-I organization provides venues for administrators to share best practices. Future research should be conducted on how administrators, at institutions with lower resident director retention rates and institutions, who have difficulty recruiting resident director candidates, utilize these venues.

Future research should be conducted on how ACUHO-I best practice schools accomplish having Resident Directors feel valued and respected. Finally, this research has shown that ACUHO-I best practice institutions have done an excellent job at making the resident directors on staff feel respected and valued. Future research on how these schools accomplish this will greatly aid other residence life administrators ensure resident directors at their institution feel more valued and respected. "While (extrinsic) rewards are important (Anderson et al, 2000; Solmon \& Tierney, 1977), intrinsic rewards are more highly valued among student affairs professional. Engaging in meaningful work, operating autonomously, and influencing 
major decisions are all intrinsic in nature and are all more highly valued by student affairs professionals" (Hirt, Amelink, \& Schneiter in Collins \& Hirt, 2006, p. 6). 


\section{References}

Anderson, J. E., Guido-DiBrito, F., \& Morrell, J. S. (2000). Factors that influence satisfaction for student affairs administrators. In Collins, D., \& Hirt, J. (2006, June). The Nature of Professional Life for Residence Hall Administrators. Journal of College \& University Student Housing, 34(1), 14-24. Retrieved from Academic Search Complete database.

ACUHO-I (2010). Association of College and University Housing Officers. Retrieved from http://www.acuho-i.org/AboutUs/tabid/61/Default.aspx.

Allen, K. E., \& Cherrey, C. (2000). Systematic leadership: Enriching meaning in our work. In Belch, H. A. Wilson, M. E., \& Dunkel, N. (2009). Cultures of success: Recruiting and retaining new live-in residence life professionals. College Student Affairs Journal, 27(2) 176. Retrieved from Academic Search Complete database

Anderson, J. E., Guido-DiBrito, F. \& Morrell, J. S. (2000). Factors that influence satisfaction for student affairs administrators. In Collins, D., \& Hirt, J. (2006, June). The Nature of Professional Life for Residence Hall Administrators. Journal of College \& University Student Housing, 34(1), 14-24. Retrieved from Academic Search Complete database.

Archer, J., \& Cooper, S. (1998). Counseling and mental health services on campus. In Upcraft, M.L., Garnder, J. N., Barefoot, B.O., \& Associates (2005). Challenging and Supporting the First-Year Student. Jossey-Bass San Francisco, CA 1st Edition.

Astin, A.W. (1993). What matters in college?in Palmer, C., Broido, E., \& Campbell, J. (2008, October). A commentary on the educational role in college student housing. Journal of College \& University Student Housing, 35(2), 86-99. Retrieved from Academic Search Complete database. 
Baker R. \& Siryk, B. (1980). Alienation and freshmen transition into college. Journal of College Student Personnel, 23, 348-350.

Barr, M. J., \& Desler, M. K. (2000). Leadership for the future. In Roberts, D. M. (2007). Preferred methods of professional development in student affairs. NASPA Journal, 44(3), 561-577.

Belch, H. A., \& Muller J. A. (2003). Candidate pools or puddles: Challenges and trends in the recruitment and hiring of resident directors. Journal of College Student Development, 44(1), 29-46.

Belch, H. A. Wilson, M. E., \& Dunkel, N. (2009). Cultures of success: Recruiting and retaining new live-in residence life professionals. College Student Affairs Journal, 27(2) 176. Retrieved from Academic Search Complete database

Berwick, K. R. (1992). Stress among student affairs administrators: The relationship of personal characteristics and organizational variables to work-related stress. In Collins, D., \& Hirt, J. (2006, June). The Nature of Professional Life for Residence Hall Administrators. Journal of College \& University Student Housing, 34(1), 14-24. Retrieved from Academic Search Complete database.

Bliming, G.S. (1993). New challenges and goals for residential life programs. In Belch, H. A., \& Muller J. A. (2003). Candidate pools or puddles: Challenges and trends in the recruitment and hiring of resident directors. Journal of College Student Development. 44(1), 29-46.

Canon, A. J. (1980). Developing staff potential. In Grace-Odeleye, B. (1998). A modelf for staff development in student affairs. New Directions for Student Services, 84, 83-93. 
Caplan, G., \& Grunebaum, H. (1967). Perspectives on primary intervention. In Waldo, M. (1989). Primary prevention in university residence halls: Paraprofessional-led relationship enhancement groups for college roommates. Journal of Counseling and Development, 67(8), 465-71. Retrieved from ERIC database

Carnegie Foundation for the Advancement of Teaching (2011). The classification of institutions of higher education. Retrieved from http://classifications.carnegiefoundation.org/ Chandler, L.A., \& Gallegher, R.P. (1996). Developing a taxonomy for problems seen at university counseling center. Measurement and evaluation in Counseling and Development, 29, 4-12.

Chickering. A. W. (1969). Education and identity. In Waldo, M. (1989). Primary prevention in university residence halls: Paraprofessional-led relationship enhancement groups for college roommates. Journal of Counseling and Development, 67(8), 465-71. Retrieved from ERIC database.

Collins, D., \& Hirt, J. (2006, June). The Nature of Professional Life for Residence Hall Administrators. Journal of College \& University Student Housing, 34(1), 14-24. Retrieved from Academic Search Complete database.

Creswell, J. W. (2003). Research design ( $2^{\text {nd }}$ ed.). Thousand Oaks: Sage Publications.

Davis, B. J., Winston, R. B. Jr. (2006). Supervision of new professionals in student affairs: Assessing and addressing needs. College Student Affairs Journal, 26, 64-89.

Deluga, R. J. \& Winters, J.J. Jr. (1990). The impact of role ambiguity and conflict on resident assistants. Journal of College Student Development, 31(3), 230-236.

Denison, D. R., (1996). What is the difference between organizational culture and organizational climate? A native's point of view on a decade of paradigm wars. In Belch, H. A. Wilson, 
M. E., \& Dunkel, N. (2009). Cultures of success: Recruiting and retaining new live-in residence life professionals. College Student Affairs Journal, 27(2) 176. Retrieved from Academic Search Complete database

Dunkel, N.W., \& Schreiber, P. J. (1992). Competency development of housing professionals. Journal of College and University Student Housing, 22(2), 19-23.

Ellett, T. E., Belch, H. A., Christopher, J., \& St. Onge, S. R (2008). Recruitment and Retention of Entry-Level Staff in Housing and Residence Life: A report on activities supported by the (ACUHO-I) Commissioned Research Program. Retrieved from www.acuhoi.org/Portals/0/pdf/hiring_retention_report_fnl.pdf.

Fey, C. J., (1991). Mid-level student affairs administrators: A study of management skills and professional development needs. In Sermersheim, K., \& Keim, M. (2005). Mid-level student affairs managers: Skill importance and need for continued professional development. College Student Affairs Journal, 25(1), 36-49. Retrieved from Education Research Complete database.

Frederiksen, C.F. (1993). A brief history of collegiate housing. In Palmer, C., Broido, E., \& Campbell, J. (2008, October). A Commentary on The Educational Role in College Student Housing. Journal of College \& University Student Housing, 35(2), 86-99. Retrieved June 13, 2009, from Academic Search Complete database.

Frydenberg, E. (1997). Adolescent coping: Theoretical and research perspectives. In Jones, B. \& Frydenberg, E. (1999). Who needs help and when: Coping with the transition from school 
to university. Proceeding of the Annual Conference of American Educational Research Association, Montreal, Canada. Retreived from ERIC database. (ED 430203).

Gentry, W. A., Harris, L.S., \& Nowicki, S. (2007). Recognition of emotion in facial expressions and resident advisor effectiveness. Journal of College and University Student Housing, 34(2), 61-67.

Gerst, M.S. \& Sweetwood, H. (1973). Correlates of dormitory social climate. In Waldo, M. (1989). Primary prevention in university residence halls: Paraprofessional-led relationship enhancement groups for college roommates. Journal of Counseling and Development, 67(8), 465-71. Retrieved from ERIC database.

Goebel, J. (1976). Alienation in dormitory life. in Waldo, M. (1989). Primary prevention in university residence halls: Paraprofessional-led relationship enhancement groups for college roommates. Journal of Counseling and Development, 67(8), 465-71. Retrieved from ERIC database.

Harris, S. G., \& Mossholder, K. W. (1996). The affective implications of perceived congruence with cultural dimensions during organizational transformation. In Belch, H. A. Wilson, M. E., \& Dunkel, N. (2009). Cultures of success: Recruiting and retaining new live-in residence life professionals. College Student Affairs Journal, 27(2) 176. Retrieved from Academic Search Complete database.

HigherEd Jobs.com. Resident Director, Drexel University. Retrieved from http://www.higheredjobs.com/search/details.cfm?JobCode=175468627 on October 15, 2010. 
HigherEd Jobs.com. Resident Coordinators(s), Trinity Washington University. Retrieved from http://www.higheredjobs.com/search/details.cfm?JobCode=175476325 on November 6, 2010.

HigherEd Jobs.com. Residential Learning Coordinator (Multiple Positions), Virginia Tech. Retrieved from http://www.higheredjobs.com/search/details.cfm?JobCode=175476172 on November 6, 2010.

Hirt, J. B. Amelink, C. T., \& Schreiber, P. J. (1992). Competency development of housing professionals. In Collins, D., \& Hirt, J. (2006, June). The Nature of Professional Life for Residence Hall Administrators. Journal of College \& University Student Housing, 34(1), 14-24. Retrieved from Academic Search Complete database.

Horowitz, R. (2009). The 2009 Live-in/on report. Retrieved from http://www.residentassistant.com/2009Report.doc.

Irby, B. J. (2000). The career advancement portfolio. In Wright, D., Miller, T. D. (2007). Training higher education policy makers and leaders: a graduate program perspective. Charlotte, NC: IAP

Johnsrud, L. K., Heck, R. H. \& Rosser, V. J. (2000). Morale matters: Midlevel administrators and their intent to leave. In Collins, D., \& Hirt, J. (2006, June). The Nature of Professional Life for Residence Hall Administrators. Journal of College \& University Student Housing, 34(1), 14-24. Retrieved from Academic Search Complete database.

Johnsrud, L. K., \& Rosser, V. J., (1999). College and university mid-level administrators: Explaining and improving their morale. In Collins, D., \& Hirt, J. (2006, June). The Nature of Professional Life for Residence Hall Administrators. Journal of College \& 
University Student Housing, 34(1), 14-24. Retrieved from Academic Search Complete database.

Jones, B. \& Frydenberg, E. (1999). Who needs help and when: Coping with the transition from school to university. Proceeding of the Annual Conference of American Educational Research Association, Montreal, Canada. Retreived from ERIC database. (ED 430203).

Jones, D. P. (2002). College housing professionals at the crossroads. Journal of College and University Student Housing, 31(1). 8-12.

Kane, N. E. (1982). A comparative study of student affairs mid-level professionals: Characteristics, perceived skill attainment and need for continued development. In Roberts, D. M. (2007). Preferred methods in professional development in student affairs. NASPA Journal, 44(3), 561-577.

Kearney, P. A. (1993). Professional staffing. In Winston, R. B. Jr., Anchors, S. \& Associates (1993). Student housing and residential life. 269-291. San Francisco: Jossey-Bass.

Kuh, G.D., \& Whitt, E. J. (1988). The invisible tapestry: Culture in american colleges. In Belch, H. A. Wilson, M. E., \& Dunkel, N. (2009). Cultures of success: Recruiting and retaining new live-in residence life professionals. College Student Affairs Journal, 27(2) 176. Retrieved from Academic Search Complete database

Lemoine, J. A. (1985). Professional development for mid-level student affairs professioansl at the small college. In Sermersheim, K., \& Keim, M. (2005). Mid-level student affairs managers: Skill importance and need for continued professional development. College Student Affairs Journal, 25(1), 36-49. Retrieved from Education Research Complete database. 
Miller, C. J. \& Coyne, R. K. (1980). Paraprofessional problems: A comparison of residence hall paraprofessionals and regular students. In Benjamin, M. (2007). Role construction of residential learning community peer mentors. Journal of College and University Student Housing, 34(2), 31-41

Miller, T. K. (1975). Staff development activities in student affairs programs. In Sermersheim, K., \& Keim, M. (2005). Mid-level student affairs managers: Skill importance and need for continued professional development. College Student Affairs Journal, 25(1), 36-49. Retrieved from Education Research Complete database.

NASPA (2010). National Association of Student Personnel Administrators. Standards of professional practice. Retrieved from http://www.naspa.org/about/standards.cfm.

Nelson, J. (2005). Christina Maslach. In Ellett, T. E., Belch, H. A., Christopher, J., \& St. Onge, S. R (2008). Recruitment and Retention of Entry-Level Staff in Housing and Residence Life: A report on activities supported by the (ACUHO-I) Commissioned Research Program. Retrieved from www.acuho-i.org/Portals/0/pdf/hiring_retention_report_fnl.pdf

Palmer, C., Broido, E., \& Campbell, J. (2008, October). A Commentary on the educational role in college student housing. Journal of College \& University Student Housing, 35(2), 8699. Retrieved June 13, 2009, from Academic Search Complete database.

Pascarella, E.T., \& Terenzini, P.T. (1991). How college affects students: Findings and insights from twenty years of research. San Francisco: Jossey-Bass in Palmer, C., Broido, E., \& Campbell, J. (2008, October). A commentary on the educational role in college student 
housing. Journal of College \& University Student Housing, 35(2), 86-99. Retrieved from Academic Search Complete database.

Reslife.net (2010). Resident assistant training. Retrieved at http://reslife.net/html/training in July 2010.

Rickgarn, R. L. V. (1988, Ocotber). Suicidal encounters. Journal of Counseling Development, 67(2), 97-98.

Riker, H.C. (1965). College housing as learning centers. Washington D.C.: American College Personnel Association, in Riker, H., \& Decoster, D. (2008, October). The Educational Role in College Student Housing. Journal of College \& University Student Housing, 35(2), 80-85. Retrieved from Academic Search Complete database.

Sandeen, A. \& Barr, M. J. (2006). Critical issues for student affairs: Challenges and opportunities. San Francisco: Jossey-Bass.

Sax, L. J., Gilmartin, S. K., Keup, J. R., DiCrisi, F. A., \& Bryant, A. N. (2000). Designing an assessment of the first college year: Results from the 1999-2000 YFCY pilot study. In Dillon, J. J., (2003). Bringing counseling to the classroom and the residence hall: The university learning communities. Journal of Humanistic Counseling, Education and Development, 42, 194-208.

Schein, E. H. (1999). The corporate cultural survival guide: Sense and nonsense about cultural change. In Belch, H. A. Wilson, M. E., \& Dunkel, N. (2009). Cultures of success: Recruiting and retaining new live-in residence life professionals. College Student Affairs Journal, 27(2) 176. Retrieved from Academic Search Complete database. 
Schein, E. H. (2004). Organizational culture and leadership. In Belch, H. A. Wilson, M. E., \& Dunkel, N. (2009). Cultures of success: Recruiting and retaining new live-in residence life professionals. College Student Affairs Journal, 27(2) 176. Retrieved from Academic Search Complete database.

Scheuermann, T., \& Ellett, T. A. (2007). A 3D view of recruitment and retention of entry-level housing staff: Déjà vu, deliberation, decisive ction. Journal of College and University Student Housing, 34 (2) 12-19.

Schmidt, J., \& Wolfe, J. (2009). The mentor partnership: Discovery of professionalism. NASPA Journal (National Association of Student Personnel Administrators, Inc.), 46(3), 371381. Retrieved from Education Research Complete database.

Schreiber, P. J., Dunkel, N.W., \& Jahr, P. K. (1994). Compency based development programs. The College Student Affairs Journal, 14(1), 23-30.

Schroeder, C. C., Mable, P. \& Associates. (1994). Realizing the educational potential of residence halls. In Palmer, C., Broido, E., \& Campbell, J. (2008, October). A Commentary on The Educational Role in College Student Housing.. Journal of College \& University Student Housing, 35(2), 86-99. Retrieved June 13, 2009, from Academic Search Complete database.

Sermersheim, K., \& Keim, M. (2005). Mid-level student affairs managers: Skill importance and need for continued professional development. College Student Affairs Journal, 25(1), 3649. Retrieved from Education Research Complete database. 
Silver, H. (2004). Residence and Accommodation in Higher Education: Abandoning a Tradition. Journal of Educational Administration and History, 36(2), 123-133. Retrieved from ERIC database.

Sims, R. R. (1994). Ethics and organizational decision making: A call for renewal. In Belch, H. A. Wilson, M. E., \& Dunkel, N. (2009). Cultures of success: Recruiting and retaining new live-in residence life professionals. College Student Affairs Journal, 27(2) 176. Retrieved from Academic Search Complete database.

Solomon, L. C., \& Tierney, M. L. (1977). Determinants of job satisfaction among college administrators. Journal of Higher Education, 48, 412-431. Retrieved from EBSCO host database.

Stimpson, R. (1994). Creating a context for educational success. In Belch, H. A., \& Muller J. A. (2003). Candidate pools or puddles: Challenges and trends in the recruitment and hiring of resident directors. Journal of College Student Development. 44(1), 29-46.

St. Onge, S., Nestor, E., Peter, P., \& Robertson, T. (2004). Modifying RA training in support of a custom programming model. Journal of College \& University Student Housing, 33(1), 45-48. Retrieved from Education Research Complete database.

St. Onge S., Ellett, T., \& Nestor, E. (2008, October). Factors Affecting Recruitment and Retention of Entry-Level Housing and Residential Life Staff: Perceptions of Chief Housing Officers. Journal of College \& University Student Housing, 35(2), 10-23. Retrieved from Academic Search Complete database. 
Upcraft, M.L., Garnder, J. N., Barefoot, B.O., \& Associates (2005). Challenging and Supporting the First-Year Student. Jossey-Bass San Francisco, CA.

Waldo, M. (1989). Primary prevention in university residence halls: Paraprofessional-led relationship enhancement groups for college roommates. Journal of Counseling and Development, 67(8), 465-71. Retrieved from ERIC database.

Ward, L. (1995). Role stress and propensity to leave among new student affairs professionals. In Collins, D., \& Hirt, J. (2006, June). The Nature of Professional Life for Residence Hall Administrators. Journal of College \& University Student Housing, 34(1), 14-24.

Retrieved June 13, 2009, from Academic Search Complete database.

Winston, R.B. Jr., \& Anchors, S. (1993). Ensuring staff competence. In Belch, H. A., \& Muller J. A. (2003). Candidate pools or puddles: Challenges and trends in the recruitment and hiring of resident directors. Journal of College Student Development. 44(1), 29-46.

Winston, R.B. Jr., \& Fitch, R. T. (1993). Paraprofessional staffing. In Benjamin, M. (2007). Role construction of residential learning community peer mentors. Journal of College and University Student Housing, 34(2), 31-41

Wright, D., Miller, T. D. (2007). Training higher education policy makers and leaders: a graduate program perspective. Charlotte, NC: IAP

Workforce Planning for Wisconsin State Government. (2005). Employee retention. Retrieved at http://www.cs.state.ny.us/successionplanning/ workgroups/Retention/employee retentionreport.pdf. 


\section{APPENDIX A}

Survey Regarding Best Practices for the Recruitment and Retention of Resident Directors submitted to Resident Directors 


\section{Recruitment \& Retention of Resident Directors (RD Survey-HEPC Peers)}

\section{Demographiles}

Please answer the following demographic questions:

\section{What is your gender?}
Male
Female
Transgender

\section{What is your age?}
Under 20
20.25
26-30
31.35
Over 35

3. What is your ethnic affiliation?
African American/Black
White/Caucasian/European American
Asian American/Pacific Islander
MultiRacial
Hispanic American/Lation/Chicano
Other or Prefer Not to Answer
Native American/Tribal Affiliation

4. Do you have a live-in spouse or partner?
Yes
No

\section{What is your official title?}

\section{Background Information}

Note: While various titles are utilized for similiar positions (i.e. Residence Hall Coordinator, Area Advisor, Complex Director) throughout this survey the term Resident Director will be utlized. 
Recruitment \& Retention of Resident Directors (RD Survey-HEPC Peers)

6. How many years have you been a Resident Director?

1 year or less
2 years
3 years
4 years
5 years or more

7. How many years have you been a Resident Director at your current institution?

1 year or less

2 years

3 years

4 years

5 years or more

8. What is the academic class rank of students living in the residence hall you oversee?

Mostly freshmen

$\bigcirc$ Mostly upper-class

Mix of freshmen and upper-class

9. What is the gender of students living in the residence hall you oversee?

Mostly males
Mostly females
Mix of females and males

10. What of the following job duties are you responsible for? (please check all that apply)

$\square$ Daily Hall Operations

$\square$ Student Programming

$\square$ Supervision of Para-professional Staff

Facilities Managemen

$\square$ Supervision of Professional Staff

$\square$ Student Conduct Hearing Officer

Crisis Management

$\square$ Instructor of First-Year Course

$\square$ Student Organization Advisor

Other (please specify) 
Recruitment \& Retention of Resident Directors (RD Survey-HEPC Peers)
Less than 7 RAs
8-15RAS
16-20 RAs
21-25 RAs
More than 25

11. How many Resident Assistants (RAs) do you supervise?

12. When you first became a Resident Director, overall, how prepared were you to assume the responsibilitites of the position?

Very Well Prepared
well Prepared
Adequately Prepared
Poorly Prepared
Very Poorly Prepared

13. How prepared do you feel you are to handle the responsibilities of the Resident Director position now?

Very Well Prepared
well Prepared
Adequately Prepared
Poorly Prepared
Very Poorly Prepared

14. How important are the following skills in preparing you to assume your duties?

\begin{tabular}{|c|c|c|c|c|c|}
\hline & Very Important & Somewhat Important & Neutral & $\begin{array}{l}\text { Somewhat } \\
\text { Unimportant }\end{array}$ & Unimportant \\
\hline \multicolumn{6}{|l|}{ Interpersonal } \\
\hline \multicolumn{6}{|l|}{ Leadership } \\
\hline \multicolumn{6}{|c|}{ Personnel Management } \\
\hline \multicolumn{6}{|l|}{ Communication } \\
\hline \multicolumn{6}{|l|}{ Time Management } \\
\hline \multicolumn{6}{|l|}{$\begin{array}{l}\text { Student Mentoring or } \\
\text { Counseling }\end{array}$} \\
\hline \multicolumn{6}{|l|}{ Problem Solving } \\
\hline Conflict Resolution & & & & & \\
\hline Computer & & & & & \\
\hline
\end{tabular}


Recruitment \& Retention of Resident Directors (RD Survey-HEPC Peers)

15. Please list any other skill(s) not listed above that you believe to be "Very Important" or "Important" for a Resident Director to possess.

\section{Edrotation}

16. What is the highest level of education you have completed to date?
Some Undergraduale Work
Bachelors
$\bigcirc$ Some Graduate Work
$\bigcirc$ Masters
Doctorate

17. What was the highest level of education you had when you first accepted the Resident Director posittion?
$\bigcirc$ Some Undergraduate Work
Bachelors
$\bigcirc$ Some Graduate Work
$\bigcirc$ Masters
$\bigcirc$ Doctorate

18. Are you currently enrolled in a degree program?

Yes

No

\section{Education}

19. What degree are you pursuing?

$\bigcirc$ Bachelors

Masters

$\bigcirc$ Doctorate

\section{Education}




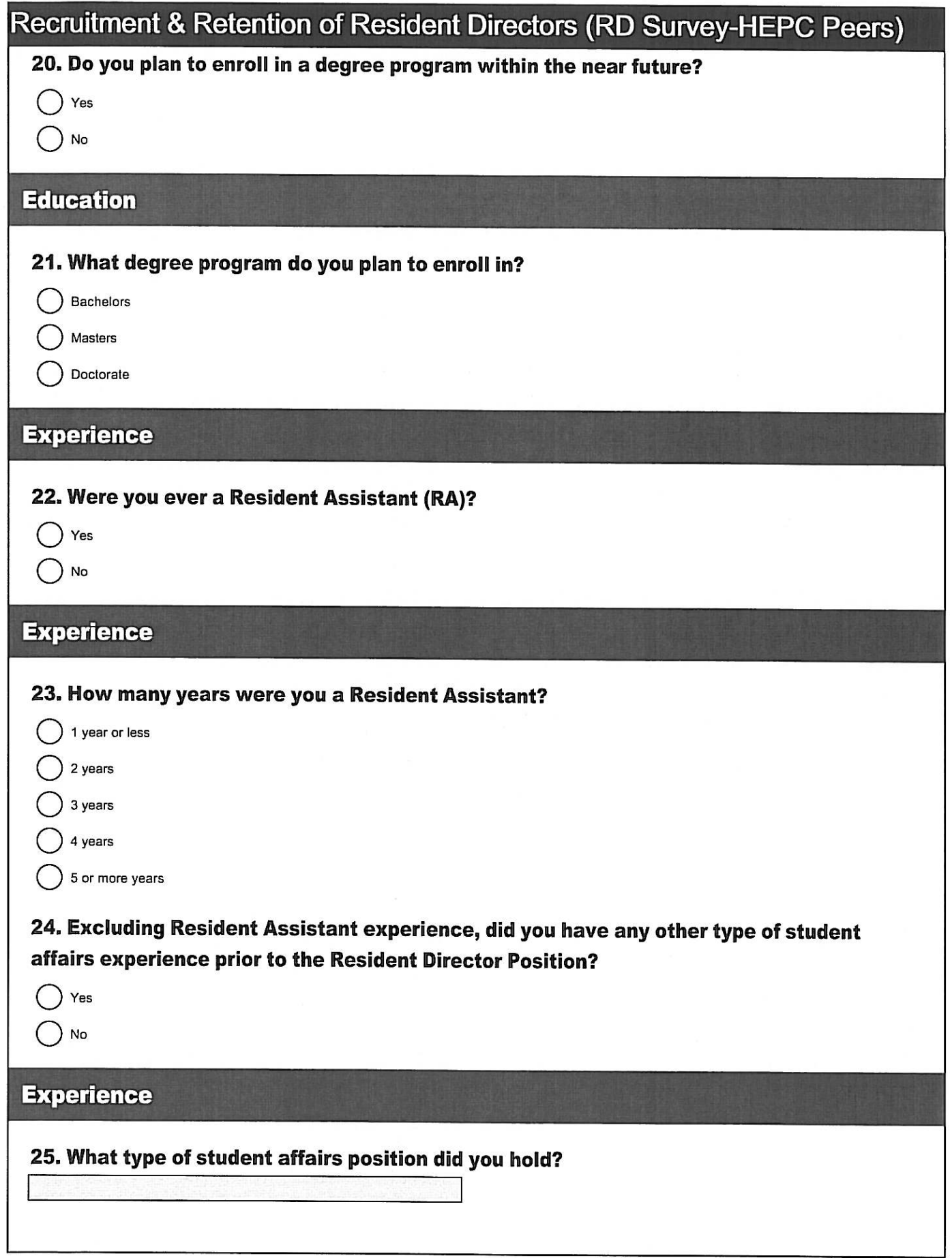


Recruitment \& Retention of Resident Directors (RD Survey-HEPC Peers)

26. How many years experience in student affairs did you have?

1 year or less

2 years

3 years

4 years

5 years or more

Training Information

27. How long before the start of the academic year, did you assume your official duties as a Resident Director?
60 days prior to the academic year
30 days prior to the academic year
15 days prior to the academic year
Less than 15 days prior to the academic year
After the academic year began

28. During your first year as a Resident Director, were you provided with formal training BEFORE the residence halls opened up?

$\bigcirc$ Yes

No

Training Information

29. How long did your initial training last?

1 day or less

2-3 days

4-6 days

1 week

More than 1 week 
Recruitment \& Retention of Resident Directors (RD Survey-HEPC Peers)

30. What topics were covered? (check all that apply)

$\square$ Daily Hall Operations
$\square$ Programming
$\square$ Supervision
$\square$ Counseling/Mentoring
$\square$ Student Conduct
$\square$ Facilities Management

$\square$ Safety and Security

$\square$ Crisis Management

$\square$ First Year Instruction of Course

$\square$ Student Development

$\square$ Budget

Other (please specify)

31. How valuable did you feel this training was?

Extremely Valuable

$\bigcirc$ very Valuable

Somewhat Valuable

Rarely valuable

$\bigcirc$ Not Valuable

\section{Training}

32. Please comment on why you felt training was not valuable.

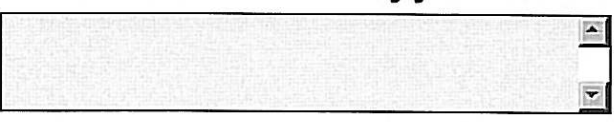

33. During your first year as a Resident Director, were you provided with any formal training AFTER the residence halls opened?

$\bigcirc$ Yes

No

Tteining Information 


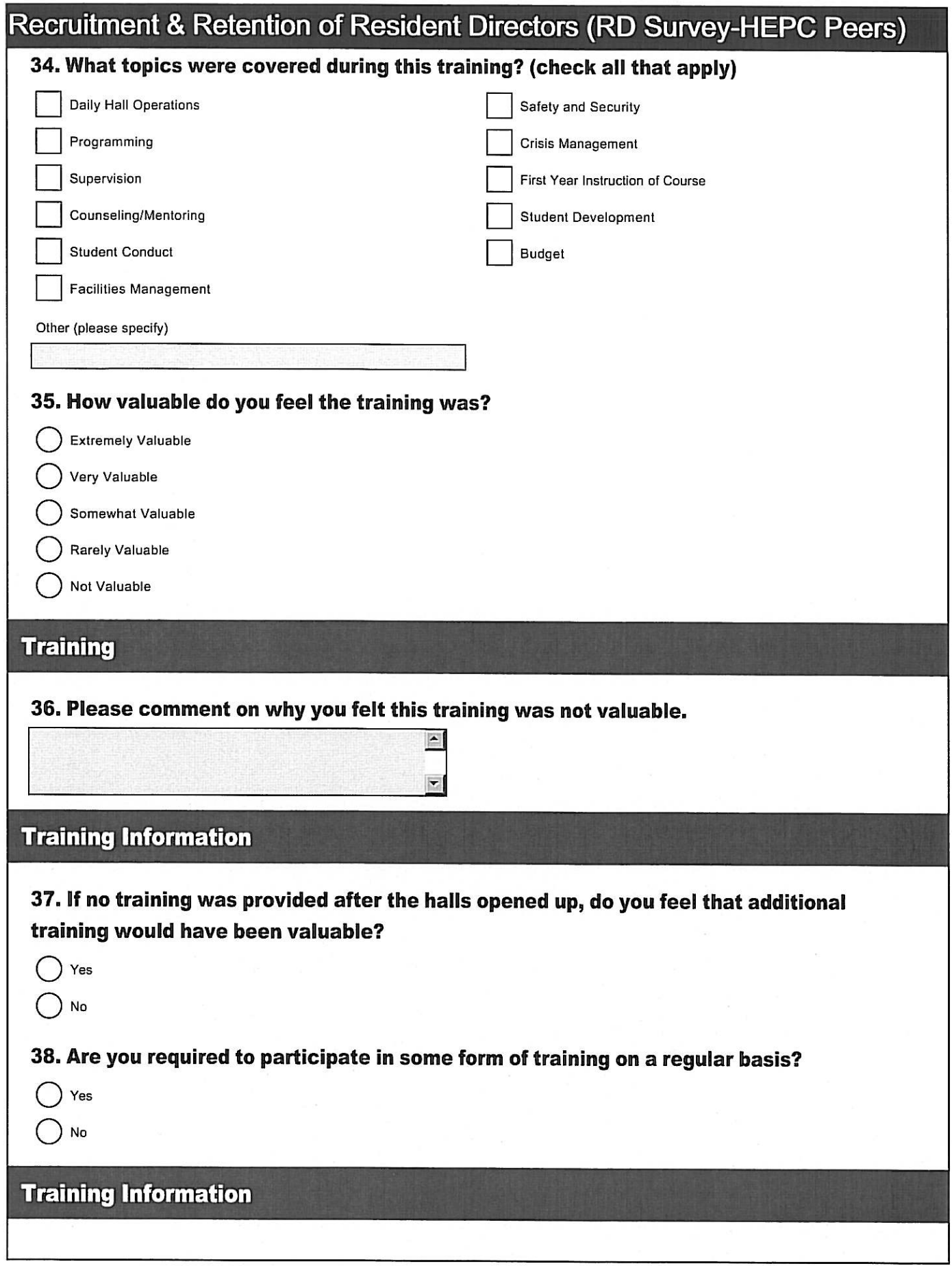




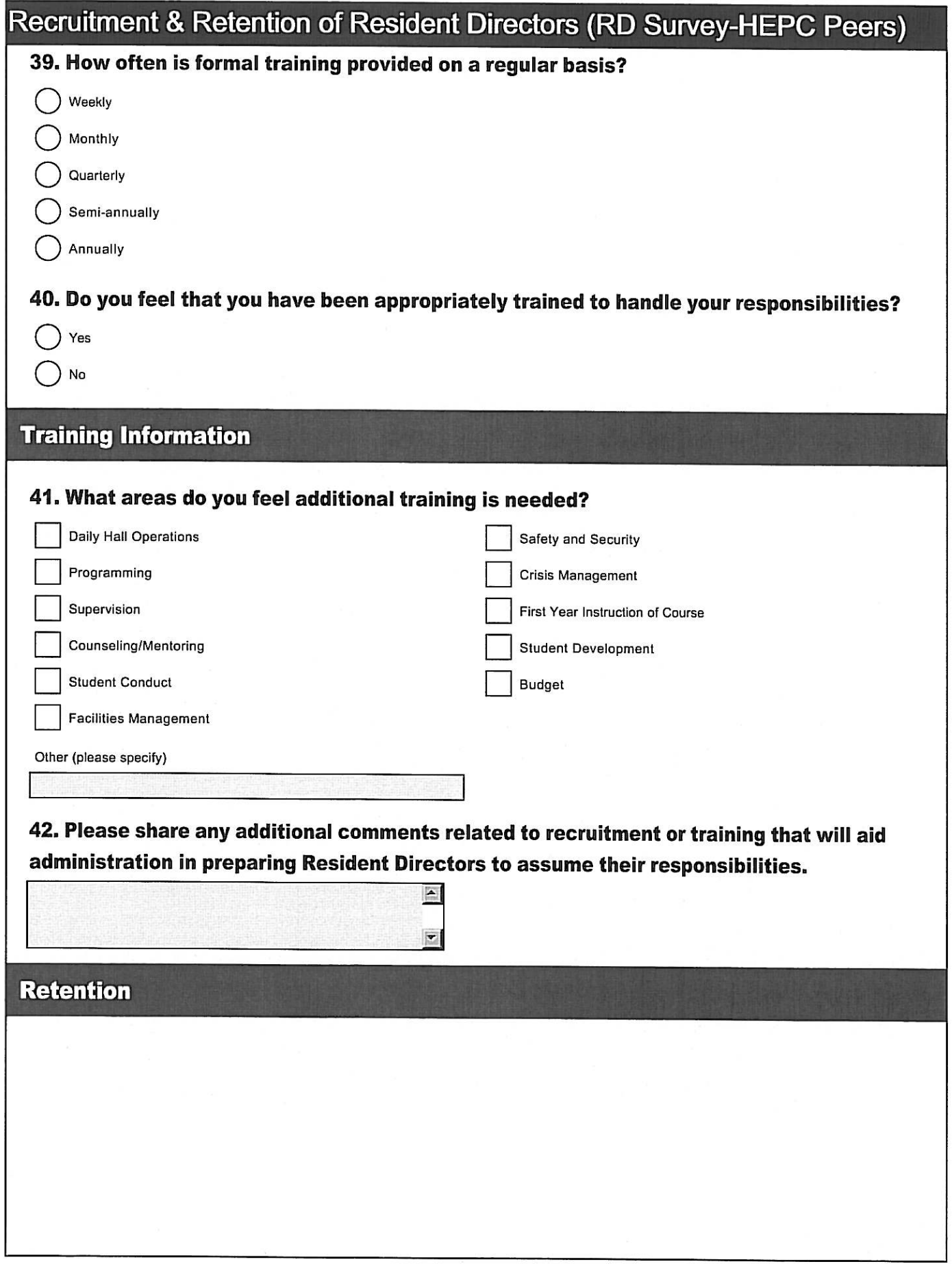


Recruitment \& Retention of Resident Directors (RD Survey-HEPC Peers)

43. How likely are you to continue at your current institution as a Resident Director next year?

$\bigcirc$ Highly Likely

Somewhat Likely

Neutral or Unsure

$\bigcirc$ Somewhat Unlikely

Highly Unlikely

44. If you plan to remain as an Resident Director next year, how many years do you anticipate remaining in the Resident Director position at your current institution?

1 year or less

2 years

3 years

4 years

5 years or more

$\bigcirc$ unsure

45. Once you leave your current institution, how likely are you to be an Resident Director at another institution?
$\bigcirc$ Highly Likely
somewhat Likely
Neutral or Unsure
somewhat Unlikely
$\bigcirc$ Highly Unlikely 


\section{Recruitment \& Retention of Resident Directors (RD Survey-HEPC Peers)}

46. How likely are you to leave the Resident Director position based on the following reasons:

Don't want to live-in
Feel Unappreciated
Another Position
$\begin{aligned} & \text { Pursuit of Educational } \\ & \text { Opportunities } \\ & \text { Job Burnout } \\ & \text { Inadequate Benefits } \\ & \text { Inadequate Salary } \\ & \text { Don't get along with } \\ & \text { Administration }\end{aligned}$

47. To what degree do you feel respected by the department administration?
Highly Respected
Respected
Somewhat Repected
Rarely Respected
Never Respected

48. To what degree do you feel respected by the university administration?

Highly Respected

$\bigcirc$ Respected

Somewhat Repected

Rarely Respected

Never Respected

49. To what degree do you feel you are a valued staff member?
Extremely Valued
$\bigcirc$ very Valued
Somewhat valued
Rarely Valued
$\bigcirc$ Never Valued

\section{Retemiton}


Recruitment \& Retention of Resident Directors (RD Survey-HEPC Peers)

50. How often are you provided with performance feedback?

Very Often

Often

Occassionally

Rarely

Never

51. How often are you able to operate autonomously?

$\bigcirc$ very Often

Often

Occassionally

Rarely

Never

52. How often are you encouraged to develop professionally?

very Often

often

Occassionally

Rarely

Never

Retention

53. How often do you participate in professional development opportunities?

very Often

Often

Occassionally

Rarely

Never

Retention 


\section{Recruitment \& Retention of Resident Directors (RD Survey-HEPC Peers)}

54. What type of professional development opportunities do you participate in? (check all that apply)

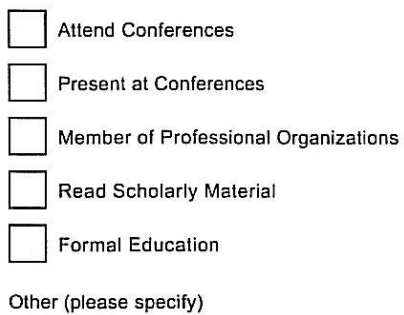

Other (please specify)

\section{Retention}

55. If you have not participated in professional development opportunties, what are your reasons for not participating? (check all that apply)

$\square$ Unsupported by Administration

Budget Constraints

$\square$ Time Constraints

Not Interested

Other (please specify)

\section{Retention}

56. Do you have someone you consider to be a professional mentor?

Yes

No

\section{Retention}




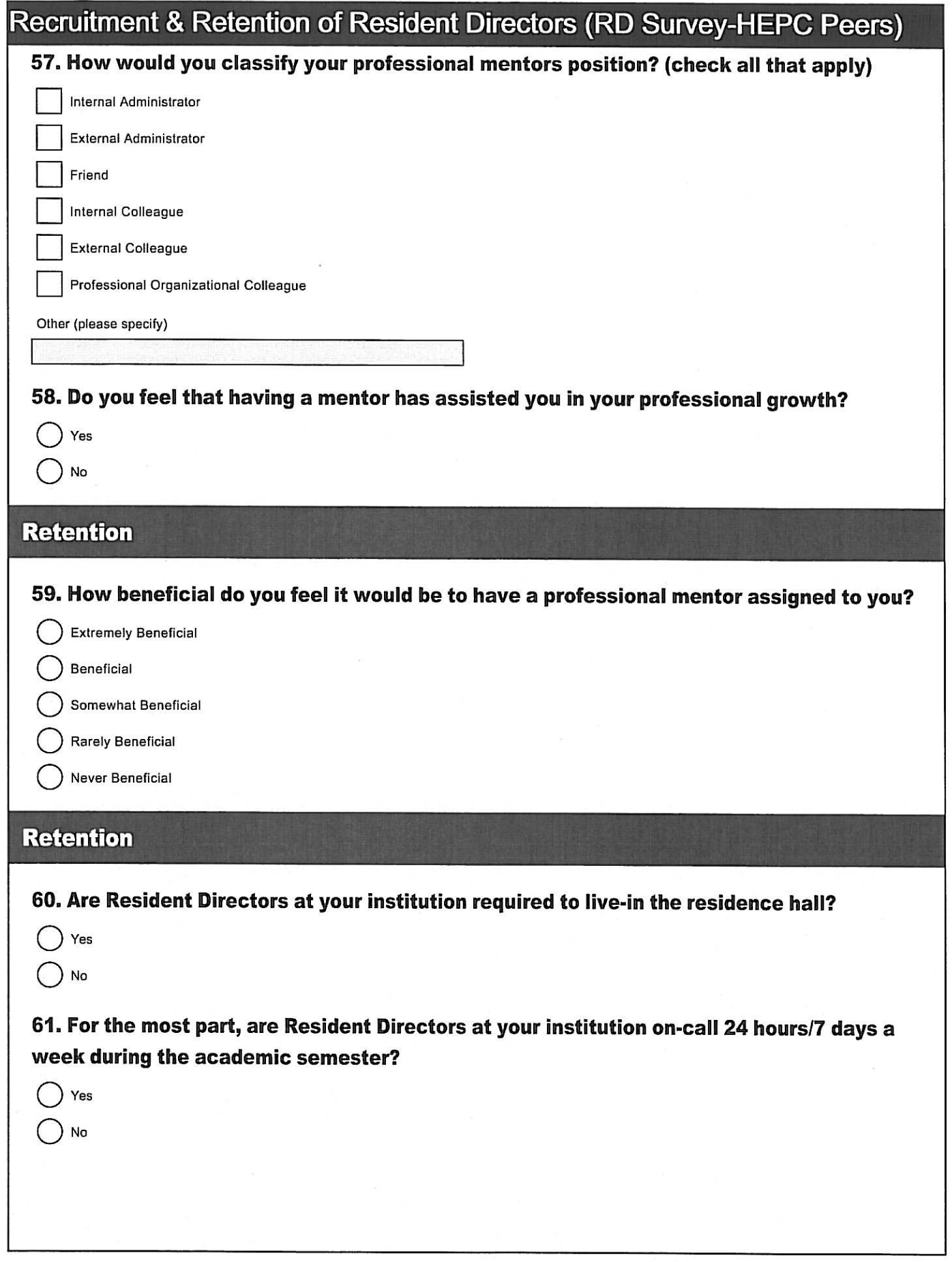




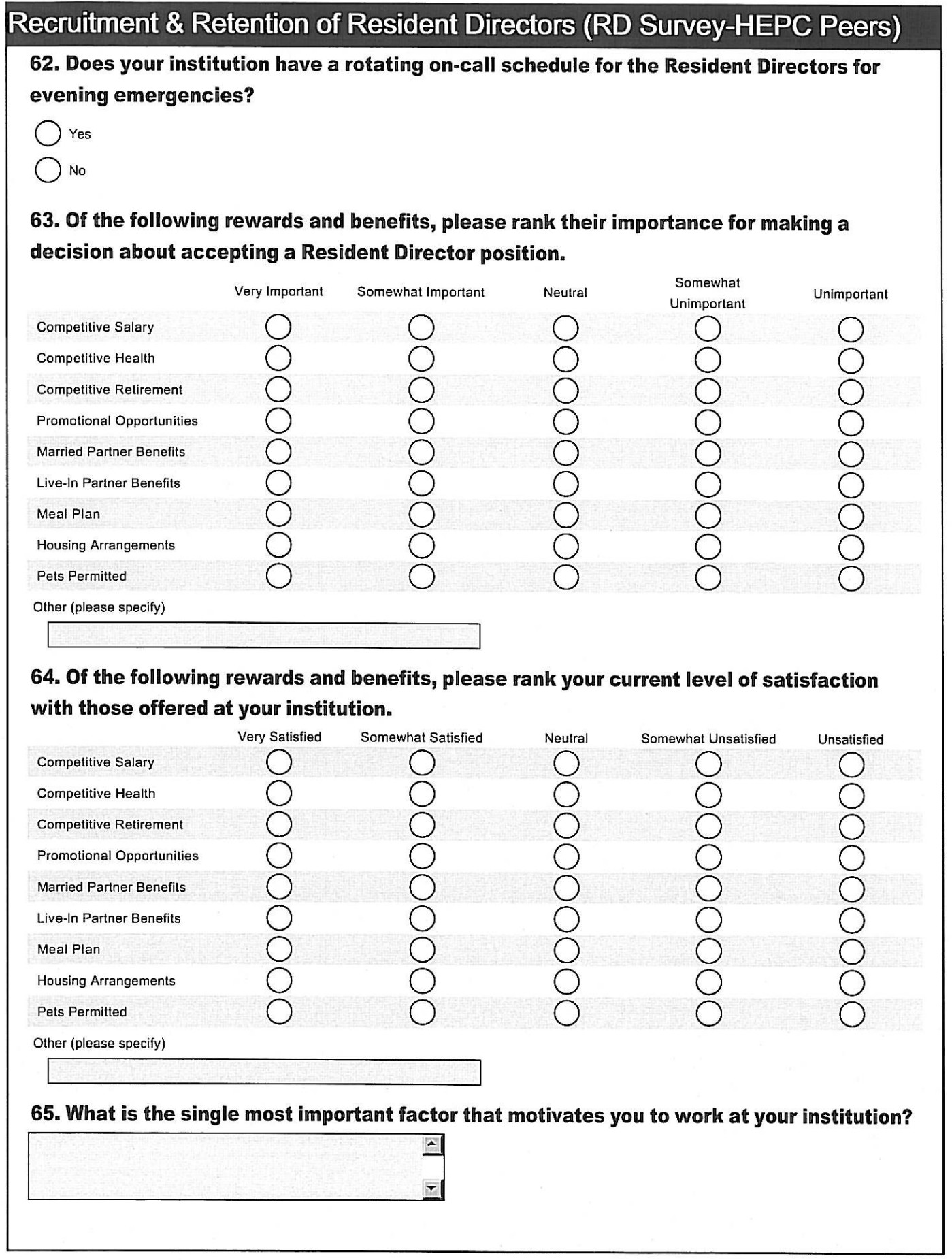


Recruitment \& Retention of Resident Directors (RD Survey-HEPC Peers)

66. Please share any additional comments that would aid administration in their efforts to retain $\mathbb{R}$ Resident Directors.

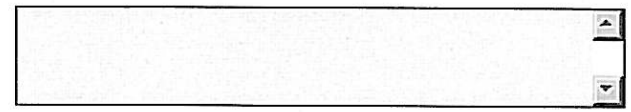


APPENDIX B Survey Regarding Best Practices for the Recruitment and Retention of Resident Directors submitted to Residence Life Administrators 


\section{Recruitment \& Retention of Resident Directors (HEPC Admin Survey)}

Demographics

\section{What is your gender?}

Male

Female

Transgender

\section{What is your age?}
Under 30
30.35
(36-40
$\bigcirc_{41.45}$
Over 45

\section{What is your ethnic affiliation?}
African American/Black
Asian American/Pacific Islander
White/Caucasian/European American
Hispanic American/Lation/Chicano
MultiRacial
Native American/Tribal Affiliation
Other or Prefer Not to Answer

\section{What is your official title?}




\section{Recruitment \& Retention of Resident Directors (HEPC Admin Survey)}

\section{Background Information}

Note: Throughout this survey the term Resident Director will be utlized in reference to positions such as Residence Hall Coordinator, Area Advisor, Complex Director, etc.

\section{How many years have you been a Residence Life Administrator?}
1 year or less
2 years
3 years
4 years
5 years or more

6. How many years have you been a Residence Life Administrator at your current institution?
1 year or less
2 years
3 years
4 years
5 years or more

7. What is the academic class rank of students living in the residence halls you have oncampus?
Mostly freshmen
Mostly upper-class
Mix of freshmen and upper-class

8. What is the gender of students living in the residence halls you have on-campus?
Mostly males
Mostly females
Mix of females and males 


\section{Recruitment \& Retention of Resident Directors (HEPC Admin Survey)}

Background Information

9. What of the following job duties are Resident Directors at your institution responsible for? (please check all that apply)

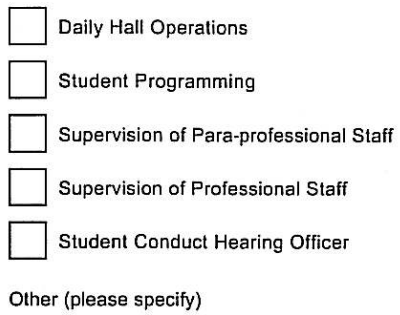

Other (please specify)

10. How many Resident Assistants (RAs) do Resident Directors at your institution typically supervise?

$\bigcirc$ Less than 7 RAs

8-15 RAs

16-20 RAS

21.25 RAs

More than 25

$\bigcirc$ varies too much to categorize 


\section{Recruitment \& Retention of Resident Directors (HEPC Admin Survey)}

\section{Training}

Please respond to the following questions based on your perception, knowledge and experience as a Residence Life Administrator.

11. When Resident Directors first assume their duties, overall, how prepared do you feel they are to assume these duties?
$\bigcirc$ very Well Prepared
Well Prepared
$\bigcirc$ Adequately Prepared
Poorly Prepared
Very Poorly Prepared

12. How prepared do you feel Resident Directors are to handle their duties after being on the job at least one year?
$\bigcirc$ very Well Prepared
Well Prepared
$\bigcirc$ Adequately Prepared
$\bigcirc$ Poorly Prepared
$\bigcirc$ Very Poorly Prepared

13. How important do you feel the following skills are in preparing Resident Directors to assume their duties?

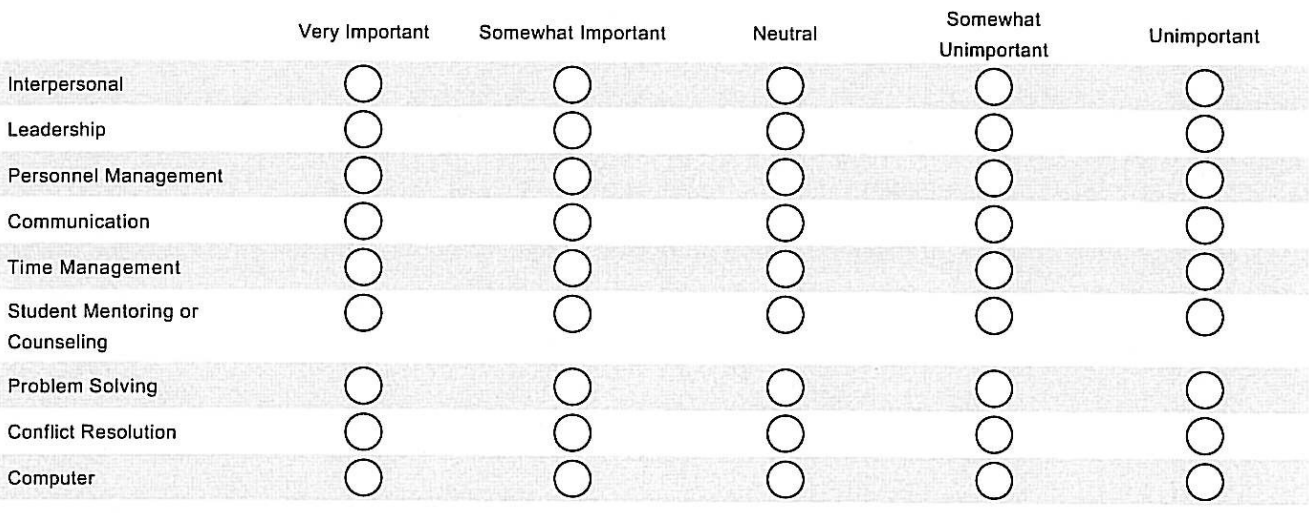

14. Please list any other skill(s) not listed above that you believe to be "Very Important" or "Important" for Resident Director to possess. 


\section{Recruitiment \& Retention of Resident Directors (HEPC Admin Survey)}

\section{Education}

15. What is the minimum level of education required to be a Resident Director at your institution?

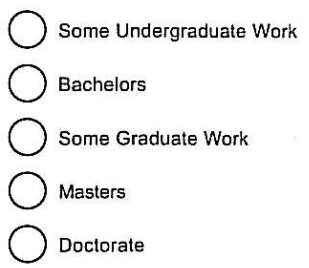

16. How often are you able to hire candidates who meet the minimum educational requirements?
Always
very Often
often
Sometimes
Rarely

17. Do you require your Resident Director candidates to have Resident Assistant experience?

$O$ yes No 


\section{Recruitment \& Retention of Resident Directors (HEPC Admin Survey)}

Experience

18. How many years of Resident Assistant experience do you require your Resident Director candidates to have?
1 year or less
2 years
3 years
4 years
5 or more years

19. Do you require your Resident Director candidates to have any other type of student affairs experience?

$\bigcirc$ Yes

No 


\section{Recruitment \& Retention of Resident Directors (HEPC Admin Survey)}

Experience

20. How many years of student affairs experience do you require?

1 year or less

2 years

3 years

4 years

5 years or more

21. How often are you able to hire highly qualified Resident Director candidates?

Always

very Often

Often

Sometimes

Rarely

22. How do you advertise/recruit for vacant Resident Director positions? (Check all that apply)
$\square$ Institutional Posting
$\square$ Recruitment Fairs
National Advertisements
Professional Organization Postings

Other (please specify) 
Recruitment \& Retention of Resident Directors (HEPC Admin Survey)

Training

23. How long before the start of the academic year do your newly hired Resident Directors assume their official duties?
60 days prior to the academic year
30 days prior to the academic year
(15 days prior to the academic year
Less than 15 days prior to the academic year

24. Does your department provide formal training for first year Resident Directors BEFORE the residence halls open?

Yes

No 


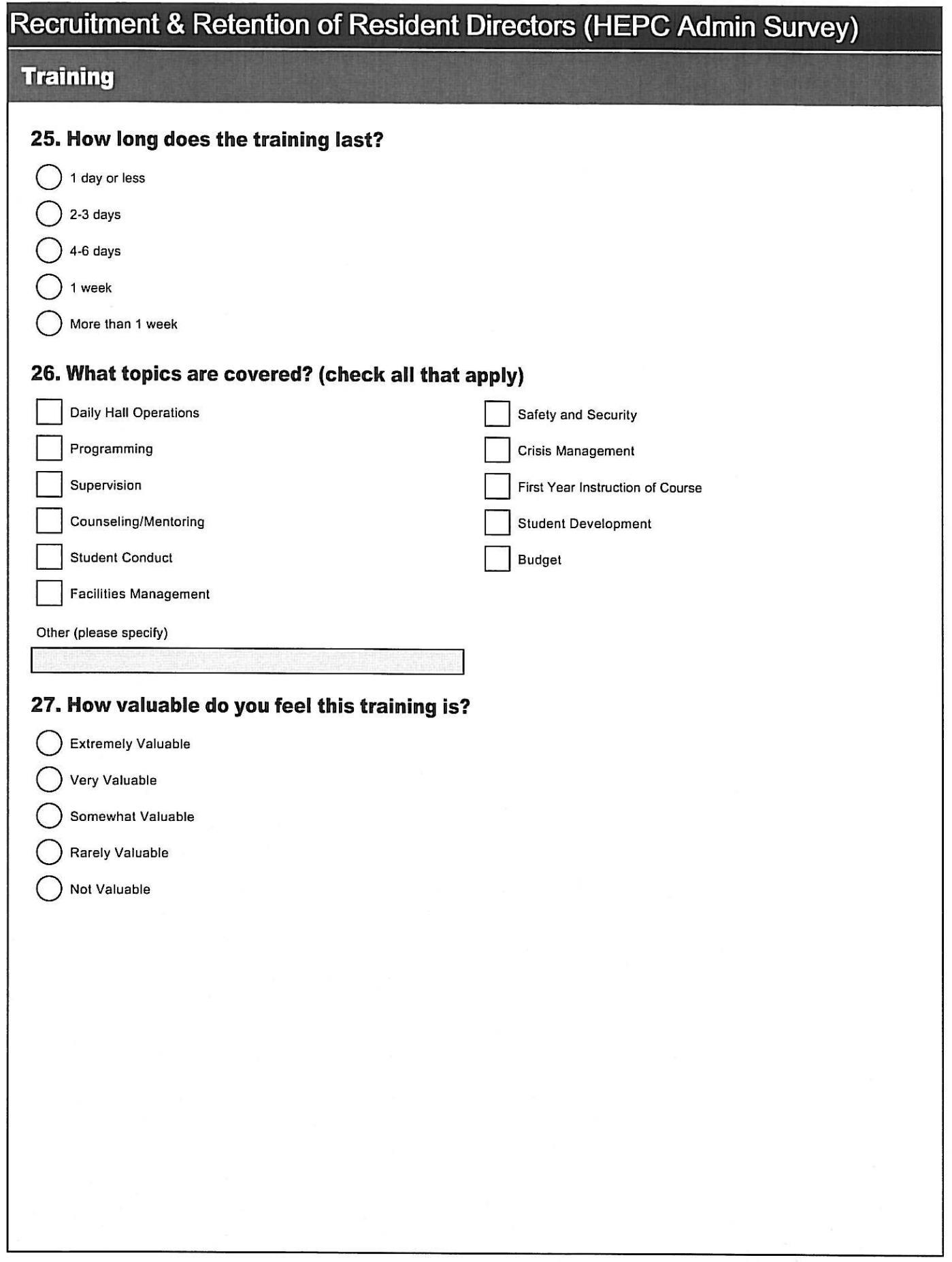




\section{Recruitment \& Retention of Resident Directors (HEPC Admin Survey)}

Training

28. Please comment on why you felt training was not valuable.

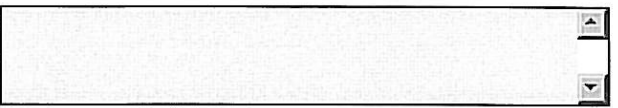

29. Does your department provide any additional formal training for first year Resident Directors AFTER the residence halls open?

$\bigcirc$ Yes

No 


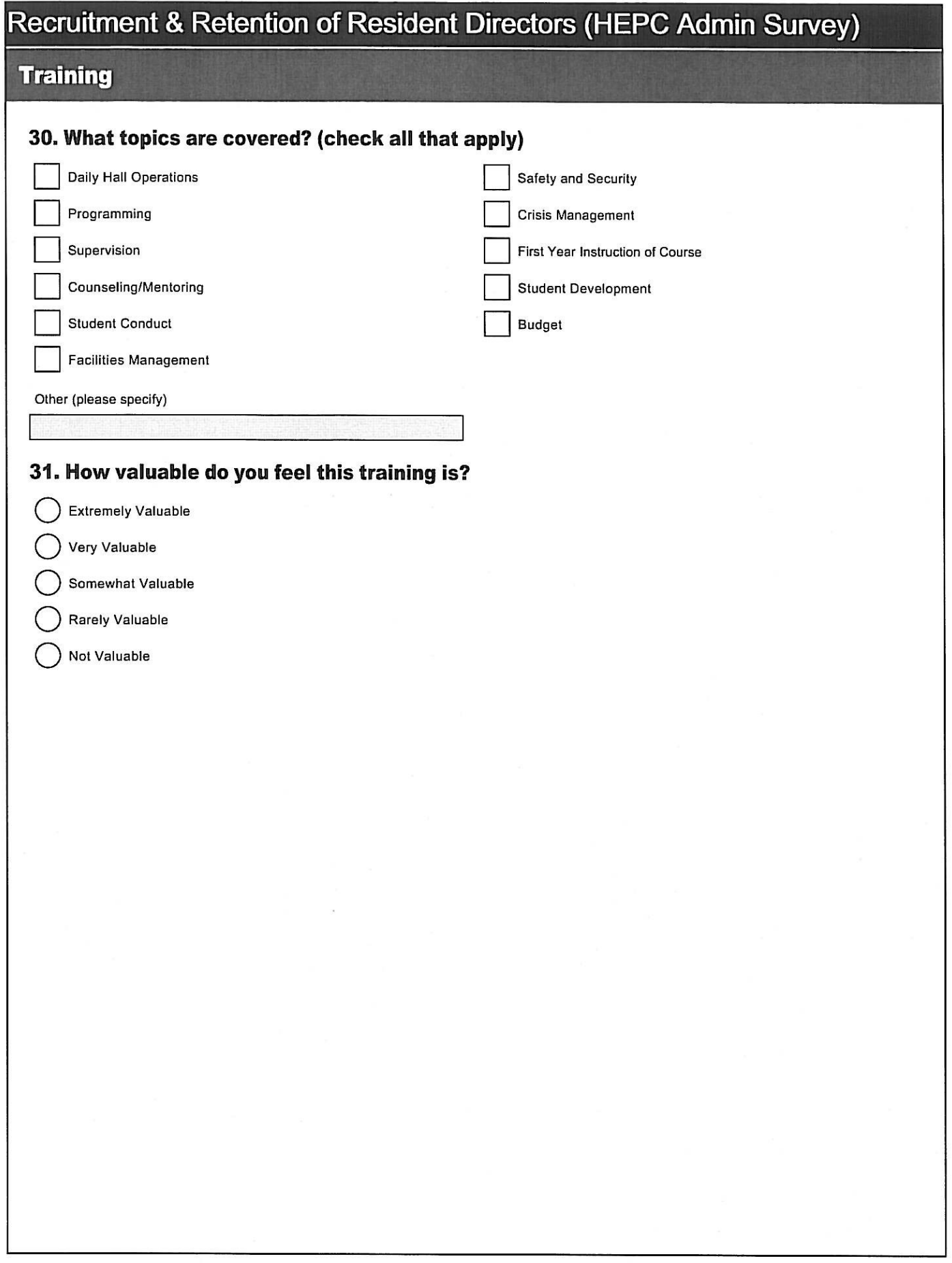


Recruitment \& Retention of Resident Directors (HEPC Admin Survey)

Tralinitis

32. Please comment on why you feel that the training was not valuable.

\begin{tabular}{|r|r|r|}
\hline & \\
\hline
\end{tabular}

33. Are Resident Directors at your institution required to participate in some form of formal training on a regular basis?

$\bigcirc$ Yes

No 


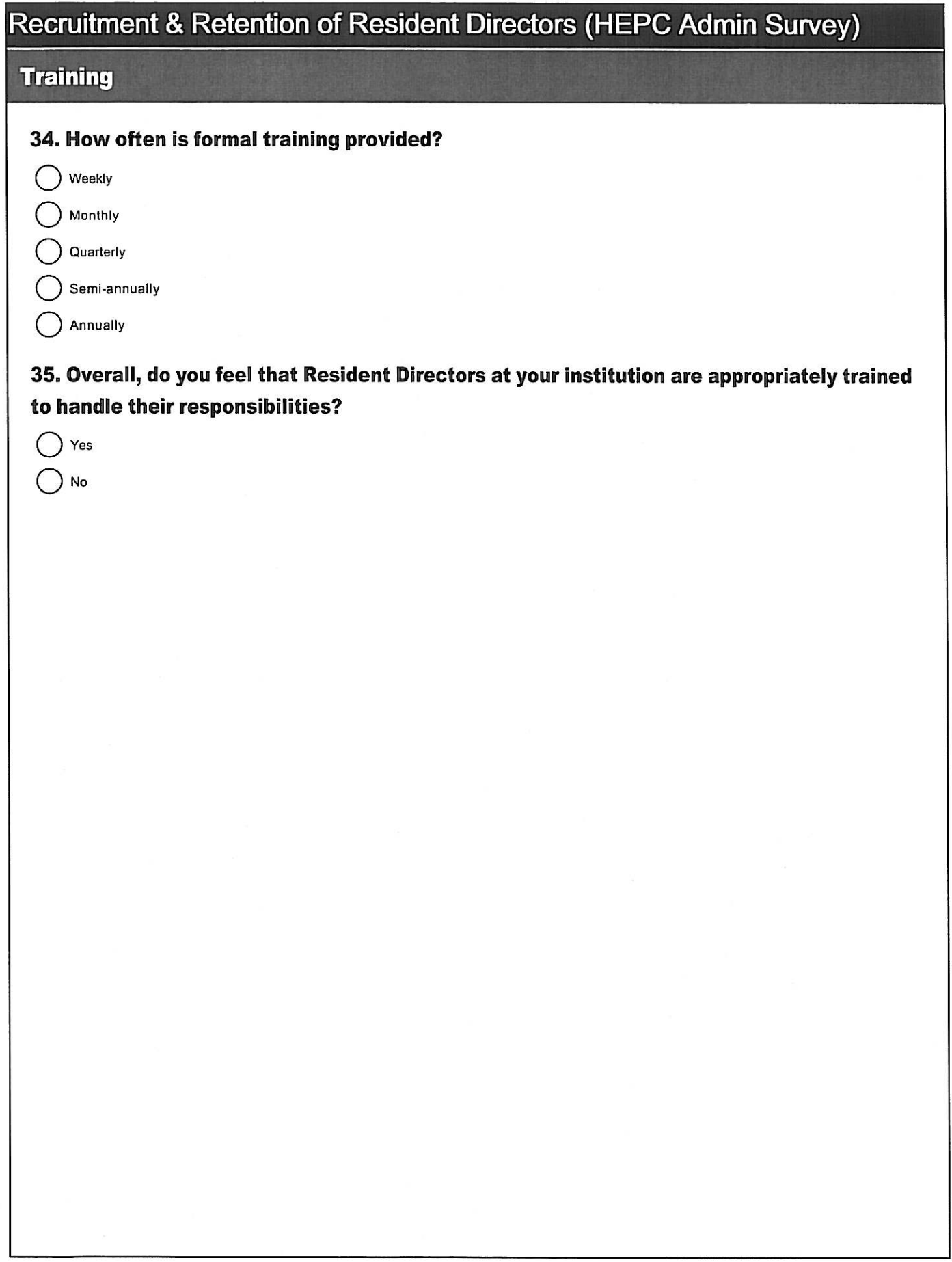




\section{Recruitment \& Retention of Resident Directors (HEPC Admin Survey) \\ Training}

36. In what areas do you feel additional training is needed?

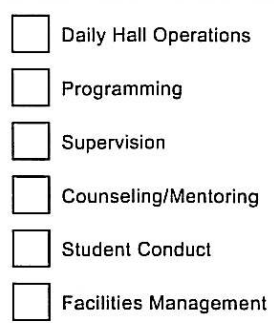

$\square$ Safety and Security

$\square$ Crisis Management

$\square$ First Year Instruction of Course

$\square$ Student Development

$\square$ Budget

Other (please specify)

37. Please share any additional comments related to recruitment or training that will aid administrators in preparing Resident Directors to assume their responsibilities.

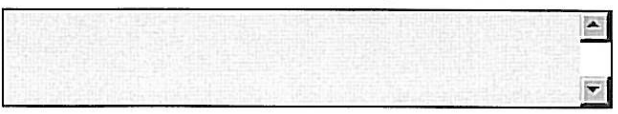




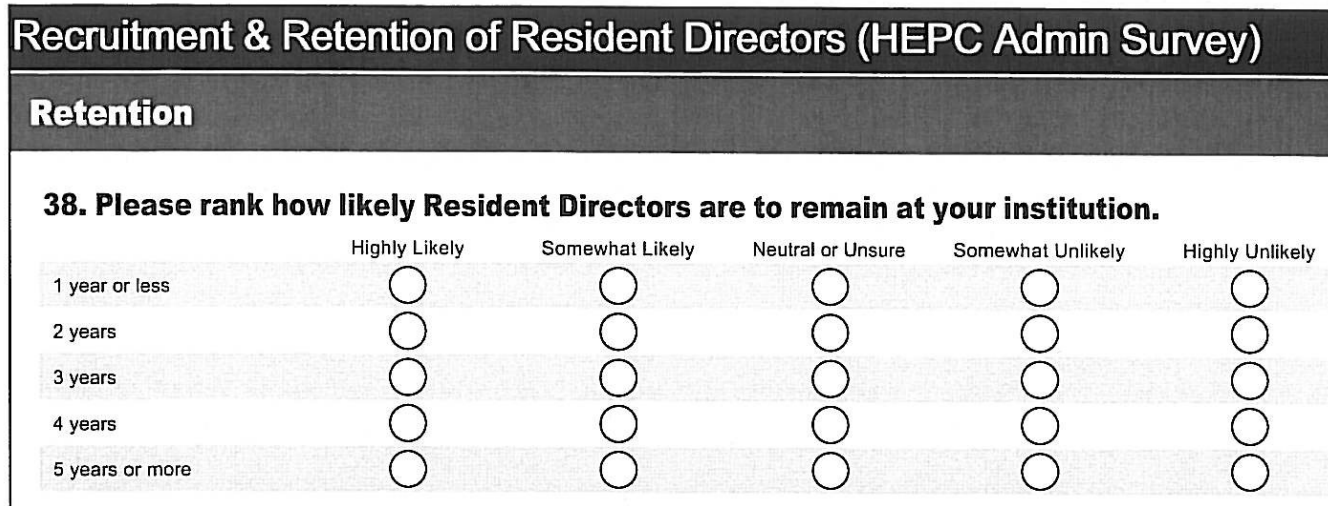

39. How many full-time professional Resident Directors does your institution have on staff?

40. How many of the Resident Directors on staff have the following years of experience at your institution? (please enter numerical value for each category)

1 Year or Less

2 Years

3 Years

4 Years

5 or More Years

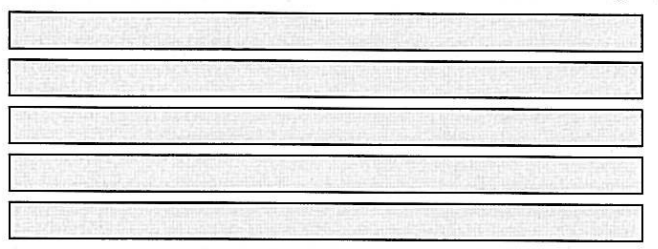

41. What do you feel are the most common reason(s) for a Resident Director to leave their position?

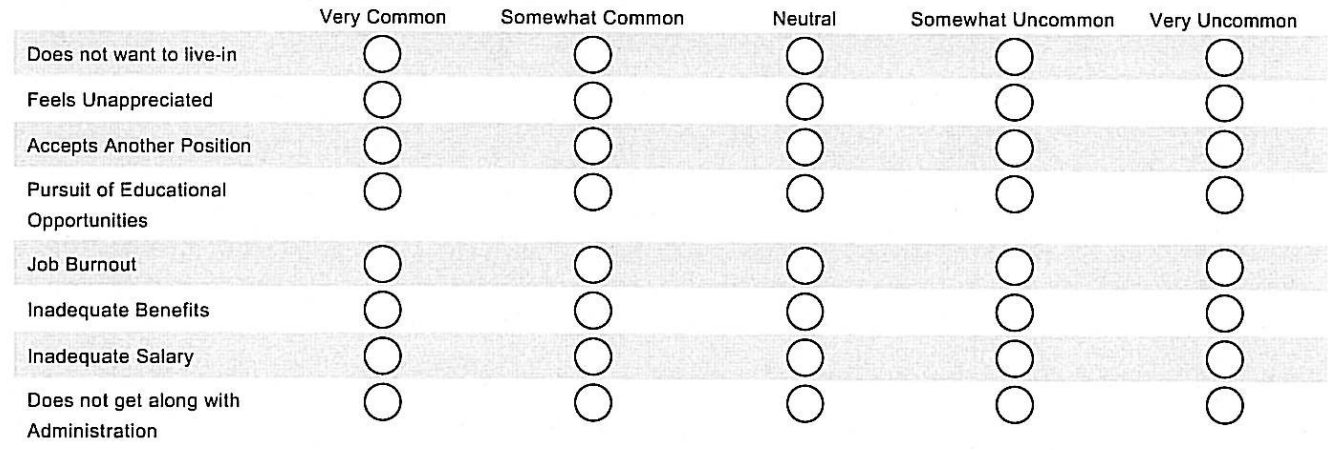


Recruitment \& Retention of Resident Directors (HEPC Admin Survey)

42. To what degree are Resident Directors respected by department administration?

Highly Respecled

$\bigcirc$ Respected

Somewhat Respected

Rarely Respected

$\bigcirc$ Never Respected

43. To what degree are Resident Directors respected by university administration?

$\bigcirc$ Highly Respected

$\bigcirc$ Respected

Somewhat Respected

$\bigcirc$ Rarely Respected

$\bigcirc$ Never Respected

44. To what degree do you believe Resident Directors are valued staff members?

$\bigcirc$ Extremely Valued

$\bigcirc$ Very Valued

$\bigcirc$ somewhat valued

$\bigcirc$ Rarely valued

$\bigcirc$ Never Valued

45. How often does your department provide performance feedback?

Very Often

often

$\bigcirc$ Occassionally

Rarely

Never 
Recruitment \& Retention of Resident Directors (HEPC Admin Survey)

Reterition

46. How often does your department allow Resident Directors to operate autonomously?

very often

often

Occassionally

Rarely

Never

47. How often does your department encourage Resident Directors to take advantage of professional development opportunities?

$\bigcirc$ very Often

often

Occassionally

Rarely

$\bigcirc$ Never 


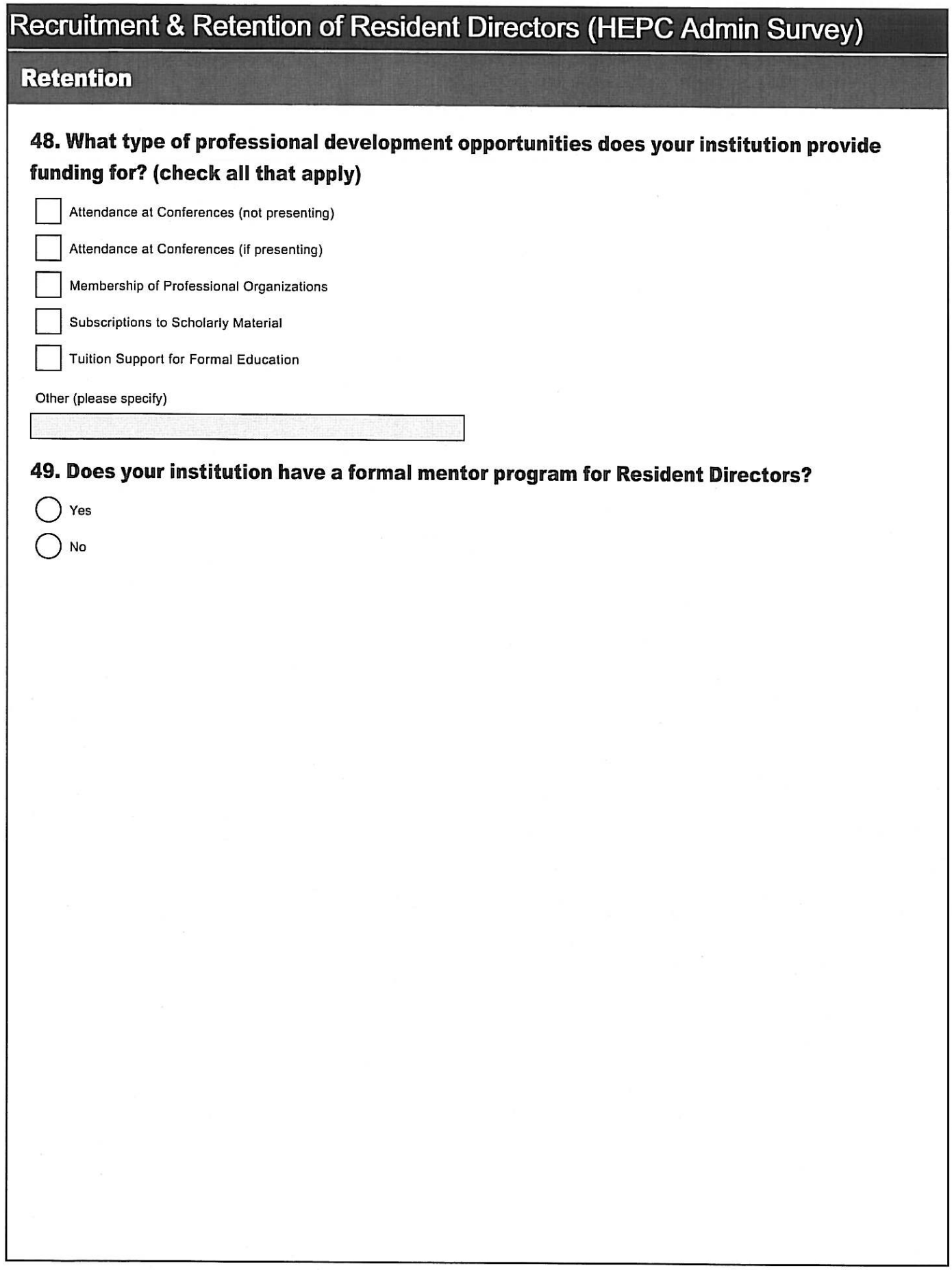




\section{Recruitment \& Retention of Resident Directors (HEPC Admin Survey)}

Retention

50. Who are your formal mentors? (check all that apply)

$\square$ Internal Administrators

External Administrators

$\square$ Friends

$\square$ Internal Colleagues

$\square$ External Colleagues

Professional Organizational Colleagues

Other (please specify)

51. Do you feel that having professional mentors is beneficial to the Resident Directors' professional growth?

Yes

No 
Recruitment \& Retention of Resident Directors (HEPC Admin Survey)

Retention

52. How beneficial is it for Resident Directors to have a professional mentor assigned to them?

$\bigcirc$ Extremely Beneficial
Beneficial
Somewhat Beneficial
Rarely Beneficial
Never Beneficial

53. Are Resident Directors at your institution required to live-in the residence halls?

Yes

No

54. For the most part, are the Resident Directors on-call 24 hours/7 days a week during the academic semester?

$\bigcirc$ Yes

No

55. Does your institution have a rotating on-call schedule for the Resident Directors for evening emergencies?

Yes

No 


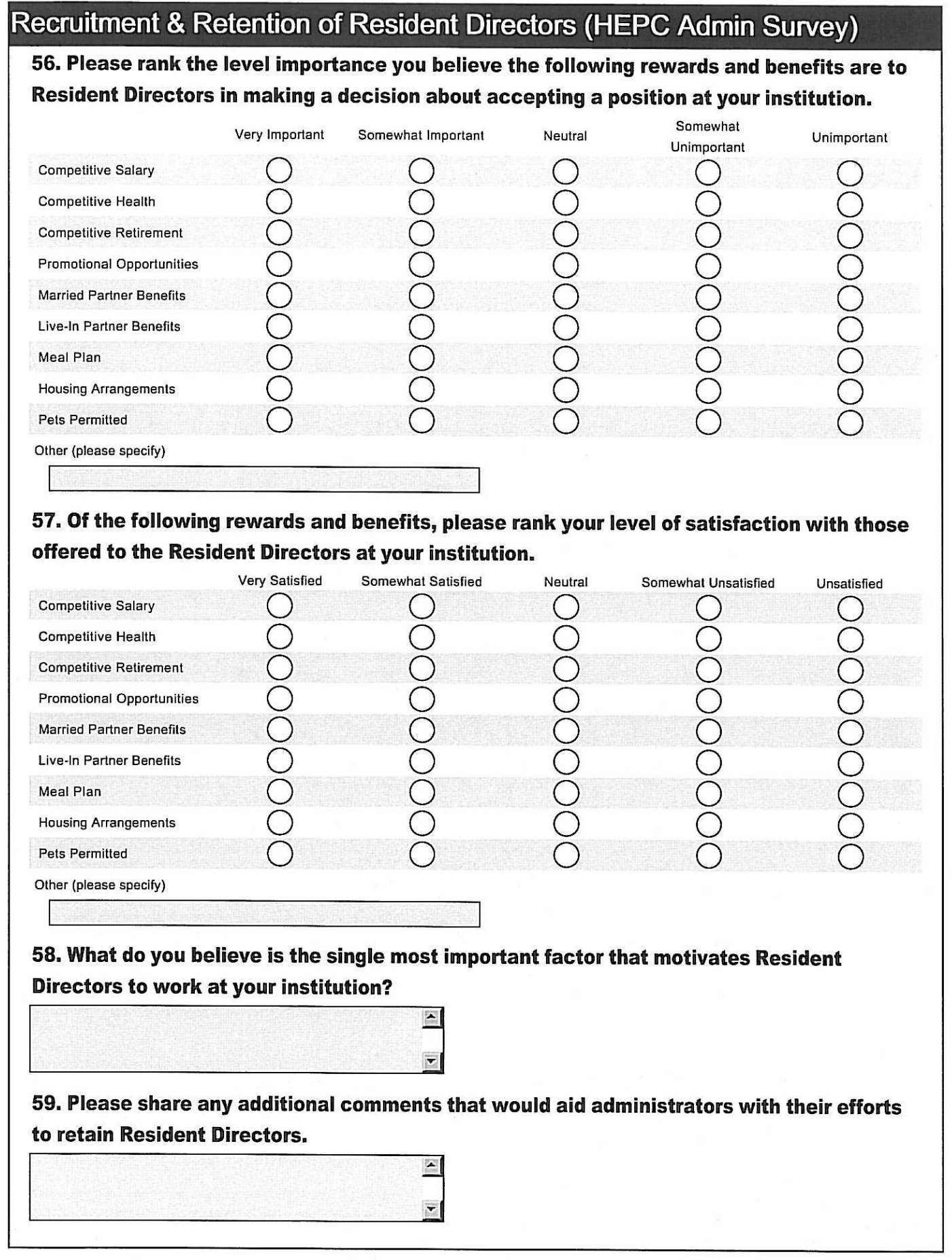




\section{APPENDIX C}

Pilot Participant Invitation Letter

(West Virginia University Letterhead)

(Date)

(Name)

(Institution)

(Street)

(City, State, Zip)

\section{Dear (Name):}

I am a doctoral student in the Educational Leadership Program at West Virginia University in Morgantown, West Virginia. I am currently working on my dissertation research study entitled, A Study of Best Practices for the Recruitment and Retention of Residence Hall Directors. The purpose of this letter is to request your participation in this research study.

The purpose of my study is to determine the best practices needed in assuring that newly hired, entry-level residence hall directors are adequately prepared to assume and retain their leadership position. It is hoped that this study will educate residence life administrators about appropriate hiring requirements, necessary training techniques, and the level of on-going support needed to retain high-quality residence hall directors. It is also hoped that this research will educate other university administrators about the importance of this professional population by examining factors associated with their recruitment and retention.

I plan to conduct a pilot study with 12 residence hall coordinators and two residence life administrators. If you accept this invitation to participate in the pilot study, you will be asked to complete an online questionnaire that will take about 15 minutes to complete and participate in a brief follow-up interview. Feedback received from the pilot study will assist in enhancing the quality of the instrument and aid with the administration process. Following the pilot study, modifications will be made so that additional research can be conducted. I will then survey resident hall directors and residence life administrators at 22 institutions; 11 identified by ACUHO-I Commissioned Research (Ellett, 2008) as having best practices in the recruitment and retention of resident directors and 11 selected from WVU's Higher Education Policy Commission peer institutions.

Your involvement in this study will remain confidential. The information collected from respondents will be aggregated. Your name and any other identifiable information will not be released in the reported results. All responses will remain confidential. You must be 18 years or older to participate, and your participation is entirely voluntary. In addition, you can skip questions or exit the questionnaire at any time. West Virginia University's Institutional Review Board for the Protection of Human Subjects acknowledgement of this project is on file. 
Please note that there are no known risks or expected risks for participating in this study. There are no known direct benefits for participating in the study; however, the knowledge gained from this study may benefit residence life administrators and residence hall directors with retention and recruitment efforts.

Thank you in advance for your time.

Sincerely,

Patricia L. Cendana

Doctoral Student

West Virginia University 


\title{
APPENDIX D
}

\section{Participant Invitation Letter}

\section{West VirginiaUniversity}

\author{
Student Affairs
}

October 15, 2011

Dear Resident Director:

I am a doctoral student in the Educational Leadership Program at West Virginia University in Morgantown, West Virginia. I am currently working on my dissertation research study entitled, A Study of Best Practices for the Recruitment and Retention of Residence Hall Directors. The purpose of this letter is to request your participation in this research study. You have been selected because of your experience and expertise within this field. As someone who works in the residence life field, I understand the demanding nature of your position and know your time is very valuable. It is hoped that this survey will aid others in understanding how valuable your time is. Your participation in this project is greatly appreciated.

The purpose of my study is to determine the best practices needed in assuring that resident directors are adequately prepared to assume and retain their leadership position. It is hoped that this study will educate residence life administrators about appropriate hiring requirements, necessary training techniques, and the level of on-going support needed to retain high-quality resident directors. It is also hoped that this research will educate other university administrators about the importance of this professional population by examining factors associated with their recruitment and retention.

As part of this study, you will be asked to complete an online survey that will take approximately 15 minutes of your time. If you agree to participate in the pilot study, please $\log$ on to the SurveyMonkey ${ }^{\mathrm{TM}}$ website https://www.surveymonkey.com/s/residentdirectors 1 to complete the survey. By clicking on the following link, you will be agreeing to participate in this study and will be automatically directed to the survey instrument. Because of the nature of my survey, I ask that you do not forward this link to others to complete.

Your involvement in this study will remain confidential. The information collected from respondents will be aggregated. Your name and any other identifiable information will not be released in the reported results. All responses will remain confidential. You must be 18 years or older to participate, and your participation is entirely voluntary. In addition, you can skip questions or exit the questionnaire at any time. West Virginia University's Institutional Review Board for the Protection of Human Subjects acknowledgement of this project is on file.

Please note that there are no known risks or expected risks for participating in this study. There are no known direct benefits for participating in the study; however, the knowledge gained from this study may benefit residence life administrators and resident directors with retention and recruitment efforts.

I hope that you will share your experience and expertise by participating in this study. If you have any questions about this research project, please feel free to contact the researcher Patricia Cendana at 304-2934686 or via email at tlcendana@mail.wvu.edu. Thank you in advance for your time.

Sincerely,

Patricia L. Cendana

Doctoral Student

West Virginia University

Residential Education

Evansdale Central Office

M70 Brooke Tower

Phone: 304-293-4686

Fax: 304-293-2427
PO Box 6430

Morgantown, WV 26506-6430
Elizabeth Jones, Ph.D

Doctoral Chair

West Virginia University 